\title{
FABIANA DA CONCEIÇÃO LEITE
}

\section{COMPORTAMENTO MECÂNICO DE AGREGADO RECICLADO DE RESÍDUO SÓLIDO DA CONSTRUÇÃO CIVIL EM CAMADAS DE BASE E SUB-BASE DE PAVIMENTOS}

\author{
Dissertação apresentada à Escola \\ Politécnica da Universidade de São Paulo \\ para obtenção do Título de Mestre em \\ Engenharia de Transportes.
}

São Paulo 


\section{FABIANA DA CONCEIÇÃO LEITE}

\section{COMPORTAMENTO MECÂNICO DE AGREGADO RECICLADO DE RESÍDUO SÓLIDO DA CONSTRUÇÃO CIVIL EM CAMADAS DE BASE E SUB-BASE DE PAVIMENTOS}

Dissertação apresentada à Escola

Politécnica da Universidade de São Paulo para obtenção do Título de Mestre em

Engenharia de Transportes.

Área de Concentração:

Engenharia de Transportes

Orientadora:

Prof $^{\mathrm{a}}$. Dr ${ }^{\mathrm{a}}$.

Liedi Légi Bariani Bernucci 
Este exemplar foi revisado e alterado em relação à versão original, sob responsabilidade única do autor e com a anuência de seu orientador.

São Paulo, 12 de julho de 2007.

Assinatura do autor

Assinatura do orientador

FICHA CATALOGRÁFICA

Leite, Fabiana da Conceição

Comportamento mecânico de agregado reciclado de resíduo sólido da construção civil em camadas de base e sub-base de pavimentos / F.C. Leite. -- São Paulo, 2007.

$185 \mathrm{p}$.

Dissertação (Mestrado) - Escola Politécnica da Universidade de São Paulo. Departamento de Engenharia de Transportes.

1.Infra-estrutura de transportes 2.Pavimentação 3.Reciclagem de resíduos urbanos I.Universidade de São Paulo. Escola Politécnica. Departamento de Engenharia de Transportes II.t. 
Aos meus pais,

Valdeia e Hélio 


\section{AGRADECIMENTOS}

Agradeço primeiramente a Deus, por me dar força e coragem todos os dias.

À minha querida família, pelo amor e apoio incondicionais.

À minha orientadora Profa. Liedi Bernucci, pela amizade, oportunidade, atenção e carinho. Obrigada por sempre acreditar nesta dissertação!

À Coordenadoria do Espaço Físico da Universidade de São Paulo (Coesf), em especial ao Prof. Antonio Massola, que desde o primeiro momento apoiou e incentivou a implantação do pavimento com materiais reciclados na USP Leste.

À Dynatest Engenharia Ltda., em especial ao Eng. Leonardo Preussler, que cedeu gentilmente os operadores e o equipamento Falling Weight Deflectometer.

À Concremat Engenharia e Tecnologia S. A., em especial ao Eng. Paulo Fernando Silva, que cedeu gentilmente fotos e relatórios de acompanhamento da obra.

Ao Prof. Carlos Suzuki e ao Prof. Vanderley John, pelas críticas e sugestões no exame de qualificação.

Ao super Prof. Edson de Moura, pela ajuda na realização de todos os ensaios, pela motivação ao longo do desenvolvimento da dissertação e pelas várias "viagens" até a USP Leste.

Ao Prof. Walter Sant'Ana, pela amizade regada a muitas risadas e pelo incentivo profissional ao longo de todo o mestrado.

À minha querida amiga M. Enga. Rosângela Motta, pelo seu bom humor e carinho diários e pela ajuda no desenvolvimento desta dissertação.

Ao futuro engenheiro Moisés Abdou, pela ajuda na realização dos ensaios e das fotos e por me acompanhar, em vezes incontáveis, até a USP Leste.

A toda equipe, alunos e pesquisadores do LTP, em especial à amiga Diomária Santos, nossa querida secretária, e ao amigo Erasmo Alves, pela ajuda em toda a parte pesada dos ensaios.

Ao Prof. Carlos Pinto, pela amizade e por acreditar no meu potencial, quando eu já não mais acreditava.

À Fundação de Amparo à Pesquisa do Estado de São Paulo (FAPESP), pela bolsa de mestrado.

E a C. G. por fazer tudo isto valer muito a pena!! 


\section{RESUMO}

Os resíduos de construção e demolição (RCD) são gerados em quantidades expressivas nas cidades de grande e médio portes no Brasil e são comumente descartados de forma irregular. Para os milhares de quilômetros de vias urbanas não pavimentadas, o agregado reciclado de resíduo sólido da construção civil é uma alternativa aos materiais convencionais de pavimentação. Esta dissertação analisa o comportamento mecânico do agregado reciclado para emprego em camadas de base e sub-base. A pesquisa consiste em ensaios laboratoriais, acompanhados de um estudo de caso - o pavimento do novo campus da Universidade de São Paulo (USP Leste). Um trecho de 1.020 metros de extensão foi utilizado no estudo, de um total de aproximadamente dois quilômetros de vias pavimentadas no campus. O pavimento avaliado possui agregado reciclado em sua estrutura; quatro seções-tipo diferentes foram construídas, variando os materiais, as espessuras, a compactação e o subleito. Propriedades físicas e mecânicas do agregado reciclado foram determinadas em laboratório por meio dos seguintes testes: composição, porcentagem de materiais indesejáveis, massa específica, absorção de água, graduação, forma dos grãos, compactação, influência da compactação, índice de suporte Califórnia, módulo de resiliência e deformação permanente. Os ensaios de campo compreenderam: controle de materiais e de execução, resistência à penetração pelo Dynamic Cone Penetrometer e levantamento deflectométrico com o Falling Weight Deflectometer. Baseado na análise das bacias de deflexão das seções-tipo construídas, o trecho estudado é dividido em quatro comportamentos distintos à deformação. Os resultados mostraram que o comportamento mecânico do agregado reciclado apresenta uma forte dependência da eficiência da compactação. Quando submetido a uma compactação adequada, o material reciclado comporta-se tal qual uma brita graduada simples. 


\begin{abstract}
Construction and demolition waste (CDW) is generated in significant amounts in medium and large size cities in Brazil and are usually disposed of illegally. For the thousands of kilometers of unpaved urban roads, the recycled aggregate of CDW is an alternative to conventional paving materials. This dissertation analyses the mechanical behavior of the recycled aggregate for use in base and subbase layers. This research consisted of a series of laboratory tests, followed by a case study - the pavement of the new campus of the University of Sao Paulo (USP Leste). A test track of 1,020 meters of extension was used for the study, from a total of approximately two kilometers of paved roads in the campus. The pavement studied contains recycled aggregate in its structure; four different road sections were constructed, varying the materials, thickness, compaction and subgrade. Physical and mechanical properties of the recycled aggregate were characterized through the following laboratory tests: composition, percentage of impurities, bulk density, water absorption, gradation, grain form, compaction, compaction influence, California Bearing Ratio, resilient modulus and permanent deformation. The field tests covered: materials and construction control, bearing capacity using the Dynamic Cone Penetrometer and deflection measurement using a Falling Weight Deflectometer. Based on the analysis of the deflection basins of the built road sections, the test track is divided according to four different deformation behaviors. The results show that the mechanical behavior of the recycled aggregate presents a strong dependence on the compaction effort. When submitted to proper compaction, the recycled material behaves as a crushed-stone.
\end{abstract}




\section{SUMÁRIO}

\section{LISTA DE FIGURAS}

\section{LISTA DE TABELAS}

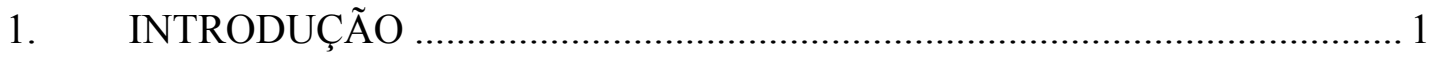

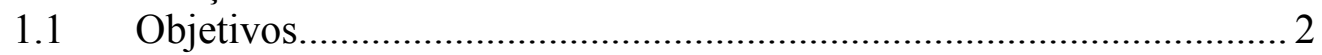

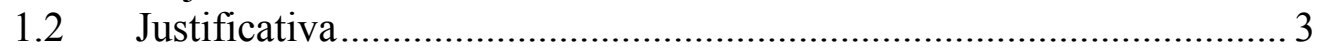

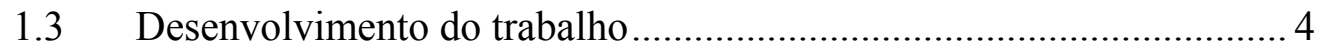

1.4 Organização do trabalho ................................................................... 4

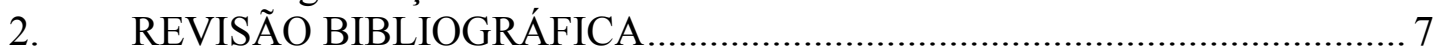

2.1 Resíduos de construção e demolição ................................................. 7

2.2 Reciclagem ........................................................................... 13

2.3 Agregado reciclado de resíduo sólido da construção civil em pavimentação

2.3.1 Pavimentação com agregado reciclado: experiências

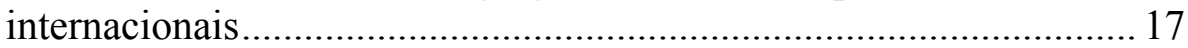

2.3.2 Pavimentação com agregado reciclado no Brasil ................... 22

2.3.3 Normalização internacional e nacional ................................. 28

\section{ESTUDO DE CASO: PAVIMENTO DO SISTEMA VIÁRIO DA USP}

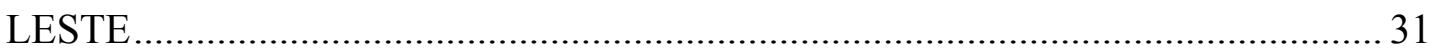

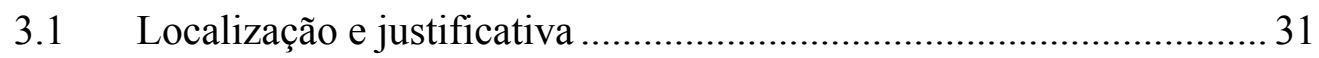

3.2 Dimensionamento do pavimento ................................................. 32

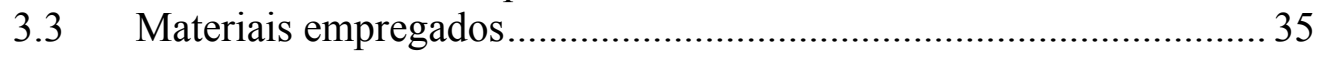

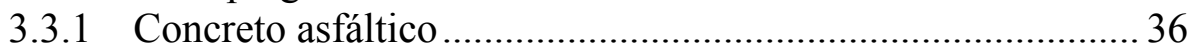

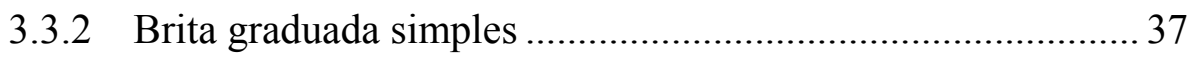

3.3.3 Solo laterítico para reforço de subleito .................................... 39

3.3.4 "Rachão de entulho"............................................................. 39

3.3.5 Agregado reciclado de resíduo sólido da construção civil ..... 40

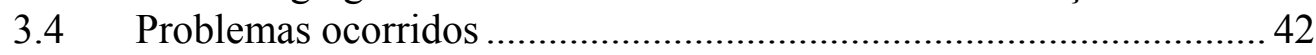

3.5 Discussão sobre o estudo laboratorial e monitoramento planejados .. 43

4. PROGRAMA EXPERIMENTAL: LABORATÓRIO E CAMPO ................ 45

4.1 Material analisado em laboratório ...................................................... 45

4.2 Ensaios de caracterização física em laboratório ................................ 47

4.2.1 Composição do agregado reciclado....................................... 47

4.2.2 Materiais indesejáveis ........................................................ 47

4.2.3 Determinação da massa específica dos grãos ......................... 48

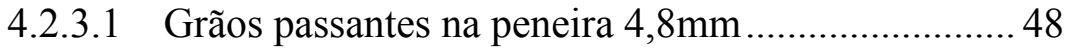

4.2.3.2 Grãos retidos na peneira 4,8mm …......................... 49

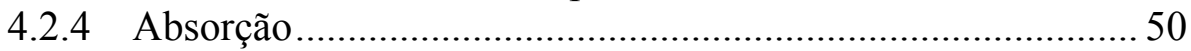

4.2.5 Análise granulométrica....................................................... 52

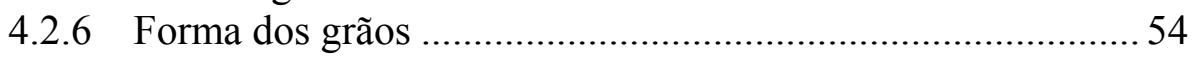

Ensaios de compactação ............................................................ 56

4.3.1 Determinação da umidade ótima e peso específico aparente seco máximo ................................................................................ 56

4.3.2 Compactação de corpos-de-prova de $150 \mathrm{~mm}$ x $300 \mathrm{~mm}$......... 58

4.3.3 Análise da influência da compactação .................................... 60 


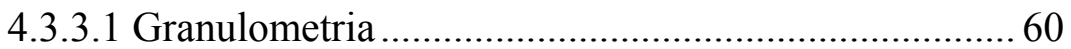

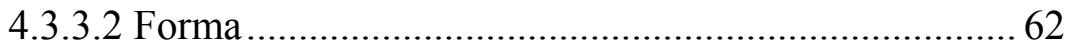

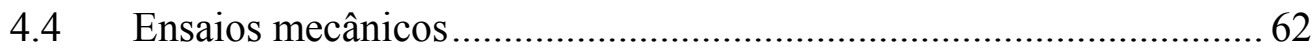

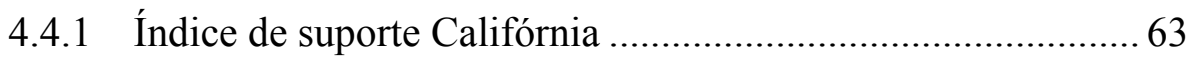

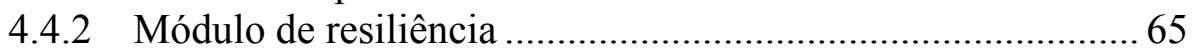

4.4.3 Deformação permanente.................................................... 70

4.4.3.1 Avaliação da deformação permanente....................... 70

4.4.3.2 Teoria do shakedown ..................................................... 75

4.5 Controle tecnológico em campo …................................................ 78

4.5.1 Controle tecnológico dos materiais ......................................... 79

4.5.2 Controle tecnológico de execução.......................................... 81

4.5.2.1 Controle da umidade................................................ 82

4.5.2.2 Controle do grau de compactação.............................. 82

4.5.3 Dynamic Cone Penetrometer ................................................. 84

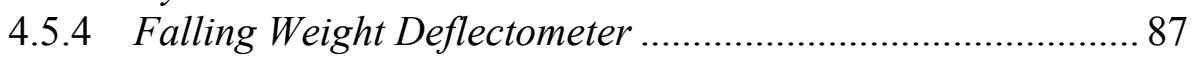

4.6 Estudo das bacias de deflexão ........................................................... 90

5. APRESENTAÇÃO E DISCUSSÃO DOS RESULTADOS .......................... 92

5.1 Caracterização física do agregado reciclado em laboratório ............... 92

5.1.1 Composição do agregado reciclado...................................... 92

5.1.2 Materiais indesejáveis ......................................................... 93

5.1.3 Determinação da massa específica dos grãos ........................ 94

5.1.3.1 Grãos passantes na peneira $4,8 \mathrm{~mm}$........................ 94

5.1.3.2 Grãos retidos na peneira $4,8 \mathrm{~mm}$............................ 95

5.1.4 Absorção...................................................................... 95

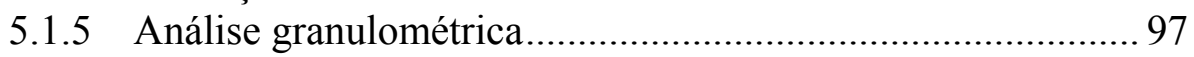

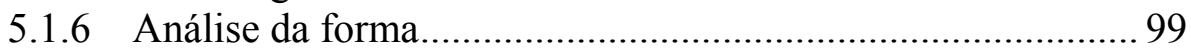

5.2 Ensaio de compactação em laboratório ......................................... 100

5.2.1 Determinação da umidade ótima e peso específico aparente

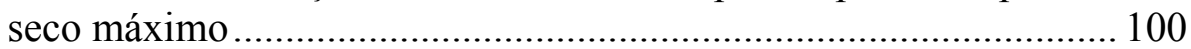

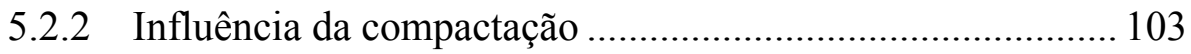

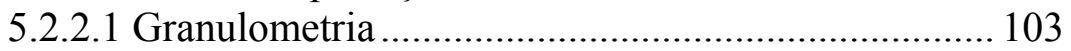

5.2.2.2 Forma ................................................................. 108

5.3 Comportamento mecânico do agregado reciclado em laboratório ... 108

5.3.1 Índice de suporte Califórnia ................................................ 108

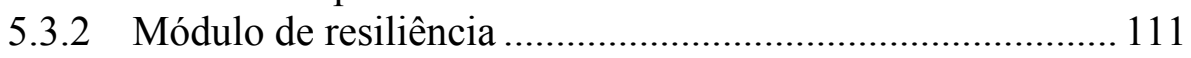

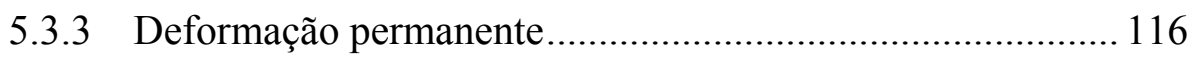

5.3.3.1 Deformação permanente ....................................... 116

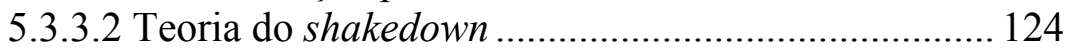

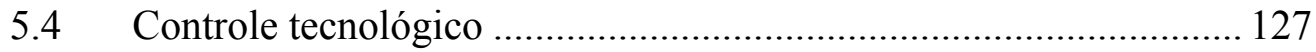

5.4.1 Controle tecnológico dos materiais .................................... 128

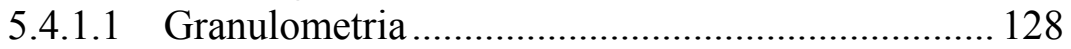

5.4.1.2 Forma dos grãos................................................ 132

5.4.1.3 Compactação..................................................... 133

5.4.1.4 Índice de suporte Califórnia.................................. 134

5.4.2 Controle tecnológico de execução....................................... 136

5.4.2.1 Umidade.............................................................. 136

5.4.2.2 Grau de compactação........................................... 138

5.4.3 Dynamic Cone Penetrometer ............................................... 140 
5.4.4 Falling Weight Deflectometer

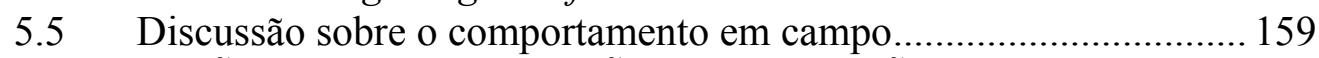

6. CONCLUSÕES, RECOMENDAÇÕES E SUGESTÕES ….......................... 166

REFERÊNCIAS BIBLIOGRÁFICAS ............................................................... 177

ANEXOS 


\section{LISTA DE FIGURAS}

Figura 2.1: Resíduos de construção e demolição (RCD) …......................................... 7

Figura 2.2: Disposição irregular de RCD (PINTO, 1999) ....................................... 12

Figura 2.3: Agregado reciclado de resíduo sólido da construção civil ....................... 14

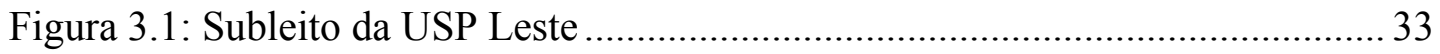

Figura 3.2: Quatro seções-tipo de pavimento executadas no sistema viário da USP

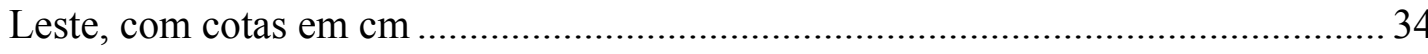

Figura 3.3: Limites da faixa II (camada intermediária) e da faixa III (camada de rolamento) da PMSP utilizadas no revestimento asfáltico do pavimento do sistema

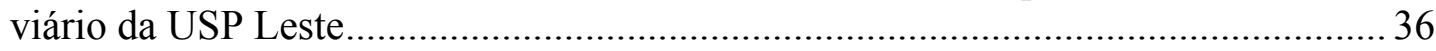

Figura 3.4: Vibroacabadora espalhando a mistura asfáltica.................................... 37

Figura 3.5: Compactação do revestimento asfáltico ................................................. 37

Figura 3.6: Base de agregado reciclado com imprimação impermeabilizante........... 37

Figura 3.7: Execução da pintura de ligação sobre a camada de binder ..................... 37

Figura 3.8: Camada de base de brita graduada simples sendo executada.................. 38

Figura 3.9: Granulometria da brita graduada simples empregada na seção-tipo 1 do

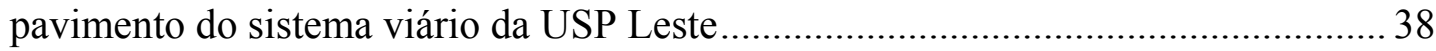

Figura 3.10: "Rachão de entulho" colocado sobre solo mole do subleito do sistema

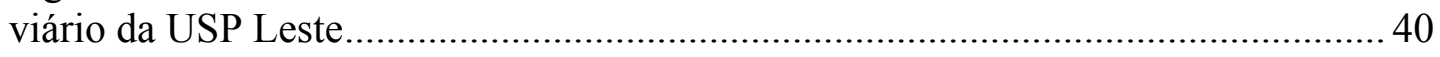

Figura 3.11: Camada de "rachão de entulho"após compactação ............................... 40

Figura 3.12: Pilha de agregado reciclado armazenada na obra ................................ 41

Figura 3.13: Motoniveladora espalhando a camada de agregado reciclado............... 42

Figura 3.14: Compactação de camada de agregado reciclado .................................. 42

Figura 4.1: Coleta do agregado reciclado com pá carregadeira ................................45

Figura 4.2: Descarregamento do agregado reciclado no laboratório ......................... 45

Figura 4.3: Homogeneização do material ................................................................. 46

Figura 4.4: Pilha de agregado reciclado no laboratório ............................................ 46

Figura 4.5: Acondicionamento do agregado reciclado em sacos plásticos................ 46

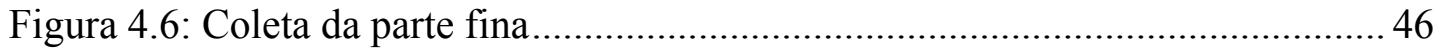

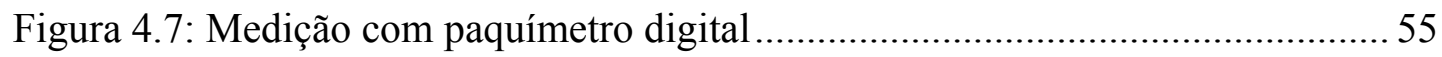

Figura 4.8: Exemplos de partículas pertencentes às frações analisadas..................... 55

Figura 4.9: Soquete grande e cilindro metálico grande ......................................... 57

Figura 4.10: Detalhe do cilindro e compactação......................................................57

Figura 4.11: Compactação no cilindro 150mm x 300mm ...................................... 59

Figura 4.12: Detalhe do cilindro tripartido …….....................................................5 
Figura 4.13: Corpos-de-prova em imersão para determinar expansão 65

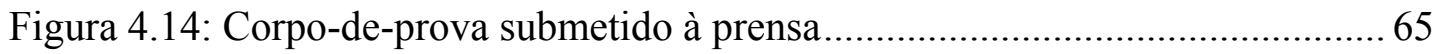

Figura 4.15: Equipamento triaxial de carga repetida do LTP-EPUSP .......................67 67

Figura 4.16: Célula triaxial grande utilizada no ensaio com carga repetida .............. 68

Figura 4.17: Corpo-de-prova de agregado reciclado com 150mm x 300mm ........... 68

Figura 4.18: Deformação permanente para um material granular apresentando os limites A, B e C (WERKMEISTER et al., 2001) ..................................................... 76

Figura 4.19: Equipamento frasco de areia................................................................ 83

Figura 4.20: Camada de base após ensaio com frasco de areia ............................... 83

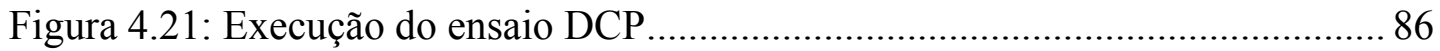

Figura 4.22: Detalhe da superfície após o ensaio DCP sobre camada de reforço de

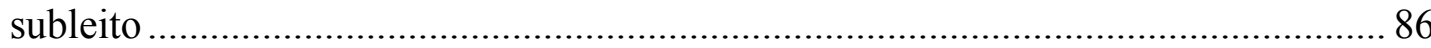

Figura 4.23: Deflexão gerada pelo carregamento no pavimento (PINTO e

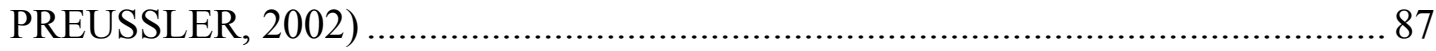

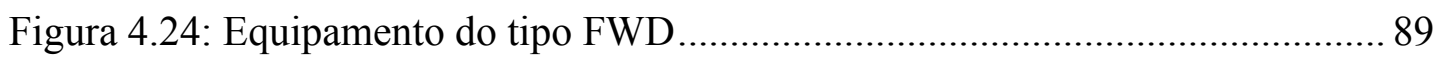

Figura 4.25: Detalhe da aplicação da carga e sensores .......................................... 89

Figura 5.1: Materiais constituintes do agregado reciclado estudado ........................ 92

Figura 5.2: Porcentagem em massa dos materiais presentes na fração graúda do agregado reciclado de Santo André analisado em laboratório .................................. 93

Figura 5.3: Granulometria inicial do agregado reciclado de Santo André................. 98

Figura 5.4: Composição granulométrica para ensaios com substituição de material

Figura 5.5: Curvas de compactação para energias intermediária e modificada....... 102 Figura 5.6: Curvas granulométricas do agregado reciclado de Santo André antes e depois da compactação, em relação à porcentagem passante

Figura 5.7: Curvas granulométricas do agregado reciclado de Santo André antes e depois da compactação, em relação à porcentagem retida.

Figura 5.8: Módulo de resiliência do agregado reciclado de Santo André para corposde-prova compactados nas energias intermediária e modificada segundo o modelo em função de $\theta$

Figura 5.9: Módulo de resiliência do agregado reciclado de Santo André para corposde-prova compactados nas energias intermediária e modificada segundo modelo em função de $\sigma_{3}$

Figura 5.10: Deformação permanente obtida para o agregado reciclado de Santo André compactado na energia intermediária e modificada.

Figura 5.11: Deformação permanente obtida para o agregado reciclado de Santo André compactado na energia modificada submetido a diferentes níveis de tensão 118 Figura 5.12: Deformação permanente obtida para o agregado reciclado de Santo André e para a brita com mesma granulometria compactados na energia modificada 
Figura 5.13: Análise do índice de deformação permanente para o agregado reciclado de Santo André compactado na energia intermediária e modificada

Figura 5.14: Análise do índice de deformação permanente para o agregado reciclado de Santo André compactado na energia modificada submetido a diferentes níveis de tensões

Figura 5.15: Deformação permanente obtida para o agregado reciclado de Santo André em nível de tensão baixo e alto

Figura 5.16: Granulometrias dos agregados reciclados empregados no sistema viário da USP Leste.

Figura 5.17: Granulometria dos agregados reciclados empregados no sistema viário da USP Leste depois da compactação da camada de sub-base.

Figura 5.18: Curva DCP e determinação das espessuras das camadas do local $0,690 \mathrm{~km}$

Figura 5.19: Resultados de ISC pela equação do USACE (1994) para as camadas do pavimento analisadas entre os locais $0,440 \mathrm{~km}$ e $0,710 \mathrm{~km}$.

Figura 5.20: Bacias de deflexão médias medidas em campo para o segmento homogêneo 1 - seção-tipo 1

Figura 5.21: Bacias de deflexão médias medidas em campo para o segmento homogêneo 2 - seção-tipo 2 .

Figura 5.22: Bacias de deflexão médias medidas em campo para o segmento homogêneo 3 - seção-tipo 3 .

Figura 5.23: Bacias de deflexão médias medidas em campo para o segmento homogêneo 4 - seção-tipo 4 .

Figura 5.24: Análise das bacias de deflexão médias medidas no eixo para os segmentos homogêneos 1 e 2 .

Figura 5.25: Análise das bacias de deflexão médias medidas no eixo para os segmentos homogêneos 2 e 3 .....

Figura 5.26: Análise das bacias de deflexão médias medidas no eixo para os segmentos homogêneos 3 e 4 .....

Figura 5.27: Análise das bacias de deflexão médias medidas no eixo para os segmentos homogêneos 1,2 e 4 .

Figura 5.28: Análise da média das bacias de deflexão medidas no eixo e da média das bacias de deflexão calculadas por retroanálise para o segmento homogêneo 1160

Figura 5.29: Análise da média das bacias de deflexão medidas no eixo e da média das bacias de deflexão calculadas por retroanálise para o segmento homogêneo 2160

Figura 5.30: Análise da média das bacias de deflexão medidas no eixo e da média das bacias de deflexão calculadas por retroanálise para o segmento homogêneo 3161

Figura 5.31: Análise da média das bacias de deflexão medidas no eixo e da média das bacias de deflexão calculadas por retroanálise para o segmento homogêneo 4161 


\section{LISTA DE TABELAS}

Tabela 2.1: Quantidade de RCD gerados e porcentagem reaproveitada ou reciclada em países da União Européia (EC, 2000) .

Tabela 2.2: Detalhamento das seções-tipo construídas na Pista Circular de Testes Acelerados da University of Central Florida (CHINI et al., 2001).....

Tabela 3.1: Características da brita graduada simples empregada na seção-tipo 1 do pavimento do sistema viário da USP Leste..

Tabela 3.2: Aspectos prescritos pela NBR 15115 (ABNT, 2004) com relação às características do agregado reciclado de resíduo sólido da construção civil para emprego em camadas de base e sub-base

Tabela 4.1: Aspectos e limites fixados pela norma e especificação brasileiras com relação à granulometria ....

Tabela 4.2: Classificação da forma dos grãos conforme NBR 6954 (ABNT, 1989). 55

Tabela 4.3: Valores mínimos de ISC e máximos de expansão recomendados para emprego de agregado reciclado em camadas de pavimentos.

Tabela 4.4: Tensões aplicadas durante o ensaio de módulo de resiliência do agregado reciclado de Santo André .....

Tabela 4.5: Energia e níveis de tensões empregados nos ensaios de deformação permanente do agregado reciclado de Santo André. 72

Tabela 4.6: Módulos de resiliência adotados na retroanálise da "seção-tipo 3"........ 72

Tabela 4.7: Controle tecnológico dos materiais conforme NBR 15115 (ABNT,2004)

Tabela 4.8: Controle tecnológico de execução de acordo com a NBR 15115

(ABNT,2004)

Tabela 5.1: Massa específica do agregado reciclado de Santo André relativa aos grãos passantes na peneira $4,8 \mathrm{~mm}$

Tabela 5.2: Massa específica dos grãos retidos na peneira 4,8 $\mathrm{mm}$ do agregado reciclado de Santo André, de acordo com natureza dos seus constituintes

Tabela 5.3: Absorção dos grãos retidos na peneira 4,8mm do agregado reciclado de Santo André, de acordo com natureza dos seus constituintes.................................. 96

Tabela 5.4: Teor de absorção para fração graúda de agregados reciclados .96

Tabela 5.5: Aberturas das peneiras e respectivas porcentagens passantes verificadas para o agregado reciclado de Santo André.

Tabela 5.6: Aspectos e limites fixados pela norma e especificação brasileiras com relação à granulometria .

Tabela 5.7: Forma dos grãos e respectivas porcentagens para o agregado reciclado de Santo André estudado em laboratório. 
Tabela 5.8: Forma dos grãos de acordo com a natureza para o agregado reciclado de Santo André estudado em laboratório

Tabela 5.9: Valores de peso específico seco máximo e umidade de compactação encontrados para agregados reciclados....

Tabela 5.10: Aberturas das peneiras e respectivas porcentagens passantes verificadas para o agregado reciclado de Santo André antes e depois da compactação.

Tabela 5.11: Aspectos e limites fixados pela norma e especificação brasileiras com relação à granulometria. 106

Tabela 5.12: Variações de índice de degradação de Ruiz para o agregado reciclado de Santo André de acordo com a energia de compactação 107

Tabela 5.13: Forma dos grãos e porcentagens após compactação em duas energias

Tabela 5.14: Valores de índice de suporte Califórnia obtidos para o agregado reciclado de Santo André compactado na energia intermediária e modificada 109

Tabela 5.15: Valores índice de suporte Califórnia para diferentes tipos de agregados reciclados

Tabela 5.16: Comparação de valores de módulo de resiliência para o agregado reciclado de Santo André compactado na energia intermediária e modificada utilizando diferentes níveis de tensões

Tabela 5.17: Modelos de módulo de resiliência obtidos para diferentes tipos de agregados reciclados

Tabela 5.18: Módulos de resiliência obtidos para mesmo nível de tensão utilizando os modelos apresentados na Tabela 5.17

Tabela 5.19: Deformações permanentes medidas por ensaios triaxiais de cargas repetidas para diferentes materiais de acordo com a literatura revisada.....

Tabela 5.20: Modelos obtidos com os ensaios de deformação permanente utilizando o modelo de Monismith et al.(1975).

Tabela 5.21: Modelos obtidos com os ensaios de deformação permanente utilizando o modelo de Barksdale (1972)

Tabela 5.22: Deformações permanentes obtidas nos ensaios e pelos modelos de previsão de Monismith et al.(1975) e Barksdale (1972) para 100.000 ciclos.

Tabela 5.23: Deformações permanentes verificadas na literatura para agregados reciclados utilizando os modelos de previsão de Monismith et al.(1975) e Barksdale (1972) para 100.000 ciclos

Tabela 5.24: Dimensão característica máxima dos grãos, porcentagem que passa na peneira $0,42 \mathrm{~mm}$, coeficiente de uniformidade e coeficiente de curvatura dos agregados reciclados empregados no sistema viário da USP Leste

Tabela 5.25: Resultados de porcentagem passante na peneira $0,42 \mathrm{~mm} \mathrm{e}_{\mathrm{u}}$ dos agregados reciclados empregados no sistema viário da USP Leste

Tabela 5.26: Resultados dos ensaios de compactação dos agregados reciclados empregados no sistema viário da USP Leste 
Tabela 5.27: Resultados de índice de suporte Califórnia e expansão dos agregados reciclados empregados no sistema viário da USP Leste.

Tabela 5.28: Resultados do controle da umidade de compactação dos agregados reciclados empregados nas camadas de base e sub-base do sistema viário da USP Leste

Tabela 5.29: Resultados do controle de compactação dos agregados reciclados empregados nas camadas de base e sub-base do sistema viário da USP Leste.

Tabela 5.30: Locais e superfície do pavimento do sistema viário da USP Leste onde foram realizados os ensaios com o DCP.

Tabela 5.31: Espessuras das camadas do pavimento do sistema viário da USP Leste obtidas por meio do DCP entre os locais $0,440 \mathrm{~km}$ e $0,710 \mathrm{~km}$

Tabela 5.32: Valores de DPI obtidos para as camadas do pavimento do sistema viário da USP Leste entre os locais $0,440 \mathrm{~km}$ e $0,900 \mathrm{~km}$

Tabela 5.33: Correlações entre DPI e índice de suporte Califórnia in situ para diferentes materiais verificadas na bibliografia consultada

Tabela 5.34: Cálculo do índice de suporte Califórnia in situ para diferentes materiais conforme correlações com o DPI verificadas na bibliografia consultada..... 145

Tabela 5.35: Valores de ISC médio, desvio padrão, coeficiente de variação e ISC mínimo estatístico obtidos para as camadas submetidas a ensaios DCP entre os locais 0,440km e $0,710 \mathrm{~km}$, utilizando o modelo USACE.

Tabela 5.36: Segmentos homogêneos analisados neste trabalho (cotas em cm) ..... 148

Tabela 5.37: Valores de $\mathrm{d}_{0}, \mathrm{~d}_{25}$ e $\mathrm{R}_{\mathrm{c}}$ médios da faixa esquerda, do eixo e da faixa direita para os segmentos homogêneos das quatro seções-tipo aqui analisadas ...... 153

Tabela 5.38: Valores de $\mathrm{d}_{0 \text { médio }}, \mathrm{d}_{\text {característica }}, \mathrm{d}_{\text {projeto }}$ e $\mathrm{d}_{\text {adm }}$ calculadas pelo método DNER PRO 011/79 (DNER, 1979)

Tabela 5.39: Módulos de resiliência das camadas dos quatro segmentos analisados determinados por retroanálise das bacias de deflexão medidas no eixo do pavimento

Tabela 5.40: Variações dos módulos de resiliência de cada camada dos quatro segmentos homogêneos analisados determinados por retroanálise das bacias de deflexão medidas no eixo do pavimento. 


\section{LISTA DE ABREVIATURAS E SIGLAS}

AASHO - American Association of State Highway Officials

AASHTO - American Association of State Highway and Transportation Officials

ABNT - Associação Brasileira de Normas Técnicas

ABPv - Associação Brasileira de Pavimentação

ANPET - Associação Nacional de Pesquisa e Ensino em Transporte

ASTM - American Society for Testing and Materials

BGS - Brita graduada simples

CAP - Cimento asfáltico de petróleo

CBR - California Bearing Ratio

$\mathrm{C}_{\mathrm{c}}$ - Coeficiente de curvatura

CONAMA - Conselho Nacional do Meio Ambiente

$\mathrm{C}_{\mathrm{u}}$ - Coeficiente de uniformidade

$\delta$ - Massa específica dos grãos

DER - Departamento de Estradas de Rodagem

DCP - Dynamic Cone Penetrometer (Penetrômetro Dinâmico de Cone)

DPI - DCP Penetration Index

DNER - Departamento Nacional de Estradas de Rodagem

DNIT - Departamento Nacional de Infra-estrutura de Transportes

DNPM - Departamento Nacional de Produção Mineral

EC - European Comission

$\varepsilon_{\mathrm{p}}$ - Deformação permanente

EPA - Environmental Protection Agency

ETS - Especificação Técnica de Serviço

FDOT - Florida Department of Transportation

FHWA - Federal Highway Administration

FWD - Falling Weight Deflectometer

HRB - Highway Research Board

ID - Índice de degradação

IPCC - Intergovernmental Panel on Climate Change

IPT - Instituto de Pesquisas Tecnológicas do Estado de São Paulo

ISC - Índice de suporte Califórnia

LVDT - Linear Variable Differencial Transformer

Mn/DOT - Minnesota Department of Transportation

$\mathrm{M}_{\mathrm{R}}$ - Módulo de resiliência 
ONU - Organização das Nações Unidas

PMSP - Prefeitura do Município de São Paulo

$\theta$ - Soma das tensões principais

RCD - Resíduo(s) de construção e demolição

$\sigma_{1}$ - Tensão principal maior

$\sigma_{3}$ - Tensão principal menor ou tensão de confinamento

$\sigma_{\mathrm{d}}-$ Tensão-desvio

USP - Universidade de São Paulo 


\section{INTRODUÇÃO}

A grande quantidade de resíduos provenientes dos diferentes processos do cotidiano industrializado e urbanizado é um assunto que preocupa hoje as empresas e a própria sociedade. Com o crescimento e o desenvolvimento das cidades, a indústria da construção civil depara-se com uma questão importante: a geração de resíduos sólidos pelas obras novas e demolições.

De acordo com Schneider (2003), estima-se que só no município de São Paulo sejam geradas diariamente cerca de 16.000 toneladas de resíduos de construção e demolição (RCD). Um agravante deste problema é a disposição irregular, que implica na poluição de vias, rios, córregos, terrenos baldios e áreas de mananciais (TRICHÊS e KRYCKYJ, 1999). Em função destes grandes volumes de RCD é patente a importância de estudos para que sejam encontradas soluções adequadas para o emprego deste material, evitando assim os danos ao meio em geral e os gastos excessivos com transporte e deposição em aterros.

De acordo com o relatório final Intergovernmental Panel on Climate Change (IPCC) de 2007 elaborado pela Organização das Nações Unidas (ONU), os resíduos sólidos e líquidos são responsáveis por $2,8 \%$ da emissão de $\mathrm{CO}_{2}$ e de outros gases que colaboram para o aquecimento global. O relatório recomenda que sejam adotadas políticas de gerenciamento dos resíduos para reduzir a sua geração e estimular a sua reciclagem, por meio do desenvolvimento e da difusão de novas tecnologias (IPCC, 2007).

Com a busca pelo desenvolvimento sustentável são apresentadas alternativas para o reaproveitamento dos resíduos da construção civil. Por meio da reciclagem do RCD é possível ter uma economia energética e reduzir os impactos negativos dos resíduos nas cidades. Uma nova matéria-prima é produzida e pode substituir a natural, nãorenovável (ÂNGULO et al., 2003). 
No Brasil, foi aprovada no ano de 2002 a resolução do Conselho Nacional do Meio Ambiente $n^{0} 307$ (CONAMA) que estabelece diretrizes, critérios e procedimentos para a gestão dos resíduos da construção civil. De acordo com esta resolução, os geradores são responsáveis pelos resíduos das atividades de construção, reforma, reparos e demolições de estruturas e estradas. Além disso, eles devem ter como prioridade a não geração de resíduos e, secundariamente, a redução, a reutilização, a reciclagem e a destinação final (CONAMA, 2002).

A resolução CONAMA no 307 (CONAMA, 2002) divide os resíduos da construção civil em quatro classes, indicando os que apresentam potencial para serem reutilizáveis ou recicláveis como agregados.

O RCD é um material nobre do ponto de vista de engenharia, pois normalmente se apresenta resistente e com baixa expansão. Estas características indicam o seu grande potencial de reciclagem como agregado para pavimentação. Estudos analisando as propriedades físicas, químicas e mecânicas do RCD para utilização em pavimentação vêm sendo desenvolvidos no Brasil desde a década de 80 (TRICHÊS e KRYCKYJ, 1999; MOTTA, 2005).

A partir da reciclagem do $\mathrm{RCD}$, um novo produto é obtido: o agregado reciclado de resíduo sólido da construção civil. Como forma de estimular e regulamentar o emprego do agregado reciclado em pavimentação, foi elaborada em 2004 pela Associação Brasileira de Normas Técnicas (ABNT) a norma NBR 15115, cujo título é “Agregados reciclados de resíduos sólidos da construção civil - Execução de camadas de pavimentação - Procedimentos" (ABNT, 2004).

\section{$1.1 \quad$ Objetivos}

Esta pesquisa tem por objetivo geral estudar o comportamento mecânico de agregado reciclado de resíduo sólido da construção civil em laboratório e em campo, para emprego em camadas de pavimentos de vias de baixo volume de tráfego.

Do ponto de vista inovador, este trabalho teve os seguintes objetivos: 
- Analisar a influência da energia de compactação nas propriedades físicas e mecânicas de agregado reciclado em laboratório;

- Avaliar a deformação permanente do agregado reciclado em laboratório, sob a luz da teoria do shakedown.

\subsection{Justificativa}

A preocupação com passivos ambientais e com um destino adequado para a grande quantidade de resíduos provenientes da construção civil, incentiva as pesquisas na área de reciclagem destes materiais. $\mathrm{O}$ emprego do agregado reciclado em pavimentação tem as seguintes vantagens e atrativos (TRICHÊS e KRYCKYJ, 1999; VON STEIN, 2000; CARNEIRO et al., 2001; CHINI et al., 2001; SOBHAN e MASHNAD, 2002; MOTTA, 2005; BLANKENAGEN e GUTHRIE, 2006):

- Diminuição dos custos de pavimentação, uma vez que estes materiais apresentam custo inferior aos convencionais (não considerando os gastos com transporte);

- Expansibilidade muito baixa ou nula, ou seja, com a entrada de água ou "saturação" não ocorre a expansão das camadas compactadas;

- Potencial de auto-cimentação, em função da presença de atividade pozolânica;

- Diminuição dos custos de operação de aterros sanitários, devido à menor quantidade de resíduo envolvido;

- Necessidade de áreas menores para a manutenção de aterros sanitários e botaforas, em função do prolongamento da vida útil dos existentes;

- Melhoria das condições de saneamento dos municípios;

- Economia com a limpeza urbana, colaborando com programas municipais de gerenciamento de resíduos sólidos;

- Economia de jazidas minerais naturais, devido à menor velocidade de exploração das mesmas, com conseqüente diminuição de agressão ao meio ambiente.

Espera-se que com os resultados obtidos e a divulgação desta experiência, seja estimulada a utilização do agregado reciclado, quando possível, em substituição ao 
material natural não-renovável, como britas graduadas ou materiais estabilizados granulometricamente.

\subsection{Desenvolvimento do trabalho}

Este trabalho consiste no estudo de agregados reciclados de resíduo sólido da construção civil em pavimentação. A pesquisa fundamenta-se em duas partes: a análise laboratorial de agregado reciclado e a análise em campo de agregado reciclado como camada de pavimento.

O pavimento estudado localiza-se no novo campus da Universidade de São Paulo, a USP Leste, na zona leste da capital paulista. Este pavimento possui aproximadamente dois quilômetros de extensão e é composto pela seguinte estrutura e materiais:

- Revestimento: concreto asfáltico com asfalto-borracha;

- Base e sub-base: agregado reciclado de resíduo sólido da construção civil;

- Reforço de subleito: solo importado com comportamento laterítico.

As camadas de base e sub-base com agregado reciclado foram o foco principal deste trabalho. Para a avaliação do seu comportamento in situ na estrutura, foi executado um controle tecnológico durante a construção do pavimento e após sua finalização. A análise laboratorial de agregado reciclado foi realizada com amostra coletada em campo, durante a implantação do pavimento na USP Leste.

\subsection{Organização do trabalho}

Esta dissertação de mestrado está organizada em seis capítulos.

Primeiramente, o capítulo 1 INTRODUÇÃO apresenta uma visão geral sobre a questão da geração dos resíduos da construção civil e a importância de sua reciclagem, além do objetivo da pesquisa, justificativa do estudo e organização do trabalho. 
Em seguida, no capítulo 2, REVISÃO BIBLIOGRÁFICA, são expostos o processo de geração dos resíduos de construção e demolição, o seu sistema de reciclagem, a obtenção do agregado reciclado, suas particularidades e seus possíveis empregos. A revisão bibliográfica também apresenta a resolução CONAMA nº 307 (CONAMA, 2002) e normas existentes que incentivam e regulamentam o uso do agregado reciclado como camadas de pavimentos e alguns conceitos básicos sobre pavimentação. São relatadas ainda neste mesmo capítulo pesquisas internacionais e nacionais já realizadas e experiências práticas de sucesso, indicando a potencialidade do uso deste material em pavimentação.

O capítulo 3, ESTUDO DE CASO: PAVIMENTO DO SISTEMA VIÁRIO DA USP LESTE, detalha o sistema viário construído no campus da USP Leste, experimentofoco deste trabalho. São apresentadas as características do local de implantação do campus, as seções-tipo construídas, os materiais empregados e problemas ocorridos durante a construção do pavimento.

$\mathrm{Na}$ seqüência, o capítulo 4 apresenta o PROGRAMA EXPERIMENTAL: LABORATÓRIO E CAMPO. Neste capítulo é descrito o material estudado em laboratório, o procedimento de sua coleta na obra e os ensaios laboratoriais conduzidos. Com relação ao campo, são apresentados o controle tecnológico tradicional empregado, previsto na norma NBR 15115 (ABNT, 2004), e o monitoramento complementar com uma avaliação estrutural.

O capítulo 5 compreende a APRESENTAÇÃO E DISCUSSÃO DOS RESULTADOS dos ensaios realizados em laboratório e em campo. É feita uma comparação com o estabelecido na norma NBR 15115 (ABNT, 2004), verificando a concordância do agregado reciclado com as especificações. São apresentados e discutidos os resultados dos ensaios mecânicos com o agregado reciclado. Este capítulo compreende ainda os resultados do controle tecnológico e a análise dos módulos de resiliência dos materiais em campo, obtidos por retroanálise estrutural com o programa computacional ELSYM5. 
Finalizando este trabalho, o capítulo 6, CONCLUSÕES, RECOMENDAÇÕES E SUGESTÕES, conclui sobre os resultados dos ensaios realizados em laboratório e em campo, além de apresentar recomendações para o emprego do agregado reciclado em camadas de pavimentos e sugestões para trabalhos futuros. 


\section{REVISÃO BIBLIOGRÁFICA}

\subsection{Resíduos de construção e demolição}

As principais atividades da indústria da construção civil, como construções, demolições, reformas e reparos apresentam freqüentemente sobras e desperdícios. Segundo Pinto (2003), os resíduos de construção e demolição (RCD), popularmente chamados de entulhos, representam cerca de dois terços da massa total de resíduos sólidos gerados nas cidades. A Figura 2.1 ilustra resíduos de construção e demolição.

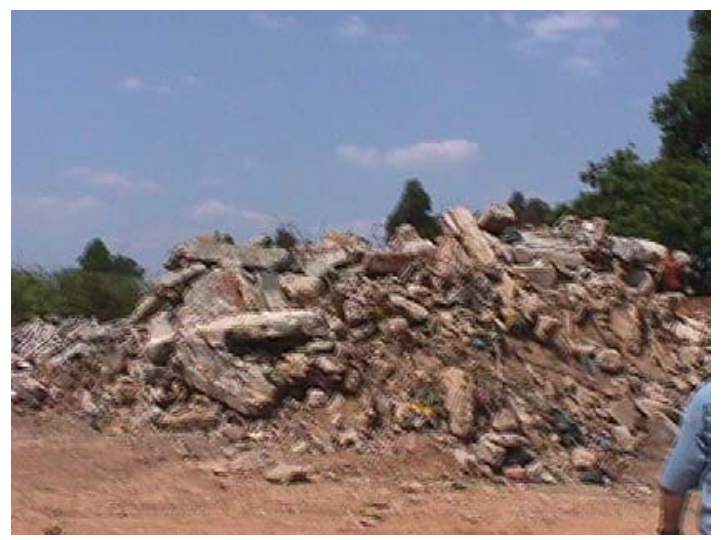

Figura 2.1: Resíduos de construção e demolição (RCD)

A resolução CONAMA no 307 (CONAMA, 2002) define os resíduos da construção civil como materiais provenientes de construções, reformas, reparos e demolições de obras de construção civil, e os resultantes da preparação e da escavação de terrenos, tais como: tijolos, blocos cerâmicos, concreto em geral, solos, rochas, metais, resinas, colas, tintas, madeiras e compensados, forros, argamassa, gesso, telhas, pavimento asfáltico, vidros, plásticos, tubulações, fiação elétrica, etc., comumente chamados de entulhos de obras, caliça ou metralha.

A seguinte classificação dos resíduos da construção civil é estabelecida pela resolução CONAMA n 307 (CONAMA, 2002):

- Classe A: são os resíduos reutilizáveis ou recicláveis como agregados, provenientes de construções, demolições, reformas e reparos de pavimentação, edificações e peças pré-moldadas em concreto; 
- Classe B: são os resíduos recicláveis para outras destinações, tais como: plásticos, papel/papelão, metais, vidros, madeiras e outros;

- Classe C: são os resíduos para os quais não foram desenvolvidas tecnologias ou aplicações economicamente viáveis que permitam a sua reciclagem/recuperação, tais como os produtos oriundos do gesso;

- Classe D: são os resíduos perigosos oriundos do processo de construção, tais como: tintas, solventes, óleos e outros, ou aqueles contaminados oriundos de demolição, reformas e reparos de clínicas radiológicas, instalações industriais e outros.

Com relação à classificação dos resíduos sólidos como potencialmente poluentes, existem no Brasil as seguintes normas da Associação Brasileira de Normas Técnicas $(\mathrm{ABNT})$ :

- NBR 10004 (2004) - Resíduos sólidos - Classificação: classifica os resíduos sólidos como seco ou molhado (análise da natureza física), como matéria orgânica ou inorgânica (análise da composição química) e como perigoso, não inerte e inerte (análise do risco potencial ao meio ambiente);

- NBR 10005 (2004) - Lixiviação de resíduos - Procedimento para obtenção de extrato lixiviado de resíduos sólidos: prescreve procedimentos para lixiviação de resíduos tendo em vista a sua classificação;

- NBR 10006 (2004) - Solubilização de resíduos - Procedimento para obtenção de extrato solubilizado de resíduos sólidos: prescreve sobre a solubilização de resíduos e fixa condições exigíveis para diferenciar os resíduos não inertes. É aplicada somente para resíduos sólidos;

- NBR 10007 (2004) - Amostragem de resíduos: fixa condições exigíveis para amostragem, preservação e estocagem de amostras de resíduos sólidos.

Estudos para avaliar o potencial de contaminação dos RCD, tanto nos aterros como para outras finalidades, devem ser realizados já que a composição dos resíduos varia muito de um lugar para outro. É afetada por uma série de fatores, como, por exemplo, os materiais e as técnicas de construção e demolição empregadas (EC, 2000). 
Outro fator importante é a contaminação que o resíduo pode sofrer. No Brasil, caçambas colocadas junto ao meio fio são contaminadas por outros tipos de resíduos, como restos de comida, móveis velhos, plantas e vegetais em geral, entre outros. Além disso, o tempo de estocagem do resíduo é importante, pois pode possibilitar transformações, como a hidratação das escórias e das cinzas de resíduo urbano, e que freqüentemente torna ainda mais aguda a contaminação ambiental (JOHN e ROCHA, 2003).

Dessa forma, as características intrínsecas dos resíduos são afetadas, fazendo-se necessário realizar um estudo aprofundado para verificar a viabilidade do seu reaproveitamento (JOHN e ROCHA, 2003). A variabilidade e a contaminação são grandes obstáculos no desenvolvimento das pesquisas e na difusão da reciclagem dos RCD (VON STEIN, 2000).

Apesar das particularidades dos resíduos de construção e demolição, a geração de grandes volumes destes materiais tem chamado a atenção de muitos países. Nas décadas de 70 e 80, o custo para depositar os resíduos em aterros aumentou muito, atingindo valores médios de U\$100,00 por tonelada na Europa e nos Estados Unidos. Assim, a busca por soluções alternativas, como reaproveitamento e reciclagem, atraíram o setor público (VON STEIN, 2000).

A União Européia pratica desde 1996 uma política de gerenciamento dos resíduos de construção e demolição, por estes constituírem uma alta parcela dos resíduos totais gerados. Estima-se que sejam produzidas na Europa cerca de 180 milhões de toneladas destes resíduos anualmente (EC, 2000). Não são todos os países membros que adotam métodos de gerenciamentos para seus RCD, mas os países que introduziram este sistema atingem hoje elevados níveis de reaproveitamento e reciclagem. A Tabela 2.1 apresenta alguns países pertencentes à União Européia, com as respectivas quantidades de RCD geradas anualmente e a porcentagem reaproveitada ou reciclada. 
Tabela 2.1: Quantidade de RCD gerados e porcentagem reaproveitada ou reciclada em países da União Européia (EC, 2000)

\begin{tabular}{|l|c|c|}
\hline \multicolumn{1}{|c|}{ País } & $\begin{array}{c}\text { RCD gerados } \\
{\left[\mathrm{x} 10^{6} \text { ton/ano }\right]}\end{array}$ & $\begin{array}{c}\text { RCD reaproveitado } \\
\text { ou reciclado } \\
{[\%]}\end{array}$ \\
\hline Alemanha & 59 & 17 \\
\hline Reino Unido & 30 & 45 \\
\hline França & 24 & 15 \\
\hline Itália & 20 & 9 \\
\hline Espanha & 13 & $<5$ \\
\hline Holanda & 11 & 90 \\
\hline Bélgica & 7 & 87 \\
\hline Áustria & 5 & 41 \\
\hline Dinamarca & 3 & 81 \\
\hline Portugal & 3 & $<5$ \\
\hline Suécia & 2 & 21 \\
\hline Finlândia & 1 & 45 \\
\hline
\end{tabular}

Observa-se na Tabela 2.1 que as porcentagens de resíduos reaproveitados ou reciclados, apesar de serem consideráveis, diferem de um lugar para outro, porque os países adotam medidas de gerenciamento diferentes. Levantamentos indicam que $25 \%$ dos RCD produzidos na Europa são reciclados (EC, 2000).

Os elevados níveis de geração de RCD na Alemanha, no Reino Unido e na França ocorrem em função destes três países estarem entre os mais populosos da Europa.

A Holanda, a Bélgica e a Dinamarca introduziram medidas consistentes para melhorar o sistema de tratamento de seus resíduos e hoje se destacam na questão de reaproveitamento e reciclagem dos RCD (EC, 2000). Nestes países cerca de $80 \%$ a $90 \%$ dos resíduos da construção civil tem uma destinação melhor que a disposição em aterros.

Os países do sul da Europa, como Itália, Espanha e Portugal, possuem uma pequena parcela de reaproveitamento de seus RCD. As reservas naturais destes países fornecem qualidade e quantidade de agregados para a construção civil, por custos 
moderados. Assim, não existe nestes lugares um mercado desenvolvido para consumir estes materiais reciclados (EC,2000).

Nos Estados Unidos, várias estimativas sobre a geração de resíduos da construção civil vêm sendo feitas desde a década de 80 . Levantamentos indicaram que no ano de 1996 foram geradas no país cerca de 135,5 milhões de toneladas destes resíduos. Entre $35 \%$ e $45 \%$ deste montante foram destinados a aterros legais e entre $20 \%$ e $30 \%$ foram reaproveitados ou reciclados. Os materiais freqüentemente recuperados são os derivados de concreto, misturas asfálticas, metais e madeira (EPA, 1998).

Os estados americanos possuem autonomia para determinar as regulamentações e políticas de gerenciamento de seus resíduos; a destinação dos resíduos de construção e demolição em aterros tem sido cada vez menos tolerada pelos norte-americanos (EPA, 1998).

Na Austrália, em função do alto custo de manutenção e esgotamento rápido dos aterros, vêm sendo feitos esforços consideráveis para buscar um reaproveitamento dos RCD. Acredita-se que sejam geradas anualmente nas cidades de Sydney e Melbourne 400 mil toneladas e 300 mil toneladas de resíduos de construção e demolição, respectivamente (NATAATMADJA e TAN, 2001).

Nos últimos anos, vêm sendo realizados levantamentos para definir a quantidade de resíduos gerados pela construção civil no Brasil. Estima-se que sejam geradas anualmente 68,5 milhões de toneladas destes resíduos no país (ÂNGULO et al., 2003).

O reaproveitamento e a reciclagem são soluções ideais para estes grandes volumes de resíduos da construção civil. Contudo, o destino final para os RCD nem sempre é o mais adequado. Muitas vezes os RCD são dispostos de forma ilegal, tanto no Brasil como no exterior (PINTO, 1999; EPA, 1998; EC, 2000). 
Na cidade de São Paulo, estima-se que somente um terço do montante de RCD produzido chegue aos aterros públicos, ou seja, a grande maioria é descartada irregularmente (SCHNEIDER, 2003). A Figura 2.2 ilustra um exemplo de poluição de um córrego por resíduos sólidos entre as cidades de Santo André/SP e São Bernardo do Campo/SP (PINTO, 1999).

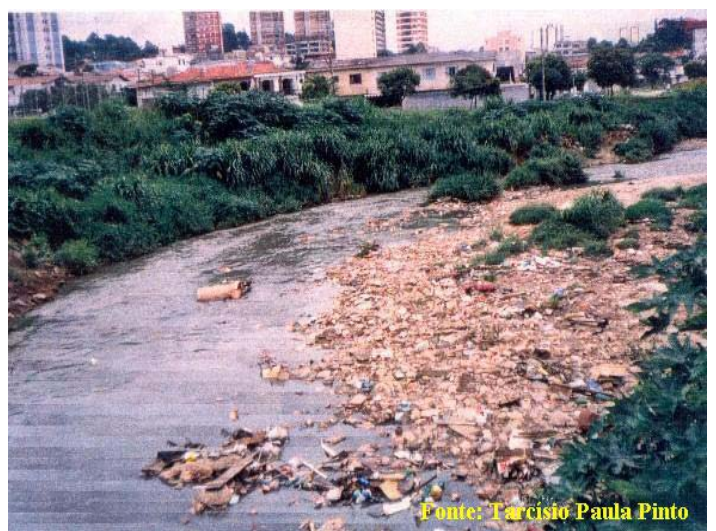

Figura 2.2: Disposição irregular de RCD (PINTO, 1999)

Além da poluição, a disposição ilegal dos resíduos provoca o assoreamento de rios e córregos e o entupimento de galerias e bueiros, contribuindo para as enchentes. A degradação das áreas urbanas é um fato lamentável, que influi diretamente sobre a saúde e a qualidade de vida da população (TRICHÊS e KRYCKYJ, 1999; PINTO, 1999; SCHNEIDER, 2003).

Quando coletados de forma legal, os resíduos da construção civil são encaminhados aos aterros, que apresentam altos custos de operação, tanto econômicos como ambientais. Além disso, os RCD são um dos principais responsáveis pelo esgotamento de áreas de aterros em cidades de médio e grande porte (ÂNGULO et al., 2003).

Em 1984, a Prefeitura do Município de São Paulo (PMSP) pavimentou sua primeira via com resíduo de construção e demolição, a Rua Gervásio da Costa. A construção teve acompanhamento do IPT (Instituto de Pesquisas Tecnológicas do Estado de São Paulo). A PMSP buscava novas alternativas para os resíduos da construção civil. A preocupação principal era possibilitar a sobrevida de aterros existentes, já que estes 
se encontravam praticamente esgotados (BODI et al.,1995). Foram desenvolvidos, então, estudos para verificar a viabilidade da reciclagem dos resíduos da construção civil.

\subsection{Reciclagem}

Na bibliografia há relatos de uso dos resíduos de demolições pela humanidade desde tempos muito antigos. A escassez de matérias-primas e as dificuldades de deposição dos resíduos implicaram no reaproveitamento destes materiais (VON STEIN, 2000).

A aplicação em larga escala dos resíduos da construção civil aconteceu na Europa e no Japão somente após a Segunda Guerra Mundial (NATAATMADJA e TAN, 2001). Durante o período de reconstrução das cidades era necessário remover todo o entulho que restou e satisfazer uma enorme demanda de materiais de construção. Dessa forma, o reaproveitamento dos resíduos possibilitou não só a limpeza das cidades, como também contribuiu para a economia na compra de materiais (SCHULZ e HENDRICKS, 1992). Neste período, a reconstrução do sistema viário foi considerada prioridade na Europa, fazendo com que países como a Alemanha e a França fossem pioneiros no desenvolvimento de técnicas de reciclagem dos RCD como materiais para pavimentação e construção civil (VON STEIN, 2000).

Para utilização como material de construção, o RCD deve ser do tipo classe A da resolução CONAMA no 307 (CONAMA, 2002) e deve sofrer um processo de reciclagem originando um novo produto: o agregado reciclado de resíduo sólido da construção civil. A Figura 2.3 ilustra o material reciclado. 


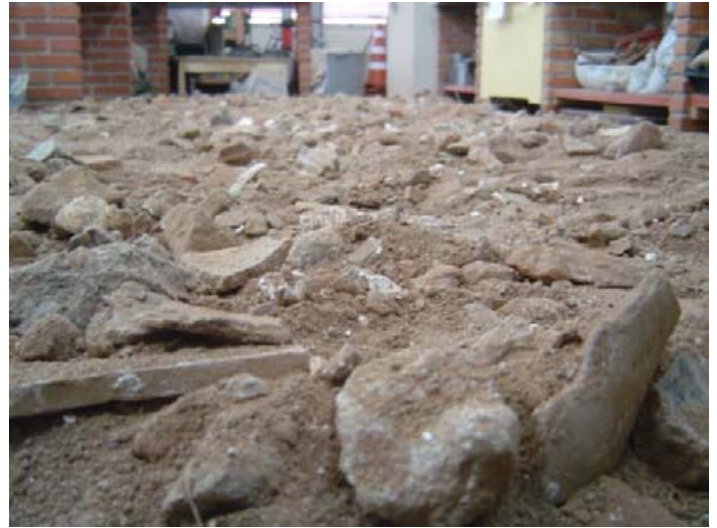

(a) Em laboratório

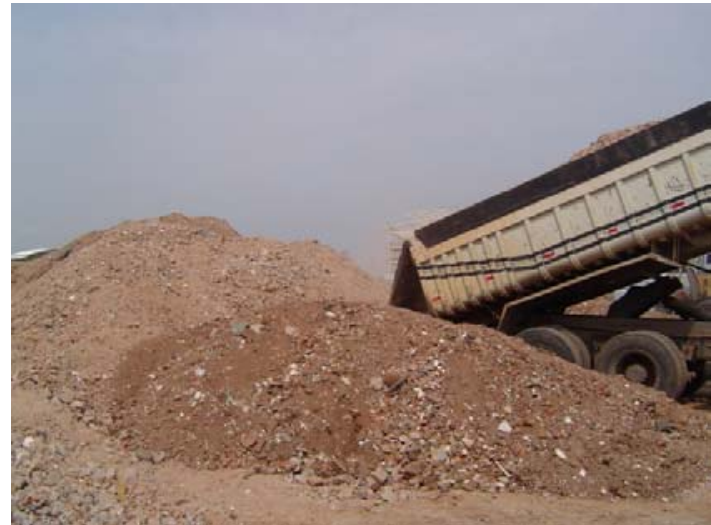

(b) Em obra de pavimentação

Figura 2.3: Agregado reciclado de resíduo sólido da construção civil

A transformação do RCD em agregado reciclado é realizada, normalmente, através das usinas recicladoras. Estas usinas apresentam uma planta bastante semelhante a uma usina de britagem convencional (BODI et al., 1995), utilizando os mesmos equipamentos empregados na produção de agregados naturais, no entanto, algumas etapas para limpeza e seleção são necessárias.

O processo de reciclagem consiste basicamente na britagem do RCD do tipo classe A, diminuindo o tamanho dos grãos e produzindo assim o agregado reciclado. Entretanto, o resíduo antes da britagem já deve ser pré-selecionado e passar por uma fase de catação, onde os materiais indesejáveis, como vidro, metais, borracha, gesso e madeira devem ser retirados. Além disso, comumente são instaladas nas correias transportadoras sistemas para realizar a separação magnética de elementos metálicos, como armaduras e pregos (ÂNGULO, 2005).

Muitas vezes as usinas recicladoras fazem uma pré-seleção do RCD, tendo assim três produtos diferentes (ÂNGULO et al., 2003; TRICHÊS e KRYCKYJ, 1999; FERNANDES, 2004):

- Agregado reciclado de concreto: chamado também de cinza ou branco, é principalmente composto por materiais cimentícios, como concretos e argamassas;

- Agregado reciclado vermelho: com predominância de materiais cerâmicos, como tijolos, telhas e pisos cerâmicos; 
- Agregado reciclado misto: quando possui menos de 90\% em massa de fragmentos à base de cimento Portland e rochas é denominado misto.

Os casos de reciclagem de maior sucesso são aqueles em que as usinas recicladoras foram implantadas em grandes cidades, onde existe um volume de resíduos da construção civil suficiente para manter uma produção constante de agregado reciclado (O’MAHONY e MILLIGAN, 1991).

No Brasil, a Prefeitura do Município de São Paulo (PMSP) implantou, no ano de 1991, a primeira usina recicladora do Brasil em Itatinga, na zona sul da cidade, com a finalidade de produzir agregados reciclados para sub-base de pavimentos (CARNEIRO et al., 2001). Este equipamento de reciclagem permaneceu desativado durante alguns anos e mais tarde voltou a operar de forma intermitente no bairro de Itaquera, na zona leste do município (SCHNEIDER, 2003).

\subsection{Agregado reciclado de resíduo sólido da construção civil em pavimentação}

Nas duas últimas décadas tem sido provada a viabilidade do uso dos RCD, após a sua reciclagem, em camadas de base e sub-base de pavimentos (POON e CHAN, 2006). Uma questão que estimula o desenvolvimento de técnicas para a reciclagem de RCD como material de pavimentação são os altos custos e a grande demanda de materiais virgens.

Nos Estados Unidos, o agregado reciclado de resíduo sólido da construção civil apresenta custo inferior em torno de $30 \%$, comparado com a brita graduada simples. Esta economia significativa tem incentivado muitos órgãos e construtoras a substituir, quando possível, o material natural pelo reciclado (BLANKENAGEL e GUTHRIE, 2006).

Segundo dados do DNPM (2005), a exploração de jazidas minerais para obtenção de agregados naturais tem uma produção altíssima e é responsável por um grande impacto ambiental. No Brasil em 2004, foram produzidos 172,4 milhões de toneladas 
de areia e rocha britada, sendo que a pavimentação respondeu por cerca de $20 \%$ deste total (DNPM, 2005).

O uso do agregado reciclado em pavimentação é uma alternativa muito interessante para substituir materiais naturais, não-renováveis, principalmente para os milhares de quilômetros de vias brasileiras ainda não pavimentadas. Segundo dados do Departamento Nacional de Estradas de Rodagem (DNIT) do ano 2005, cerca de 88\% da malha rodoviária nacional não é pavimentada, perfazendo $1.414 .000 \mathrm{~km}$. Deste montante $1.282 .000 \mathrm{~km}$ pertencem à rede municipal (COPPEAD, 2007).

Em relação às vias urbanas, de acordo com dados da Prefeitura do Município de São Paulo, a cidade possui aproximadamente $3.000 \mathrm{~km}$ de ruas e avenidas ainda não pavimentadas (PMSP, 1998). Incentivando a reciclagem do resíduo da construção civil, a PMSP estabeleceu no final de 2006 um decreto que obriga a utilização de agregados reciclados em obras e serviços de pavimentação das vias públicas do município. As contratações de obras e serviços de pavimentação de vias devem contemplar em seus projetos, em caráter preferencial, o emprego dos agregados reciclados. A partir de julho de 2007, os projetos deverão, obrigatoriamente, prever o uso de materiais reciclados (PMSP, 2006).

No entanto, em função da variabilidade na composição, os agregados reciclados de resíduo sólido da construção civil possuem particularidades de comportamento em relação aos materiais convencionais naturais empregados na pavimentação (MOTTA e FERNANDES, 2003). As características físicas dos agregados reciclados são muito diferentes dos agregados naturais. Por exemplo, a sua porosidade é alta, o que resulta em altas porcentagens de absorção de água (ZORDAN, 2003).

Dessa forma, ao utilizar-se o material produzido pelas usinas recicladoras em pavimentação, vários aspectos complementares de projeto e construção devem ser analisados. Como o material não é fornecido com uma característica constante, durante a execução do pavimento podem ser necessárias modificações no projeto. Por isso é tão importante o emprego de um controle tecnológico sério quando se 
emprega um material reciclado (BENNERT et al., 2000). Muitas pesquisas já indicaram que muitos métodos de controle de qualidade padrão não se aplicam aos agregados reciclados de resíduo sólido da construção civil (BLANKENAGEL e GUTHRIE, 2006).

A durabilidade do agregado reciclado ao longo da vida útil do pavimento é um assunto que ainda gera muitos questionamentos (NATAATMADJA e TAN, 2001). Por isso muitos órgãos que regulamentam o uso deste material em pavimentação não permitem ou estabelecem restrições sobre o uso em camadas de base. Para projetar e empregar o agregado reciclado é muito importante conhecer as especificações e normas existentes, procurando respeitar sempre as recomendações e limites estabelecidos (BENNERT et al., 2000; BLANKENAGEL e GUTHRIE, 2006).

\subsubsection{Pavimentação com agregado reciclado: experiências internacionais}

No início da década de 90, foram realizadas pesquisas no Reino Unido verificando a viabilidade do emprego de materiais reciclados de resíduos da construção civil em pavimentação. Segundo O’Mahony e Milligan (1991), apesar do Reino Unido ser relativamente rico em reservas naturais, o consumo de materiais de construção estava crescendo muito. Acreditava-se que no futuro a produção de agregados naturais não conseguiria suprir a procura por estes materiais.

A pesquisa inglesa verificou em laboratório as propriedades de resíduos britados de concreto e de alvenaria para emprego em camadas de sub-base. Uma amostra de brita calcária, que seria o material convencionalmente empregado no Reino Unido, foi também analisada para servir de referência comparativa. Por meio de ensaios de índice de suporte Califórnia verificou-se que os resíduos britados de concreto apresentaram comportamento semelhante ao da brita calcária. Já os resíduos britados de alvenaria apresentaram uma capacidade de suporte menor, em função da grande variabilidade da natureza de seus materiais constituintes. Contudo, todas as amostras analisadas apresentaram um índice de suporte Califórnia maior que 30\%, limite estipulado no Reino Unido para emprego em camada de sub-base (O’MAHONY e MILLIGAN, 1991). 
De acordo com o Federal Highway Administration, desde 1997, pelo menos 20 estados americanos empregam agregados reciclados de concreto na construção de pavimentos: Arizona, California, Colorado, Florida, Indiana, Iowa, Louisiana, Maryland, Massachussetts, Minnesota, Missouri, Nebraska, New Jersey, New York, North Dakota, Ohio, Pennsylvania, Rhode Island, South Carolina e Texas. Segundo FHWA (1997), o agregado reciclado de concreto tem se mostrado um excelente material granular para emprego em bases e sub-bases, apresentando boa capacidade de suporte, durabilidade e drenabilidade.

Desde o final da década de 90, em New Jersey nos Estados Unidos, foi verificada a viabilidade de utilização de agregado reciclado de concreto em base e sub-bases de pavimentos (BENNERT et al., 2000). Foi conduzido um extenso programa laboratorial, utilizando-se várias porcentagens de agregado reciclado misturado com brita graduada simples. Conduziram-se ensaios triaxiais de carga repetida, determinando o módulo de resiliência e a deformação permanente do agregado reciclado de concreto. Os resultados indicaram que o agregado reciclado de concreto e as misturas de agregado reciclado de concreto com a brita graduada simples apresentaram módulos de resiliência superiores ao da brita graduada simples. Contudo, o agregado reciclado de concreto apresentou deformação permanente maior que a brita graduada simples sob as mesmas condições de ensaio (BENNERT et al., 2000).

Entre 1996 e 1997, o Departamento de Transportes da Florida (Florida Department of Transportation - FDOT), nos Estados Unidos, desenvolveu metodologias e especificações para o uso de agregados reciclados de concreto em pavimentos flexíveis e rígidos (KUO et al., 2001). A intenção era maximizar o uso destes agregados reciclados, provenientes dos antigos pavimentos de concreto. As pesquisas compreenderam o uso tanto em bases e sub-bases, como na composição de concretos para pavimentos rígidos. O FDOT propõe reciclar o concreto retirado do pavimento a ser restaurado e aplicá-lo na reconstrução do mesmo, ou seja, no mesmo local. 
Assim, o processo de reciclagem é otimizado e os gastos com transporte e deposição de materiais são reduzidos (CHINI et al., 2001).

No ano 2000, foram construídas na Pista Circular de testes Acelerados da University of Central Florida nove seções-tipo diferentes, utilizando o agregado reciclado de concreto. Quatro seções-tipo eram de pavimento flexível e cinco seções-tipo eram de pavimento rígido. O detalhamento das seções-tipo construídas é apresentado na Tabela 2.2.

Tabela 2.2: Detalhamento das seções-tipo construídas na Pista Circular de Testes Acelerados da University of Central Florida (CHINI et al., 2001)

\begin{tabular}{|c|c|c|c|c|}
\hline \multirow{2}{*}{$\begin{array}{l}\text { Seção- } \\
\text { tipo }\end{array}$} & \multicolumn{2}{|c|}{ Revestimento } & \multicolumn{2}{|c|}{ Base } \\
\hline & Material & $\begin{array}{c}\text { Espessura } \\
{[\mathrm{mm}]}\end{array}$ & Material & $\begin{array}{c}\text { Espessura } \\
{[\mathrm{mm}]}\end{array}$ \\
\hline 1 & concreto asfáltico & 103 & $\begin{array}{l}100 \% \text { agregado } \\
\text { reciclado de } \\
\text { concreto }\end{array}$ & 250 \\
\hline 2 & concreto asfáltico & 103 & $\begin{array}{c}100 \% \text { brita } \\
\text { calcária }\end{array}$ & 200 \\
\hline 3 & concreto asfáltico & 103 & $\begin{array}{l}100 \% \text { agregado } \\
\text { reciclado de } \\
\text { concreto }\end{array}$ & 200 \\
\hline 4 & concreto asfáltico & 103 & $\begin{array}{l}100 \% \text { agregado } \\
\text { reciclado de } \\
\text { concreto }\end{array}$ & 300 \\
\hline 5 & $\begin{array}{l}\text { concreto de cimento } \\
\text { Porltand ( } 25 \% \text { agregado } \\
\text { reciclado de concreto e } \\
75 \% \text { agregado virgem) }\end{array}$ & 250 & $\begin{array}{c}\text { solo } \\
\text { AASHTO A3 }\end{array}$ & $\begin{array}{c}\text { não } \\
\text { especifica }\end{array}$ \\
\hline 6 & $\begin{array}{c}\text { concreto de cimento } \\
\text { Porltand (100\% } \\
\text { agregado virgem })\end{array}$ & 250 & $\begin{array}{c}\text { solo } \\
\text { AASHTO A3 }\end{array}$ & $\begin{array}{c}\text { não } \\
\text { especifica }\end{array}$ \\
\hline 7 & $\begin{array}{l}\text { concreto de cimento } \\
\text { Porltand ( } 100 \% \\
\text { agregado reciclado de } \\
\text { concreto) }\end{array}$ & 250 & $\begin{array}{c}\text { solo } \\
\text { AASHTO A3 }\end{array}$ & $\begin{array}{c}\text { não } \\
\text { especifica }\end{array}$ \\
\hline 8 & $\begin{array}{l}\text { concreto de cimento } \\
\text { Porltand ( } 75 \% \text { agregado } \\
\text { reciclado de concreto e } \\
25 \% \text { agregado virgem) }\end{array}$ & 250 & $\begin{array}{c}\text { solo } \\
\text { AASHTO A3 }\end{array}$ & $\begin{array}{c}\text { não } \\
\text { especifica }\end{array}$ \\
\hline 9 & $\begin{array}{c}\text { concreto de cimento } \\
\text { Porltand }(100 \% \\
\text { agregado virgem })\end{array}$ & 250 & $\begin{array}{l}100 \% \text { agregado } \\
\text { reciclado de } \\
\text { concreto }\end{array}$ & 250 \\
\hline
\end{tabular}


Para efeito comparativo, foram construídas as seções-tipo 2 e 6 , que possuem apenas materiais virgens em sua estrutura. Estas seções foram consideradas como seções de controle. Cada seção-tipo tinha aproximadamente quatro metros de extensão (CHINI et al., 2001).

A pista circular foi submetida ao carregamento de $49 \mathrm{kN}$ em cada eixo, com 363.000 repetições, e monitorada. Os resultados indicaram que ao fim do experimento não houve ruptura da estrutura de pavimento flexível. Não foram observadas trincas ou fissuras por fadiga nas seções-tipo com o agregado reciclado de concreto como camada de base, apresentando ainda, um desempenho superior ao da seção-tipo com apenas materiais virgens (CHINI et al., 2001; KUO et al., 2001; KUO et al., 2002).

Com relação ao trecho com pavimento rígido, o concreto de cimento Portland com $100 \%$ de agregado reciclado de concreto apresentou uma resistência à compressão simples aos 28 dias 20\% menor que o concreto da seção de controle, composto apenas por materiais virgens $(35,0 \mathrm{MPa}$ e $42,9 \mathrm{MPa}$, respectivamente). Após o carregamento, as seções-tipo 5 a 9 não apresentaram quaisquer defeitos ou irregularidades na superfície (CHINI et al., 2001).

Recentemente, o uso de agregados reciclados de concreto vem sendo também estudado no estado de Utah. O interesse principal na pesquisa por estes materiais deve-se ao seu potencial auto-cimentante. Foram conduzidos ensaios de compressão simples com diferentes tempos de cura. Os resultados obtidos indicaram um ganho considerável de resistência com o tempo: 0 a 3 dias houve um aumento de $130 \%$, e de 0 a 7 dias um aumento de 180\% (BLANKENAGEL e GUTHRIE, 2006). Conforme exposto pelos autores, acredita-se que este aumento de resistência ocorreu em função de reações pozolânicas e/ou da hidratação de partículas de cimento presentes nos agregados reciclados.

Na Austrália, desde a década de 90 o agregado reciclado de concreto é empregado em projetos de construção de rodovias, nas camadas de sub-base. Nataatmadja e Tan 
(2001) desenvolveram estudos para verificar a comportamento resiliente de agregados reciclados de concreto. Foram analisadas quatro amostras de agregados reciclados, provenientes de concretos com diferentes resistências à compressão: 15,0; 18,$5 ; 49,0$ e 75,0MPa. Os resultados obtidos indicaram que a resistência à compressão do concreto de origem influencia no módulo de resiliência e na deformação permanente do agregado reciclado de concreto. Contudo, o fator mais importante é a granulometria, pois materiais bem graduados apresentam módulos de resiliência mais elevados (NATAATMADJA e TAN, 2001).

Na Holanda, desde a década de 70, o reuso de resíduos de demolição de alvenaria e concreto como material para bases e sub-bases granulares de pavimentos é uma prática comum. Em 2002, Molenaar e van Niekerk estudaram em laboratório os efeitos da graduação, composição e grau de compactação do agregado reciclado nas suas propriedades mecânicas. Concluíram que a composição e a granulometria influem no desempenho do agregado reciclado para utilização em camadas de bases e sub-bases de pavimentos, mas o grau de compactação é claramente o fator mais importante. Este resultado se mostrou muito interessante, pois ainda que a graduação e a composição muitas vezes sejam parâmetros de difícil controle, a compactação eficiente é possível de ser realizada e fiscalizada a um custo baixo (MOLENAAR e VAN NIEKERK, 2002).

Em Hong Kong, um estudo recente investigou a possibilidade do uso de agregados reciclados de concreto e agregados reciclados mistos como material para sub-bases de pavimentos (POON e CHAN, 2006). Os resultados indicaram que o agregado reciclado de concreto tem umidade ótima maior e peso específico aparente seco máximo menor que uma brita graduada simples. Os corpos-de-prova de agregado reciclado de concreto apresentaram índice de suporte Califórnia maior que os de agregado reciclado misto. Além disso, concluiu-se que os valores de índice de suporte Califórnia obtidos com ensaios imersos e não-imersos não apresentaram diferenças significativas (POON e CHAN, 2006). 


\subsubsection{Pavimentação com agregado reciclado no Brasil}

A primeira via com resíduo da construção civil na cidade de São Paulo foi pavimentada no ano de 1984. A Rua Gervásio da Costa, que se localiza na zona oeste da cidade, recebeu o resíduo da construção civil em sua camada de reforço de subleito. A construção teve acompanhamento executivo e de desempenho pelo IPT (Instituto de Pesquisas Tecnológicas do Estado de São Paulo). Na época a via apresentou desempenho altamente satisfatório (BODI et al., 1995).

No início da década de 90 na cidade de São Paulo, foi implementado um programa de reciclagem de resíduos da construção civil para fins de pavimentação. Foram realizados estudos laboratoriais e concluiu-se que o uso de resíduos de construção e demolição apresentava-se como uma promissora e interessante alternativa para uso em pavimentação urbana (BODI et al., 1995).

A Prefeitura Municipal de Belo Horizonte executa desde 1996 pavimentos com agregados reciclados de resíduo sólido da construção civil em suas camadas de base e sub-base (FERNANDES, 2004). O dimensionamento da estrutura é baseado no índice de suporte Califórnia dos materiais e na experiência prática de engenheiros do município. Belo Horizonte possui uma política de gerenciamento de resíduos diferenciada. $\mathrm{O}$ agregado reciclado é produzido pela própria prefeitura, por meio de três estações de reciclagem de resíduos da construção civil. São produzidos dois tipos de materiais:

- Tipo A: compostos basicamente de concreto e argamassas;

- Tipo B: composto por materiais mistos, como cerâmica, concreto, argamassa e outros.

Muitas vias urbanas de Belo Horizonte foram construídas com os agregados reciclados produzidos pela própria prefeitura e apresentam-se em condições de tráfego semelhantes àqueles trechos com agregados convencionais. Contudo, não se pode afirmar se houve, ou não, um superdimensionamento das camadas do pavimento, uma vez que, como citado antes, contou-se apenas com a experiência 
laboratorial e executiva dos engenheiros da Prefeitura de Belo Horizonte (FERNANDES, 2004).

No fim da década de 90, Trichês e Kryckyj (1999) desenvolveram um estudo para reaproveitamento dos resíduos da construção civil de Florianópolis em pavimentação. Foram estudados dois materiais provenientes de resíduos e dois solos:

- Entulho branco: principalmente compostos por materiais cimentícios, como argamassas, concreto e pequena quantidade de gesso;

- Entulho vermelho: composto por tijolos, telhas e cerâmicas;

- Solo areno-siltoso;

- Solo argiloso.

Conduziram-se ensaios para avaliar as características físicas e a capacidade de suporte do resíduo, do solo e de misturas solo-resíduo, variando a porcentagem da composição. Os resultados indicaram que os resíduos de construção e demolição possuíam expansão nula e contribuíam para a queda da expansão nas misturas com solo. Contudo, foram observados valores menores de índice de suporte Califórnia para os resíduos em relação às misturas solo-resíduo. Os autores acreditam que a incorporação da parcela fina dos solos ao resíduo de construção proporcionou uma melhor compactação, implicando em aumento da capacidade de suporte (TRICHÊS e KRYCKYJ, 1999).

Na Bahia, Carneiro et al. (2001) pesquisaram a viabilidade do emprego de agregados reciclados de Salvador em pavimentação. Foram estudados agregados reciclados nas frações graúda e miúda, e misturas de solos com agregados reciclados em diferentes proporções. Conduziram-se ensaios de caracterização física e mecânica, como análise granulométrica, abrasão Los Angeles, compactação e índice de suporte Califórnia. Os resultados obtidos com a pesquisa indicaram que o agregado reciclado de Salvador é um material adequado à aplicação em bases e sub-bases de pavimentos. 
A partir do ano 2000, a Secretaria de Serviços Urbanos da cidade de Uberlândia e a Universidade Federal de Uberlândia realizaram um estudo para definir parâmetros que permitissem a utilização de resíduos da construção civil em camadas de pavimentos urbanos. Foi construída em 2003 uma pista experimental utilizando agregado reciclado na camada de base. A pista possui expressiva solicitação em termos de tráfego, pois serve de acesso a um aterro sanitário da cidade. Após três anos de funcionamento, não era possível observar defeitos no pavimento por meio de avaliações visuais (MOREIRA et al., 2006).

Agregados reciclados brancos e vermelhos foram estudados em laboratório por Ribeiro et al. (2002) para aplicação em pavimentação na cidade de Goiânia. Os agregados foram britados em laboratório, adequando os materiais às faixas especificadas pelo Departamento Nacional de Estradas de Rodagem (DNER). Também foi analisado o comportamento dos agregados reciclados misturados com solo. Foram realizados ensaios de compactação e índice de suporte Califórnia. Segundo os autores, verificou-se com os resultados obtidos que a utilização de agregados reciclados em pavimentação é tecnicamente viável.

Ainda em Goiânia, entre 2003 e 2004 foi construído um trecho experimental de 50 metros empregando uma mistura de solo argiloso com agregado reciclado nas camadas de base (75\% de agregado reciclado) e sub-base (83\% de agregado reciclado). A pista apresenta considerável tráfego de caminhões, pois é um acesso à central de abastecimento da cidade. O controle tecnológico do segmento compreendeu a realização dos ensaios de frasco de areia, densímetro nuclear e pressiômetro Pencel. O controle de compactação indicou que o densímetro nuclear apresentou valores de umidade e de peso específico de campo maiores que os obtidos em estufa e com o frasco de areia. O pressiômetro Pencel teve o objetivo de medir as propriedades de deformação dos materiais. Os resultados indicaram que o módulo de recarregamento e a pressão limite são considerados bons parâmetros para avaliar o comportamento das camadas do pavimento. Por meio da construção deste trecho experimental foi constatada a viabilidade técnica de emprego do agregado reciclado em pavimentos flexíveis (MENDES et al., 2004). 
Com relação às propriedades mecânicas, Fernandes (2004) estudou em laboratório agregados reciclados de concreto e misto provenientes do Rio de Janeiro e de Belo Horizonte. Os materiais foram analisados para possível aplicação em bases, subbases e reforços de subleito de pavimentos, comparando-os com materiais convencionalmente empregados. Também foram realizados ensaios com a finalidade de verificar possíveis danos ambientais, como lixiviação e solubilização.

Conforme apresentado nas conclusões do capítulo de análise dos ensaios de módulo de resiliência do trabalho de Fernandes (2004), a granulometria do agregado reciclado e a energia de compactação empregada influenciam pouco nos módulos de resiliência. O principal responsável pela diferenças nos valores de módulo de resiliência é a composição do agregado reciclado. No caso estudado, os agregados de concreto apresentaram módulos superiores aos agregados mistos. Além disso, os materiais convencionais analisados (brita graduada simples) apresentaram valores de módulos de resiliência superiores aos agregados reciclados.

O estudo do comportamento mecânico realizado por Fernandes (2004) também compreendeu ensaios triaxiais com cargas repetidas para medir a deformação permanente dos agregados reciclados. Os resultados indicaram que a granulometria e a energia de compactação influenciam na deformação permanente do material. Para o mesmo nível de tensões, a brita graduada simples analisada apresentou deformação permanente superior a dos agregados reciclados.

Os ensaios de lixiviação de Fernandes (2004) atenderam aos limites prescritos pelas normas. No entanto, os ensaios de solubilização indicaram que os agregados reciclados eram materiais pertencentes à Classe II, ou seja, não inertes. Foram observadas as presenças de:

- Alumínio: 0,290mg/l e 0,400mg/l para agregados do Rio de Janeiro e Belo Horizonte, respectivamente. O limite máximo permitido é de $0,200 \mathrm{mg} / 1$, para ser considerado um material inerte (Classe III); 
- Fenóis: 0,004mg/l para agregados do Rio de Janeiro. O limite máximo é $0,001 \mathrm{mg} / 1$, para ser considerado um material inerte (Classe III);

- Selênio: 0,020mg/l para agregados de Belo Horizonte. O limite máximo é $0,010 \mathrm{mg} / \mathrm{l}$, para ser considerado um material inerte (Classe III).

Materiais não inertes não devem ser empregados em camadas de pavimentos em função do risco de contaminação de solos e de águas subterrâneas. No entanto, Fernandes (2004) conclui que estes valores não inviabilizam o uso destes agregados reciclados, pois normalmente o lençol freático no Brasil está abaixo do nível do terreno e o pavimento possui um sistema de drenagem projetado para protegê-lo contra a ação da água.

$\mathrm{Na}$ cidade de Manaus, em função da escassez de material pétreo na região, foi desenvolvida uma pesquisa verificando a possibilidade de emprego de agregado reciclado em concreto asfáltico. Frota et al. (2003) conduziram ensaios de caracterização do ligante asfáltico (CAP 20) e do agregado reciclado (isento de materiais cerâmicos e gesso). A dosagem da mistura asfáltica foi feita pelo método Marshall. Foram moldados corpos-de-prova com diferentes proporções de agregado reciclado $(50 \%$ e $60 \%)$ e corpos-de-prova com $100 \%$ de seixo rolado, que seria o material comumente empregado. Também foram utilizados em todos os corpos-deprova areia e cimento (como filer). Os resultados da dosagem indicaram que o uso do agregado reciclado implica no aumento do teor de ligante, em função de sua maior porosidade. Foram observados os seguintes teores ótimos de asfalto: para o seixo rolado $5,5 \%$, para $50 \%$ de agregado reciclado $6,4 \%$, e para $60 \%$ de agregado reciclado $6,5 \%$. A pesquisa conclui que a utilização do agregado reciclado em concreto asfáltico é tecnicamente viável, contudo o aumento do teor de ligante pode desestimular o emprego destas misturas (FROTA et al., 2003). Entretanto, o trabalho não compreendeu um estudo de durabilidade quanto à ação da água e outros fatores decisivos para comprovar a viabilidade técnica em misturas asfálticas.

Motta (2005) estudou agregados reciclados mistos de São Paulo para aplicação em vias de baixo volume de tráfego. Foram moldados corpos-de-prova de agregado 
reciclado in natura (sem adição de cal ou cimento), de agregado reciclado com cal (4\%) e de agregado reciclado com cimento (4\%). Foram conduzidos ensaios de índice de suporte Califórnia (apenas para no agregado reciclado in natura), módulo de resiliência, resistência à tração por compressão diametral e resistência à compressão simples para o agregado reciclado e para uma brita graduada simples na mesma granulometria. Além disso, todos os ensaios tiveram corpos-de-prova submetidos a diferentes tempos de cura.

Os valores de índice de suporte Califórnia do agregado reciclado in natura aumentaram significativamente com o tempo de cura. Tomando-se como parâmetro de comparação os valores médios, verificou-se que o índice de suporte Califórnia aos 28, 90 e 180 dias de cura cresceram cerca de $24 \%$, 55\% e 67\%, respectivamente, em relação ao resultado obtido para o material sem cura prévia. Além disso, após 90 e 180 dias de cura (com índice de suporte Califórnia igual a 116\% e 124\%, respectivamente), o agregado reciclado apresentou valores superiores ao da brita graduada simples (com índice de suporte Califórnia igual a 96\%) (MOTTA, 2005).

Por outro lado, os ensaios de resistência à tração por compressão diametral e resistência à compressão simples para o agregado reciclado in natura apresentaram ganhos praticamente imperceptíveis com o aumento do tempo de cura: a resistência a tração por compressão diametral manteve-se em $0,01 \mathrm{MPa}$ e a resistência à compressão simples em 0,40MPa. Os corpos-de-prova que tiveram a adição de cimento ou cal tiveram resultados notavelmente maiores que os de agregado reciclado in natura. A resistência à tração por compressão diametral obtida aos 180 dias de cura foi de $0,41 \mathrm{MPa}$ e $0,20 \mathrm{MPa}$, para corpos-de-prova com adição de cimento e cal, respectivamente. Com relação à resistência à compressão simples, verificou-se aos 180 dias de cura 4,00MPa e 3,22MPa, para corpos-de-prova com adição de cimento e cal, respectivamente (MOTTA, 2005).

Com relação ao módulo de resiliência, o agregado reciclado in natura aos 90 dias de cura teve valores semelhantes ao da brita graduada simples. Para uma tensão-desvio de $0,20 \mathrm{MPa}$, o módulo de resiliência do agregado reciclado aos 90 dias de cura 
variou entre $190 \mathrm{MPa}$ e $400 \mathrm{MPa}$, de acordo com a tensão de confinamento aplicada. Nas mesmas condições, o módulo de resiliência da brita graduada simples, ficou entre $200 \mathrm{MPa}$ e $370 \mathrm{MPa}$, de acordo com a tensão de confinamento aplicada. Já os corpos-de-prova com adição de cimento ou cal apresentaram módulos de resiliência muito superiores ao do agregado reciclado in natura. Submetido a uma tensão-desvio de $0,20 \mathrm{MPa}$, os módulos de resiliência ficaram entre $900 \mathrm{MPa}$ e $1900 \mathrm{MPa}$, para corpos-de-prova de agregado reciclado com cal, e entre $1100 \mathrm{MPa}$ e $2100 \mathrm{MPa}$, para corpos-de-prova de agregado reciclado com cimento (MOTTA, 2005).

Em conseqüência do ganho de resistência e da redução de deformabilidade observados, Motta (2005) realizou o ensaio de Chapelle modificado para identificar a atividade pozolânica do agregado reciclado misto. O ensaio de Chapelle modificado baseia-se no consumo de óxido de cálcio $(\mathrm{CaO})$, sendo que para ser considerado uma pozolana, o material deve apresentar um índice de consumo de $\mathrm{CaO}$ de pelo menos 330mg. Os resultados obtidos indicaram um consumo de aproximadamente 130mg de $\mathrm{CaO}$. Apesar do valor obtido estar abaixo do limite, Motta (2005) relata que o ensaio é normalmente empregado para concretos e esta atividade pozolânica pode não ser considerada baixa para emprego em pavimentos. Este fator influi positivamente no uso do agregado reciclado em pavimentação.

\subsubsection{Normalização internacional e nacional}

A publicação das primeiras normas brasileiras relacionadas aos agregados reciclados de resíduo sólido da construção civil ocorreu em 2004. A ABNT publicou quatro normas que tratam desde a instalação para recebimento de resíduos da construção civil até sua aplicação em pavimentos. As normas nacionais são:

- NBR 15113 (2004): Resíduos sólidos da construção civil e resíduos inertes Aterros - Diretrizes para projeto, implantação e operação;

- NBR 15114 (2004): Resíduos sólidos da construção civil e resíduos inertes Área de reciclagem - Diretrizes para projeto, implantação e operação;

- NBR 15115 (2004): Agregados reciclados de resíduos sólidos da construção civil - Execução de camadas de pavimentação - Procedimentos; 
- NBR 15116 (2004): Agregados reciclados de resíduos sólidos da construção civil - Utilização em pavimentação e preparo de concreto sem função estrutural - Requisitos.

A norma empregada neste trabalho é a NBR 15115 (ABNT, 2004), que especifica como devem ser executados pavimentos que empregam o agregado reciclado. $\mathrm{O}$ ensaio de índice de suporte Califórnia é o principal critério de avaliação para emprego dos agregados reciclados em camadas de base, sub-base e reforço do subleito.

Antes da norma da ABNT, foi publicada no ano de 2003 a especificação técnica de serviço da Prefeitura do Município de São Paulo (PMSP), PMSP/SP ETS-001 (PMSP, 2003), que também define critérios para orientar a execução de camadas de pavimento com o agregado reciclado. A PMSP/SP ETS-001 (PMSP, 2003) considera o valor do índice de suporte Califórnia como principal parâmetro para a utilização de agregados reciclados em pavimentos e é um pouco mais rígida em relação às propriedades físicas dos agregados reciclados, comparada à NBR 15115 (ABNT, 2004).

Para empregar o agregado reciclado em camadas de pavimentos, é importante conhecer as especificações existentes e respeitá-las. Atualmente nos Estados Unidos 28 estados permitem o uso do agregado reciclado de concreto como material para base e sub-base e somente 15 destes estados possuem especificações para o uso destes agregados reciclados (KUO et al., 2002).

Em termos de normalização internacional sobre o uso de agregado reciclado em pavimentação, não foram encontradas muitas referências na bibliografia consultada. As normas ou especificações observadas são (LEVY, 2001; NATAATMADJA e TAN, 2001; KUO, 2002; MOTTA, 2005):

- Norma Britânica - BS 6543 (1985): Guide to use of industrial by-products and waste materials in building and civil engineering; 
- Especificação técnica holandesa - Standaard RAW bepalingen (1995): Stichting Centrum voor Regelgeving en Onderzoek in de Grond-, Water-en Wegenbouw en de Verkeerstechniek;

- Especificação técnica alemã - TL RC-TOB (1995): Technischen Lieferbedingungen für Recyclingbaustoffe in Tragschichten ohne Bindemittel;

- Especificação técnica do estado de Victoria (Road Authority of Victoria), Austrália - Section 820 (2006): Recycled crushed concrete for pavement subbase and light duty base ${ }^{1}$;

- Especificações técnica dos Departamentos de Transportes dos estados da Florida e Minnesota (FDOT e Mn/DOT).

A elaboração de normas e de especificações técnicas colabora para que seja difundido e consolidado o uso do agregado reciclado em camadas de pavimentos. Pela literatura revisada, observou-se que muitos estudos vêm sendo desenvolvidos em todo o mundo, procurando estabelecer diretrizes para a reciclagem dos resíduos da construção. Os resultados apontam de uma forma geral que o agregado reciclado possui um grande potencial para emprego em pavimentação, proporcionando uma série de benefícios ambientais, econômicos e sociais.

\footnotetext{
${ }^{1}$ Disponível em:

<http://webapps.vicroads.vic.gov.au/VRNE/vrbscat.nsf/CatalogByCategory/2569E59FD63355ABCA 


\section{ESTUDO DE CASO: PAVIMENTO DO SISTEMA VIÁRIO DA USP LESTE}

\subsection{Localização e justificativa}

O Laboratório de Tecnologia de Pavimentação da Escola Politécnica teve a oportunidade de conceber e projetar em 2004 o pavimento do sistema viário do novo campus da Universidade de São Paulo. O novo campus, denominado USP Leste, está localizado na zona leste do município de São Paulo.

Para o sistema viário da USP Leste, foi proposta a construção de um pavimento que utilizasse materiais reciclados na sua estrutura: agregado reciclado de resíduo sólido da construção civil e cimento asfáltico com borracha moída de pneus inservíveis (asfalto-borracha). A motivação para a construção de um pavimento com estes materiais alternativos e reciclados deveu-se aos seguintes fatores:

- O campus da USP Leste está situado na região do Parque Ecológico do Tietê;

- A USP Leste oferece um curso de graduação em gestão ambiental;

- Importância da seleção de uma alternativa que tivesse em sua concepção a preocupação com o meio ambiente;

- A universidade é uma das instituições responsáveis pelo desenvolvimento de soluções inovadoras para a sociedade.

Além destes fatores, objetivava-se que o pavimento do sistema viário da USP Leste se tornasse um exemplo para novas experiências, contribuindo para a consolidação do uso destes materiais reciclados.

O grande diferencial do pavimento do sistema viário da USP Leste é o emprego do agregado reciclado de resíduo sólido da construção civil nas camadas de base e subbase em solução conjunta com o concreto asfáltico com asfalto-borracha na camada de rolamento.

O sistema viário do campus da USP Leste possui aproximadamente dois quilômetros, considerando vias internas e estacionamentos, e foi construído em duas etapas. $\mathrm{Na}$ 
primeira etapa foram construídos 240 metros, entre dezembro de 2004 e março de 2005. A segunda etapa da obra, que concluiu a construção dos dois quilômetros, foi realizada entre agosto de 2005 e março de 2006. Estes períodos correspondem em sua grande parte ao período de chuvas em São Paulo, o que dificultou e atrasou a construção do pavimento.

Neste trabalho são apresentados e discutidos os resultados do controle tecnológico realizado em 1.020 metros de extensão da via principal, onde foram utilizadas aproximadamente 5.000 toneladas de agregado reciclado. Nos ANEXOS deste trabalho é apresentado o croqui da USP Leste, ilustrando o trecho do sistema viário estudado.

\subsection{Dimensionamento do pavimento}

A maior dificuldade na implantação do sistema viário do campus da USP Leste foi o fato do local ser um antigo "bota-fora" de solo retirado do subleito da Rodovia Airton Senna (SP 070), durante sua construção. O material foi disposto de forma não controlada e não foi compactado. Assim, o subleito do campus da USP Leste é muito variável, apresentando solos de baixa capacidade de suporte, expansivos e pouco permeáveis assentes sobre solo mole. Além do aterro constituído de solo de baixa resistência, toda a região do campus fica na várzea do Rio Tietê, com solo mole orgânico abaixo do aterro com espessura variando de 1 a 4 metros. A Figura 3.1 ilustra o subleito da USP Leste. 


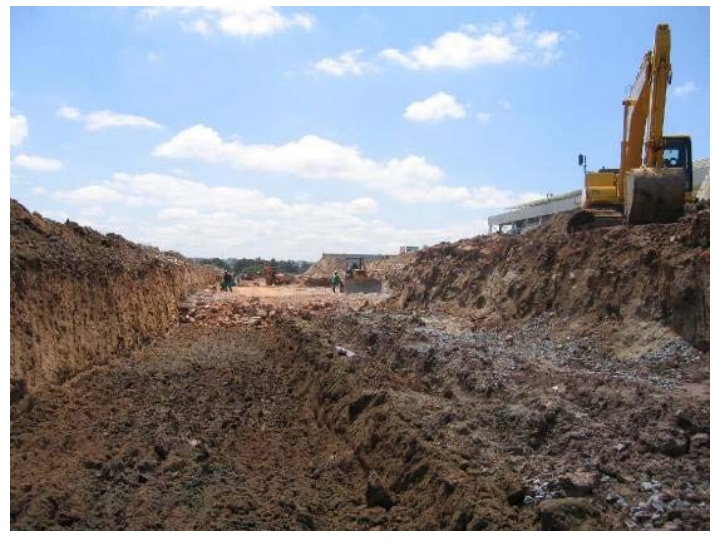

(a)

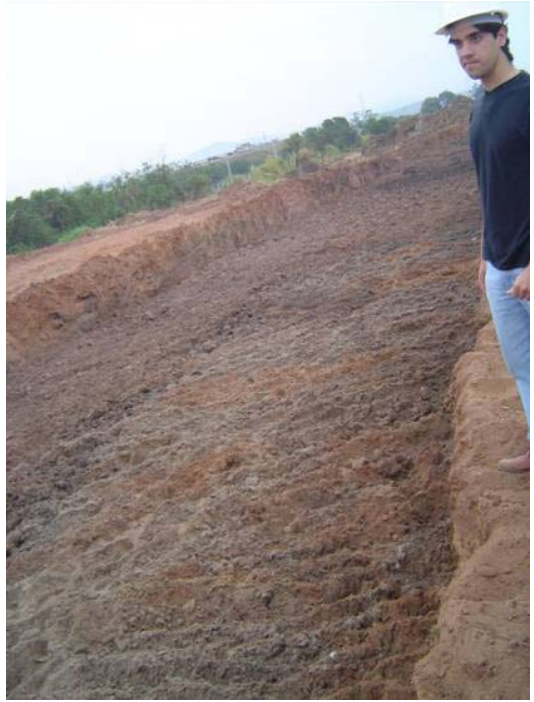

(b)

Figura 3.1: Subleito da USP Leste

O dimensionamento do pavimento seguiu o método do DNER para pavimentos flexíveis (DNIT, 2006) e foi verificado por método teórico, empregando o programa computacional ELSYM5. Este programa permite uma análise mecanicista por meio do cálculo das tensões, deformações e deslocamentos por diferenças finitas, considerando a hipótese de elasticidade linear.

De acordo com os relatórios de sondagem, o índice de suporte Califórnia do solo de fundação da USP Leste é baixo, em torno de 3\%. Assim, optou-se por uma estrutura de pavimento robusta, mesmo tendo um volume de tráfego baixo $\left(\mathrm{N}<10^{6}\right.$, repetições de carga de $80 \mathrm{kN}$ de eixo simples de roda dupla).

A concepção básica do pavimento projetado possui quatro camadas sobre o subleito: reforço de subleito, sub-base, base e revestimento asfáltico. No entanto, o sistema viário da USP Leste teve, após sua implantação, quatro seções-tipo de pavimento executadas, que são ilustradas na Figura 3.2. 

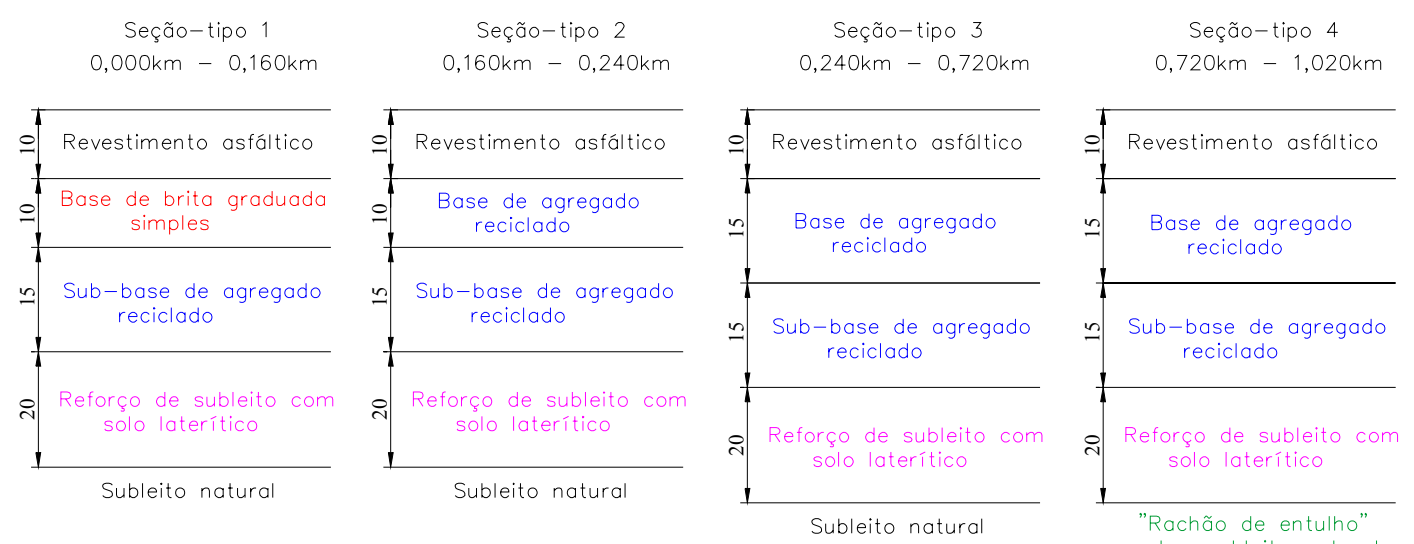

Figura 3.2: Quatro seções-tipo de pavimento executadas no sistema viário da USP Leste, com cotas em cm

De acordo com o projeto, foi especificado que o revestimento asfáltico deveria ter $10 \mathrm{~cm}$ e ser composto por duas camadas: uma intermediária do tipo binder e uma de rolamento. Esta espessura de revestimento é grande para um volume de tráfego baixo, como o do campus da USP Leste. No entanto, optou-se pelo emprego de um binder mais aberto como camada de comportamento intermediário entre a camada de rolamento e a base, em função da incerteza de comportamento adequado do agregado reciclado na camada de base. O emprego do asfalto-borracha na camada de rolamento teve como objetivo proporcionar uma maior flexibilidade no revestimento, permitindo maiores deslocamentos sem trincar e aumentando a durabilidade da estrutura em relação à fadiga. Esta flexibilidade foi considerada um fator muito importante no projeto do pavimento da USP Leste, uma vez que o subleito do sistema viário tem baixa capacidade de suporte e o comportamento do agregado reciclado levava ainda a incertezas de comportamento estrutural.

Para as camadas de base e sub-base, deveriam ser empregados agregados reciclados de resíduo sólido da construção civil, provenientes de usinas recicladoras. Estes materiais deveriam estar de acordo com a NBR 15115 (ABNT, 2004), exceto quanto ao diâmetro característico máximo, que foi de $50 \mathrm{~mm}$, como o adotado pela PMSP/SP ETS-001 (PMSP, 2003). Contudo, durante a primeira etapa de obras foi construído um segmento com agregado reciclado na camada de sub-base e brita graduada simples na base (seção-tipo 1 - Figura 3.2). Este trecho possui 160 metros e foi um bom comparativo de comportamento entre a brita graduada simples e o agregado 
reciclado, já que a utilização do material reciclado é proposta em substituição aos materiais não-renováveis.

Para a camada de reforço de subleito, foi especificado em projeto que fosse utilizado solo importado, com características geotécnicas de solo laterítico e índice de suporte Califórnia de no mínimo 10\%. Como o subleito da USP Leste é altamente deformável, a camada de reforço de subleito teve a importante função de dar suporte para a execução da camada de sub-base de agregado reciclado, distribuindo melhor os esforços oriundos do tráfego.

Ainda no primeiro período de construção, foi executada uma segunda seção-tipo (seção-tipo 2 - Figura 3.2) empregando o agregado reciclado tanto na camada de base, como de sub-base. Este segmento possui 80 metros e as mesmas espessuras das camadas da seção-tipo 1 .

Na segunda etapa de obras, o pavimento executado possui a mesma concepção da segunda seção-tipo, com base e sub-base de agregado reciclado. Contudo, a espessura da camada de base é maior, com 150mm. A seção-tipo 3 possui 480 metros de extensão (Figura 3.2).

A necessidade de uma quarta seção-tipo surgiu porque durante a obra houve problemas geométricos na implantação. Assim, foi necessário remover em um segmento de 300 metros a camada superior de solo do aterro, atingindo o solo mole. Dessa forma, foi utilizado sobre a camada final de terraplenagem um material denominado por "rachão de entulho", originando a seção-tipo 4 (Figura 3.2).

\subsection{Materiais empregados}

As características e a proveniência de cada material empregado nas camadas do pavimento do sistema viário da USP Leste são apresentadas em cinco itens: (i) concreto asfáltico, (ii) brita graduada simples, (iii) solo laterítico para reforço de subleito, (iv) "rachão de entulho", e (v) agregado reciclado de resíduo sólido da construção civil. 


\subsubsection{Concreto asfáltico}

O revestimento asfáltico é composto por duas camadas: uma intermediária de prémisturado a quente (tipo binder) com CAP 20 e granulometria na faixa II da PMSP; e uma de rolamento em concreto asfáltico com asfalto-borracha com granulometria na faixa III da PMSP. As faixas são apresentadas na Figura 3.3.

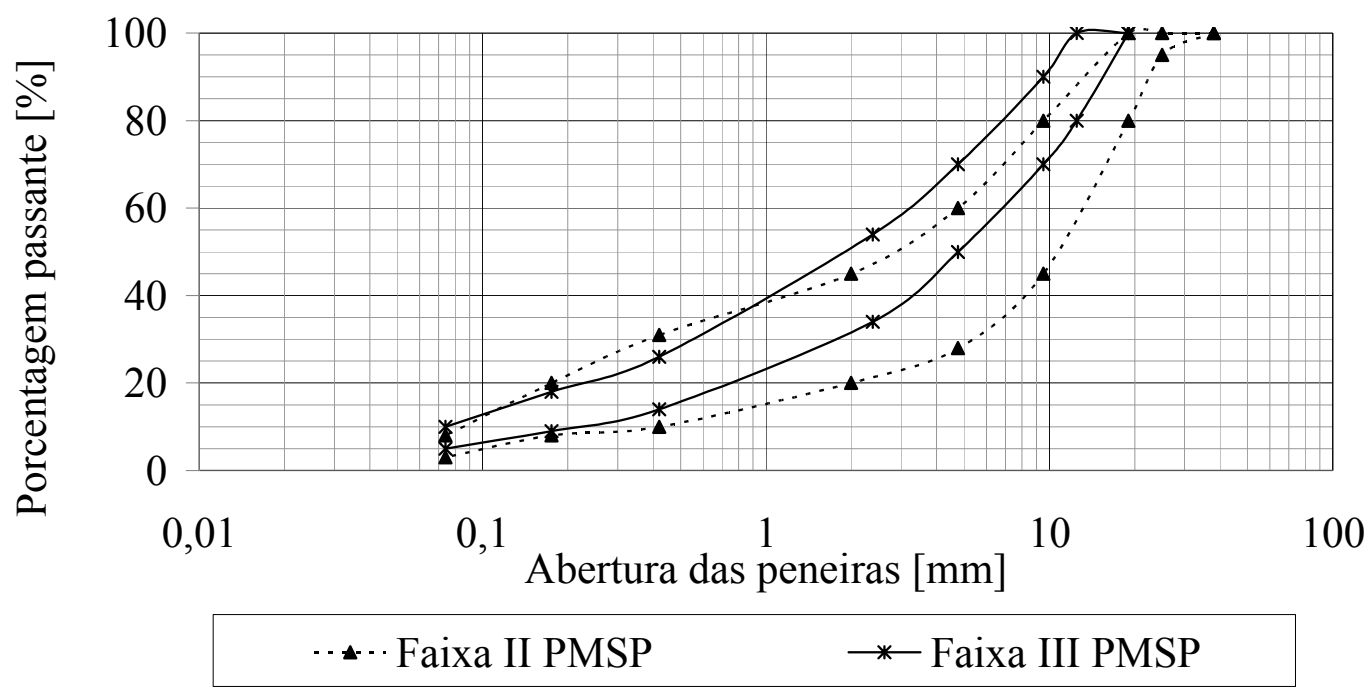

Figura 3.3: Limites da faixa II (camada intermediária) e da faixa III (camada de rolamento) da PMSP utilizadas no revestimento asfáltico do pavimento do sistema viário da USP Leste

Durante a primeira etapa de obras, quando foram construídos inicialmente os 240 metros de extensão de vias, as misturas asfálticas foram produzidas numa usina localizada na cidade de Guarulhos, região metropolitana de São Paulo. Os agregados empregados eram de origem granítica. $\mathrm{O}$ asfalto-borracha utilizado neste trecho foi fornecido pela empresa Greca Distribuidora de Asfalto Ltda. Na segunda etapa de obras, as misturas asfálticas foram fornecidas por uma usina localizada na cidade de São Paulo, com agregados de origem granítica. O asfalto-borracha foi fornecido pela Petrobras Distribuidora S.A. A Figura 3.4 e a Figura 3.5 ilustram o espalhamento da mistura asfáltica e a sua compactação. 


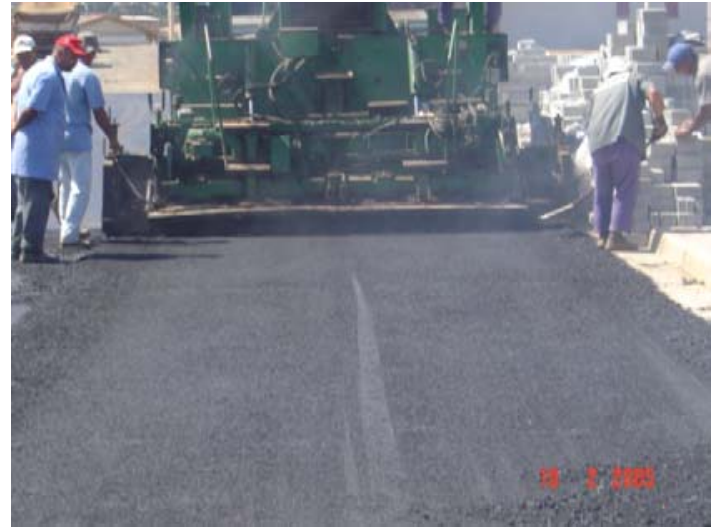

Figura 3.4: Vibroacabadora espalhando a mistura asfáltica

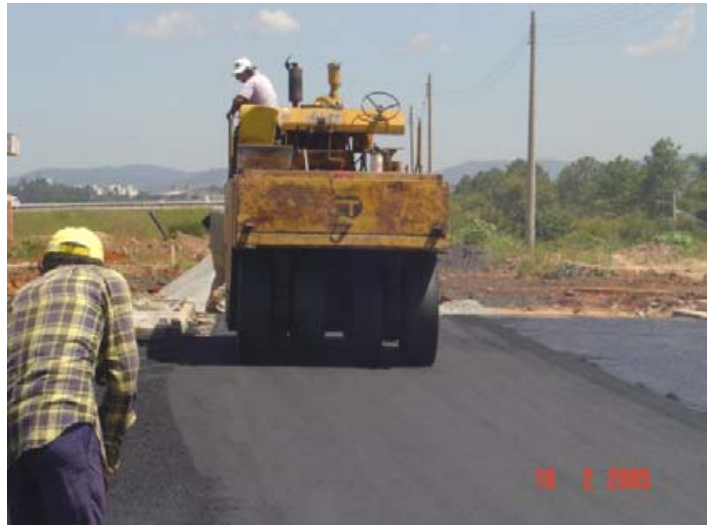

Figura 3.5: Compactação do revestimento asfáltico

Antes de receber o revestimento, sobre a camada de base foi realizada uma imprimação impermeabilizante com CM-30 (asfalto diluído de cura média) e sobre a camada de binder foi aplicada uma pintura de ligação com RR-2C (emulsão asfáltica de ruptura rápida), antes da execução do concreto asfáltico. A Figura 3.6 e a Figura 3.7 apresentam a base de agregado reciclado após a imprimação impermeabilizante e a execução da pintura de ligação sobre a camada de binder com caneta espargidora.

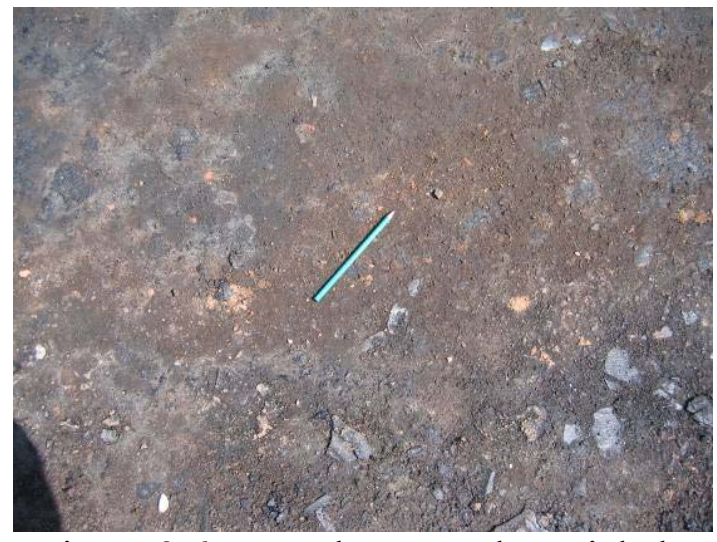

Figura 3.6: Base de agregado reciclado com imprimação impermeabilizante

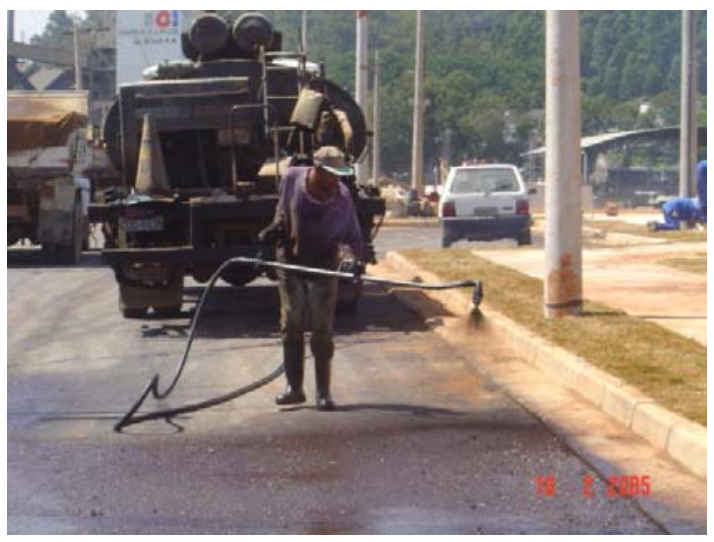

Figura 3.7: Execução da pintura de ligação sobre a camada de binder

\subsubsection{Brita graduada simples}

A brita graduada simples empregada na seção-tipo 1 (Figura 3.2) foi proveniente da Pedreira Vila Galvão localizada no município de Guarulhos, região metropolitana de São Paulo. Sua aplicação foi realizada sobre a camada de sub-base de agregado reciclado (Figura 3.8). 


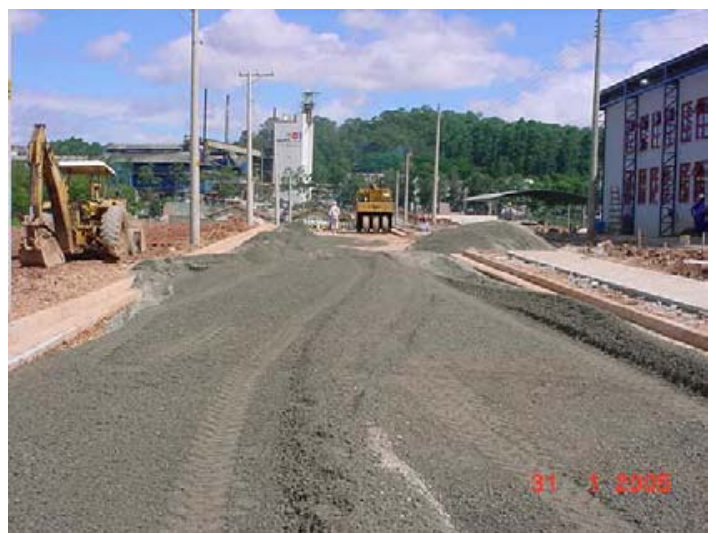

Figura 3.8: Camada de base de brita graduada simples sendo executada

Não foi especificada a faixa granulométrica da brita graduada simples empregada. Contudo, a Figura 3.9 apresenta a granulometria da brita graduada simples juntamente com os limites da Faixa I da PMSP.

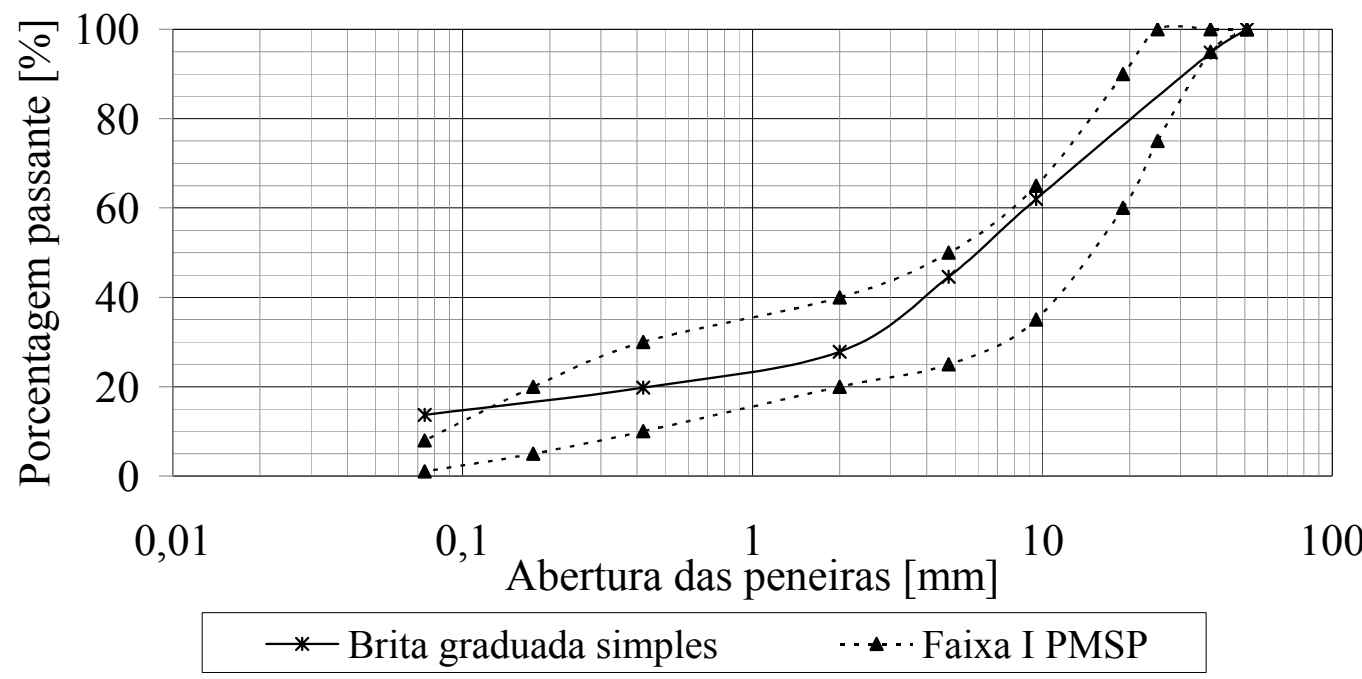

Figura 3.9: Granulometria da brita graduada simples empregada na seção-tipo 1 do pavimento do sistema viário da USP Leste

Foi conduzido pela empresa fiscalizadora da obra o ensaio de compactação e o de índice de suporte Califórnia na energia intermediária com a brita graduada simples aplicada na obra. Os resultados obtidos são apresentados na Tabela 3.1. 
Tabela 3.1: Características da brita graduada simples empregada na seção-tipo 1 do pavimento do sistema viário da USP Leste

\begin{tabular}{|c|c|c|c|c|}
\hline Material & $\begin{array}{c}\text { Diâmetro } \\
\text { característico } \\
\text { máximo } \\
{[\mathrm{mm}]}\end{array}$ & $\begin{array}{c}\text { Umidade } \\
\text { ótima [\%] }\end{array}$ & $\begin{array}{c}\text { Peso } \\
\text { específico } \\
\text { aparente seco } \\
\text { máximo } \\
{\left[\mathrm{kN} / \mathrm{m}^{3}\right]}\end{array}$ & $\begin{array}{c}\text { Índice de suporte } \\
\text { Califórnia } \\
{[\%]}\end{array}$ \\
\hline $\begin{array}{c}\text { Brita graduada } \\
\text { simples }\end{array}$ & 50,0 & 5,7 & 22,8 & 90 \\
\hline
\end{tabular}

A camada de base com brita graduada simples foi compactada com $95 \%$ da energia modificada, seguindo a especificação de projeto.

\subsubsection{Solo laterítico para reforço de subleito}

De acordo com as seções-tipo apresentadas na Figura 3.2, o pavimento projetado possui acima da camada final de terraplenagem uma camada de reforço de subleito. Foi especificado que esta camada fosse executada com solo importado, de comportamento laterítico e que apresentasse índice de suporte Califórnia de no mínimo $10 \%$ e expansão inferior a $1 \%$.

Os solos foram importados da cidade de São Paulo, região do bairro da Lapa. De acordo com ensaios conduzidos no laboratório o material apresenta comportamento laterítico e é classificado como LG' (laterítico argiloso). Em relação ao índice de suporte Califórnia foram obtidos valores entre $12 \%$ e $17 \%$, para energia normal, e expansão de $0,15 \%$ a $0,30 \%$.

\subsection{4 "Rachão de entulho"}

O "rachão de entulho" foi empregado na seção-tipo 4 (Figura 3.2), sobre a camada de solo mole. Este material é o resíduo bruto de construção e demolição, sem receber tratamentos antes do seu emprego, exceto a retirada por catação de madeiras, plásticos e outros resíduos contaminantes. No caso da USP Leste, foi observada em vários locais a presença de ferro das armaduras das estruturas de concreto demolidas. A Figura 3.10 e a Figura 3.11 ilustram o "rachão de entulho" e a sua aplicação. 


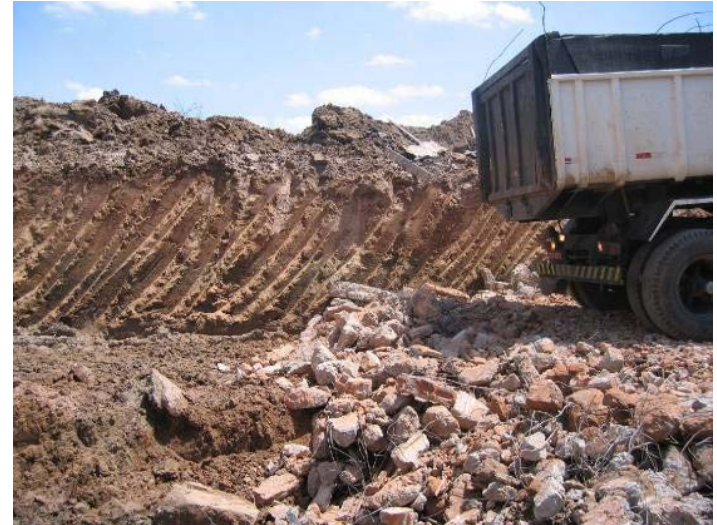

Figura 3.10: "Rachão de entulho" colocado sobre solo mole do subleito do sistema viário da USP Leste

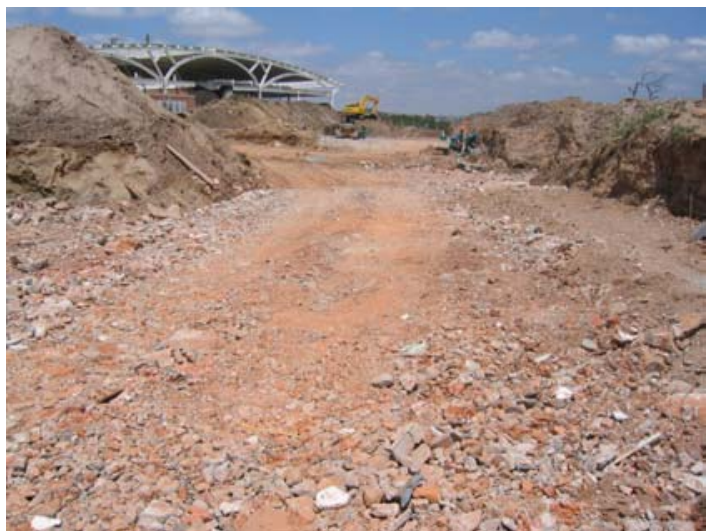

Figura 3.11: Camada de "rachão de entulho"após compactação

O "rachão de entulho" empregado na USP Leste veio da demolição de antigos casarões de São Paulo e da antiga Casa de Detenção de São Paulo, mais conhecida como Carandiru.

\subsubsection{Agregado reciclado de resíduo sólido da construção civil}

Para a construção da extensão de 1.020 metros do sistema viário do campus da USP Leste aqui estudada, foram empregados agregados reciclados de resíduo sólido da construção civil fornecidos por duas usinas recicladoras. Estas usinas são de propriedade privada e estão localizadas na região metropolitana de São Paulo, embora em municípios distintos: Santo André e São Bernardo do Campo.

De acordo com a empresa fiscalizadora da obra, o agregado reciclado utilizado na USP Leste teve um custo inferior em 30\% com relação à brita graduada simples, considerando os gastos com transporte.

Durante a obra, a produção de agregado reciclado pelas usinas recicladoras não foi constante. Na primeira etapa de construção, referente ao trecho de 240 metros iniciais, foi empregado somente material da usina recicladora de Santo André. Na segunda etapa de obras, inicialmente utilizaram-se materiais das usinas de Santo André e São Bernardo do Campo. Entretanto, houve momentos em que a usina recicladora de São Bernardo do Campo não teve produção, sendo dessa forma empregado em maior quantidade o agregado de Santo André. 
Na obra, os agregados foram armazenados em pilhas, como ilustra a Figura 3.12.

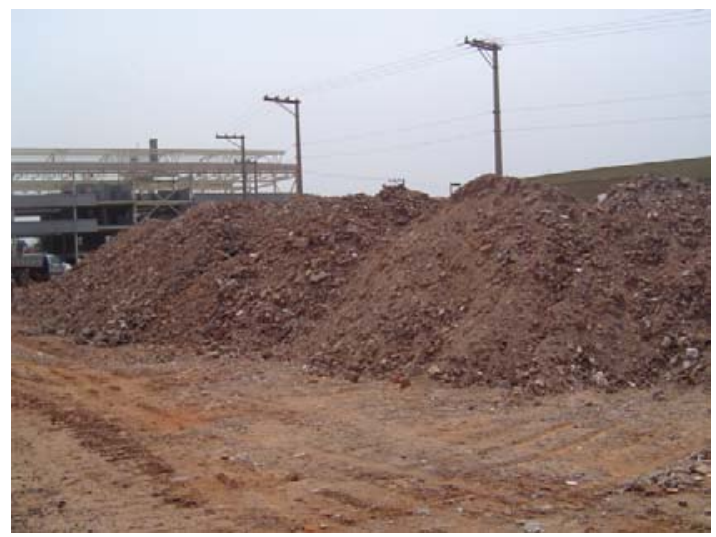

Figura 3.12: Pilha de agregado reciclado armazenada na obra

O requisito para uso do agregado reciclado nas camadas de base e sub-base do pavimento da USP Leste é que o material estivesse de acordo com a NBR 15115 (ABNT, 2004), exceto com relação à dimensão característica máxima. A Tabela 3.2 apresenta os aspectos prescritos pela norma que deveriam ser atendidos.

Tabela 3.2: Aspectos prescritos pela NBR 15115 (ABNT, 2004) com relação às características do agregado reciclado de resíduo sólido da construção civil para emprego em camadas de base e sub-base

\begin{tabular}{|c|c|c|}
\hline Ensaio & \multicolumn{2}{|c|}{ Detalhamento } \\
\hline \multirow{3}{*}{$\begin{array}{l}\text { Análise } \\
\text { granulométrica }\end{array}$} & dimensão característica máxima & $50,0 \mathrm{~mm}^{(\mathrm{a})}$ \\
\hline & coeficiente de uniformidade & maior ou igual a 10 \\
\hline & $\%$ passante na peneira $0,42 \mathrm{~mm}$ & entre $10 \%$ e $40 \%$ \\
\hline \multirow{2}{*}{$\begin{array}{l}\text { Porcentagem de } \\
\text { materiais } \\
\text { indesejáveis }\end{array}$} & mesmo grupo & $2,0 \%$ \\
\hline & grupos distintos & $3,0 \%$ \\
\hline Forma dos grãos & \% de grãos lamelares & máximo $30 \%$ \\
\hline \multirow{2}{*}{$\begin{array}{l}\text { Índice de suporte } \\
\text { Califórnia }\end{array}$} & \multirow{2}{*}{ de acordo com o tipo de camada } & Base: mínimo $60 \%{ }^{(b)}$ \\
\hline & & Sub-base: mínimo $20 \%$ \\
\hline \multirow{2}{*}{ Expansão } & \multirow{2}{*}{ de acordo com o tipo de camada } & Base: máximo $0,5 \%{ }^{(b)}$ \\
\hline & & Sub-base: máximo $1,0 \%$ \\
\hline
\end{tabular}

(a) A NBR 15115 (ABNT, 2004) prescreve como diâmetro característico máximo dos grãos 63,5mm, no caso do pavimento da USP Leste foi utilizado diâmetro característico máximo de $50,0 \mathrm{~mm}$.

(b) É permitido o uso de agregado reciclado em camada de base para vias de tráfego com $\mathrm{N} \leq 10^{6}$ repetições do eixo-padrão de $80 \mathrm{kN}$ no período do projeto. 
Assim, os resultados obtidos com os ensaios foram comparados ao estabelecido na NBR 15115 (ABNT, 2004), com exceção à dimensão característica máxima dos grãos, onde a norma estipula $63,5 \mathrm{~mm}$. Entretanto, o projeto de pavimentação desenvolvido fixou diâmetro característico máximo de 50,0 mm para o agregado reciclado empregado na obra.

Além dos aspectos com relação aos materiais, a NBR 15115 (ABNT, 2004) prescreve que o agregado reciclado deve ser compactado no mínimo com a energia intermediária para a aplicação nas camadas de base e sub-base. O projeto do pavimento da USP Leste exigia que a energia de compactação empregada fosse no mínimo 95\% da modificada. A norma também recomenda que sejam utilizados rolos compactadores do tipo pé-de-carneiro vibratório ou liso vibratório. A Figura 3.13 e a Figura 3.14 ilustram o espalhamento da camada de agregado reciclado com motoniveladora e a sua compactação com rolo liso vibratório.

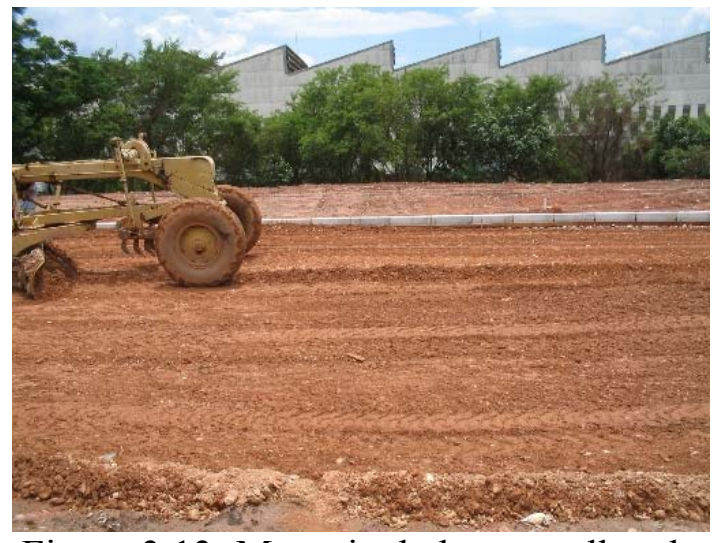

Figura 3.13: Motoniveladora espalhando a camada de agregado reciclado

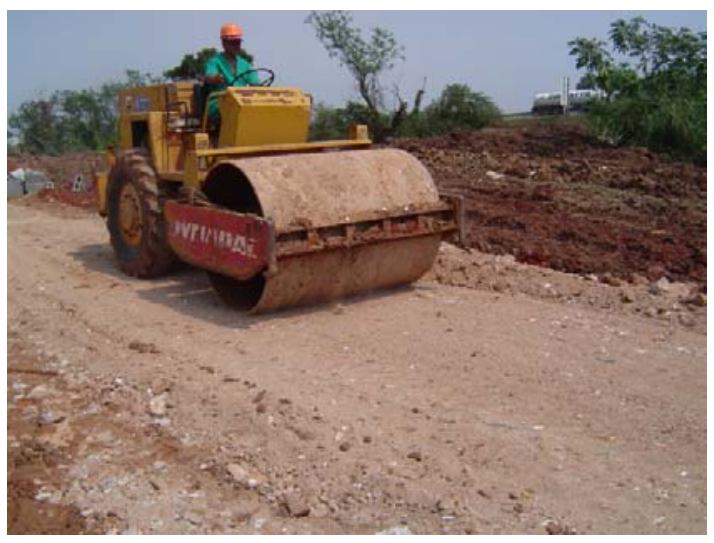

Figura 3.14: Compactação de camada de agregado reciclado

A caracterização física e mecânica dos agregados reciclados empregados no pavimento da USP Leste verificando se atende a NBR 15115 (ABNT, 2004) é apresentada nos itens 4.5 e 5.4 .

\subsection{Problemas ocorridos}

Durante a execução do sistema viário da USP Leste, alguns problemas ocorreram, prejudicando em parte a qualidade final e a análise do pavimento. 
A primeira etapa de obras foi realizada num período de muitas chuvas em São Paulo, entre dezembro e março. Após a execução, foi verificada a presença em alguns pontos isolados de solos "borrachudos". Estes locais tiveram as camadas problemáticas removidas e a estrutura do pavimento foi refeita.

O problema mais sério ocorreu na segunda etapa de obras, entre o segmento $0,260 \mathrm{~km}$ até $0,330 \mathrm{~km}$, correspondente à seção-tipo 3 . Neste trecho de 70 metros a estrutura projetada foi alterada. A empresa construtora empregou, sem consultar os responsáveis pela obra, uma camada de mistura asfáltica fresada sobre a camada de base, antes do binder. Por não se conhecer as propriedades mecânicas deste material fresado, a avaliação mecanicista deste segmento não foi realizada. Este segmento não teve o material fresado removido, ou seja, não foi refeita.

\subsection{Discussão sobre o estudo laboratorial e monitoramento planejados}

A análise do comportamento mecânico de agregado reciclado de resíduo sólido da construção civil em pavimentação é o principal objetivo deste trabalho. Assim, o pavimento construído no campus da USP Leste foi o fundamento desta pesquisa de mestrado.

A metodologia planejada consistiu em duas partes: o estudo laboratorial de amostra de agregado reciclado coletada em campo e o monitoramento do pavimento construído.

Para o desenvolvimento do estudo em laboratório desta pesquisa, o agregado reciclado foi coletado de uma única vez do estoque da obra. A grande distância entre o Laboratório de Tecnologia de Pavimentação da Escola Politécnica da USP e o campus da USP Leste, e o próprio andamento da obra, impossibilitou a coleta diária de amostras. Assim, não foi possível trabalhar em laboratório com diversas amostras representativas do agregado reciclado empregado em campo. Contudo, optou-se por caracterizar e analisar as propriedades da amostra de um único lote, pois esta análise permitiu uma avaliação mecânica do material reciclado quando submetido ao tráfego 
variando algumas propriedades (como energia e tensões aplicadas), mesmo com a possibilidade de variação nas suas características físicas em campo.

Quanto ao monitoramento em campo, a fiscalização prevista na NBR 15115 (ABNT, 2004) foi responsabilidade da empresa fiscalizadora contratada, no caso a Concremat Engenharia e Tecnologia S.A. Além do controle realizado por esta empresa, foram conduzidos para o desenvolvimento deste trabalho ensaios de avaliação estrutural no pavimento. 


\section{PROGRAMA EXPERIMENTAL: LABORATÓRIO E CAMPO}

Neste capítulo é apresentado o agregado reciclado de resíduo sólido da construção civil estudado em laboratório e a metodologia empregada. São expostos igualmente os procedimentos empregados no controle tecnológico do pavimento do sistema viário do campus da USP Leste.

\subsection{Material analisado em laboratório}

O material analisado neste trabalho é o agregado reciclado de resíduo sólido da construção civil empregado no pavimento do campus da USP Leste. Para a realização do estudo laboratorial, foram coletadas de uma única vez aproximadamente duas toneladas de agregado reciclado. Esta amostra estava no estoque da obra e por problemas de fornecimento, encontrava-se disponível no momento apenas material proveniente da usina recicladora de Santo André. Dessa forma, os ensaios em laboratório foram realizados com material de somente uma usina recicladora.

O agregado reciclado de Santo André foi coletado aleatoriamente de uma pilha do estoque com uma pá carregadeira no dia 24 de novembro de 2005, durante a segunda etapa de obras da USP Leste. O material foi colocado em um caminhão e transportado até o Laboratório de Tecnologia de Pavimentação da Escola Politécnica da Universidade de São Paulo (Figura 4.1 e Figura 4.2).

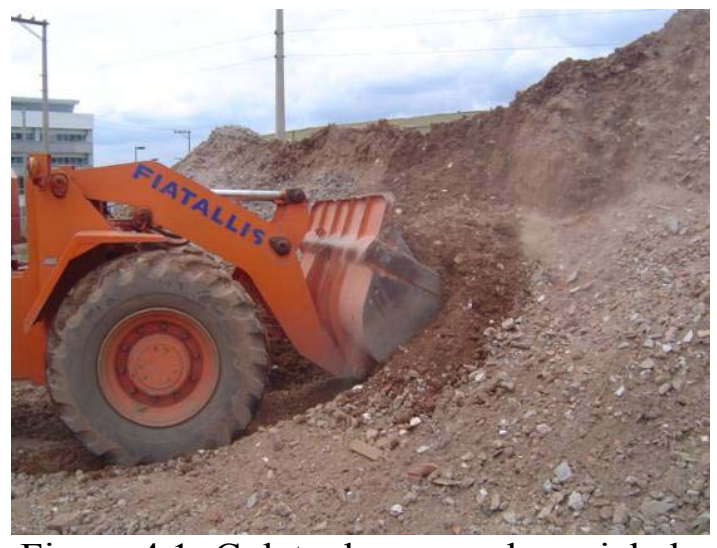

Figura 4.1: Coleta do agregado reciclado com pá carregadeira

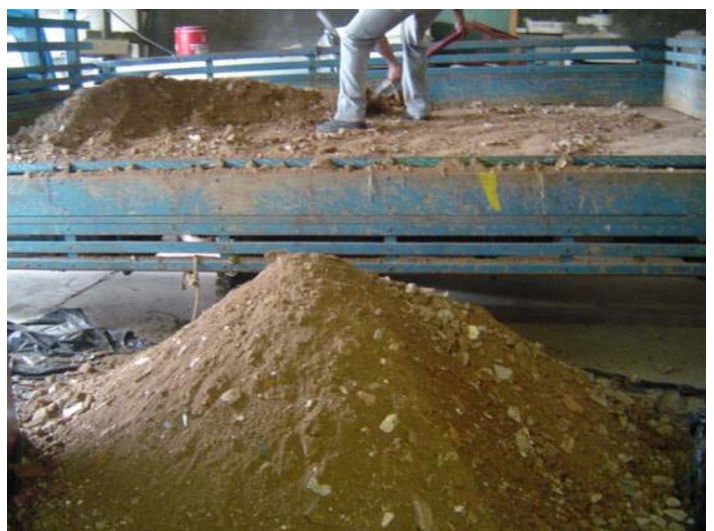

Figura 4.2: Descarregamento do agregado reciclado no laboratório 
Depois de descarregado o material no laboratório, ele foi homogeneizado antes do seu armazenamento (Figura 4.3). Após esta homogeneização, espalhou-se este material de forma que ficasse uma pilha com uma altura de aproximadamente $150 \mathrm{~mm}$ (Figura 4.4).

Em seguida acondicionou-se o agregado reciclado em sacos plásticos de $250 \mathrm{~mm} \mathrm{x}$ $450 \mathrm{~mm}$, para facilitar o armazenamento e manejo das amostras (Figura 4.5). Teve-se muito cuidado durante o ensacamento para que as partes mais finas não fossem perdidas (Figura 4.6) e considerou-se durante a pesquisa cada um destes sacos como uma amostra representativa do material de laboratório, coletado para a realização dos ensaios. Ao final foram obtidos 150 sacos, com aproximadamente $11 \mathrm{~kg}$ cada um.

A umidade do material ensacado encontrava-se em torno de $8,0 \%$.

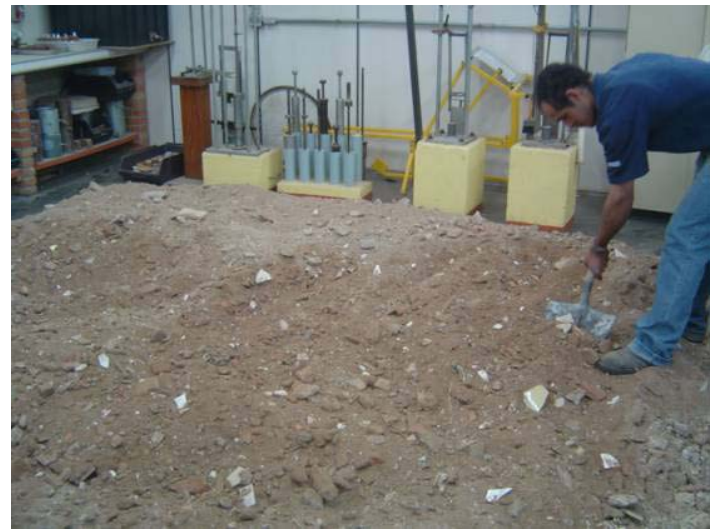

Figura 4.3: Homogeneização do material

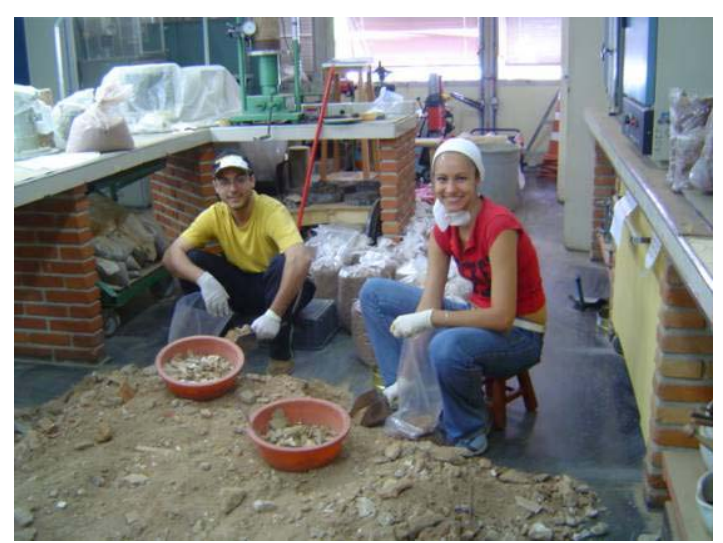

Figura 4.5: Acondicionamento do agregado reciclado em sacos plásticos

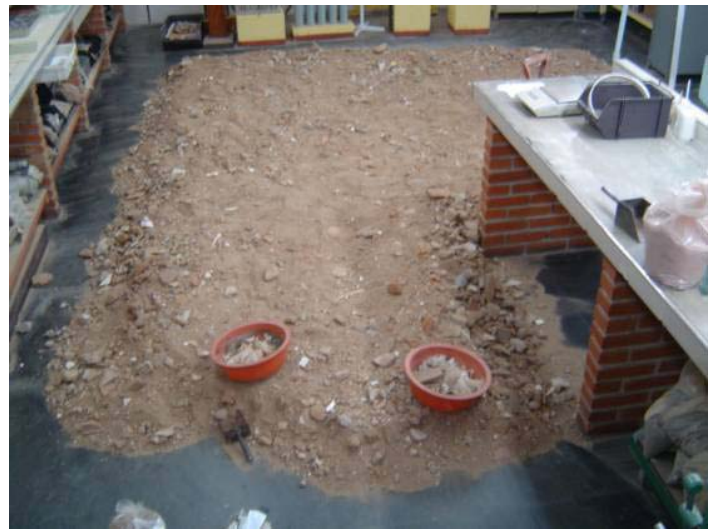

Figura 4.4: Pilha de agregado reciclado no laboratório

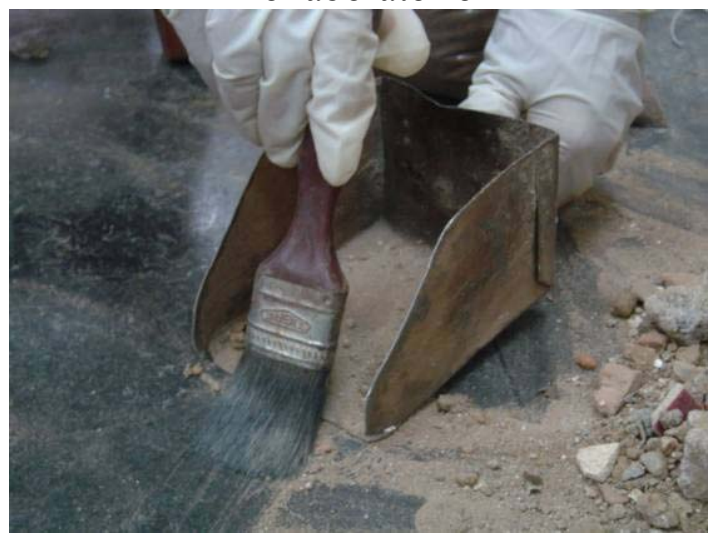

Figura 4.6: Coleta da parte fina 


\subsection{Ensaios de caracterização física em laboratório}

A caracterização física de um material apresenta grande importância, uma vez que o seu comportamento mecânico está relacionado com as suas propriedades físicas. Esta etapa consistiu na determinação em laboratório de seis aspectos físicos do agregado reciclado de Santo André aqui estudado: (i) composição, (ii) materiais indesejáveis, (iii) massa específica dos grãos, (iv) absorção de água, (v) distribuição granulométrica e (vi) forma dos grãos.

\subsubsection{Composição do agregado reciclado}

Determinar a composição do agregado reciclado de resíduo sólido da construção civil é uma etapa muito importante na sua caracterização física. Os diferentes materiais que o constituem influem diretamente em muitas de suas propriedades, tais como resistência mecânica, absorção de água e massa específica (LIMA, 1999). Dessa forma, é possível compreender melhor o comportamento do agregado reciclado conhecendo-se a natureza dos seus componentes.

Para determinar o tipo e a concentração dos materiais que compõem o agregado reciclado de Santo André, escolheu-se primeiramente uma das amostras acondicionadas em sacos plásticos com aproximadamente $11 \mathrm{~kg}$. Separou-se o material retido na peneira de $4,8 \mathrm{~mm}$ de abertura e através de uma análise visual, cada grão retido foi separado por classes de acordo com a sua natureza: cimentícia, rochosa, cerâmica ou resíduos indesejáveis. Foi utilizada apenas esta fração graúda, pois o passante possuía partículas muito pequenas, o que tornava difícil a sua distinção para uma classificação.

Os resultados são apresentados em forma de porcentagem, indicando a natureza e a concentração dos componentes do agregado reciclado estudado em laboratório, além de se conhecer qual é o material predominante.

\subsubsection{Materiais indesejáveis}

Os resíduos de construção e demolição pertencentes às classes $\mathrm{B}, \mathrm{C}$ e $\mathrm{D}$ da Resolução CONAMA no 307 (CONAMA, 2002) são denominados pela NBR 15115 
(ABNT, 2004) de materiais indesejáveis. Estes materiais indesejáveis são contaminantes do agregado reciclado, tais como: madeiras, vidros, plásticos, gessos, forros, tubulações, fiações elétricas, papéis e outros.

A porcentagem destes materiais indesejáveis deve ser investigada para a utilização do agregado reciclado em pavimentação. De acordo com a NBR 15115 (ABNT, 2004) e com a PMSP/SP ETS-001 (2003), a porcentagem máxima aceita de materiais indesejáveis de grupos distintos é de 3\%, e de mesma característica, limita-se em até $2 \%$ em massa.

Para verificar se o agregado reciclado de Santo André que foi trazido ao laboratório, atendia a esta recomendação da norma, selecionou-se uma amostra acondicionada em saco plástico, com aproximadamente $11 \mathrm{~kg}$. Esta amostra foi separada na peneira $4,8 \mathrm{~mm}$ e o material retido foi analisado visualmente, retirando-se por catação os indesejáveis encontrados.

O resultado obtido é apresentado em porcentagem de materiais indesejáveis em relação à massa total da amostra, ou seja, considerando-se também a parcela fina. Foi analisada também a natureza dos materiais indesejáveis que compõem o agregado reciclado estudado em laboratório.

\subsubsection{Determinação da massa específica dos grãos}

O processo de determinação da massa específica foi dividido em duas etapas, analisando-se primeiramente os grãos que passam na peneira de $4,8 \mathrm{~mm}$ e, em seguida, os retidos nesta malha.

\subsubsection{Grãos passantes na peneira $4,8 \mathrm{~mm}$}

A determinação da massa específica dos grãos de agregado reciclado que passam na peneira de 4,8mm foi realizada de acordo com a NBR 6508 (ABNT, 1984), norma utilizada para solos. Para a realização do ensaio separou-se a fração fina (menor que $4,8 \mathrm{~mm}$ ) de uma amostra acondicionada em saco plástico com aproximadamente $11 \mathrm{~kg}$ e tomaram-se duas partes, cada uma com pouco menos de $50 \mathrm{~g}$. 
Para o ensaio é necessário um picnômetro calibrado, ou seja, que se conheça o peso do picnômetro com água para diferentes temperaturas. Dessa forma, coloca-se uma quantidade conhecida de material no picnômetro, completa-o com água e determinase o seu peso total. Assim, é possível obter a massa específica dos grãos pela expressão (1):

$$
\delta=\frac{M_{1} \times 100 /(100+h)}{\left[M_{1} \times 100 /(100+h)\right]+M_{3}-M_{2}} \times \delta_{T}
$$

onde:

$\delta$ : massa especifica dos grãos, em $\left[\mathrm{g} / \mathrm{cm}^{3}\right]$;

$M_{1}$ : massa do solo úmido, em [g];

h: teor de umidade da amostra, em [\%];

$M_{2}$ : massa do picnômetro + solo + água na temperatura T de ensaio, em [g];

M3: massa do picnômetro cheio de água até a marca de referência na temperatura $T$ de ensaio, em [g];

$\delta_{T}$ : densidade da água na temperatura de ensaio, obtida na tabela anexada a NBR 6508 (ABNT, 1984).

De acordo com a NBR 6508 (ABNT, 1984), o ensaio com o picnômetro deve ser realizado para duas amostras e os resultados obtidos devem ser expressos em $\mathrm{g} / \mathrm{cm}^{3}$. A diferença da massa específica dos grãos obtida para as duas partes analisadas não pode ser maior que $0,02 \mathrm{~g} / \mathrm{cm}^{3}$.

\subsubsection{Grãos retidos na peneira $4,8 \mathrm{~mm}$}

Para a determinação da massa específica dos grãos retidos na peneira $4,8 \mathrm{~mm}$ baseouse na NBR 6458 (ABNT, 1984). Esta norma prescreve o método de ensaio para grãos de pedregulhos.

O ensaio foi preparado selecionando-se duas amostras de agregado reciclado acondicionadas em saco plástico. O material retido na peneira $4,8 \mathrm{~mm}$ foi separado e o passante descartado, obtendo-se cerca de $8 \mathrm{~kg}$ de agregados na fração graúda. Em 
seguida, por análise visual e catação, dividiu-se a amostra de acordo com a natureza dos seus materiais (cimentícia, rochosa, cerâmica ou resíduos indesejáveis). Cada grupo de material obtido foi lavado na peneira $4,8 \mathrm{~mm}$, de forma que as partículas finas aderidas aos grãos fossem retiradas. Depois da lavagem, colocou-se separadamente cada um dos grupos em imersão em água destilada por 24 horas.

A determinação da massa específica para uma fração graúda é feita através de uma pesagem hidrostática. Utilizou-se uma cesta metálica grande, acoplada a uma balança, e mediu-se separadamente a massa dos grãos imersos, para cada grupo de materiais obtido. Depois os materiais foram colocados na estufa a aproximadamente $100^{\circ} \mathrm{C}$ e, após total secagem, determinou-se a massa seca dos grãos de cada grupo. A massa específica dos grãos é dada pela seguinte expressão:

$\delta=\frac{M s}{M s-M i} \times \delta_{T}$

onde:

$\delta$ : massa especifica dos grãos, em $\left[\mathrm{g} / \mathrm{cm}^{3}\right]$;

Ms: massa seca dos grãos, em [g];

Mi: massa dos grãos imersos, em [g];

$\delta_{T}$ : densidade da água na temperatura de ensaio, obtida na tabela anexada a NBR 6458 (ABNT, 1984).

Após determinar a massa específica para cada grupo de material, a massa específica do conjunto foi calculada através de uma média ponderada. Como já havia sido analisada a composição do agregado reciclado estudado, conhecia-se a porcentagem presente de cada grupo. O resultado do ensaio é expresso em $\mathrm{g} / \mathrm{cm}^{3}$.

\subsubsection{Absorção}

A absorção indica a quantidade de água que um agregado é capaz de absorver e é uma das diferenças mais marcantes entre o agregado natural e o agregado reciclado (CARNEIRO et al., 2001). Muitas propriedades dos agregados podem ser influenciadas pela absorção de água. A alta capacidade de absorção, por exemplo, 
pode implicar em queda na resistência mecânica por enfraquecimento das ligações intergranulares (FRAZÃO, 2002).

De acordo com Vieira et al. (2004), os agregados reciclados, diferentemente dos naturais, têm uma alta taxa de absorção de água. Agregados reciclados com predominância de cimentícios apresentam capacidade de absorção menor que agregados reciclados com predominância de alvenaria, pela menor porosidade dos resíduos constituintes (LIMA, 1999).

Para a realização do ensaio de absorção dos grãos retidos na peneira $4,8 \mathrm{~mm}$ (pedregulho), utilizou-se a NBR 6458 (ABNT, 1984), que também é utilizada para a determinação da massa específica dos grãos da fração graúda. A determinação da absorção do agregado reciclado foi realizada com a divisão da amostra em diferentes grupos, de acordo com a natureza dos seus materiais constituintes (cimentícia, rochosa, cerâmica ou resíduos indesejáveis).

Cada grupo de material foi deixado imerso em água destilada por 24 horas. Após este tempo de imersão, foi removida a água destes agregados por uso de uma toalha ou pano levemente úmido; em seguida, os agregados foram pesados. Após este processo, os agregados foram levados à estufa, com temperatura aproximada de $100^{\circ} \mathrm{C}$, até a secagem dos mesmos e novamente pesados. $\mathrm{O}$ ensaio baseia-se na diferença entre o peso dos grãos "saturados" e o peso dos grãos secos, relacionado ao peso dos grãos secos, de acordo com a expressão (3):

$S=\frac{M_{h}-M_{s}}{M_{s}} \times 100$

onde:

S: absorção massa especifica dos grãos, em [\%];

$M_{h}$ : massa da amostra saturada, superficialmente seca, em [g];

$M_{s}$ : massa da amostra seca, em [g] 
A absorção foi obtida primeiramente para cada grupo de material e, em seguida, a absorção do conjunto foi calculada através de uma média ponderada. Este procedimento foi feito de forma análoga à determinação da massa específica média da fração retida na peneira $4,8 \mathrm{~mm}$. Como já havia sido analisada a composição do agregado reciclado estudado, conhecia-se a porcentagem presente de cada grupo. $\mathrm{O}$ resultado do ensaio é expresso em \%.

\subsubsection{Análise granulométrica}

Durante o desenvolvimento deste trabalho, várias análises granulométricas foram realizadas. Conduziram-se ensaios de granulometria para a caracterização física do agregado reciclado trazido ao laboratório e para verificar o seu estado de degradação após a compactação. Todos os ensaios foram executados de acordo com a NBR 7181 (ABNT, 1984), que é a norma utilizada para solos.

As análises granulométricas foram realizadas apenas por peneiramento, com lavagem na peneira $0,075 \mathrm{~mm}$. Para a realização dos ensaios, tomou-se sempre aleatoriamente uma amostra de Santo André acondicionada no saco plástico com aproximadamente $11 \mathrm{~kg}$. O material foi previamente lavado, para a remoção das partículas finas aderidas aos grãos, e em seguida seco em estufa, aproximadamente a $100^{\circ} \mathrm{C}$. A distribuição granulométrica do agregado reciclado foi determinada utilizando-se 13 peneiras: $50 ; 38 ; 25 ; 19 ; 9,5 ; 4,8 ; 2,0 ; 1,2 ; 0,6 ; 0,42 ; 0,25 ; 0,15$ e $0,075 \mathrm{~mm}$.

O resultado obtido com o ensaio de granulometria é normalmente expresso por meio da curva granulométrica. No eixo das abscissas estão em escala logarítmica as dimensões das partículas, ou as aberturas das peneiras, e no eixo das ordenadas estão as porcentagens passantes acumuladas em cada peneira analisada. De acordo com a forma da curva obtida é possível classificar granulometricamente o material em: uniforme, bem graduado ou mal graduado (DNIT, 2006). Esta classificação baseia-se no predomínio, ausência e/ou equilíbrio das frações grossas e finas por cálculo de índices que expressam a forma da curva. 
Normalmente são determinados os coeficientes de uniformidade $\left(\mathrm{C}_{\mathrm{u}}\right)$ e de curvatura $\left(\mathrm{C}_{\mathrm{c}}\right)$. A relação de $\mathrm{C}_{\mathrm{u}}$ representa a falta de uniformidade granulométrica, pois o seu valor diminui quando o material é mais uniforme. Valores baixos de $\mathrm{C}_{\mathrm{u}}$, menores que 15, indicam materiais de uniformidade média ou muito uniforme. Não é desejável que os agregados apresentem uniformidade, pois dessa forma o material é malgraduado, ocasionando muitos vazios e maiores quebras durante o processo de compactação ou pelo tráfego usuário após conclusão da obra. $\mathrm{O}$ coeficiente de curvatura $\mathrm{C}_{\mathrm{c}}$ deve se situar entre 1 e 3 para indicar que o material é bem-graduado. Estes coeficientes são calculados pelas expressões (4) e (5), respectivamente.

$$
\begin{aligned}
C_{u} & =\frac{d_{60}}{d_{10}} \\
C_{c} & =\frac{\left(d_{30}\right)^{2}}{d_{60} \times d_{10}}
\end{aligned}
$$

onde:

$C_{u}$ : coeficiente de uniformidade;

$C_{c}$ : coeficiente de curvatura;

$d_{10}$ : diâmetro correspondente a $10 \%$ da porcentagem passante, em [mm];

$d_{30}$ : diametro correspondente a $30 \%$ da porcentagem passante, em [mm];

$d_{60}$ : diâmetro correspondente a $60 \%$ da porcentagem passante, em [mm].

As normas existentes referentes ao uso do agregado reciclado em pavimentação não estabelecem uma faixa granulométrica para o emprego do mesmo. No entanto, são fixados alguns pontos que devem ser atendidos, como dimensão característica máxima dos grãos, porcentagem de material passante na peneira $0,42 \mathrm{~mm}, \mathrm{C}_{\mathrm{u}}$ e $\mathrm{C}_{\mathrm{c}} \cdot \mathrm{A}$ Tabela 4.1 apresenta os aspectos e os respectivos limites contemplados na normalização brasileira. 
Tabela 4.1: Aspectos e limites fixados pela norma e especificação brasileiras com relação à granulometria

\begin{tabular}{|c|c|c|c|c|}
\hline $\begin{array}{c}\text { Norma / } \\
\text { Especificação }\end{array}$ & $\begin{array}{c}\text { Dimensão } \\
\text { característica } \\
\text { máxima dos grãos } \\
{[\mathrm{mm}]}\end{array}$ & $\begin{array}{c}\text { Porcentagem que } \\
\text { passa na peneira } \\
0,42 \mathrm{~mm}[\%]\end{array}$ & $\mathrm{C}_{\mathrm{u}}$ & $\mathrm{C}_{\mathrm{c}}$ \\
\hline $\begin{array}{c}\text { NBR 15115 } \\
(\mathrm{ABNT}, 2004)\end{array}$ & 63,5 & $10 \leq \mathrm{a} \leq 40$ & $\geq 10$ & $\begin{array}{c}\text { não } \\
\text { consta }\end{array}$ \\
\hline $\begin{array}{c}\text { PMSP/SP } \\
\text { ETS-001 } \\
(\text { PMSP, 2003) }\end{array}$ & 50,0 & $10 \leq \mathrm{a} \leq 30$ & $\geq 10$ & $1 \leq \mathrm{a} \leq 3$ \\
\hline
\end{tabular}

Os resultados obtidos com o ensaio de granulometria são apresentados por meio de curvas granulométricas com porcentagens passantes e porcentagens acumuladas e tabelas com frações e porcentagens. Também foram calculados e analisados os coeficientes das curvas.

\subsubsection{Forma dos grãos}

Dependendo do tipo do resíduo de construção e demolição, e dos equipamentos utilizados durante o processo de reciclagem, o agregado reciclado pode apresentar forma mais lamelar e textura mais áspera que os agregados convencionais (LIMA, 1999).

A determinação da forma foi feita de acordo com a norma NBR 6954 (ABNT, 1989). Esta norma prescreve o método de determinação da forma para o material lastropadrão utilizado em via férrea. A análise da forma é feita com um paquímetro, medindo-se comprimento (a), largura (b) e altura (c) de cada grão, classificando o material como cúbico, alongado, lamelar e alongado-lamelar. A Tabela 4.2 apresenta a relação e classificação da forma dos grãos. 
Tabela 4.2: Classificação da forma dos grãos conforme NBR 6954 (ABNT, 1989)

\begin{tabular}{|l|c|}
\hline \multicolumn{1}{|c|}{ Média das relações b/a e c/b } & Classificação da forma \\
\hline b/a maior que 0,5 e c/b maior que 0,5 & cúbico \\
\hline b/a menor que 0,5 e c/b maior que 0,5 & alongado \\
\hline b/a maior que 0,5 e c/b menor que 0,5 & lamelar \\
\hline b/a menor que 0,5 e c/b menor que 0,5 & alongado-lamelar \\
\hline
\end{tabular}

A NBR 15115 (ABNT, 2004) a PMSP/SP ETS-001 (PMSP, 2003) recomendam que o agregado reciclado tenha no máximo $30 \%$ de grãos lamelares.

Para a realização do ensaio, selecionou-se uma amostra acondicionada em saco plástico com aproximadamente $11 \mathrm{~kg}$ e separaram-se quatro frações retidas do material: 38, 25, 19 e 9,5mm. Em seguida estas frações foram separadas de acordo com sua natureza, para verificar se um determinado tipo de material possuía tendência de apresentar uma determinada forma. As medições de comprimento, largura e altura dos grãos neste trabalho foram feitas com um paquímetro digital. As Figura 4.7 e Figura 4.8 ilustram o ensaio e exemplos de partículas pertencentes a cada uma das quatro frações retidas analisadas.

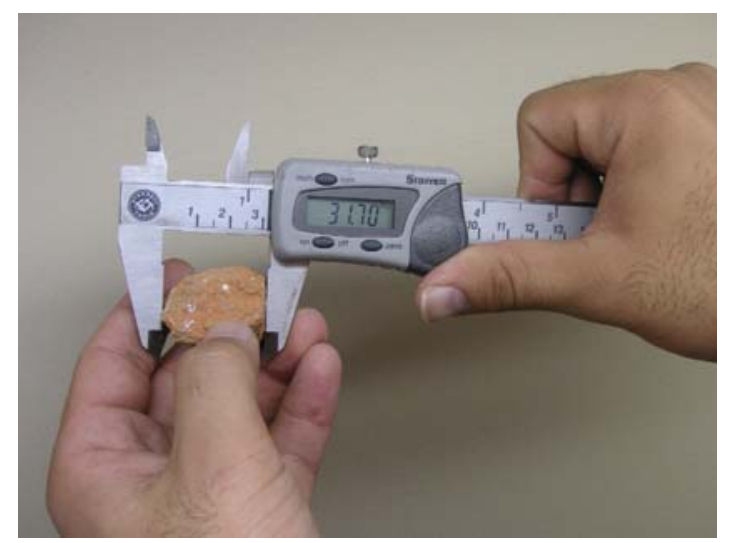

Figura 4.7: Medição com paquímetro digital

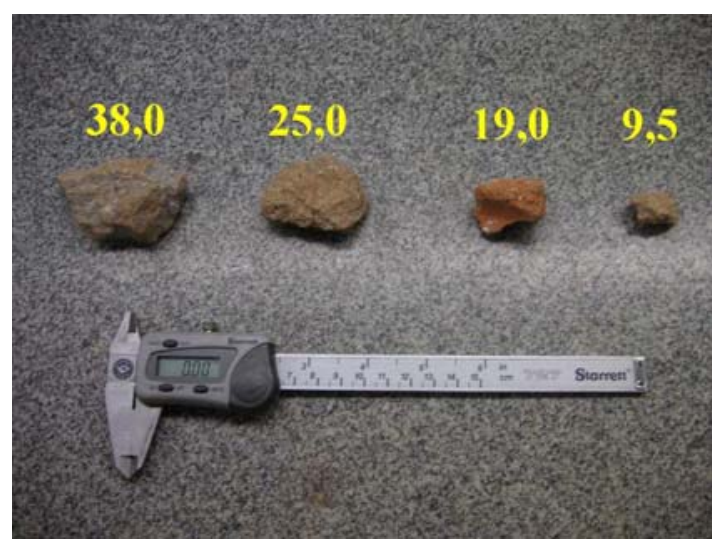

Figura 4.8: Exemplos de partículas pertencentes às frações analisadas

Os resultados são apresentados em porcentagem de partículas cúbicas, alongadas, lamelares e alongadas-lamelares, além de verificar a concentração destas formas de acordo com a natureza dos materiais. 


\subsection{Ensaios de compactação}

A compactação de um material para ser utilizado como camada constituinte de um pavimento permite aumentar a sua densificação e assim reduzir o índice de vazios. Este processo implica na melhoria de diversas propriedades, como aumento da resistência ao cisalhamento e diminuição da deformabilidade. Além disso, o aumento do contato entre os grãos torna o conjunto mais estável (DNIT, 2006; PINTO, 2000).

O ensaio de compactação pode ser realizado utilizando-se diferentes energias: normal, intermediária e modificada. Quanto maior a energia de compactação empregada, menor será o valor do teor de umidade ótima, e maior será o valor do peso específico aparente seco máximo. A escolha da energia é feita em função do uso que será dado ao material analisado.

Neste trabalho, foram realizados dois ensaios de compactação com o agregado reciclado de Santo André. A umidade ótima foi determinada para as energias intermediária e modificada.

Para a realização de ensaios de módulo de resiliência e deformação permanente foram compactados corpos-de-prova de $150 \mathrm{~mm}$ de diâmetro por $300 \mathrm{~mm}$ de altura. Foram analisadas ainda as modificações na granulometria e na forma dos grãos do agregado reciclado após a compactação.

\subsubsection{Determinação da umidade ótima e peso específico aparente seco máximo}

O agregado reciclado analisado em laboratório foi submetido ao ensaio de compactação conforme prescreve a NBR 7182 (ABNT, 1986), utilizada normalmente para solos. Como a NBR 15115 (ABNT, 2004) recomenda que para emprego em camadas de base o agregado reciclado seja compactado no mínimo na energia intermediária, foram realizados em laboratório ensaios de compactação empregandose a energia intermediária e a energia modificada. Além disso, o projeto do pavimento da USP Leste estipulava que o agregado reciclado fosse compactado com no mínimo $95 \%$ na energia modificada. 
Os ensaios foram realizados utilizando-se o soquete grande com aproximadamente $4,5 \mathrm{~kg}$ e o cilindro metálico grande (cilindro de CBR - California Bearing Ratio) com disco espaçador (Figura 4.9 e Figura 4.10). Este molde produz corpos de prova de $150 \mathrm{~mm}$ de diâmetro por $125 \mathrm{~mm}$ de altura. Para a execução do experimento, o cilindro foi preenchido com o agregado reciclado em cinco camadas. No ensaio com energia intermediária foram utilizados 26 golpes por camada e com energia modificada, 55 golpes por camada.

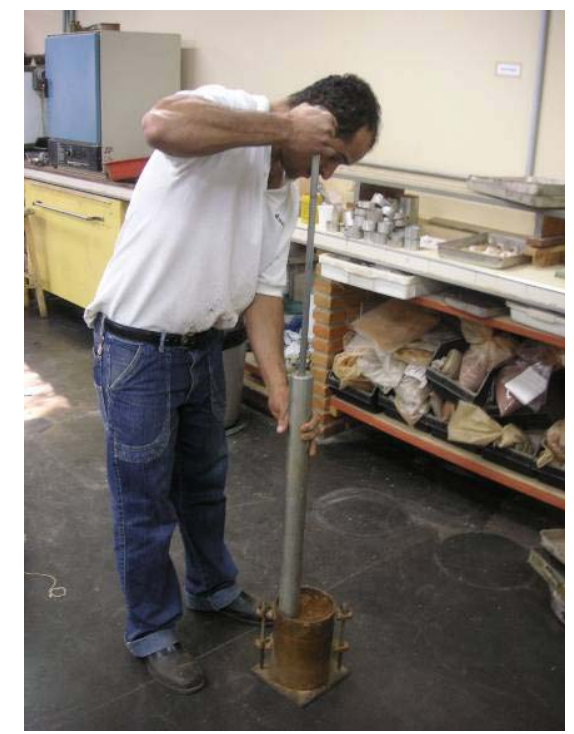

Figura 4.9: Soquete grande e cilindro metálico grande

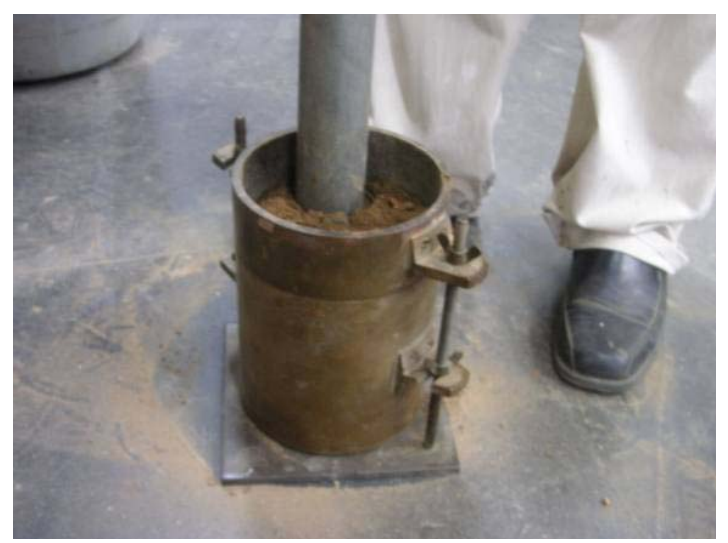

Figura 4.10: Detalhe do cilindro e compactação

Para a realização de cada ensaio de compactação foram moldados cinco corpos-deprova, sem reuso do material. A NBR 7182 (ABNT, 1986) indica que a curva de compactação deve ser obtida com cinco pontos, sendo dois no ramo seco, um próximo à umidade ótima e dois no ramo úmido da curva.

No caso do material de Santo André aqui estudado a quantidade de material retido na peneira $19 \mathrm{~mm}$ ficou entre $10 \%$ e $30 \%$. Desse modo, de acordo com a NBR 6457 (ABNT, 1986), que indica os procedimentos para ensaios de compactação, foi necessário substituir o material retido na peneira $19 \mathrm{~mm}$ por igual quantidade em peso de material passante na peneira $19 \mathrm{~mm}$ e retido na peneira $4,8 \mathrm{~mm}$. Para isto foram selecionadas e peneiradas várias amostras de agregado reciclado acondicionadas em sacos plásticos, obtendo-se assim estas frações desejadas. Cada corpo-de-prova 
moldado para o ensaio de compactação teve sua granulometria composta com substituição de material.

O resultado deste ensaio é expresso através das curvas de compactação, que possuem formato de sino, tendo no eixo das abscissas os teores de umidade utilizados e no eixo das ordenadas os respectivos valores de pesos específicos aparentes secos obtidos. Apresentam-se curvas de diferentes graus de saturação do agregado reciclado de Santo André juntamente com as curvas de compactação. No caso de saturação igual a 100\%, o volume de vazios do material seria igual ao volume de água. O grau de saturação é determinado pela expressão (6):

$$
\gamma_{s}=\frac{S}{\frac{h}{\delta_{a}}+\frac{S}{\delta}}
$$

onde:

$\gamma_{s}:$ massa especifica aparente seca, em $\left[\mathrm{g} / \mathrm{cm}^{3}\right]$;

S: grau de saturação, em [\%];

h: teor de umidade, arbitrado na faixa de interesse, em [\%];

$\delta_{a}$ : massa especifica da água, em $\left[\mathrm{g} / \mathrm{cm}^{3}\right]$;

$\delta$ : massa especifica dos grãos, em $\left[\mathrm{g} / \mathrm{cm}^{3}\right]$.

A massa específica dos grãos utilizada nos cálculos foi uma média ponderada das massas específicas entre a fração retida e passante na peneira $4,8 \mathrm{~mm}$, conforme apresentado no item 4.2.3.

\subsubsection{Compactação de corpos-de-prova de $150 \mathrm{~mm}$ x $300 \mathrm{~mm}$}

Para a realização dos ensaios de módulo de resiliência e de deformação permanente com o agregado reciclado de Santo André, foram utilizados corpos-de-prova cilíndricos, com diâmetro de $150 \mathrm{~mm}$ e altura de $300 \mathrm{~mm}$. A moldagem destes corposde-prova não exigiu a substituição da fração retida na peneira $19 \mathrm{~mm}$, utilizando-se o material na sua forma integral. 
A moldagem de corpos-de-prova em cilindros de $150 \mathrm{~mm}$ por $300 \mathrm{~mm}$ para ensaio de módulo de resiliência e deformação permanente também foi adotada por Bennert et al. (2000), Arm (2001), Hill et al. (2001) e Motta (2005).

A compactação foi feita com o soquete grande, de $4,5 \mathrm{~kg}$, e um molde metálico tripartido (Figura 4.11 e Figura 4.12). Os corpos-de-prova de agregado reciclado foram moldados em seis camadas nas energias intermediária e modificada, utilizando-se respectivamente 57 e 115 golpes por camada, conforme obtido pelo cálculo da energia.

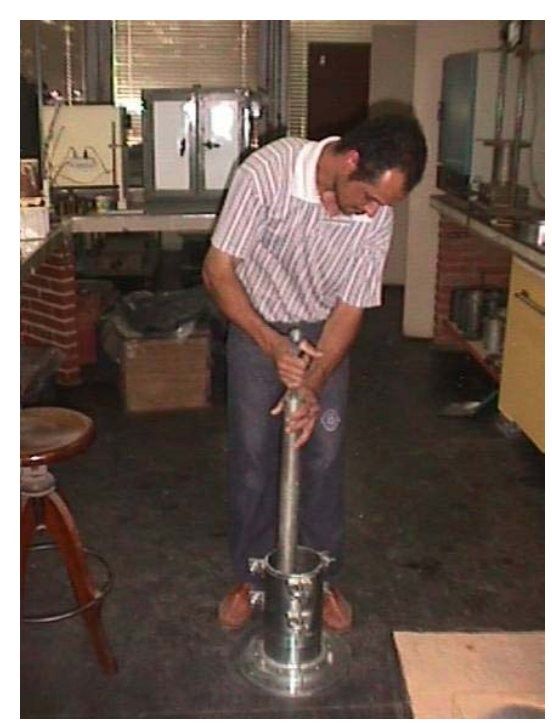

Figura 4.11: Compactação no cilindro $150 \mathrm{~mm} \times 300 \mathrm{~mm}$

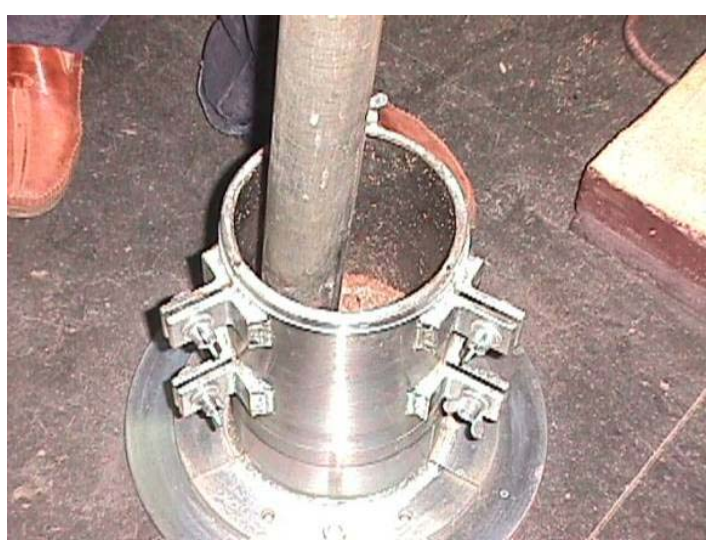

Figura 4.12: Detalhe do cilindro tripartido

O material utilizado em cada corpo-de-prova teve sua granulometria controlada, de forma que fosse possível garantir a curva granulométrica inicial do agregado reciclado. Para isto, separaram-se várias amostras acondicionadas em sacos plásticos e, por peneiramento, dividiu-se o material em cinco frações. Em seguida, fez-se uma composição granulométrica, de acordo com a curva granulométrica inicial obtida na caracterização do agregado reciclado de Santo André em laboratório.

$\mathrm{Na}$ moldagem de corpos-de-prova na energia intermediária e modificada, foram utilizados os respectivos teores de umidade ótima obtidos com o ensaio de 
compactação nos cilindros de CBR, com substituição da parcela de agregado reciclado retida da peneira $19 \mathrm{~mm}$.

Antes de submeter os corpos-de-prova de $150 \mathrm{~mm}$ x $300 \mathrm{~mm}$ aos ensaios, estes foram deixados em câmara úmida por quatro dias. Este período foi aplicado baseando-se nas especificações européias para a realização de ensaios triaxiais em materiais granulares, que recomenda uma "cura" de quatro a sete dias, para melhor distribuição da umidade. Além disso, segundo Molenaar e van Niekerk (2002), o agregado reciclado apresenta intrinsecamente e potencialmente grande quantidade de materiais cimentantes, que podem implicar no aumento da resistência, da rigidez e da resistência à deformação permanente com o tempo.

\subsubsection{Análise da influência da compactação}

Durante a moldagem dos corpos-de-prova em laboratório, verificou-se que a aplicação de grandes quantidades de energia de compactação implicava na quebra de partículas do agregado reciclado. Desse modo, decidiu-se estudar as modificações na granulometria e na forma do material.

\subsubsection{Granulometria}

Para a utilização de agregados reciclados em pavimentação, a NBR 15115 (ABNT, 2004) e a PMSP/SP ETS-001 (PMSP, 2003) recomendam alguns aspectos em relação à granulometria do material. De acordo com Valle (1994) é importante conhecer o potencial de degradação de agregados, para que se possa avaliar o comportamento do pavimento e interpretar seu funcionamento estrutural.

Para análise da modificação granulométrica, foram utilizados corpos-de-prova cilíndricos, com $150 \mathrm{~mm}$ de diâmetro e $300 \mathrm{~mm}$ de altura. Primeiramente foram separadas várias amostras de agregado reciclado de Santo André acondicionadas em sacos plásticos e, por peneiramento, dividiu-se o material em cinco frações. A granulometria foi composta de acordo com a curva original do material, obtida na etapa de caracterização. 
Foram compactados dois corpos-de-prova, nas energias intermediária e modificada, com os respectivos teores de umidade ótima obtidos previamente. Após a moldagem, estes corpos-de-prova foram destorroados com a mão com leves esforços e secos ao ar, até atingir a umidade higroscópica. Em seguida, o material foi lavado na peneira $0,075 \mathrm{~mm}$ e levado à estufa para secagem, com temperatura aproximada de $100^{\circ} \mathrm{C}$.

Após seco, o material foi submetido a peneiramento, de acordo com a NBR 7181 (ABNT, 1984) utilizando-se as mesmas 13 peneiras do ensaio de granulometria na etapa de caracterização. Foram obtidas desta forma duas curvas granulométricas, uma para o corpo-de-prova compactado na energia intermediária e outra para o corpo-de-prova compactado na energia modificada.

Para avaliar as alterações ocorridas na curva granulométrica, foram verificados os aspectos contemplados pela NBR 15115 (ABNT, 2004) e pela a PMSP/SP ETS-001 (PMSP, 2003) quanto à dimensão máxima característica dos grãos, porcentagem passante na peneira $0,42 \mathrm{~mm}, \mathrm{C}_{\mathrm{u}}$ e $\mathrm{C}_{\mathrm{c}}$.

Complementando a análise, foi calculado o índice de degradação de Ruiz após a compactação para os materiais ensaiados. A energia do ensaio de compactação produz uma variação na distribuição granulométrica do material, caracterizada por um deslocamento $\Delta \mathrm{i}$ em cada peneira. $\mathrm{O}$ índice de degradação de Ruiz é obtido a partir do somatório dos deslocamentos $\Delta \mathrm{i}$ da curva granulométrica em cada peneira, dividido pelo número de peneiras usadas no ensaio (VALLE, 1994 apud BUZATTI, $1987^{2}$ ). Este índice é obtido pela expressão (7):

$$
I D=\frac{\sum \Delta i}{n}
$$

onde:

ID: indice de degradação de Ruiz;

\footnotetext{
${ }^{2}$ BUZATTI, D. J. Índice de abrasão Los Angeles e índice de degradação: análise comparativa para diversas naturezas de agregados. Departamento de Estradas de Rodagem do Estado de Minas Gerais, Publicação Técnica nº. 23, 1987.
} 
n: número de peneiras utilizadas no ensaio;

$\Delta i$ : deslocamentos da curva granulométrica.

Assim, um valor de ID igual a zero define um agregado ideal, resistente a degradação. O valor máximo de ID será 100, definindo um agregado de péssima qualidade (VALLE, 1994 apud BUZATTI, 1987).

\subsubsection{Forma}

Foram analisadas as alterações na forma provocadas pela compactação nas energias intermediária e modificada. Para isto aproveitaram-se os dois corpos-de-prova moldados para o estudo das modificações granulométricas. Depois do peneiramento, separaram-se de cada uma das duas amostras as quatro frações utilizadas para verificar a forma dos grãos: $38,25,19$ e $9,5 \mathrm{~mm}$.

A determinação da forma foi feita de acordo com a norma NBR 6954 (ABNT, 1989), já apresentada no item 4.2.6. Com um paquímetro digital determinaram-se comprimento, largura e altura de cada grão, classificando o material como cúbico, alongado, lamelar ou alongado-lamelar. Os resultados são apresentados em porcentagem de partículas cúbicas, alongadas, lamelares e alongadas-lamelares para cada energia, comparando-se com os valores obtidos para o material inicial, antes da compactação.

\subsection{Ensaios mecânicos}

Esta etapa consistiu na realização de três ensaios com o agregado reciclado de Santo André aqui estudado: (i) índice de suporte Califórnia, (ii) módulo de resiliência e (iii) deformação permanente.

Com o objetivo de verificar o efeito da intensidade de compactação nas propriedades mecânicas, foram utilizados nos ensaios corpos-de-prova compactados nas energias intermediária e modificada. De acordo com Molenaar e van Niekerk (2002), o grau de compactação tem uma grande influência na rigidez e na resistência à deformação permanente do agregado reciclado. 


\subsection{1 Índice de suporte Califórnia}

O índice de suporte Califórnia (ISC), em inglês California Bearing Ratio (CBR), é bastante difundido no meio rodoviário. Através deste índice, expresso em porcentagem, é possível fazer o dimensionamento de pavimentos por métodos empíricos.

O ISC define o valor da capacidade de suporte de solos e materiais granulares empregados em pavimentação. $\mathrm{O}$ ensaio consiste na determinação da relação entre a pressão necessária para produzir uma penetração de um pistão em um corpo-deprova de solo, e a pressão necessária para produzir a mesma penetração num material granular padrão de referência (DNIT, 2006).

A NBR 15115 (ABNT, 2004) e a PMSP/SP ETS-001 (PMSP, 2003) utilizam o valor do ISC como parâmetro para emprego do agregado reciclado em pavimentação. São fixados valores mínimos de acordo com a função estrutural do material no pavimento: base, sub-base ou reforço de subleito. Além disso, considera-se também a expansão do agregado reciclado. A Tabela 4.3 apresenta os valores mínimos e máximos recomendados.

Tabela 4.3: Valores mínimos de ISC e máximos de expansão recomendados para emprego de agregado reciclado em camadas de pavimentos

\begin{tabular}{|c|c|c|c|c|}
\hline $\begin{array}{c}\text { Norma / } \\
\text { Especificação }\end{array}$ & Parâmetro & Base & Sub-base & $\begin{array}{c}\text { Reforço de } \\
\text { subleito }\end{array}$ \\
\hline NBR 15115 & ISC [\%] & $\geq 60^{\text {(c) }}$ & $\geq 20$ & $\geq 12$ \\
\cline { 2 - 5 }$($ ABNT, 2004) & Expansão [\%] & $\leq 0,5$ & $\leq 1,0$ & $\leq 1,0$ \\
\hline $\begin{array}{c}\text { PMSP/SP } \\
\text { ETS-001 } \\
(\text { PMSP, 2003) }\end{array}$ & ISC [\%] & $\geq 60^{(\mathrm{d})}$ & $\geq 20$ & $\geq 12$ \\
\cline { 2 - 5 } & Expansão [\%] & $\leq 0,5$ & $\leq 1,0$ & $\leq 1,0$ \\
\hline
\end{tabular}

(c) É permitido o uso de agregado reciclado em camada de base para vias de tráfego com $\mathrm{N} \leq 10^{6}$ repetições do eixo-padrão de $80 \mathrm{kN}$ no período do projeto.

(d) É permitido o uso de agregado reciclado em camada de base para vias de tráfego com $\mathrm{N} \leq 10^{5}$ repetições do eixo-padrão de $80 \mathrm{kN}$ no período do projeto. 
Neste trabalho, para a determinação do ISC do agregado reciclado de Santo André foram conduzidos ensaios conforme o método DNER-ME 049/94 (DNER, 1994), utilizado para solos. Os corpos-de-prova foram moldados no cilindro metálico de CBR, empregando-se apenas o material passante na peneira 19,0mm. Foi necessário substituir material como apresentado no item 4.3.1.

Foram compactados, nas respectivas umidades ótimas, quatro corpos-de-prova na energia intermediária e quatro na energia modificada. Depois de compactados, cada corpo-de-prova recebeu uma sobrecarga de discos anulares de aproximadamente $4,5 \mathrm{~kg}$ e foram levados à imersão em água por quatro dias (Figura 4.13). Este procedimento é utilizado para verificar a expansão do material e para simular durante o ensaio de penetração uma condição desfavorável em campo.

A expansão axial foi medida por extensômetros montados em tripés colocados sobre cada corpo-de-prova. A cada 24 horas durante o período de imersão foram feitas leituras, observando-se assim as variações de altura dos corpos-de-prova.

Após os quatro dias de imersão, os corpos-de-prova foram submetidos a uma prensa com um pistão de aproximadamente $50 \mathrm{~mm}$ de diâmetro, a uma velocidade de penetração de 1,27 milímetros por minuto. Controlou-se a deformação por meio de um extensômetro fixo no pistão e apoiado no cilindro metálico (Figura 4.14). As cargas de reação foram registradas por meio de um anel dinamométrico acoplado à prensa. As leituras das cargas foram feitas de acordo com os tempos estabelecidos no método DNER-ME 049/94 (DNER, 1994). 


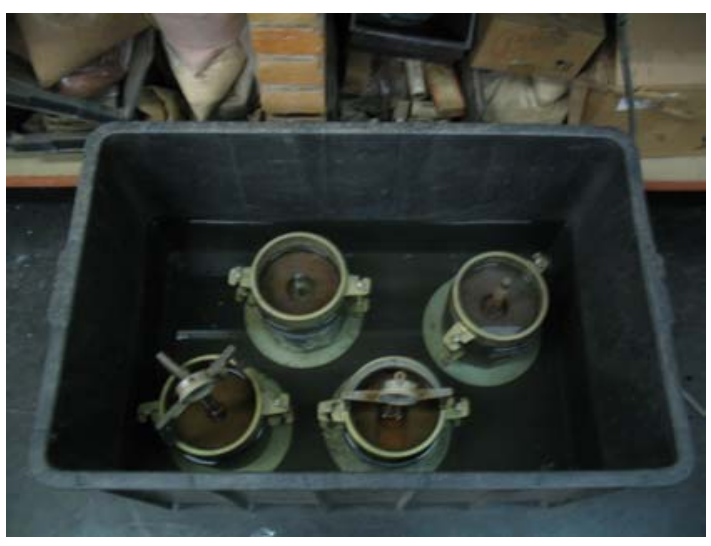

Figura 4.13: Corpos-de-prova em imersão para determinar expansão

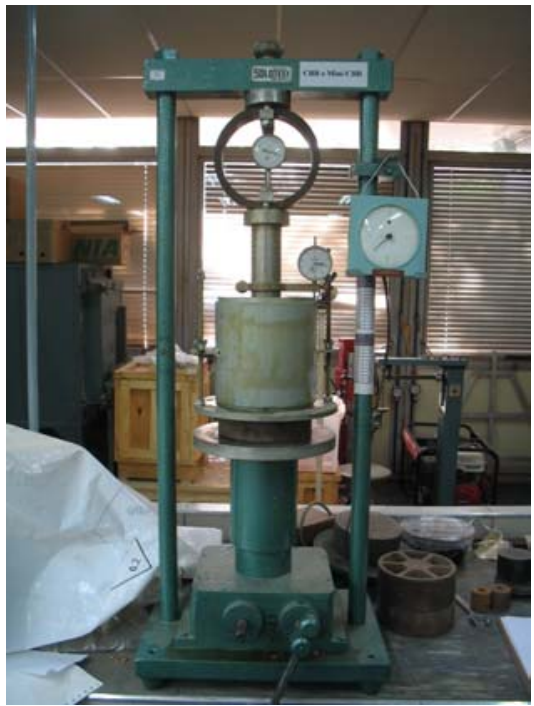

Figura 4.14: Corpo-de-prova submetido à prensa

O ISC é obtido através de uma curva onde no eixo das abscissas está a penetração e no eixo das ordenadas a respectiva pressão. Caso exista um ponto de inflexão, a curva deve ser corrigida com uma tangente até o eixo das abscissas. O valor de penetração neste ponto deve ser utilizado para a correção das medidas correspondentes às penetrações de 0,1 e 0,2 polegadas.

Assim, as pressões correspondentes às penetrações de 0,1 e 0,2 polegadas devem ser expressas em porcentagem em relação às pressões padrões da brita padronizada, apresentadas no método de ensaio. O ISC empregado é o maior valor obtido em porcentagem para estas duas leituras.

Os resultados de ISC e expansão são apresentados em forma gráfica, comparando os valores obtidos dos corpos-de-prova compactados na energia intermediária com os compactados na modificada. Também foi verificado se os ISC estão de acordo com a NBR 15115 (ABNT, 2004) e com a PMSP/SP ETS-001 (PMSP, 2003) para emprego em camadas de base e sub-base.

\subsubsection{Módulo de resiliência}

A maioria dos materiais de pavimentação não apresenta comportamento elástico, sofrendo alguma deformação permanente após cada aplicação do carregamento. 
Contudo, se o carregamento é pequeno comparado com a resistência do material e se para um grande número de repetições as deformações para cada aplicação são quase totalmente recuperáveis, pode-se considerar o material elástico (HUANG, 2004).

A deformação recuperável do pavimento, quando este é submetido a carregamentos repetidos, é denominada deformação resiliente. No ano de 1946, Hveem desenvolveu o primeiro equipamento para medir o efeito da aplicação de cargas repetidas nos materiais. Em seguida, na década de 50, Seed e Fead desenvolveram um equipamento triaxial dinâmico, no qual os modelos atuais são baseados (BERNUCCI, 1995; MEDINA, 1997).

O tipo e a duração do carregamento utilizado em um ensaio de cargas repetidas devem simular o que ocorre no campo (HUANG, 2004).

O módulo de resiliência é obtido pela relação entre a tensão-desvio, denominada $\sigma_{\mathrm{d}}$, e a correspondente deformação axial resiliente, denominada $\varepsilon_{\mathrm{r}}$, sendo calculado através da expressão $(8)$. A tensão-desvio $\left(\sigma_{d}\right)$ equivale à tensão de confinamento $\left(\sigma_{3}\right)$ subtraída da tensão axial $\left(\sigma_{1}\right)$, aplicadas no corpo-de-prova, ou seja, é a diferença entre a tensão principal maior e a tensão principal menor.

$M_{R}=\frac{\sigma_{d}}{\varepsilon_{r}}$

onde:

$M_{R}$ : módulo de resiliência, em [MPa];

$\sigma_{d}$ : tensão-desvio, em [MPa];

$\varepsilon_{r}$ : deformação axial resiliente, em $[\mathrm{mm} / \mathrm{mm}]$.

Em função das cargas aplicadas serem normalmente pequenas, o ensaio de módulo de resiliência é do tipo não-destrutivo. Nesta pesquisa, o experimento foi realizado de forma semelhante ao especificado na norma do DNER-ME 131/94 (DNER, 1994) para solos. 
O equipamento utilizado para o ensaio foi o triaxial de carga repetida do Laboratório de Tecnologia de Pavimentação da Escola Politécnica da Universidade de São Paulo (LTP-EPUSP). A Figura 4.15 ilustra o equipamento empregado.

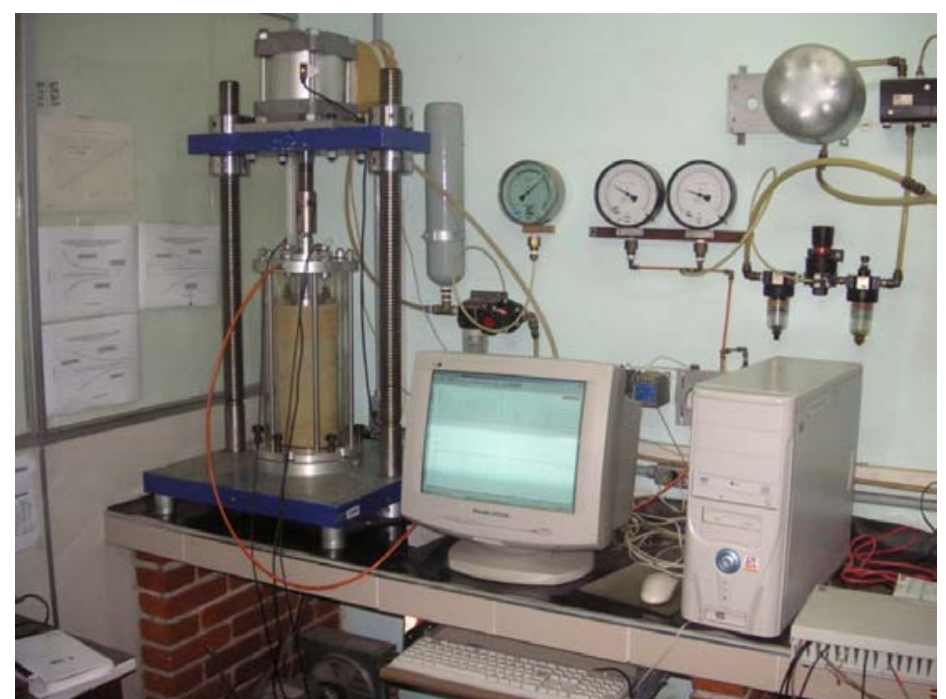

Figura 4.15: Equipamento triaxial de carga repetida do LTP-EPUSP

Para a determinação do módulo utilizou-se uma célula triaxial semelhante à maioria existente, no entanto com dimensões maiores, $200 \mathrm{~mm}$ de diâmetro e $400 \mathrm{~mm}$ de altura (Figura 4.16). O ensaio foi conduzido com corpos-de-prova de $150 \mathrm{~mm}$ de diâmetro e $300 \mathrm{~mm}$ de altura, conforme apresentado no item 4.3.2 deste trabalho (Figura 4.17).

Foram moldados em laboratório quatro corpos-de-prova com o agregado reciclado de Santo André: dois compactados na energia intermediária e dois na energia modificada. Todos os corpos-de-prova foram submetidos ao período de cura de quatro dias em câmara úmida, conforme justificado no item 4.3.2 deste trabalho.

Todos os corpos-de-prova foram envolvidos por uma membrana de borracha para a realização do ensaio triaxial de carga repetida. 


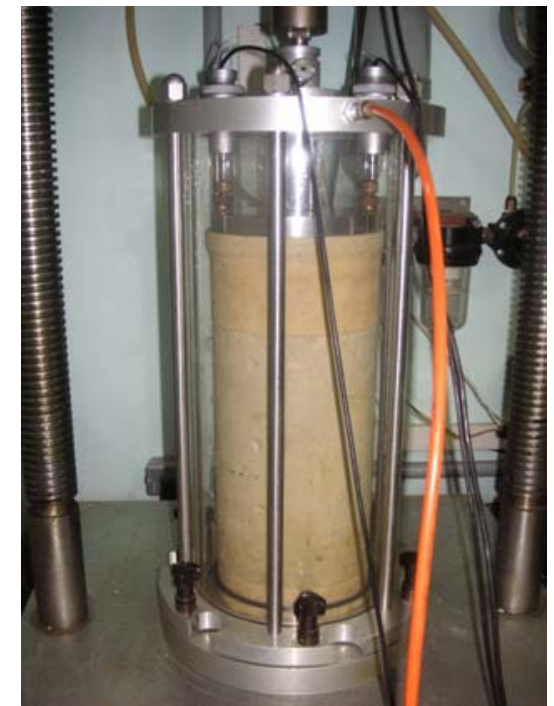

Figura 4.16: Célula triaxial grande utilizada no ensaio com carga repetida

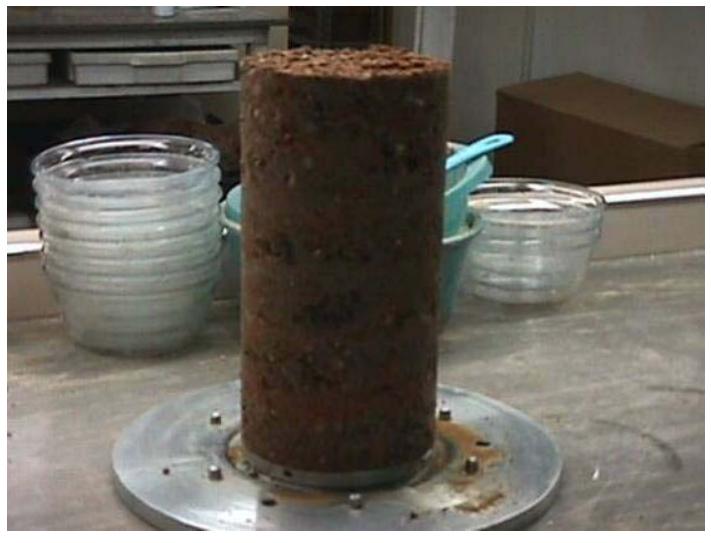

Figura 4.17: Corpo-de-prova de agregado reciclado com $150 \mathrm{~mm}$ x $300 \mathrm{~mm}$

O equipamento possui um sistema de ar comprimido com manômetros e válvulas que permite aplicar tensões $\sigma_{\mathrm{d}}$ e $\sigma_{3}$ conforme desejado. Neste trabalho, os corpos-deprova foram submetidos a diferentes tensões-desvio sempre com freqüência de $1 \mathrm{~Hz}$. Segundo Yoder e Witczak (1975) a freqüência de aplicação da carga produz pouco efeito no módulo de resiliência de materiais granulares.

A medição dos deslocamentos verticais no corpo-de-prova foi feita por transdutores do tipo LVDT (Linear Variable Differencial Transformer) posicionados no topo do corpo-de-prova. O sistema de medição dos deslocamentos é feito em relação a toda a altura do corpo-de-prova, com ajuste micrométrico externo à câmara triaxial.

O primeiro estágio do ensaio consiste no condicionamento do corpo-de-prova, onde são aplicadas duas tensões diferentes $\sigma_{3}$ e três tensões diferentes $\sigma_{\mathrm{d}}$, sem registro dos deslocamentos. Na seqüência, são aplicados conjuntos de três tensões $\sigma_{d}$ crescentes para cada tensão $\sigma_{3}$, registrando-se os deslocamentos resilientes. A Tabela 4.4 apresenta as tensões de confinamento e as tensões-desvio que foram utilizadas durante o ensaio. Cada tensão foi aplicada no mínimo 200 vezes antes da leitura do deslocamento resiliente. 
Tabela 4.4: Tensões aplicadas durante o ensaio de módulo de resiliência do agregado reciclado de Santo André

\begin{tabular}{|c|c|c|}
\hline Etapa do ensaio & $\sigma_{3}[\mathrm{kPa}]$ & $\sigma_{\mathrm{d}}[\mathrm{kPa}]$ \\
\hline \multirow{3}{*}{ Condicionamento } & 70 & 70 \\
\hline & 70 & 210 \\
\hline & 105 & 315 \\
\hline \multirow{18}{*}{$\begin{array}{c}\text { Registro } \\
\text { dos deslocamentos } \\
\text { resilientes }\end{array}$} & \multirow{3}{*}{21} & 21 \\
\hline & & 42 \\
\hline & & 63 \\
\hline & \multirow{3}{*}{35} & 35 \\
\hline & & 70 \\
\hline & & 105 \\
\hline & \multirow{3}{*}{52,5} & 52,5 \\
\hline & & 105 \\
\hline & & 157,5 \\
\hline & \multirow{3}{*}{70} & 70 \\
\hline & & 140 \\
\hline & & 210 \\
\hline & \multirow{3}{*}{105} & 105 \\
\hline & & 210 \\
\hline & & 315 \\
\hline & \multirow{3}{*}{140} & 140 \\
\hline & & 280 \\
\hline & & 420 \\
\hline
\end{tabular}

A partir dos deslocamentos resilientes coletados no ensaio e da expressão (8) é possível determinar os valores de módulo de resiliência para cada par de tensões $\sigma_{3} \mathrm{e}$ $\sigma_{\mathrm{d}}$ que foi imposto ao corpo-de-prova, e apresentá-los graficamente.

Experimentos realizados com materiais granulares para reforços de subleito, subbases e bases indicaram o grande efeito da tensão de confinamento nos resultados de módulo de resiliência (YODER e WITCZAK, 1975). Em função deste fato, normalmente para materiais granulares, o módulo de resiliência é apresentado pelas expressões (9) ou (10).

$M_{R}=k_{1} \sigma_{3}^{k_{2}}$

onde:

$M_{R}$ : módulo de resiliência, em [MPa]; 
$k_{1}, k_{2}$ : parâmetros do material obtidos com o ensaio;

$\sigma_{3}:$ tensão de confinamentos, em [MPa].

ou

$M_{R}=k_{1} \theta^{k_{2}}$

onde:

$M_{R}:$ módulo de resiliência, em [MPa];

$k_{1}$, $k_{2}$ : parâmetros do material obtidos com o ensaio;

O: soma das tensões principais, em [MPa].

onde:

$$
\theta=\sigma_{d}+3 \sigma_{3}
$$

Neste trabalho optou-se por utilizar a expressão (10), em função de $\theta$, plotando-se no eixo das ordenadas o módulo de resiliência e no eixo das abscissas a soma das tensões principais.

Os resultados obtidos com o ensaio de módulo de resiliência são apresentados em forma gráfica e em tabelas para determinados níveis de tensões, utilizando-se o modelo composto em função de $\theta$, representado pela expressão (10). A título comparativo, são apresentados os modelos obtidos utilizando-se a expressão (9), ou seja, em função de $\sigma_{3}$. Além disso, é feita uma comparação com módulos de resiliência de outras pesquisas com materiais semelhantes.

\subsubsection{Deformação permanente}

\subsubsection{Avaliação da deformação permanente}

A deformação permanente é um importante fator no projeto de pavimentos flexíveis. O dimensionamento deve garantir que ocorra nenhuma ou apenas pequena deformação permanente na estrutura. Estas deformações são observadas principalmente em trilhas de roda de caminhões e em áreas de estacionamentos com 
revestimentos asfálticos (WERKMEISTER et al., 2001; HUANG, 2004; MEDINA, 1997).

A experiência indica a grande importância de bases e sub-bases estáveis e resistentes na vida útil de um pavimento. Dessa forma, decidiu-se avaliar em laboratório a resistência à deformação permanente do agregado reciclado de Santo André aqui estudado.

Para determinar a deformação permanente de materiais granulares normalmente utilizam-se ensaios triaxiais com cargas repetidas. Estes ensaios são atualmente os mais empregados e aceitos na elaboração de modelos de previsão. Avaliam-se a relação entre o número de solicitações do carregamento e a deformação permanente acumulada, geralmente até atingir 100.000 ciclos (HUANG, 2004; BENNERT et al. 2000).

O ensaio para medir a deformação permanente é semelhante ao do módulo de resiliência. O mesmo equipamento triaxial de carga repetida do LTP-EPUSP foi utilizado (Figura 4.15), empregando-se corpos-de-prova de $150 \mathrm{~mm}$ de diâmetro e $300 \mathrm{~mm}$ de altura, conforme apresentado no item 4.3.2 deste trabalho.

Foram utilizados cinco corpos-de-prova para a determinação da deformação permanente do agregado reciclado de Santo André analisado em laboratório. Quatro corpos-de-prova foram compactados na energia modificada e um na energia intermediária. Todos os corpos-de-prova foram submetidos ao período de cura de quatro dias em câmara úmida e antes do ensaio foram envolvidos por uma membrana de borracha.

De acordo com a literatura revisada, diferentes níveis de tensão são empregados em ensaios de deformação permanente. Estes níveis devem tentar simular, se possível, o que ocorre no campo (HUANG, 2004). No entanto, não existe um critério definido para determinar qual relação entre a tensão-desvio e a tensão de confinamento deve 
ser aplicada. Neste trabalho, foram utilizados quatro níveis de tensões que são apresentados na Tabela 4.5 .

Tabela 4.5: Energia e níveis de tensões empregados nos ensaios de deformação permanente do agregado reciclado de Santo André

\begin{tabular}{|c|c|c|c|}
\hline \multirow{2}{*}{ Energia empregada } & $\sigma_{\mathrm{d}}[\mathrm{kPa}]$ & $\sigma_{3}[\mathrm{kPa}]$ & $\sigma_{\mathrm{d}} / \sigma_{3}$ \\
\hline Intermediária & 300 & 50 & $6,0^{(\mathrm{e})}$ \\
\hline \multirow{3}{*}{ Modificada } & 100 & 50 & 2,0 \\
\cline { 2 - 4 } & 200 & 50 & 4,0 \\
\cline { 2 - 4 } & 300 & 50 & $6,0^{(\mathrm{e})}$ \\
\cline { 2 - 4 } & 500 & 75 & 6,7 \\
\hline
\end{tabular}

(e) Nível de tensões observado logo abaixo do topo da camada de base, obtido por retroanálise da estrutura de projeto "seção-tipo 3".

A relação $\sigma_{d} / \sigma_{3}$ igual a 6,0 , apresentada em destaque, foi obtida por meio de retroanálise da estrutura de pavimento seção-tipo 3 apresentada no item 3.2 deste trabalho. Baseado em experiências anteriores e em literatura consultada, foram adotados para esta estrutura de projeto os módulos de resiliência apresentados na Tabela 4.6. Verificou-se que logo abaixo do topo da camada de base de agregado reciclado as tensões atuantes $\sigma_{\mathrm{d}}$ e $\sigma_{3}$ eram aproximadamente iguais a $300 \mathrm{kPa}$ e $50 \mathrm{kPa}$, respectivamente. Dessa forma, esta relação $\sigma_{\mathrm{d}} / \sigma_{3}$ igual a 6,0 procurou simular a previsão da deformação permanente no campo da base.

Tabela 4.6: Módulos de resiliência adotados na retroanálise da "seção-tipo 3"

\begin{tabular}{|l|c|c|c|}
\hline \multicolumn{1}{|c|}{ Camada } & Material & $\begin{array}{c}\text { Espessura } \\
{[\mathrm{mm}]}\end{array}$ & $\mathrm{M}_{\mathrm{R}}[\mathrm{MPa}]$ \\
\hline Revestimento & Concreto asfáltico & 100 & 3.000 \\
\hline Base & Agregado reciclado & 150 & 250 \\
\hline Sub-base & Agregado reciclado & 150 & 250 \\
\hline Reforço de subleito & Solo laterítico & 200 & 150 \\
\hline Subleito & Solo natural & semi-infinito & 75 \\
\hline
\end{tabular}

Estas tensões $\left(\sigma_{\mathrm{d}}=300 \mathrm{kPa}\right.$ e $\left.\sigma_{3}=50 \mathrm{kPa}\right)$ foram aplicadas para corpos-de-prova moldados nas energias intermediária e modificada. Teve-se como objetivo verificar a influência da compactação na resistência à deformação permanente do agregado reciclado de Santo André. 
Por meio do nível de tensão $\sigma_{\mathrm{d}} / \sigma_{3}$ igual a 6,7 procurou-se simular o caso de redução da espessura da camada de revestimento, aumentando-se $\sigma_{\mathrm{d}}$ e $\sigma_{3}$ para $500 \mathrm{kPa}$ e $75 \mathrm{kPa}$, respectivamente. Em função de limitações do equipamento triaxial de carga repetida de curta duração do LTP-EPUSP, não pôde ser aplicada uma tensão-desvio superior a $500 \mathrm{kPa}$.

Os níveis de tensões $\sigma_{\mathrm{d}} / \sigma_{3}$ igual a 2,0 e 4,0 procuraram demonstrar uma situação em que o tráfego fosse mais leve, já que existem limitações pela NBR 15115 (ABNT, 2004) e pela PMSP/SP ETS-001 (PMSP, 2003) sobre o uso de agregado reciclado em camadas de base. Além disso, teve-se como objetivo verificar o comportamento do agregado reciclado de Santo André submetido a um nível de tensões mais baixo.

Nas mesmas condições do ensaio com nível de tensões igual $\sigma_{d} / \sigma_{3}$ igual a 2,0 foi ensaiado um corpo-de-prova de brita graduada. A brita graduada utilizada possui a mesma granulometria do agregado reciclado de Santo André de laboratório após sua compactação na energia modificada. A compactação foi feita na energia modificada, utilizando o cilindro tripartido de $150 \mathrm{~mm}$ x $300 \mathrm{~mm}$ e umidade de $5,0 \%$. O objetivo deste ensaio com um material natural foi avaliar a diferença de seu comportamento em relação ao material reciclado.

Os ensaios para medir a deformação permanente são executados no mínimo até 100.000 ciclos. A deformação permanente acumulada é registrada em números determinados de repetições do carregamento. No entanto, podem ser realizadas leituras com mais freqüência. De acordo com Huang (2004), devem ser registradas as deformações permanentes nos seguintes ciclos: 1, 10, 100, 200, 1.000, $10.000 \mathrm{e}$ 100.0000 .

É extremamente difícil prever a vida útil de um material empregado no pavimento considerando a sua deformação permanente. Existem muitas variáveis nos métodos de ensaio e equipamentos, além das incertezas sobre as condições climáticas e de tráfego. No entanto, o uso de alguns modelos simplificados permite uma estimativa de ruptura (HUANG, 2004). 
De acordo com a literatura revisada, a maioria das pesquisas sobre deformação permanente emprega o modelo proposto por Monismith et al. (1975), que é apresentado no modelo (12):

$\varepsilon_{p}=a N^{b}$

onde:

$\varepsilon_{p}$ : deformação permanente, em $\left[10^{-3} \mathrm{~mm} / \mathrm{mm}\right]$;

a: deformação permanente após o primeiro ciclo, em $\left[10^{-3} \mathrm{~mm} / \mathrm{mm}\right]$;

N: número de ciclos;

b: inclinação da reta obtida por regressão.

Outro modelo muito encontrado na bibliografia é o de Barksdale ${ }^{3}$, citado por Bennert et al. (2000). A expressão (13) apresenta este modelo.

$\varepsilon_{p}=a+b \log N$

onde:

$\varepsilon_{p}$ : deformação permanente, em $\left[10^{-3} \mathrm{~mm} / \mathrm{mm}\right]$;

a: deformação permanente após o primeiro ciclo, em $\left[10^{-3} \mathrm{~mm} / \mathrm{mm}\right]$;

b: inclinação da reta obtida por regressão;

N: número de ciclos.

Utilizando os resultados obtidos nos ensaios até 100.000 ciclos, os modelos das equações (12) e (13) foram empregados para prever a deformação permanente do agregado reciclado de Santo André. Os valores obtidos com estas expressões foram comparados com os verificados experimentalmente. Além disso, são apresentados resultados obtidos em outras pesquisas desenvolvidas com agregados reciclados e com outros materiais.

\footnotetext{
${ }^{3}$ BARKSDALE, R. D. Repeated load test evaluation of base course materials. Georgia Highway Department Research Project 7002, Georgia Institute of Technology, Atlanta, 1972.
} 


\subsubsection{Teoria do shakedown}

A teoria do shakedown vem sendo muito utilizada para descrever o comportamento de estruturas de engenharia submetidas a carregamentos cíclicos. O principal objetivo desta teoria é verificar se a deformação permanente da estrutura pode conduzi-la à ruptura ou se tende à estabilização (GUIMARÃES, 2001).

A estabilização da deformação permanente depois de determinado número de ciclos, onde o material apresenta comportamento elástico, é denominada shakedown (SHARP e BOOKER, 1984).

De acordo com Werkmeister et al. (2001), pesquisas indicaram que para ensaios de cargas repetidas com baixos níveis de tensão $\left(\sigma_{\mathrm{d}} / \sigma_{3}\right)$ ocorre um estado de equilíbrio nas deformações permanentes após a estabilização do efeito pós-compactação. Contudo, para elevados níveis de tensão, a deformação permanente não se estabiliza e cresce rapidamente, podendo levar à ruptura.

Assim, existe a possibilidade de encontrar um estado de tensões crítico, caracterizado entre uma condição de deformação permanente estável e instável. Este nível de tensões é denominado "limite do shakedown".

A teoria do shakedown foi desenvolvida inicialmente para metais submetidos a cargas deslizantes ou rolantes. Esta teoria foi introduzida no estudo de pavimentos na Austrália em 1984 por Sharp e Booker. Um trecho experimental foi analisado por meio da teoria do skakedown, verificando-se a influência dos materiais e da geometria. O trabalho conclui que o shakedown em pavimentos pode ser observado e previsto, possibilitando que seja estimada a vida útil da estrutura submetida ao tráfego.

Pesquisas em laboratório para verificar a ocorrência de shakedown em materiais para pavimentos têm crescido muito nos últimos anos. Neste trabalho o estudo de 
shakedown foi baseado nos trabalhos de Werkmeistet et al. (2001) e Guimarães (2001).

Werkmeister et al. (2001) realizaram vários ensaios triaxiais de cargas repetidas para medir deformação permanente em materiais granulares. Foram aplicados diferentes níveis de tensões e tempos de carregamento. Concluíram que a representação gráfica dos resultados obtidos define três tipos de comportamento do material: limites A, B e C. O gráfico que caracteriza estas três respostas apresenta no eixo das abscissas a deformação permanente vertical acumulada e no eixo das ordenadas a razão entre a deformação permanente e o número de repetições acumuladas do carregamento. A Figura 4.18 apresenta o modelo de Werkmeister et al. (2001) apontando os limites. Os valores de $\sigma_{3}$ variam entre $70 \mathrm{kPa}$ e $280 \mathrm{kPa}$.

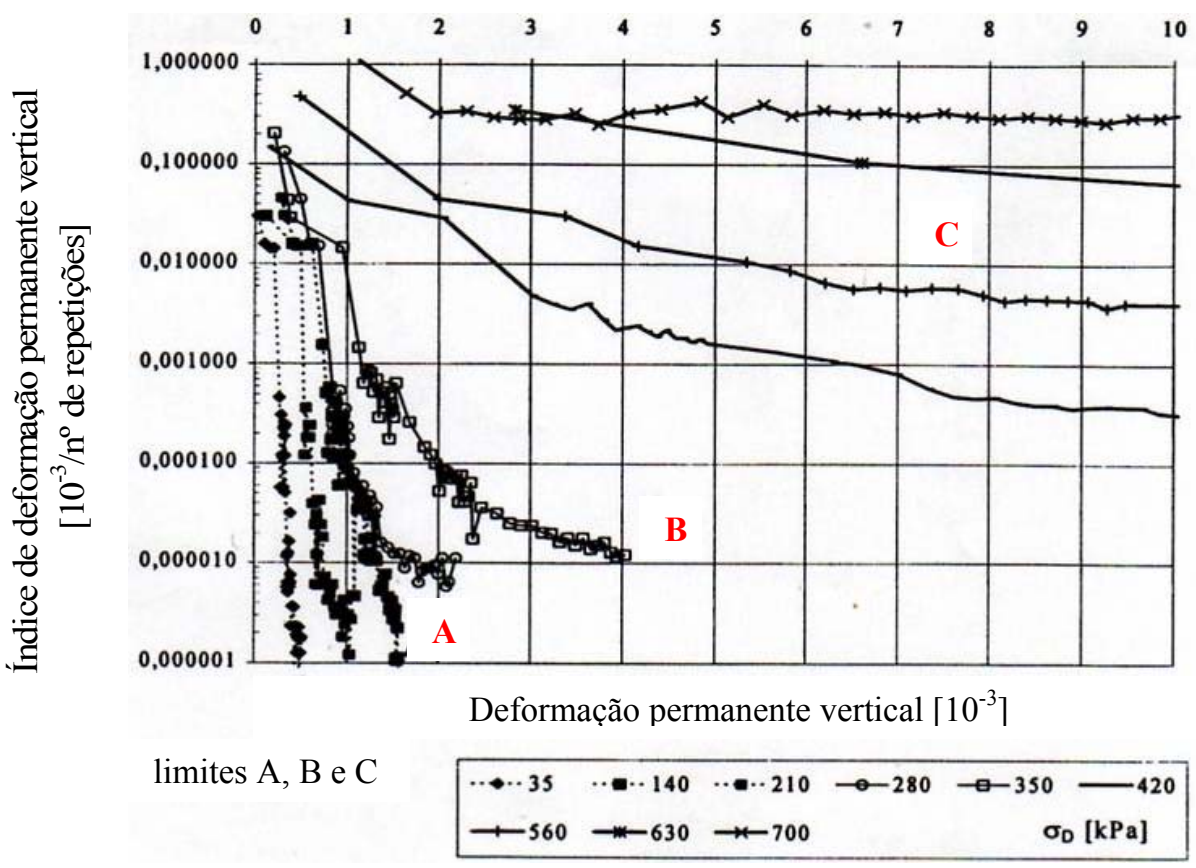

Figura 4.18: Deformação permanente para um material granular apresentando os limites A, B e C (WERKMEISTER et al., 2001)

Limite A - limite do shakedown plástico:

O material apresenta uma resposta plástica para um determinado número de ciclos, mas após o fim do período de pós-compactação existem apenas deformações resilientes. O comportamento passa a ser elástico, ou seja, sofre deformações recuperáveis. A resistência à deformação permanente nesta fase elástica depende do 
contato entre os grãos (material bem graduado = baixa deformação resiliente) e, provavelmente, não ocorrem quebras de partículas nesta fase.

\section{Limite $\mathrm{C}$ - colapso:}

O nível de tensões é muito elevado e o material sofre deformação permanente de forma rápida e intensa. A cada ciclo ocorrem deformações plásticas, sem cessar. A ruptura ocorre em curto prazo. Nesta fase provavelmente ocorre abrasão e quebra das partículas. Um pavimento bem dimensionado não deveria nunca atingir o limite $\mathrm{C}$.

\section{Limite B - resposta intermediária:}

O limite B corresponde a uma resposta intermediária entre os níveis A e C. Durante os primeiros ciclos de carregamento, a deformação permanente é elevada, mas decresce com as sucessivas aplicações de carga, até tornar-se constante. O número de ciclos para atingir esta deformação constante depende do material e do nível de tensões aplicado. A resistência à deformação permanente depende das características físicas dos grãos como a sua forma, por exemplo, e do contato entre as partículas.

Guimarães (2001) verificou a teoria do shakedown para uma argila laterítica e para uma laterita, para diferentes níveis de tensões. Na pesquisa foi possível distinguir o comportamento shakedown em alguns corpos-de-prova de laterita.

Neste trabalho, analisou-se à luz da teoria do shakedown, o agregado reciclado de Santo André durante o ensaio de deformação permanente. Foi utilizado o equipamento triaxial de carga repetida do LTP-EPUSP (Figura 4.15).

Foram empregados os cinco corpos-de-prova de agregado reciclado do ensaio de deformação permanente, com $150 \mathrm{~mm}$ de diâmetro e $300 \mathrm{~mm}$ de altura: quatro corposde-prova compactados na energia modificada e um na energia intermediária. Todos os corpos-de-prova foram submetidos ao período de cura de quatro dias em câmara úmida e antes do ensaio foram envolvidos por uma membrana de borracha.

Os estados de tensões aplicados foram os mesmos apresentados na Tabela 4.5. 
Os ensaios com carregamento cíclico para medir a deformação permanente são normalmente levados até a 100.000 repetições. Para verificar os limites A ou B do shakedown não existe um número determinado, mas geralmente é necessário um número de aplicações maior ainda aos 100.000. Foram encontrados na bibliografia ensaios com 100.000 até 1.000 .000 de ciclos. Neste trabalho optou-se por conduzir os ensaios até 180.000 repetições.

Assim, no item 4.4.3, que trata da deformação permanente, analisou-se o comportamento do agregado reciclado até o 100.000 ciclos do ensaio. Já neste item 4.4.4 verificou-se a resposta do material, quanto à teoria do shakedown, até o 180.000 ciclos.

Os resultados obtidos nos ensaios até 180.000 ciclos são apresentados em forma gráfica, apresentando no eixo das abscissas a deformação permanente vertical acumulada e no eixo das ordenadas a razão entre a deformação permanente e o número de ciclos.

\subsection{Controle tecnológico em campo}

Por meio do controle tecnológico realizado nas obras de pavimentação, espera-se monitorar direta ou indiretamente três propriedades geotécnicas:

- Resistência: deve ser suficiente de acordo com a solicitação prevista;

- Deformabilidade: precisa ser controlada com o objetivo de evitar ou reduzir as deformações e limitar as tensões atuantes, para evitar fadiga precoce de camadas cimentadas e asfálticas;

- Permeabilidade: necessária para manter a estabilidade da estrutura submetida a infiltrações e flutuações do nível do lençol freático.

A fiscalização da obra de pavimentação do campus da USP Leste foi realizada pela empresa Concremat Engenharia e Tecnologia S.A., que cedeu gentilmente os relatórios de acompanhamento. Neste trabalho são apresentados em detalhes apenas os resultados do controle tecnológico referentes ao agregado reciclado. 
O controle tecnológico empregado foi baseado na NBR 15115 (ABNT, 2004), dividido em controle dos materiais e controle de execução. Além do controle previsto em norma, foram realizados nesta pesquisa outros ensaios em campo. Estes ensaios permitiram monitorar melhor as propriedades geotécnicas, como a resistência e a deformabilidade, das camadas do pavimento com agregado reciclado. Os ensaios complementares realizados foram o Dynamic Cone Penetrometer e o Falling Weight Deflectometer.

Os levantamentos realizados e os resultados apresentados do controle tecnológico em campo são referentes aos 1.020 metros de pista analisados neste trabalho, e não a todo sistema viário da USP Leste.

\subsubsection{Controle tecnológico dos materiais}

O principal objetivo do controle tecnológico é garantir a qualidade do pavimento executado, fundamentando-se nas propriedades físicas e mecânicas dos materiais empregados. No caso da construção do pavimento da USP Leste, foram realizados ensaios em laboratório para diferentes lotes de agregado reciclado. O controle previsto na NBR 15115 (ABNT, 2004), realizado pela empresa fiscalizadora, é apresentado na Tabela 4.7.

Tabela 4.7: Controle tecnológico dos materiais conforme NBR 15115 (ABNT,2004)

\begin{tabular}{|l|l|l|}
\hline \multicolumn{1}{|c|}{ Ensaio } & \multicolumn{1}{c|}{ Detalhamento } & \multicolumn{1}{c|}{ Freqüência } \\
\hline \multirow{2}{*}{$\begin{array}{l}\text { Análise } \\
\text { granulométrica }\end{array}$} & curva granulométrica & a cada lote equivalente a \\
\cline { 2 - 3 } & $\mathrm{C}_{\mathrm{u}}$ & \\
\cline { 2 - 3 } \% passante na peneira $0,42 \mathrm{~mm}$ & \\
\hline \multirow{2}{*}{ Forma dos grãos } & \% de grãos lamelares & $\begin{array}{l}\text { a cada lote equivalente a } \\
700 \mathrm{~m}^{2} \text { de camada acabada }\end{array}$ \\
\hline \multirow{2}{*}{ Compactação } & umidade ótima & $\begin{array}{l}\text { a cada lote equivalente a } \\
2.000 \mathrm{~m}^{2} \text { de camada acabada }\end{array}$ \\
\cline { 2 - 3 } $\begin{array}{l}\text { Índice de suporte } \\
\text { Califórnia }\end{array}$ & de acordo com o tipo de camada & $\begin{array}{l}\text { a cada lote equivalente a } \\
2.000 \mathrm{~m}^{2} \text { de camada acabada }\end{array}$ \\
\hline \multirow{2}{*}{ Expansão } & de acordo com o tipo de camada & $\begin{array}{l}\text { a cada lote equivalente a } \\
2.000 \mathrm{~m}^{2} \text { de camada acabada }\end{array}$ \\
\hline
\end{tabular}


A norma recomenda que sejam determinadas, a cada lote equivalente a $700 \mathrm{~m}^{2}$ de camada acabada, a granulometria e a forma dos grãos do agregado reciclado recebido em obra. De acordo com o projeto do pavimento, para o material ser aplicado, a dimensão característica máxima dos grãos deve ser $50 \mathrm{~mm}$, o coeficiente de uniformidade $\left(\mathrm{C}_{\mathrm{u}}\right)$ deve ser maior que 10 e a porcentagem passante na peneira 0,42mm deve ficar entre $10 \%$ e $40 \%$. Com relação à forma, a norma estabelece que seja aceito no máximo 30\% de grãos lamelares.

Para alguns pontos da pista executada, a empresa fiscalizadora coletou algumas amostras de agregado reciclado após a compactação da camada, e submeteram-nas a ensaios de granulometria. Teve-se como objetivo verificar a quebra de partículas após a compactação em campo.

Com relação à compactação, devem ser realizados ensaios a cada lote equivalente a $2000 \mathrm{~m}^{2}$ de camada acabada, determinando a umidade ótima e o peso específico aparente seco máximo.

A determinação do índice de suporte Califórnia e da expansão do material deve ser realizada a cada lote equivalente a $2000 \mathrm{~m}^{2}$ de camada acabada. Os valores devem estar dentro dos limites fixados pela NBR 15115 (ABNT, 2004), conforme a função na estrutura do pavimento. Para base, o agregado reciclado deve apresentar ISC no mínimo igual a $60 \%$ e expansão no máximo igual a 0,5\%. Para emprego na sub-base, o material deve apresentar ISC no mínimo igual a 20\% e expansão no máximo igual a $1,0 \%$.

As freqüências apresentadas na Tabela 4.7 para realização do controle de materiais devem ser seguidas, em função da usual variabilidade nos agregados reciclados. Contudo, recomenda-se ficar a critério da fiscalização, caso seja verificada necessidade de uma reprodução maior de ensaios.

O controle tecnológico dos materiais recomendado pela PMSP/SP ETS-001 (PMSP, 2003) é bastante similar ao prescrito na NBR 15115 (ABNT, 2004). A única exceção 
é a determinação do coeficiente de curvatura $\left(\mathrm{C}_{\mathrm{c}}\right)$, que deve estar entre 1 e 3 para caracterizar um material bem graduado.

Os resultados obtidos por meio dos relatórios de acompanhamento são apresentados em forma de gráficos e tabelas, indicando a proveniência do material e verificando se atendem ou não o projeto de pavimentação, a NBR 15115 (ABNT, 2004) e a PMSP/SP ETS-001 (PMSP, 2003).

\subsubsection{Controle tecnológico de execução}

Com relação ao emprego do agregado reciclado, o controle tecnológico de execução tem como finalidade verificar se as condições de compactação determinadas e especificadas em laboratório foram atendidas no campo. As especificações de compactação em campo, que exigem a densificação máxima do material, contribuem para a prevenção de excessiva deformação permanente ao longo da vida útil do pavimento (YODER e WITCZAK, 1975).

O acompanhamento da construção das camadas com agregado reciclado foi realizado pela empresa fiscalizadora conforme a NBR 15115 (ABNT, 2004). A Tabela 4.8 apresenta este controle tecnológico exigido.

Tabela 4.8: Controle tecnológico de execução de acordo com a NBR 15115 (ABNT,2004)

\begin{tabular}{|l|l|l|}
\hline \multicolumn{1}{|c|}{ Ensaio } & \multicolumn{1}{c|}{ Detalhamento } & \multicolumn{1}{c|}{ Freqüência } \\
\hline $\begin{array}{l}\text { Determinação } \\
\text { da umidade }\end{array}$ & $\begin{array}{l}\text { utilizar método } \\
\text { expedito normalizado }\end{array}$ & $\begin{array}{l}\text { a cada } 700 \mathrm{~m}^{2} \text { de pista, imediatamente } \\
\text { antes da compactação }\end{array}$ \\
\hline $\begin{array}{l}\text { Grau de } \\
\text { compactação }\end{array}$ & $\begin{array}{l}\text { peso específico } \\
\text { aparente seco } \text { in } \text { situ } \\
\text { (método do frasco de } \\
\text { areia) }\end{array}$ & $\begin{array}{l}\text { a cada } 50 \mathrm{~m} \text { de pista ou a cada } 400 \mathrm{~m}^{2} \\
\text { de camada acabada, imediatamente } \\
\text { após a compactação, alternando borda } \\
\text { direita, eixo e borda esquerda }\end{array}$ \\
\hline
\end{tabular}

Assim, é possível observar que o controle de execução consiste na determinação da umidade de compactação e do grau de compactação. A descrição destes dois procedimentos é feita nos itens 4.5.2.1 e 4.5.2.2. 
O controle tecnológico de execução da PMSP/SP ETS-001 (PMSP, 2003) é semelhante ao prescrito na NBR 15115 (ABNT, 2004), recomendando o uso do método expedito da frigideira para a determinação da umidade.

\subsubsection{Controle da umidade}

A umidade é um parâmetro que exige atenção em relação a seu efeito na capacidade de reduzir os vazios durante a compactação e a sua influência na quebra de agregados reciclados. De acordo com a NBR 15115 (ABNT, 2004), a umidade deve ser verificada a cada $700 \mathrm{~m}^{2}$ de camada acabada, com no mínimo três determinações.

De acordo com os relatórios de acompanhamento elaborados pela empresa fiscalizadora da obra, o controle da umidade foi feito pelo método expedito do fogareiro do Departamento de Estradas de Rodagem (DER), conforme DER M 28-61 (DER, 1961).

Tanto a NBR 15115 (ABNT, 2004), como a PMSP/SP ETS-001 (PMSP, 2003) prescrevem que para liberar a compactação da camada, o teor de umidade da mistura em campo deve estar no intervalo $\pm 1,5 \%$, em relação à umidade obtida com o ensaio de laboratório.

Os resultados obtidos são apresentados em porcentagem, comparando as variações verificadas em relação ao teor de umidade ótima determinado.

\subsubsection{Controle do grau de compactação}

O controle de compactação das camadas de base e sub-base de agregado reciclado foi realizado pela empresa fiscalizadora da obra de acordo com o método de ensaio DNER ME 092/94 (DNER, 1994). Este método emprega o frasco de areia e permite determinar o peso específico aparente in situ, logo após a execução da camada.

Segundo a NBR 15115 (ABNT, 2004) devem ser realizadas no mínimo três determinações, com a seguinte freqüência: a cada $400 \mathrm{~m}^{2}$ de camada acabada ou a cada 50m, alternando borda direita, eixo e borda esquerda. A Figura 4.19 e Figura 
4.20 ilustram o equipamento e um ponto na camada de base de agregado reciclado após o ensaio, respectivamente.

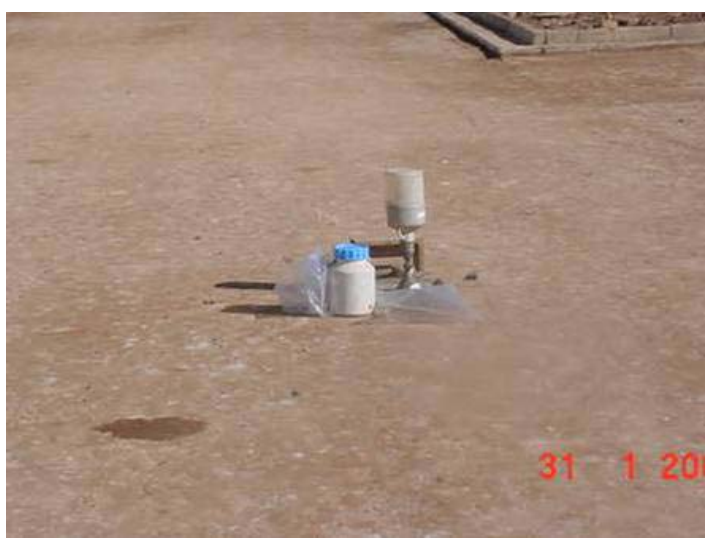

Figura 4.19: Equipamento frasco de areia

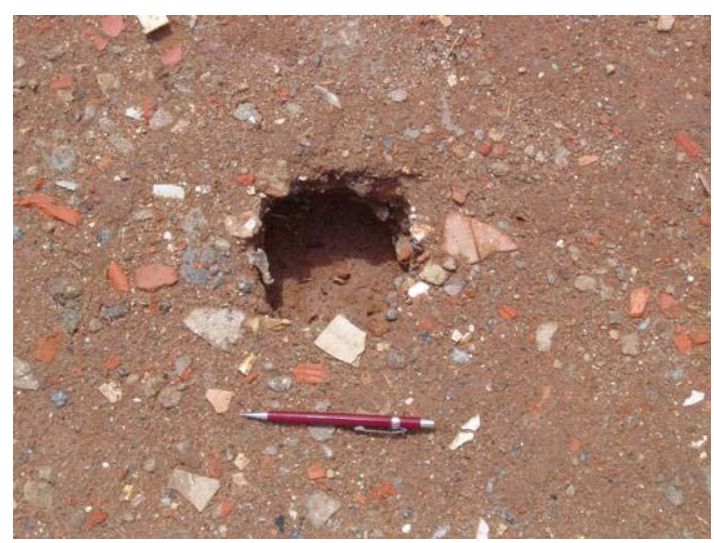

Figura 4.20: Camada de base após ensaio com frasco de areia

Por meio do ensaio do frasco de areia é possível obter o grau de compactação (GC), que é dado pela expressão (14):

$$
G C=\frac{\gamma_{s} \text { campo }}{\gamma_{\text {smáx }} \text { laboratório }} \times 100
$$

onde:

GC: grau de compactação, em [\%];

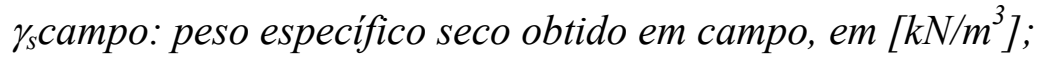

$\gamma_{\text {smáxlaboratório: }}$ peso específico seco máximo obtido em laboratório, em $\left[\mathrm{kN} / \mathrm{m}^{3}\right]$.

Segundo a NBR 15115 (ABNT, 2004), para que a camada executada seja aceita, não deve ser obtido nenhum valor de G.C. menor que 100\%. Caso contrário, deve ser satisfeita a condição representada na equação (15):

$X-K . S \geq 100 \%$

onde:

X: média aritmética dos graus de compactação obtido;

S: desvio padrão; 
K: coeficiente indicado na tabela "valor do coeficiente $K$ para controle estatístico do grau de compactação", disponível na NBR 15115 (ABNT, 2004).

A PMSP/SP ETS-001 (PMSP, 2003) contém as mesmas orientações para a liberação de camadas executadas com agregado reciclado.

Os resultados do grau de compactação obtidos nas camadas de base e sub-base de agregado reciclado são apresentados em porcentagem, verificando se atendem a NBR 15115 (ABNT, 2004).

\subsubsection{Dynamic Cone Penetrometer}

O Dynamic Cone Penetrometer (DCP) foi inicialmente aplicado na avaliação in situ de pavimentos na África do Sul na década de 70 (KLEYN, 1975). Desde então, tem sido muito utilizado no Reino Unido, Austrália, Nova Zelândia e Estados Unidos, destacando-se as pesquisas do U.S. Army Corps of Enginners (Corpo de Engenheiros do Exército Americano) e do Minnesota Department of Transportation (Mn/DOT) (ABU-FARSAKH et al., 2005; SIEKMEIER et al., 1999; TRICHÊS e CARDOSO, 1999).

No Brasil, foram iniciadas as pesquisas sobre o uso e funções do DCP no fim da década de 70 com a Fundação para o Incremento da Pesquisa e do Aperfeiçoamento Industrial (FIPAI). No entanto, a utilização desta técnica ainda tem se limitado a escalas menores (SACHET et al., 2006; TRICHÊS e CARDOSO, 1999).

Geralmente, o ensaio DCP é empregado com a finalidade de caracterizar a capacidade de suporte de solos in situ, em seu estado natural ou compactados, ou de outros materiais em camadas compactadas. Além disso, este ensaio pode ser utilizado no controle tecnológico durante obras de pavimentação, pois permite verificar a espessura das camadas, o grau e a uniformidade da compactação (ABU-FARSAKH et al., 2005; CHEN et al., 2001). 
Segundo Kleyn (1975), o equipamento DCP pode ser empregado em camadas com britas graduadas, contanto que os agregados tenham diâmetro máximo de $75 \mathrm{~mm}$.

A grande vantagem do ensaio DCP é sua rapidez e seu baixo custo, não requerendo a abertura de trincheiras. É um teste comumente denominado de semi-destrutivo (LIVNEH, 1989).

O equipamento DCP consiste em uma barra de aço de $16 \mathrm{~mm}$ de diâmetro e um cone de aço de $20 \mathrm{~mm}$ de diâmetro com abertura de $60^{\circ}$ ou $30^{\circ}$ fixado na extremidade dessa barra. O impacto de um peso de $8 \mathrm{~kg}$, caindo de uma altura padronizada de $575 \mathrm{~mm}$ introduz a barra de $16 \mathrm{~mm}$ no solo até uma profundidade máxima de $800 \mathrm{~mm}$, por impactos sucessivos. Na lateral da barra há uma régua de aço graduada usada para medir a profundidade de penetração do cone para cada série de golpes desejada. Normalmente, não é necessário realizar leituras a cada golpe aplicado. Em solos ou outros materiais mais resistentes, podem ser registradas leituras após vários golpes aplicados (SIEKMEIER et al., 1999; LIMA, 2000; SACHET et al., 2006).

O User Guide to the Dynamic Cone Penetrometer desenvolvido pelo Minnesota Department of Transportation apresenta instruções detalhadas sobre o equipamento DCP, a execução do ensaio e as importantes correlações existentes (Mn/DOT, 1996).

O ensaio de DCP foi empregado no controle tecnológico da USP Leste com o objetivo de verificar a homogeneidade da compactação e as espessuras das camadas executadas. Neste trabalho o ensaio foi desenvolvido conforme a ASTM D 6951 (2003), utilizando cone com abertura de $60^{\circ}$.

Foram realizados ensaios com o DCP diretamente sobre diferentes camadas: base de agregado reciclado, sub-base de agregado reciclado, reforço de subleito de solo laterítico e subleito. A Figura 4.21 e a Figura 4.22 ilustram o equipamento e a execução do ensaio. 


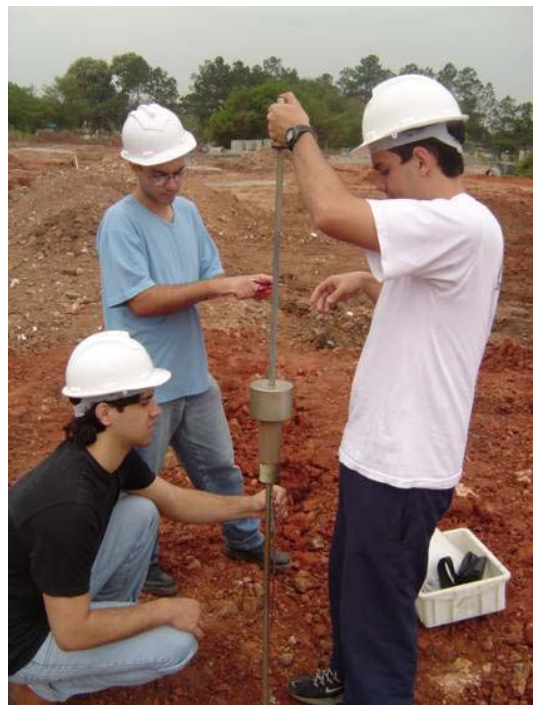

Figura 4.21: Execução do ensaio DCP

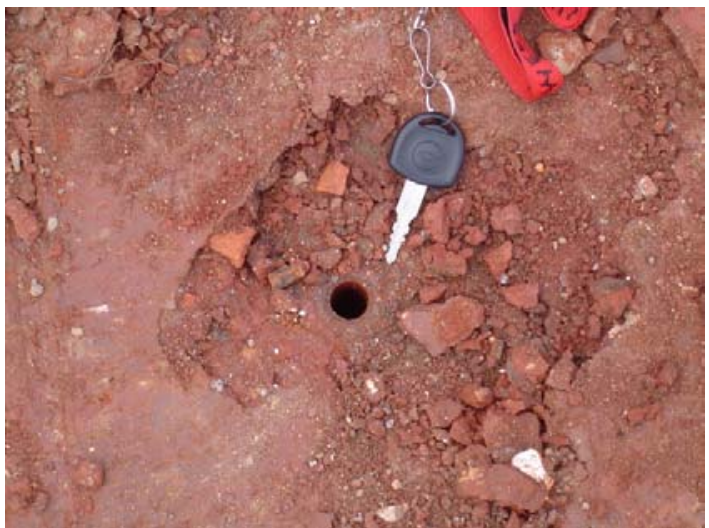

Figura 4.22: Detalhe da superfície após o ensaio DCP sobre camada de reforço de subleito

Por meio do ensaio DCP, é obtido um índice de penetração conhecido por DN ou DPI (DCP Penetration Index). Este índice representa a profundidade atingida pelo golpe aplicado, geralmente expresso em $\mathrm{mm} /$ golpe. Neste trabalho será utilizada a denominação DPI.

O DPI pode ser representado por um gráfico com o número de golpes versus a profundidade penetrada. Este gráfico é conhecido como curva DCP, e indica pela mudança de inclinação da reta, as diferentes resistências entre as camadas do pavimento e suas respectivas espessuras.

O índice de penetração é muito utilizado em correlações com parâmetros de resistências, principalmente com a capacidade de suporte. Muitas pesquisas correlacionaram o DPI com o índice de suporte Califórnia in situ da camada do pavimento, para diferentes materiais.

Neste trabalho, os resultados obtidos com o ensaio DCP são apresentados em forma de gráficos, indicando as espessuras das camadas e os respectivos DPI. Fez-se uma análise estatística verificando a variabilidade do DPI e, conseqüentemente, a homogeneidade da compactação. Além disso, são calculados valores de ISC para os 
materiais que compõem o pavimento, de acordo com equações encontradas na bibliografia consultada.

\subsubsection{Falling Weight Deflectometer}

O Falling Weight Deflectometer (FWD) é um deflectômetro de impacto, do tipo não destrutivo, que permite a avaliação estrutural do pavimento (HUANG, 2004). A ação das cargas do tráfego no pavimento provoca deslocamentos de dois tipos: permanentes e recuperáveis. Os deslocamentos permanentes permanecem mesmo após o fim do carregamento, já os deslocamentos resilientes, ou deflexões recuperáveis, deixam de existir após a remoção da carga. As deflexões recuperáveis representam um indicativo do comportamento elástico da estrutura (PINTO e PREUSSLER, 2002). A Figura 4.23 ilustra a deflexão gerada pela roda de um caminhão atuando sobre a estrutura de um pavimento.

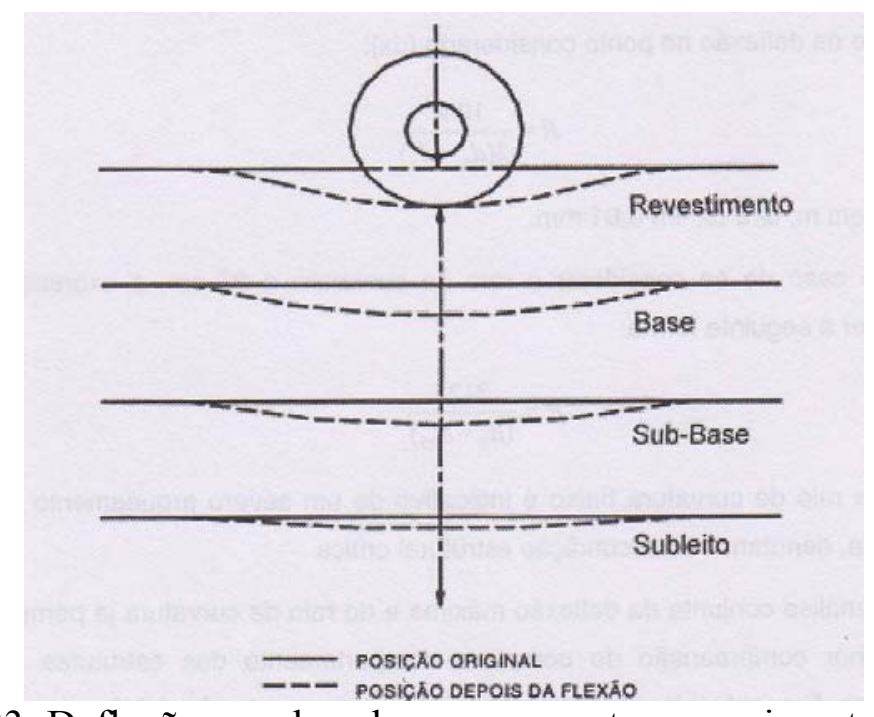

Figura 4.23: Deflexão gerada pelo carregamento no pavimento (PINTO e PREUSSLER, 2002)

Quanto maior o valor da deflexão máxima sofrida pelo pavimento, mais elástica ou resiliente é a estrutura, gerando um maior comprometimento estrutural. No entanto, a análise estrutural deve compreender também a forma da deformada sofrida pelo pavimento. Dessa forma, são medidos os deslocamentos em diferentes pontos de afastamento da carga, obtendo a bacia de deflexão (PINTO e PREUSSLER, 2002). 
Um dos parâmetros mais utilizados na análise da bacia de deflexões é o raio de curvatura. O raio de curvatura é afetado principalmente pelas características elásticas dos componentes da porção superior da estrutura do pavimento, como o revestimento asfáltico e a base. Um raio de curvatura baixo indica uma condição estrutural crítica do pavimento (PINTO e PREUSSLER, 2002). Neste trabalho, para a determinação do raio de curvatura foi utilizada a expressão (16):

$R_{c}=\frac{3125}{d_{0}-d_{25}}$

onde:

$R_{c}:$ raio de curvatura;

$d_{0}$ : deflexão máxima, medida logo abaixo da aplicação da carga, em $\left[10^{-2} \mathrm{~mm}\right]$;

$d_{25}$ : deflexão medida a $25 \mathrm{~cm}$ de afastamento da carga $\left[10^{-2} \mathrm{~mm}\right]$.

O monitoramento do pavimento da USP Leste foi feito de acordo com o procedimento DNER PRO 273/96 (DNER, 1996).

O FWD permite a determinação da bacia de deflexão formada em resposta ao carregamento causado pela queda de um peso padronizado. A bacia de deflexão é registrada por uma série de sensores localizados a distâncias fixas do ponto de aplicação de carga. Para a realização das medições, o veículo é estacionado sobre o local de interesse e os sensores são encostados à superfície e as cargas são aplicadas ao pavimento. A vantagem deste tipo de equipamento está na rapidez da execução, na facilidade de variar a carga aplicada e na simulação mais precisa da solicitação do tráfego (PINTO e PREUSSLER, 2002; HUANG, 2004).

No caso do monitoramento do pavimento do sistema viário do campus da USP Leste, cada bacia de deflexão foi composta por sete pontos. Foram medidas as deflexões nos seguintes pontos de afastamento de aplicação da carga: 0, 20, 30, 45, 65, 90 e $120 \mathrm{~cm}$. Como não foi medida a deflexão a $25 \mathrm{~cm}$ de afastamento, para o cálculo do raio de curvatura foi feita uma interpolação para determinar o $d_{25}$. 
Em relação ao carregamento, foi aplicada uma carga de $46 \mathrm{kN}$, em média. O levantamento deflectométrico na USP Leste foi realizado diretamente sobre a camada de rolamento, ou seja, sobre a camada de concreto asfáltico.

O levantamento deflectométrico com o FWD foi realizado em 27 de novembro de 2006, aproximadamente 20 meses após a execução do primeiro segmento de 240 metros e 8 meses após a conclusão do restante dos 1.020 metros. O levantamento foi executado nos 1.020 metros analisados neste trabalho, correspondentes às seções-tipo $1,2,3$ e 4. Foram medidas as deflexões no eixo, de $10 \mathrm{em} 10$ metros e nas faixas da direta e esquerda, de 20 em 20 metros. O mês de novembro é um período normalmente de muitas chuvas em São Paulo. No entanto, no ano de 2006 apresentou-se excepcionalmente seco.

A Figura 4.24 e a Figura 4.25 apresentam o FWD durante o levantamento deflectométrico no pavimento da USP Leste, realizado sobre a camada de rolamento. O equipamento, o operador e os registros foram gentilmente cedidos pela empresa Dynatest Engenharia Ltda.

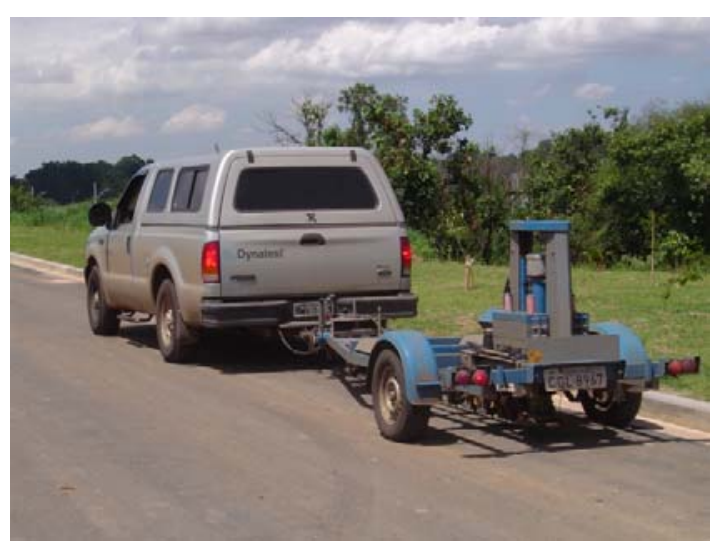

Figura 4.24: Equipamento do tipo FWD

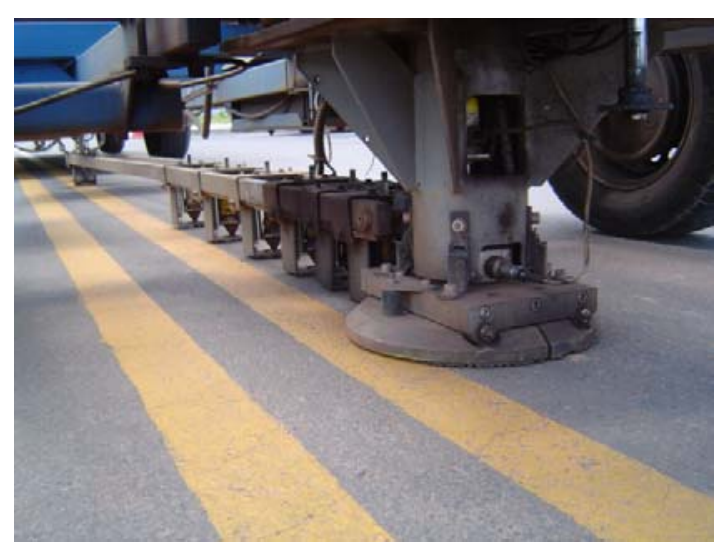

Figura 4.25: Detalhe da aplicação da carga e sensores

Com o monitoramento foi possível analisar, pela bacia de deflexão e pelo raio de curvatura, o comportamento das camadas de base e sub-base com o agregado reciclado de resíduo sólido da construção civil in situ. Além disso, através de 
segmentos homogêneos e do acompanhamento da obra, foi possível verificar os diferentes trechos e analisar as bacias médias separadamente.

Os resultados são apresentados em forma de gráficos, ilustrando as bacias de deflexão média medidas no eixo e nas faixas direita e esquerda para cada segmento homogêneo obtido. São também apresentadas as deflexões médias e os respectivos desvios padrões e os raios de curvatura calculados pela expressão (16), para cada segmento homogêneo analisado.

\subsection{Estudo das bacias de deflexão}

A possibilidade de analisar o comportamento mecânico da estrutura do pavimento é uma das mais importantes utilizações dos parâmetros deflectométricos. Conhecendo as bacias de deflexão representativas de certo segmento homogêneo e as espessuras das camadas constituintes do pavimento, é possível realizar a retroanálise (PINTO e PREUSSLER, 2002).

Por meio de tentativas sucessivas, procura-se determinar o conjunto de módulos de resiliência médios de cada camada que reproduza a mesma bacia de deflexão. Assim, a retroanálise permite a avaliação dos valores de módulo de resiliência das camadas do pavimento, para as suas condições in situ (PINTO e PREUSSLER, 2002).

Existem programas computacionais que resolvem a retroanálise por meio de tentativas, sendo ainda assim um processo bastante trabalhoso. Hoje já existem programas específicos que executam as tarefas iterativas de forma automática, tornando muito mais rápido este processo. Estes programas utilizam a teoria da elasticidade para o cálculo de tensões, deformações e deslocamentos em pavimentos (DNER, 1998).

Para a retroanálise neste trabalho, empregou-se o programa computacional ELSYM5, que é um software específico para avaliações estruturais de pavimentos. Este programa faz os cálculos por diferenças finitas e pressupõe que os materiais comportem-se segundo a elasticidade linear. O ELSYM5 tem sido um dos programas 
computacionais mais utilizados no meio rodoviário. A sua vantagem em relação à maioria dos programas dessa natureza é que o carregamento do sistema elástico pode ser constituído por até dez cargas iguais, situadas em pontos quaisquer da superfície do pavimento (PINTO e PREUSSLER, 2002). Contudo, o ELSYM5 não faz as tarefas iterativas automaticamente, o que torna a retroanálise mais demorada.

A partir das quatro seções-tipo executadas no sistema viário da USP Leste (Figura 3.2) e das bacias de deflexão medidas, foram realizadas as retroanálises.

O processo de retroanálise foi conduzido da seguinte maneira:

- Retroanálise de todas as bacias medidas no eixo na extensão de 1.020 metros, de 10 em 10 metros (com exceção entre $0,260 \mathrm{~km}$ e $0,330 \mathrm{~km}$, pelo uso do material fresado, item 3.4), onde foram construídas as seções-tipo 1, 2, 3 e 4;

- Retroanálise das bacias de deflexão médias da faixa direita e da faixa esquerda ( 8 bacias de deflexão) para a extensão de 1.020 metros analisada, onde foram construídas as seções-tipo 1, 2, 3 e 4.

O carregamento utilizado nas retroanálises foi o medido pelo equipamento FWD em cada local onde se realizou o ensaio.

O principal objetivo desta etapa foi determinar o módulo de resiliência do agregado reciclado compactado e comparar, nos quatro casos obtidos, as diferenças no comportamento quanto à deformação resiliente. Além disso, foi possível verificar a deformabilidade por retroanálise da base de brita graduada simples e compará-la com a base de agregado reciclado.

Os resultados são apresentados por meio de gráficos, indicando a semelhança entre as bacias calculadas pela retroanálise e as bacias medidas com o FWD. São discutidas ainda as variações nos módulos de resiliência de cada material empregado no pavimento da USP Leste. Para isso foram utilizados os valores de módulos de resiliência médios de cada segmento homogêneo e os respectivos desvios padrões obtidos pela retroanálise das bacias de deflexão medidas no eixo. 


\section{APRESENTAÇÃO E DISCUSSÃO DOS RESULTADOS}

Neste capítulo são apresentados e discutidos os resultados obtidos com o programa experimental de laboratório e de campo. As análises da caracterização física, da compactação e do comportamento mecânico compreendem os ensaios laboratoriais realizados com a amostra de agregado reciclado de Santo André coletada. Em relação ao controle tecnológico, são apresentados os resultados de acompanhamento de campo previsto na NBR 15115 (ABNT, 2004) e os levantamentos com o Dynamic Cone Penetrometer e com o Falling Weight Deflectometer.

\subsection{Caracterização física do agregado reciclado em laboratório}

\subsubsection{Composição do agregado reciclado}

Após o processo de separação e classificação visual, verificou-se que o agregado reciclado de Santo André analisado em laboratório era composto por cinco grupos de materiais: (i) cimentícios (concretos e argamassas), (ii) britas, (iii) telhas e tijolos (materiais cerâmicos), (iv) pisos e azulejos (materiais cerâmicos), e (v) resíduos indesejáveis. Da Figura 5.1(a) à Figura 5.1(f) são ilustrados os materiais dos cinco grupos verificados.

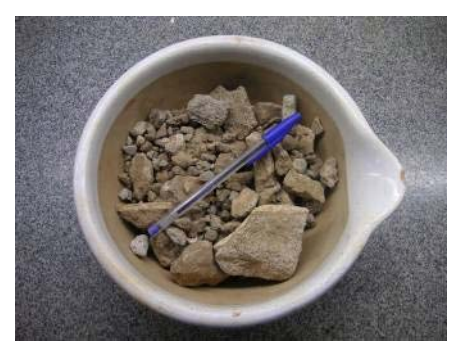

(a) Cimentícios

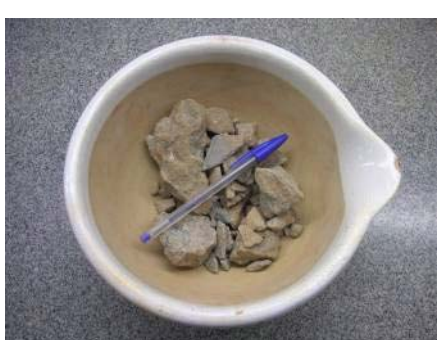

(b) Britas

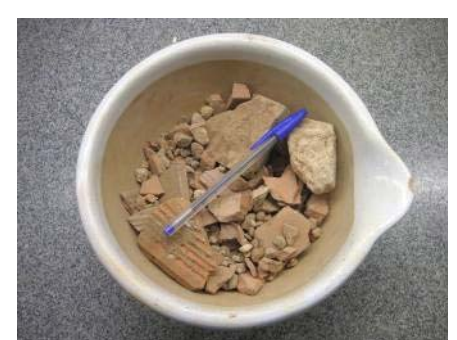

(c) Telhas e tijolos

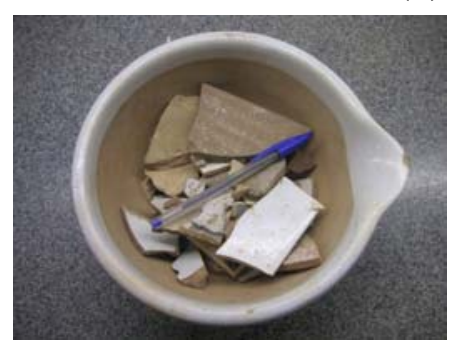

(d) Pisos e azulejos

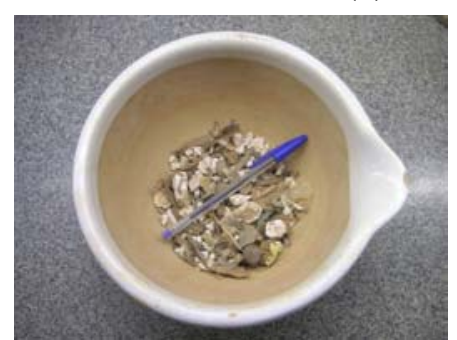

(e) Resíduos indesejáveis

Figura 5.1: Materiais constituintes do agregado reciclado estudado 
Após esta separação por classes, determinou-se a porcentagem em massa de cada material constituinte do agregado reciclado, em relação à fração retida na peneira 4,8mm, desconsiderando a parcela fina. A Figura 5.2 apresenta as porcentagens obtidas para a amostra analisada.

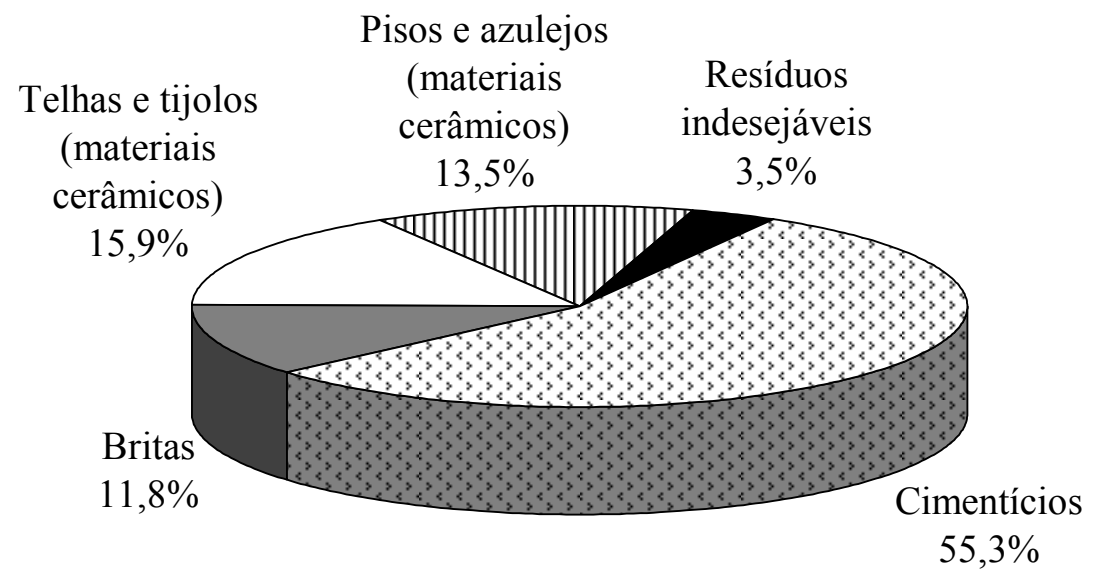

Figura 5.2: Porcentagem em massa dos materiais presentes na fração graúda do agregado reciclado de Santo André analisado em laboratório

Pela Figura 5.2 apresentada, é possível verificar que a maior concentração é de materiais cimentícios $(55,3 \%)$, seguida de materiais cerâmicos $(29,4 \%)$.

O agregado reciclado é denominado misto quando possui na sua fração graúda menos de $90 \%$ em massa de fragmentos à base de materiais cimentícios e rochas. Assim, pode-se considerar o agregado reciclado de Santo André analisado em laboratório do tipo misto.

\subsubsection{Materiais indesejáveis}

A análise visual por catação indicou que o agregado reciclado de Santo André apresenta materiais indesejáveis de diferentes naturezas. Os contaminantes encontrados foram: gesso, amianto, metais, madeira, vidro, plástico, papel, tecido/fibras e isopor.

Verificou-se que a quantidade total em massa de materiais contaminantes presente foi de 1,6\%. Portanto, o agregado reciclado atende a NBR 15115 (ABNT, 2004), já 
que o valor está abaixo do limite de $3 \%$ especificado para materiais de diferentes origens.

É importante ressaltar que a porcentagem de resíduos indesejáveis apresentadas na Figura 5.2 refere-se apenas à fração graúda retida na peneira 4,8 mm. A norma NBR 15115 (ABNT, 2004) estabelece seus limites de contaminantes em massa total, ou seja, considerando também a parcela fina.

\subsubsection{Determinação da massa específica dos grãos}

Os resultados obtidos de massa específica para a amostra de agregado reciclado de Santo André coletada são apresentados separadamente, para os grãos passantes e os grãos retidos na peneira $4,8 \mathrm{~mm}$.

\subsubsection{Grãos passantes na peneira 4,8mm}

As massas específicas dos grãos de agregado reciclado passantes na peneira $4,8 \mathrm{~mm}$ são apresentadas na Tabela 5.1. A umidade do material verificada antes do ensaio era de $8,4 \%$.

Tabela 5.1: Massa específica do agregado reciclado de Santo André relativa aos grãos passantes na peneira 4,8mm

\begin{tabular}{|c|c|}
\hline Número do ensaio & $\begin{array}{c}\text { Massa específica dos grãos } \\
\delta\left[\mathrm{g} / \mathrm{cm}^{3}\right]\end{array}$ \\
\hline 1 & 2,74 \\
\hline 2 & 2,75 \\
\hline
\end{tabular}

Segundo a NBR 6508 (ABNT, 1984), a diferença da massa específica dos grãos obtida para as duas partes analisadas não pode ser maior que $0,02 \mathrm{~g} / \mathrm{cm}^{3}$. Desse modo, conclui-se que o desvio dos resultados é aceitável.

De acordo com Pinto (2000), os valores de massa específica dos grãos para solo situam-se em torno de $2,70 \mathrm{~g} / \mathrm{cm}^{3}$. Sendo este valor adotado sempre quando não se dispõe do valor específico para um determinado solo em estudo. Dessa forma, apesar do material não ser um solo, o resultado obtido com o experimento mostra valores semelhantes aos de solo. 


\subsubsection{Grãos retidos na peneira $4,8 \mathrm{~mm}$}

Este ensaio foi baseado na NBR 6458 (ABNT, 1984), determinando-se a massa específica para cada material constituinte do agregado reciclado de Santo André. A Tabela 5.4 apresenta a massa específica dos grãos retidos na peneira $4,8 \mathrm{~mm}$, de acordo com a natureza do material observada.

Tabela 5.2: Massa específica dos grãos retidos na peneira 4,8 $\mathrm{mm}$ do agregado reciclado de Santo André, de acordo com natureza dos seus constituintes

\begin{tabular}{|c|c|c|}
\hline Natureza do material & Concentração [\%] & $\begin{array}{c}\text { Massa específica dos } \\
\text { grãos } \delta\left[\mathrm{g} / \mathrm{cm}^{3}\right]\end{array}$ \\
\hline Cimentícios & 55,3 & 2,75 \\
\hline Britas & 11,8 & 2,71 \\
\hline Telhas/tijolos (cerâmicos) & 15,9 & 2,55 \\
\hline Pisos/azulejos (cerâmicos) & 13,5 & 2,50 \\
\hline Resíduos indesejáveis & 3,5 & 2,92 \\
\hline
\end{tabular}

Através de uma média ponderada, considerando-se as concentrações apresentadas na Figura 5.2, obteve-se a massa específica do conjunto. Assim, verificou-se que a massa específica dos grãos retidos na peneira $4,8 \mathrm{~mm}$ do agregado reciclado de Santo André é $2,69 \mathrm{~g} / \mathrm{cm}^{3}$.

Observa-se que, como era de se esperar, os materiais retidos na peneira $4,8 \mathrm{~mm}$ tendem a possuir menor massa específica que a média da parcela que passa na peneira $4,8 \mathrm{~mm}$, em conseqüência desta última sofrer redução de porosidade pela britagem ou quebra.

\subsubsection{Absorção}

A determinação da absorção do agregado reciclado de Santo André estudado em laboratório foi baseada na NBR 6458 (ABNT, 1984). Analisou-se separadamente a absorção de cada material constituinte, utilizando-se as mesmas amostras do ensaio de massa específica dos grãos retidos na peneira $4,8 \mathrm{~mm}$. A Tabela 5.3 apresenta os valores de absorção encontrados. 
Tabela 5.3: Absorção dos grãos retidos na peneira 4,8mm do agregado reciclado de Santo André, de acordo com natureza dos seus constituintes

\begin{tabular}{|c|c|c|}
\hline Natureza do material & Concentração [\%] & Absorção [\%] \\
\hline Cimentícios & 55,3 & 11,5 \\
\hline Britas & 11,8 & 3,8 \\
\hline Telhas/tijolos & 15,9 & 20,7 \\
\hline Pisos/azulejos & 13,5 & 11,1 \\
\hline Resíduos indesejáveis & 3,5 & 18,4 \\
\hline
\end{tabular}

Analisando a Tabela 5.3 verifica-se a grande diferença de absorção entre os materiais constituintes do agregado reciclado. Materiais cerâmicos, como telhas e tijolos, apresentam uma absorção muito elevada, comparados com britas. Este fato evidencia a importância da determinação dos constituintes do agregado reciclado, pois quanto mais material cerâmico, mais poroso será o conjunto. Por meio de uma média ponderada utilizando-se as concentrações de cada material constituinte, verificou-se que a absorção da fração graúda do agregado reciclado de Santo André é de 12,2\%.

A Tabela 5.4 apresenta valores de absorção encontrados na bibliografia para agregados reciclados de diferentes composições.

Tabela 5.4: Teor de absorção para fração graúda de agregados reciclados

\begin{tabular}{|c|c|c|c|}
\hline $\begin{array}{l}\text { Composição do } \\
\text { agregado reciclado }\end{array}$ & Procedência & $\begin{array}{c}\text { Absorção } \\
{[\%]}\end{array}$ & Autor \\
\hline Misto & Santo André/SP & 12,2 & Esta pesquisa \\
\hline Misto & Salvador/BA & 8,2 & Carneiro et al. (2001) \\
\hline Misto & Maceió/AL & 6,0 & Vieira et al. (2004) \\
\hline Misto & São Paulo/SP & 7,8 & Motta (2005) \\
\hline Cerâmico & $\begin{array}{l}\text { Hong Kong } \\
\text { China }\end{array}$ & $19,0^{(\mathrm{f})}$ & Poon e Chan (2006) \\
\hline Cimentícia & $\begin{array}{c}\text { Florida } \\
\text { Estados Unidos }\end{array}$ & $4,4^{(\mathrm{g})}$ & Chini et al. (2001) \\
\hline
\end{tabular}

Assim, de acordo com a Tabela 5.4 é possível verificar que agregados reciclados de composição cerâmica apresentam absorção significativamente maior que agregados de composição cimentícia. Em função da forte presença de resíduos de argamassa no 
agregado reciclado desta pesquisa, este apresentou absorção na fração cimentícia maior que o de Chini et al. (2001).

Comparando agregados do tipo misto, a absorção do agregado reciclado de Santo André apresentou-se um pouco mais elevada em relação à de outras pesquisas. Este fato pode ser explicado em conseqüência das diferentes concentrações de materiais presentes nos diferentes agregados reciclados mistos, que influem diretamente na sua capacidade de absorção.

\subsubsection{Análise granulométrica}

Para determinar a granulometria original da amostra de agregado reciclado de Santo André estudada em laboratório, realizou-se um ensaio de acordo com a NBR 7181 (ABNT, 1984). Selecionou-se uma amostra acondicionada em saco plástico e lavouse o material na peneira $0,075 \mathrm{~mm}$. A Tabela 5.5 apresenta as peneiras utilizadas e as frações retidas.

Tabela 5.5: Aberturas das peneiras e respectivas porcentagens passantes verificadas para o agregado reciclado de Santo André

\begin{tabular}{|c|c|}
\hline Abertura da peneira [mm] & Porcentagem passante \\
\hline 50,0 & 100,0 \\
\hline 38,0 & 89,9 \\
\hline 25,0 & 79,4 \\
\hline 19,0 & 72,9 \\
\hline 9,50 & 60,4 \\
\hline 4,80 & 53,2 \\
\hline 2,00 & 44,5 \\
\hline 1,20 & 39,3 \\
\hline 0,60 & 28,3 \\
\hline 0,42 & 21,2 \\
\hline 0,25 & 14,4 \\
\hline 0,15 & 8,9 \\
\hline 0,075 & 5,0 \\
\hline
\end{tabular}

Pela Tabela 5.5 apresentada, é possível verificar que o agregado reciclado de Santo André aqui analisado passa totalmente pela peneira de 50,0mm. A NBR 15115 (ABNT, 2004) prescreve que o agregado reciclado deve ter uma dimensão característica máxima de $63,5 \mathrm{~mm}$. Entretanto, por uma especificação de projeto o 
agregado reciclado utilizado no pavimento da USP Leste deve ter dimensão característica máxima de $50,0 \mathrm{~mm}$. No caso do agregado reciclado aqui estudado, ele se enquadra na Faixa B do Manual de Pavimentação do Departamento Nacional de Infra-estrutura de Transportes (DNIT, 2006). A Figura 5.3 apresenta a curva granulométrica inicial do agregado reciclado de Santo André estudado em laboratório e a Faixa B do DNIT.

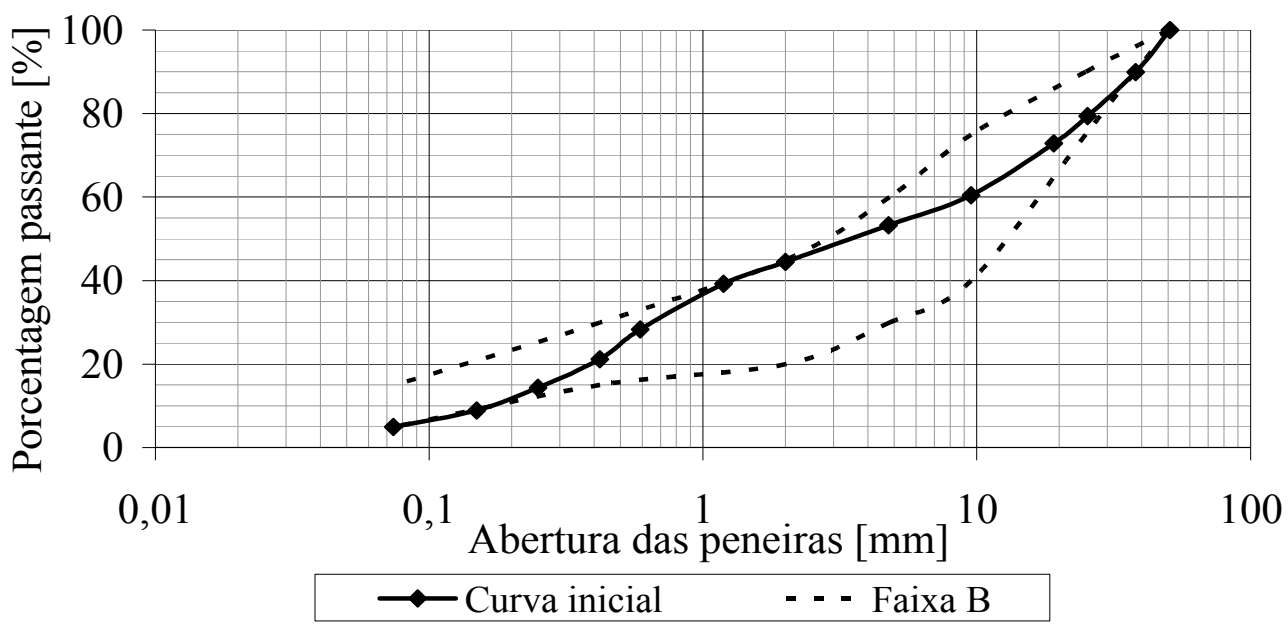

Figura 5.3: Granulometria inicial do agregado reciclado de Santo André

Complementando a análise granulométrica, foram determinados os coeficientes de uniformidade $\left(\mathrm{C}_{\mathrm{u}}\right)$ e de curvatura $\left(\mathrm{C}_{\mathrm{c}}\right)$. Além disso, verificou-se a porcentagem passante na peneira $0,42 \mathrm{~mm}$. A Tabela 5.6 apresenta estes valores obtidos para o agregado reciclado de Santo André e os limites fixados pela NBR 15115 (ABNT, 2004) e pela PMSP/SP ETS-001 (PMSP, 2003).

Tabela 5.6: Aspectos e limites fixados pela norma e especificação brasileiras com relação à granulometria

\begin{tabular}{|c|c|c|c|c|}
\hline Autor & $\begin{array}{c}\text { Dimensão } \\
\text { característica máxima } \\
\text { dos grãos [mm] }\end{array}$ & $\begin{array}{c}\text { Porcentagem que } \\
\text { passa na peneira } \\
0,42 \mathrm{~mm}[\%]\end{array}$ & $\mathrm{C}_{\mathrm{u}}$ & $\mathrm{C}_{\mathrm{c}}$ \\
\hline Esta pesquisa & 50,0 & 21,2 & 53 & 0,30 \\
\hline $\begin{array}{c}\text { NBR 15115 } \\
\text { (ABNT, 2004) }\end{array}$ & 63,5 & $10 \leq \mathrm{a} \leq 40$ & $\geq 10$ & $\begin{array}{c}\text { não } \\
\text { consta }\end{array}$ \\
\hline $\begin{array}{c}\text { PMSP/SP } \\
\text { ETS-001 } \\
\text { (PMSP, 2003) }\end{array}$ & 50,0 & $10 \leq \mathrm{a} \leq 30$ & $\geq 10$ & $1 \leq \mathrm{a} \leq 3$ \\
\hline
\end{tabular}


Assim, com relação à dimensão característica máxima, à porcentagem passante na peneira $0,42 \mathrm{~mm} \mathrm{e} \mathrm{C}_{\mathrm{u}}$, o agregado reciclado de Santo André atende tanto a NBR 15115 (ABNT, 2004), como a PMSP/SP ETS-001 (PMSP, 2003). Quanto ao $\mathrm{C}_{c}$, que não é contemplado na NBR 15115 (ABNT, 2004), a amostra estudada não atende a PMSP/SP ETS-001 (PMSP, 2003). Desse modo, o agregado reciclado encontra-se desuniforme, mas não bem graduado.

Para a moldagem de corpos-de-prova cilíndricos com 150mm de diâmetro e 300mm de altura foi utilizada esta distribuição granulométrica apresentada na Figura 5.3. Foram separadas várias amostras de agregado reciclado de Santo André acondicionadas em sacos plásticos e, por peneiramento, dividiu-se o material em cinco frações. A granulometria foi composta de acordo com esta curva original do material.

\subsubsection{Análise da forma}

A determinação da forma foi feita de acordo com a norma NBR 6954 (ABNT, 1989) utilizando-se quatro frações do material: retido na peneira 38, 25, 19 e 9,5mm. A Tabela 5.7 apresenta as formas e as respectivas porcentagens observadas na amostra analisada.

Tabela 5.7: Forma dos grãos e respectivas porcentagens para o agregado reciclado de Santo André estudado em laboratório

\begin{tabular}{|c|c|}
\hline Classificação da forma & Presença [\%] \\
\hline Cúbica & 55,7 \\
\hline Alongada & 5,5 \\
\hline Alongada-lamelar & 0 \\
\hline Lamelar & 38,8 \\
\hline
\end{tabular}

De acordo com a Tabela 5.7 verifica-se que para a amostra analisada há uma predominância de grãos com forma cúbica, 55,7\%. Contudo, o material não se encontra de acordo com a NBR 15115 (ABNT, 2004), que recomenda para o agregado reciclado até $30 \%$ de grãos lamelares. Além disso, é possível observar a pouca presença de partículas alongadas e a ausência de partículas alongadalamelares. 
Quanto à análise da forma de acordo com a natureza dos materiais, a Tabela 5.8 apresenta os resultados obtidos.

Tabela 5.8: Forma dos grãos de acordo com a natureza para o agregado reciclado de

\begin{tabular}{|c|c|c|c|}
\hline $\begin{array}{c}\text { Satureza do } \\
\text { material }\end{array}$ & Cúbica [\%] & $\begin{array}{c}\text { Alongada } \\
{[\%]}\end{array}$ & Lamelar [\%] \\
\hline Cimentícia & 63,4 & 18,2 & 15,4 \\
\hline Rochosa & 20,5 & 9,1 & 5,1 \\
\hline Telhas/Tijolos & 15,2 & 54,5 & 29,5 \\
\hline Pisos/Azulejos & 0,9 & 18,2 & 50,0 \\
\hline
\end{tabular}

Dessa forma, pode-se concluir que os grãos de forma cúbica são em sua maioria de natureza cimentícia ou rochosa. Já a forma lamelar é predominante nas partículas de materiais cerâmicos, como as telhas, tijolos, pisos e azulejos. A fração alongada, pouco presente na amostra analisada, também ocorreu principalmente nos grãos de natureza cerâmica.

\subsection{Ensaio de compactação em laboratório}

O agregado reciclado de Santo André aqui estudado foi submetido ao ensaio de compactação descrito na norma da ABNT, a NBR 7182 (ABNT, 1986).

Além da determinação da umidade ótima e do peso específico aparente seco máximo, foi analisada a influência da compactação na granulometria e na forma das partículas do agregado reciclado estudado em laboratório.

\subsubsection{Determinação da umidade ótima e peso específico aparente seco máximo}

Foram realizados dois ensaios de compactação, em duas energias diferentes: intermediária e modificada.

De acordo com a NBR 6457 (ABNT, 1986), que prescreve a preparação de amostras de solo para ensaios de compactação, um material pode ter sua fração retida na peneira $19,0 \mathrm{~mm}$ substituída desde que esta porcentagem não seja superior a $30 \%$. No 
caso do agregado reciclado de Santo André aqui analisado, a porcentagem retida nesta peneira é de aproximadamente $28 \%$, o que permitiu a sua substituição.

Para criar uma composição granulométrica, esta quantidade de $28 \%$ retida na peneira 19,0mm foi substituída em peso por materiais pertencentes à fração compreendida entre 19,0 e 4,8mm. A Figura 5.4 apresenta a curva granulométrica original e a composição criada.

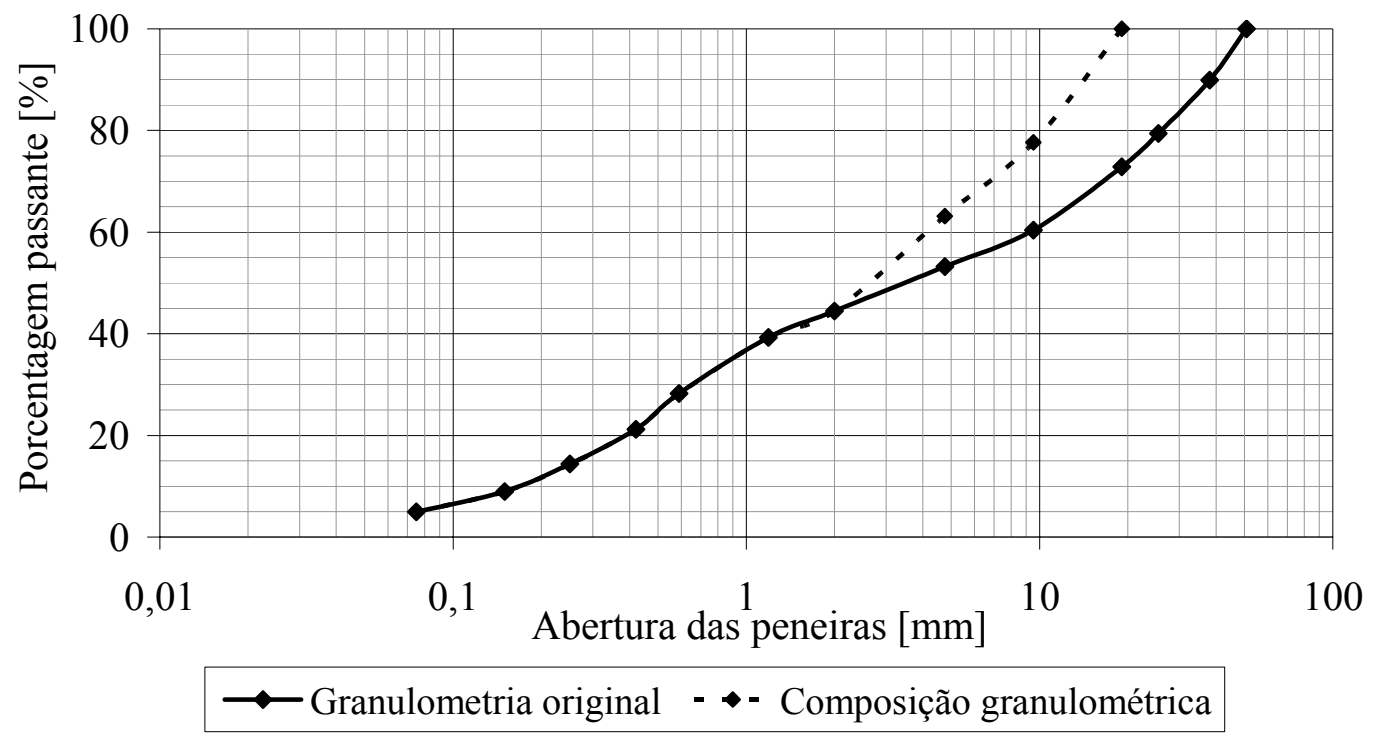

Figura 5.4: Composição granulométrica para ensaios com substituição de material

Cada corpo-de-prova moldado para o ensaio de compactação teve sua granulometria composta conforme a curva granulométrica apresentada na Figura 5.4, ou seja, com substituição de material.

Durante a realização de cada ensaio de compactação foram moldados cinco corposde-prova, sem reuso do material. A NBR 7182 (ABNT, 1986) diz que para obter a curva de compactação são necessários cinco pontos, sendo dois no ramo seco, um próximo à umidade ótima e dois no ramo úmido da curva.

Por meio dos ensaios de compactação foram obtidas duas curvas com o formato típico de sino. Este fato deve ser destacado, pois de acordo com a literatura revisada, é muito difícil determinar a umidade ótima de agregados reciclados (MOLENAAR e 
NIEKERK, 2002; O’MAHONY e MILLIGAN, 1991). Em função da grande variabilidade das amostras, os resultados com agregados reciclados são em geral muito dispersos, dificultando a obtenção de uma curva de compactação.

As curvas de compactação obtidas e as curvas de saturação correspondentes a $100 \%$ e 90\% são apresentadas na Figura 5.5.

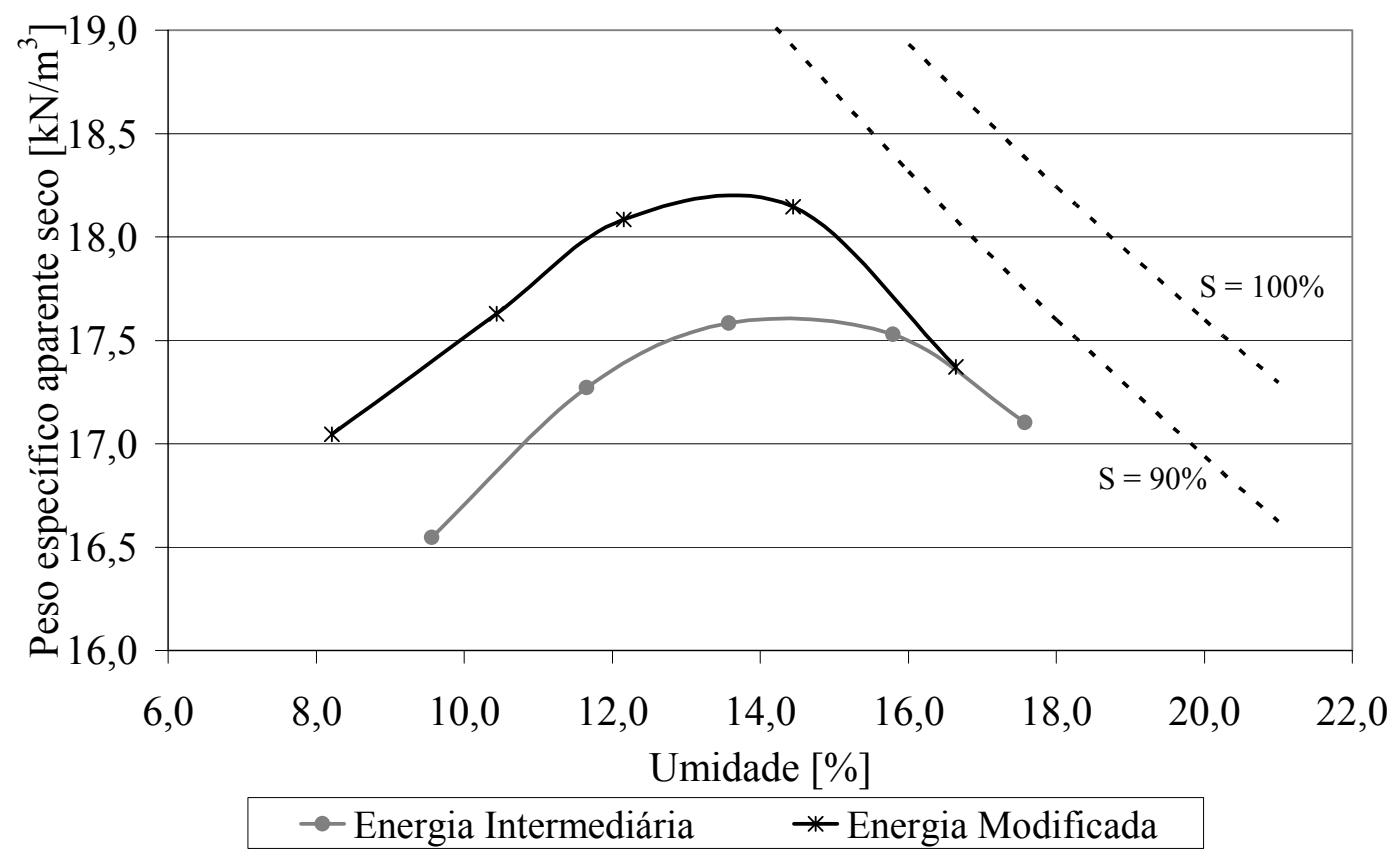

Figura 5.5: Curvas de compactação para energias intermediária e modificada

Pela Figura 5.5 é possível verificar que a curva de compactação para energia modificada apresenta uma umidade ótima menor e um peso específico aparente seco maior em relação à curva para energia intermediária. Foram obtidas umidades ótimas de $13,5 \%$ e $14,6 \%$ e pesos específicos aparentes secos máximos de $18,2 \mathrm{kN} / \mathrm{m}^{3}$ e $17,6 \mathrm{kN} / \mathrm{m}^{3}$ para energia modificada e intermediária, respectivamente.

A Tabela 5.9 apresenta valores encontrados na bibliografia para agregados reciclados de diferentes composições e origens. 
Tabela 5.9: Valores de peso específico seco máximo e umidade de compactação encontrados para agregados reciclados

\begin{tabular}{|c|c|c|c|c|c|}
\hline $\begin{array}{c}\text { Composição } \\
\text { do agregado } \\
\text { reciclado }\end{array}$ & Procedência & $\begin{array}{l}\text { Energia de } \\
\text { compactação }\end{array}$ & $\begin{array}{c}\text { Peso } \\
\text { específico } \\
\text { aparente } \\
\text { seco } \\
\text { máximo } \\
{\left[\mathrm{kN} / \mathrm{m}^{3}\right]}\end{array}$ & $\begin{array}{c}\text { Umidade } \\
\text { obtida } \\
\text { [\%] }\end{array}$ & Autor \\
\hline \multirow{2}{*}{ Misto } & \multirow{2}{*}{$\begin{array}{c}\text { Santo André } \\
\text { Brasil }\end{array}$} & Intermediária & 17,6 & 14,6 & \multirow{2}{*}{$\begin{array}{c}\text { Esta } \\
\text { pesquisa }\end{array}$} \\
\hline & & Modificada & 18,2 & 13,5 & \\
\hline \multirow{2}{*}{ Misto } & \multirow{2}{*}{$\begin{array}{c}\text { Rio de } \\
\text { Janeiro } \\
\text { Brasil }\end{array}$} & Intermediária & 18,3 & 13,8 & \multirow{2}{*}{$\begin{array}{l}\text { Fernandes } \\
(2004)\end{array}$} \\
\hline & & Modificada & 18,5 & 12,5 & \\
\hline Misto & $\begin{array}{c}\text { São Paulo } \\
\text { Brasil } \\
\end{array}$ & Intermediária $^{(\mathrm{h})}$ & 18,3 & 11,0 & $\begin{array}{l}\text { Motta } \\
(2005) \\
\end{array}$ \\
\hline \multirow{2}{*}{ Misto } & \multirow{2}{*}{$\begin{array}{l}\text { Uberlândia } \\
\text { Brasil }\end{array}$} & Intermediária & 19,8 & 9,3 & \multirow{2}{*}{$\begin{array}{l}\text { Moreira et } \\
\text { al. }(2006)\end{array}$} \\
\hline & & Modificada & 20,5 & 9,1 & \\
\hline Concreto & $\begin{array}{l}\text { Estados } \\
\text { Unidos }\end{array}$ & Normal & 18,7 & 5,0 & $\begin{array}{l}\text { Bennert et } \\
\text { al. }(2000)\end{array}$ \\
\hline Concreto & Austrália & Modificada & 19,6 & 9,5 & $\begin{array}{c}\text { Nataatmadja } \\
\text { e Tan } \\
(2001) \\
\end{array}$ \\
\hline Branco $^{(i)}$ & \multirow{2}{*}{$\begin{array}{l}\text { Goiânia } \\
\text { Brasil }\end{array}$} & \multirow{2}{*}{ Intermediária } & 17,6 & 18,2 & \multirow{2}{*}{$\begin{array}{l}\text { Ribeiro et } \\
\text { al. (2002) }\end{array}$} \\
\hline Vermelho $^{(i)}$ & & & 14,2 & 26,0 & \\
\hline
\end{tabular}

De acordo com os dados apresentados na Tabela 5.9 é possível verificar que os valores de umidade ótima e peso específico aparente seco máximo obtidos com o ensaio são similares às médias que vêm sendo encontradas por outros pesquisadores.

\subsubsection{Influência da compactação}

Nesta pesquisa analisou-se o efeito da compactação em laboratório na granulometria e na forma do agregado reciclado de Santo André.

\subsubsection{Granulometria}

Para avaliar as modificações na granulometria do material, foram realizados dois ensaios de granulometria após a compactação. Foram moldados dois corpos-de-prova 
com $150 \mathrm{~mm}$ de diâmetro e $300 \mathrm{~mm}$ de altura: um na energia intermediária e outro na energia modificada.

O ensaio de granulometria foi feito como o de caracterização. Após a compactação o material foi desmoldado, levemente destorroado e submetido à lavagem na peneira $0,075 \mathrm{~mm}$. A Tabela 5.10 apresenta as peneiras utilizadas e as frações retidas para o material no estado inicial e após a compactação nas energias intermediária e modificada.

Tabela 5.10: Aberturas das peneiras e respectivas porcentagens passantes verificadas para o agregado reciclado de Santo André antes e depois da compactação

\begin{tabular}{|c|c|c|c|}
\hline \multirow{2}{*}{$\begin{array}{c}\text { Abertura da peneira } \\
{[\mathrm{mm}]}\end{array}$} & \multicolumn{3}{|c|}{ Porcentagem passante } \\
\cline { 2 - 4 } & Original & Intermediária & Modificada \\
\hline 50,0 & 100,0 & 100,0 & 100,0 \\
\hline 38,0 & 89,9 & 92,2 & 95,7 \\
\hline 25,0 & 79,4 & 83,5 & 87,5 \\
\hline 19,0 & 72,9 & 77,3 & 80,8 \\
\hline 9,50 & 60,4 & 64,5 & 66,0 \\
\hline 4,80 & 53,2 & 57,4 & 58,5 \\
\hline 2,00 & 44,5 & 49,5 & 50,4 \\
\hline 1,20 & 39,3 & 44,3 & 46,0 \\
\hline 0,60 & 28,3 & 33,4 & 35,0 \\
\hline 0,42 & 21,2 & 24,6 & 28,1 \\
\hline 0,25 & 14,4 & 17,6 & 20,0 \\
\hline 0,15 & 8,9 & 10,9 & 14,6 \\
\hline 0,075 & 5,0 & 6,5 & 10,0 \\
\hline
\end{tabular}

Analisando-se a Tabela 5.10 é possível verificar que ocorreram a compactação influência na granulometria do agregado reciclado. Ocorreram alterações na porcentagem passante em todas as peneiras utilizadas. A quantidade de material fino, passante na peneira $0,075 \mathrm{~mm}$, dobrou após a compactação na energia modificada. Este fato reforça a importância da energia de compactação elevada, obtendo-se a maior quebra dos grãos possível durante a execução. Assim, durante a vida útil do pavimento o problema de degradação se minimiza, evitando possíveis afundamentos ou mesmo rupturas indesejadas. 
A Figura 5.6 apresenta a curva granulométrica original do agregado reciclado de Santo André e depois da compactação nas energias intermediária e modificada.

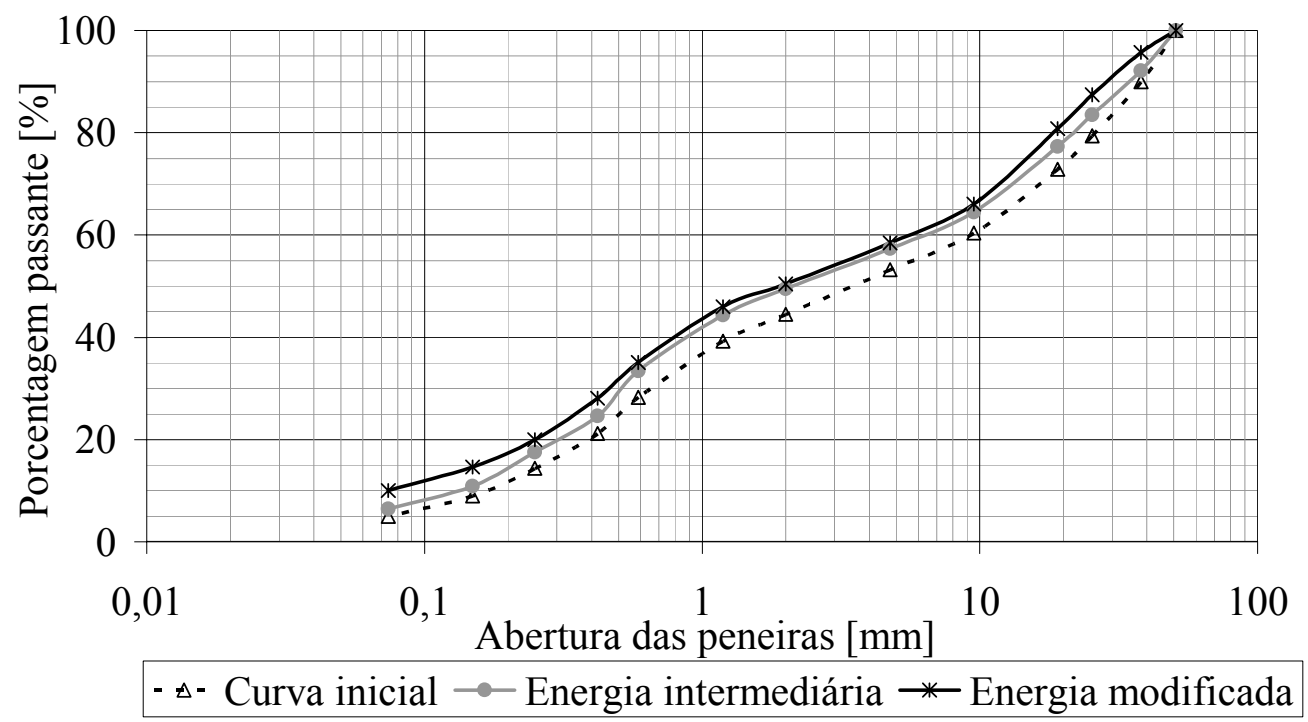

Figura 5.6: Curvas granulométricas do agregado reciclado de Santo André antes e depois da compactação, em relação à porcentagem passante

Para melhor visualizar as modificações granulométricas, é apresentada na Figura 5.7 uma curva granulométrica considerando a porcentagem retida em cada peneira do agregado reciclado de Santo André antes e depois da sua compactação.

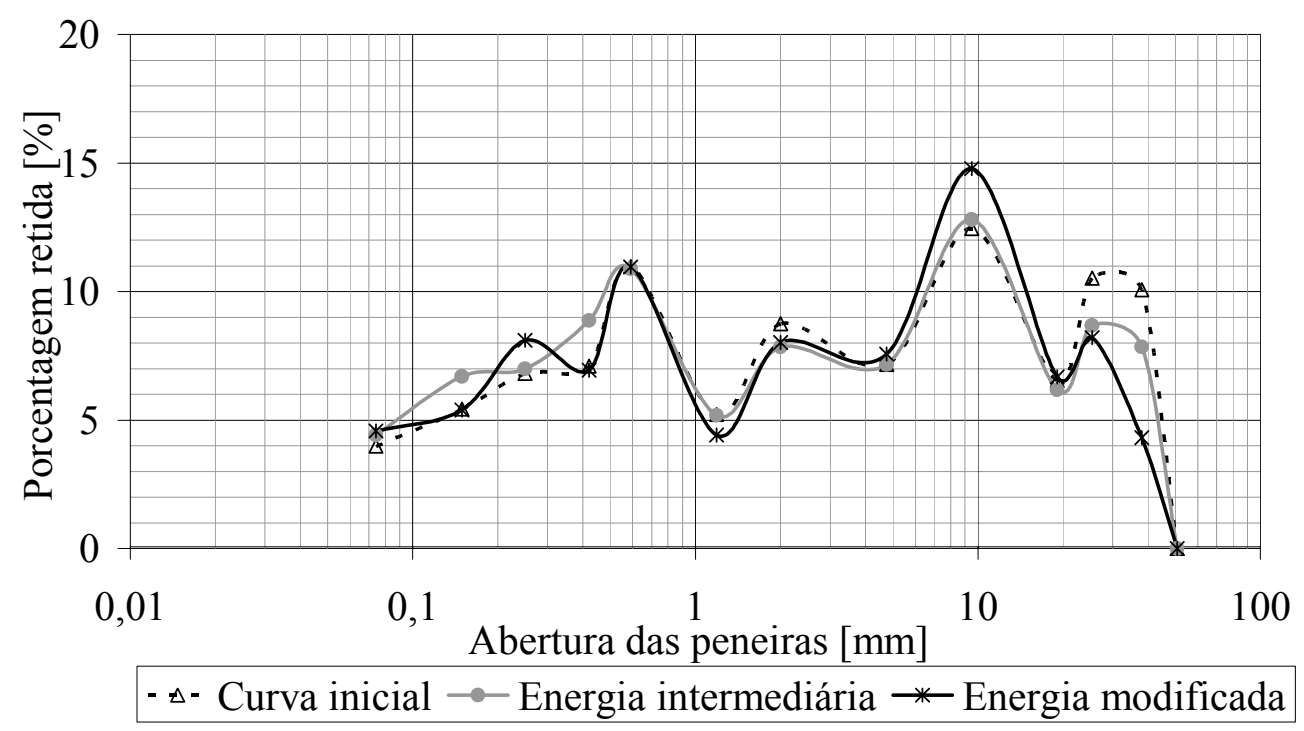

Figura 5.7: Curvas granulométricas do agregado reciclado de Santo André antes e depois da compactação, em relação à porcentagem retida 
Por meio da Figura 5.6 e da Figura 5.7 é possível observar que ocorreram modificações granulométricas após a compactação. Após o emprego da energia intermediária, o agregado reciclado de Santo André sofre quebras e com a aplicação da energia modificada, estas quebras continuam ocorrendo.

A análise desta degradação do agregado é muito importante, pois apesar da NBR 15115 (ABNT, 2004) e da PMSP/SP ETS-001 (PMSP, 2003) prescreverem alguns aspectos referentes à granulometria, durante a aplicação e compactação ocorrem alterações. Assim, um material que não atendesse inicialmente o projeto, poderia após a sua quebra tornar-se de acordo com o especificado.

Apesar da mudança granulométrica após a compactação, o agregado reciclado de Santo André continua dentro dos limites da NBR 15115 (ABNT, 2004) e da PMSP/SP ETS-001 (PMSP, 2003), em relação à porcentagem passante na peneira $0,42 \mathrm{~mm}$ e ao coeficiente de uniformidade $\left(\mathrm{C}_{\mathrm{u}}\right)$. A Tabela 5.11 apresenta os resultados obtidos.

Tabela 5.11: Aspectos e limites fixados pela norma e especificação brasileiras com relação à granulometria

\begin{tabular}{|c|c|c|c|c|}
\hline Autor & $\begin{array}{c}\text { Dimensão } \\
\text { característica } \\
\text { máxima dos grãos } \\
{[\mathrm{mm}]}\end{array}$ & $\begin{array}{c}\text { Porcentagem que } \\
\text { passa na peneira } \\
0,42 \mathrm{~mm}[\%]\end{array}$ & $\mathrm{C}_{\mathrm{u}}$ & $\mathrm{C}_{\mathrm{c}}$ \\
\hline $\begin{array}{c}\text { Esta pesquisa } \\
\text { (condição inicial) }\end{array}$ & 50,0 & 21,2 & 53 & 0,30 \\
\hline $\begin{array}{c}\text { Esta pesquisa } \\
\text { (após intermediária) }\end{array}$ & 50,0 & 25 & 43 & 0,30 \\
\hline $\begin{array}{c}\text { Esta pesquisa } \\
\text { (após modificada) }\end{array}$ & 50,0 & 28 & 74 & 0,50 \\
\hline $\begin{array}{c}\text { NBR 15115 } \\
\text { (ABNT, 2004) }\end{array}$ & 63,5 & $10 \leq \mathrm{a} \leq 40$ & $\geq 10$ & $\begin{array}{c}\text { não } \\
\text { consta }\end{array}$ \\
\hline $\begin{array}{c}\text { PMSP/SP } \\
\text { ETS-001 }\end{array}$ & 50,0 & $\mathrm{a} \leq 30$ & $\geq 10$ & $1 \leq \mathrm{a} \leq 3$ \\
\hline (PMSP, 2003)
\end{tabular}

Observa-se que houve uma significativa alteração nos valores de porcentagem passante na peneira $0,42 \mathrm{~mm}$ e $\mathrm{C}_{\mathrm{u}}$. $\mathrm{O}$ aumento dos valores de $\mathrm{C}_{\mathrm{u}}$ depois da compactação nas energias intermediária e modificada, deve-se a maior quantidade de 
finos passantes nas peneiras de diâmetro equivalente a 10\%. Apesar da modificação granulométrica com a compactação, o agregado reciclado continua não atendendo a PMSP/SP ETS-001 (PMSP, 2003) em relação ao $\mathrm{C}_{\mathrm{c}}$.

Para complementar o estudo das alterações na granulometria, foi determinado o índice de degradação de Ruiz. A Tabela 5.12 apresenta os resultados de ID obtidos após o emprego da energia intermediária e modificada.

Tabela 5.12: Variações de índice de degradação de Ruiz para o agregado reciclado de Santo André de acordo com a energia de compactação

\begin{tabular}{|l|c|c|}
\hline \multirow{2}{*}{\multicolumn{1}{|c|}{ Parâmetros }} & \multicolumn{2}{c|}{ Energia empregada } \\
\cline { 2 - 3 } & Intermediária & Modificada \\
\hline Índice de degradação de Ruiz (ID) & 3,7 & 6,3 \\
\hline Deslocamento máximo & $5,1(\# 0,60 \mathrm{~mm})$ & $8,1(\# 25,0 \mathrm{~mm})$ \\
\hline Deslocamento mínimo & $1,5(\# 0,075 \mathrm{~mm})$ & $5,1(\# 0,075 \mathrm{~mm})$ \\
\hline Desvio padrão & 1,3 & 1,0 \\
\hline
\end{tabular}

Pelos resultados apresentados é possível concluir que o ID cresce com o aumento da energia de compactação. As menores modificações ocorreram na peneira $0,075 \mathrm{~mm}$, tanto para a energia intermediária como para a modificada. Já o deslocamento máximo ocorreu em peneiras diferentes para os dois casos analisados: $0,60 \mathrm{~mm}$ na intermediária e 25,0 $\mathrm{mm}$ na modificada. Além disso, pode-se observar que o deslocamento máximo da curva para a energia intermediária corresponde ao deslocamento mínimo da modificada.

Valle (1994) pesquisou a degradação de solos saprolíticos de granito provenientes do estado de Santa Catarina, materiais comumente utilizados em camadas inferiores de pavimentos. Os resultados de ID encontrados variaram entre 3,6 e 8,9. Comparando estes valores com os obtidos para o agregado reciclado de Santo André, verifica-se que a degradação sofrida foi aproximadamente equivalente a de um material natural. 


\subsubsection{Forma}

Em relação às alterações na forma do agregado reciclado graúdo de Santo André, analisou-se o material após a compactação nas energias intermediária e modificada. Os resultados são apresentados na Tabela 5.13.

Tabela 5.13: Forma dos grãos e porcentagens após compactação em duas energias

\begin{tabular}{|c|c|c|}
\hline Energia empregada & Classificação da forma & Presença [\%] \\
\hline \multirow{4}{*}{ Intermediária } & Cúbica & 68,0 \\
\cline { 2 - 3 } & Alongada & 3,0 \\
\cline { 2 - 3 } & Alongada-lamelar & 0 \\
\cline { 2 - 3 } & Lamelar & 29,0 \\
\hline \multirow{4}{*}{ Modificada } & Cúbica & 69,0 \\
\cline { 2 - 3 } & Alongada & 2,0 \\
\cline { 2 - 3 } & Alongada-lamelar & 0 \\
\cline { 2 - 3 } & Lamelar & 29,0 \\
\hline
\end{tabular}

Pelos dados apresentados é possível verificar que após a compactação o material passa a ter um leve aumento de partículas com forma cúbica, do mesmo modo que diminui a presença de grãos lamelares e alongados. Este fato é decorrente da quebra durante o processo de compactação. Contudo, observa-se que a forma não sofre grandes alterações com o emprego da energia modificada, em relação ao uso da energia intermediária. Este fato demonstra que as alterações mais importantes na forma ocorrem nos primeiros golpes, diferentemente da granulometria, que continua a sofrer modificações com a intensificação da compactação.

\subsection{Comportamento mecânico do agregado reciclado em laboratório}

A análise do comportamento mecânico em laboratório compreendeu os ensaios de índice de suporte Califórnia, módulo de resiliência e deformação permanente. Por meio do ensaio de deformação permanente foi verificada também a teoria do shakedown.

\subsection{1 Índice de suporte Califórnia}

Para determinar o índice de suporte Califórnia foram preparados oito corpos-deprova: quatro na energia intermediária, com umidade de $14,6 \%$, e quatro na energia modificada, com umidade de $13,5 \%$. 
A Tabela 5.14 apresenta os resultados de índice de suporte Califórnia obtidos para o agregado reciclado de Santo André compactado na energia intermediária e modificada após quatro dias de imersão.

Tabela 5.14: Valores de índice de suporte Califórnia obtidos para o agregado reciclado de Santo André compactado na energia intermediária e modificada

\begin{tabular}{|c|c|c|c|c|}
\hline $\begin{array}{c}\text { Energia } \\
\text { empregada }\end{array}$ & $\begin{array}{l}\text { ISC } \\
{[\%]}\end{array}$ & $\begin{array}{c}\text { ISC médio } \\
{[\%]}\end{array}$ & $\begin{array}{c}\text { Desvio } \\
\text { padrão } \\
{[\%]}\end{array}$ & $\begin{array}{c}\text { Coeficiente } \\
\text { de variação } \\
{[\%]}\end{array}$ \\
\hline \multirow{4}{*}{ Intermediária } & 63 & \multirow{4}{*}{73} & \multirow{4}{*}{14} & \multirow{4}{*}{19} \\
\hline & 64 & & & \\
\hline & 72 & & & \\
\hline & 94 & & & \\
\hline \multirow{4}{*}{ Modificada } & 81 & \multirow{4}{*}{117} & \multirow{4}{*}{26} & \multirow{4}{*}{22} \\
\hline & 121 & & & \\
\hline & 124 & & & \\
\hline & 143 & & & \\
\hline
\end{tabular}

As médias dos índices de suporte Califórnia para a energia intermediária e modificada foram $73 \%$ e $117 \%$, respectivamente. No entanto, os dados apresentamse muito dispersivos, em função da heterogeneidade do agregado reciclado e também dos erros inerentes ao ensaio. Além disso, a granulometria do agregado reciclado aqui estudado possui uma quantidade considerável da fração pedregulho, o que influencia na repetibilidade do ensaio. Caso um agregado grande fique embaixo do pistão, a penetração será dificultada, implicando em valores altos de ISC.

Pinto desenvolveu um estudo em 1964 sobre a difícil repetibilidade do experimento de ISC. Neste trabalho foram analisados diferentes tipos de solo brasileiros, envolvendo cálculos de ISC médio, desvio padrão e coeficiente de variação. Em praticamente todos os casos observou-se variações significativas em torno do valor de ISC.

Escolheu-se um dos solos apresentados no estudo de Pinto (1964) para traçar um comparativo com o agregado reciclado da presente pesquisa. Optou-se por um solo cuja classificação HRB (Highway Research Board) corresponde a A 1-b, que atingiu 
ISC médio de $124 \%$ ao ser compactado na energia modificada. Os resultados apontaram que seu desvio padrão foi de $19 \%$ e que seu coeficiente de variação foi de $15 \%$. Pinto constatou dentre outros materiais estudados e pesquisas bilbiográficas valores de coeficiente de variação entre $6,0 \%$ e 33,9\%. Assim, os resultados obtidos para o agregado reciclados de Santo André se enquadram nesta faixa de possível variação.

Confrontando os resultados de ISC obtidos nesta pesquisa para o agregado reciclado de Santo André com os limites preconizados pela NBR 15115 (ABNT, 2004), tem-se que os mesmos satisfazem plenamente a norma. Os valores médios de $73 \%$ e $117 \%$ para as energias intermediária e modificada, respectivamente, atendem o mínimo exigido para emprego em reforço do subleito, sub-base e base (neste último caso, pavimento de baixo volume de tráfego). A Tabela 5.15 apresenta valores de ISC encontrados na bibliografia consultada, para diferentes tipos de agregados reciclados.

Tabela 5.15: Valores índice de suporte Califórnia para diferentes tipos de agregados reciclados

\begin{tabular}{|c|c|c|c|c|c|}
\hline $\begin{array}{c}\text { Composição } \\
\text { do agregado } \\
\text { reciclado }\end{array}$ & Procedência & $\begin{array}{c}\text { Energia de } \\
\text { compactação }\end{array}$ & $\begin{array}{l}\text { Umidade } \\
\text { ótima [\%] }\end{array}$ & $\begin{array}{l}\text { ISC } \\
{[\%]}\end{array}$ & Autor \\
\hline \multirow{2}{*}{ Misto } & \multirow{2}{*}{$\begin{array}{c}\text { Santo André } \\
\text { Brasil }\end{array}$} & Intermediária & 14,6 & $73^{(\mathrm{k})}$ & \multirow{2}{*}{$\begin{array}{c}\text { Esta } \\
\text { pesquisa }\end{array}$} \\
\hline & & Modificada & 13,5 & $117^{(\mathrm{k})}$ & \\
\hline Misto & $\begin{array}{c}\text { Goiânia } \\
\text { Brasil }\end{array}$ & Intermediária & 14,5 & 88 & $\begin{array}{l}\text { Mendes et } \\
\text { al. }(2004)\end{array}$ \\
\hline Misto & $\begin{array}{c}\text { São Paulo } \\
\text { Brasil }\end{array}$ & Intermediária & 11,0 & $75^{(\mathrm{k})}$ & $\begin{array}{l}\text { Motta } \\
(2005)\end{array}$ \\
\hline Concreto & $\begin{array}{l}\text { Estados } \\
\text { Unidos }\end{array}$ & - & - & $\begin{array}{c}94 \text { até } \\
148\end{array}$ & $\begin{array}{c}\text { FHWA } \\
(1997) \\
\end{array}$ \\
\hline Concreto & China & Normal & 11,8 & 66 & $\begin{array}{c}\text { Poon e } \\
\text { Chan (2006) }\end{array}$ \\
\hline Branco $^{(1)}$ & \multirow{2}{*}{$\begin{array}{c}\text { Florianópolis } \\
\text { Brasil }\end{array}$} & \multirow{2}{*}{ Normal } & $12^{(\mathrm{n})}$ & $26^{(\mathrm{n})}$ & \multirow{2}{*}{$\begin{array}{c}\text { Trichês e } \\
\text { Kryckyj } \\
\text { (1999) }\end{array}$} \\
\hline Vermelho $^{(\mathrm{m})}$ & & & $13^{(\mathrm{n})}$ & $24^{(\mathrm{n})}$ & \\
\hline
\end{tabular}

\footnotetext{
(k) Valores médios

(l) Resíduos brancos com predominância de concreto e argamassa

(m) Resíduos vermelhos com predominância de materiais cerâmicos

(n) Valores aproximados
} 
Analisando a tabela apresentada pode-se concluir que os ISC obtidos para o agregado reciclado de Santo André são próximos aos valores verificados para agregados do tipo misto em outros trabalhos. Segundo a FHWA (1997), os valores de ISC para agregado reciclado de concreto apresentam-se entre $94 \%$ e $148 \%$, enquanto para uma brita graduada o ISC típico é de 100\%.

Em função desta variação nos ensaios de índice de suporte Califórnia, recomenda-se que o comportamento mecânico do agregado reciclado seja também avaliado através de outros experimentos.

Com relação à expansão do agregado reciclado em presença de água, durante os ensaios de índice de suporte Califórnia não foi observada nenhuma alteração do material. De acordo com Trichês e Kryckyj (1999), a expansibilidade baixa ou nula dos resíduos de construção civil é um dos grandes atrativos para a utilização deste material em pavimentação.

\subsubsection{Módulo de resiliência}

Para determinar o módulo de resiliência foram utilizados quatro corpos-de-prova com $150 \mathrm{~mm}$ de diâmetro e $300 \mathrm{~mm}$ de altura. Dois corpos-de-prova foram compactados na energia intermediária, com umidade de $14,6 \%$, e dois na energia modificada, com umidade de 13,5\%. A determinação do módulo foi feita de acordo com o método de ensaio DNER-ME 131/94 (DNER, 1994), empregado para solos.

A Figura 5.8 e Figura 5.9 apresentam os gráfico do módulo de resiliência da média dos resultados para os ensaios nas energias intermediária e modificada, para os modelos em função de $\theta$ e em função de $\sigma_{3}$, respectivamente. Juntamente com as figura são apresentados os respectivos modelos, utilizando-se a soma das tensões principais $(\theta)$, apresentado na expressão (10) e $\sigma_{3}$, apresentado na expressão (9). 


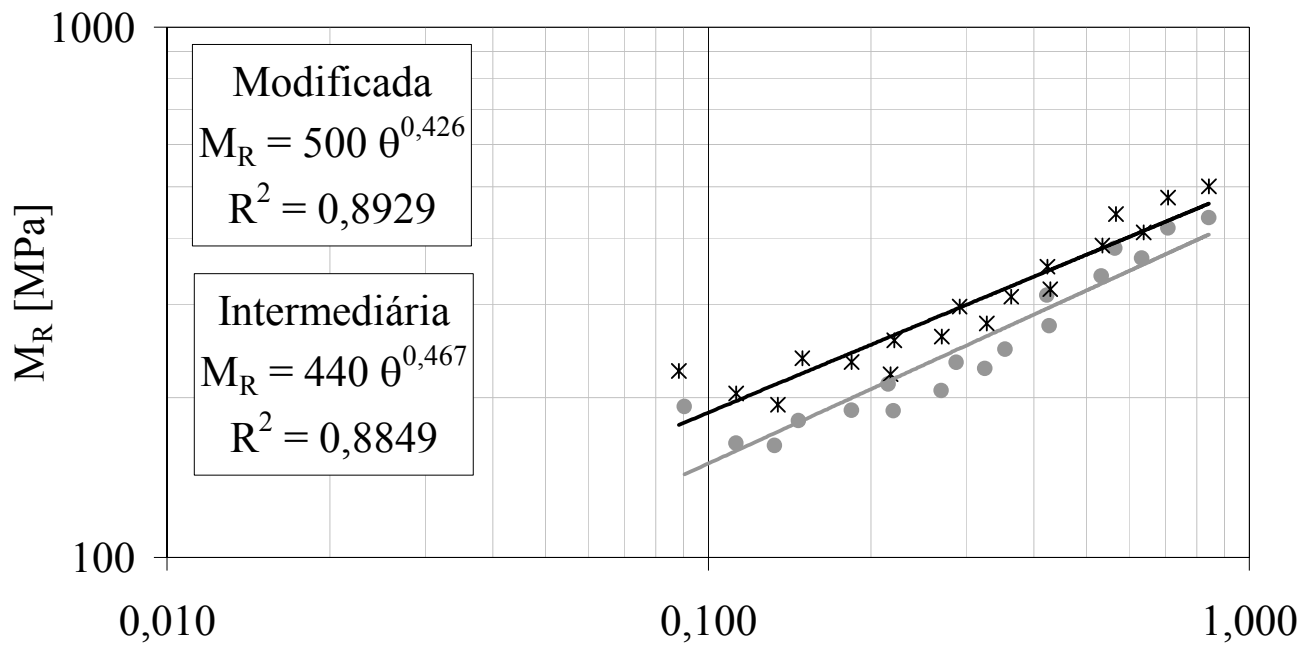

Soma das tensões principais $\theta[\mathrm{MPa}]$

- Energia intermediária * Energia modificada

Figura 5.8: Módulo de resiliência do agregado reciclado de Santo André para corpos-de-prova compactados nas energias intermediária e modificada segundo o modelo em função de $\theta$

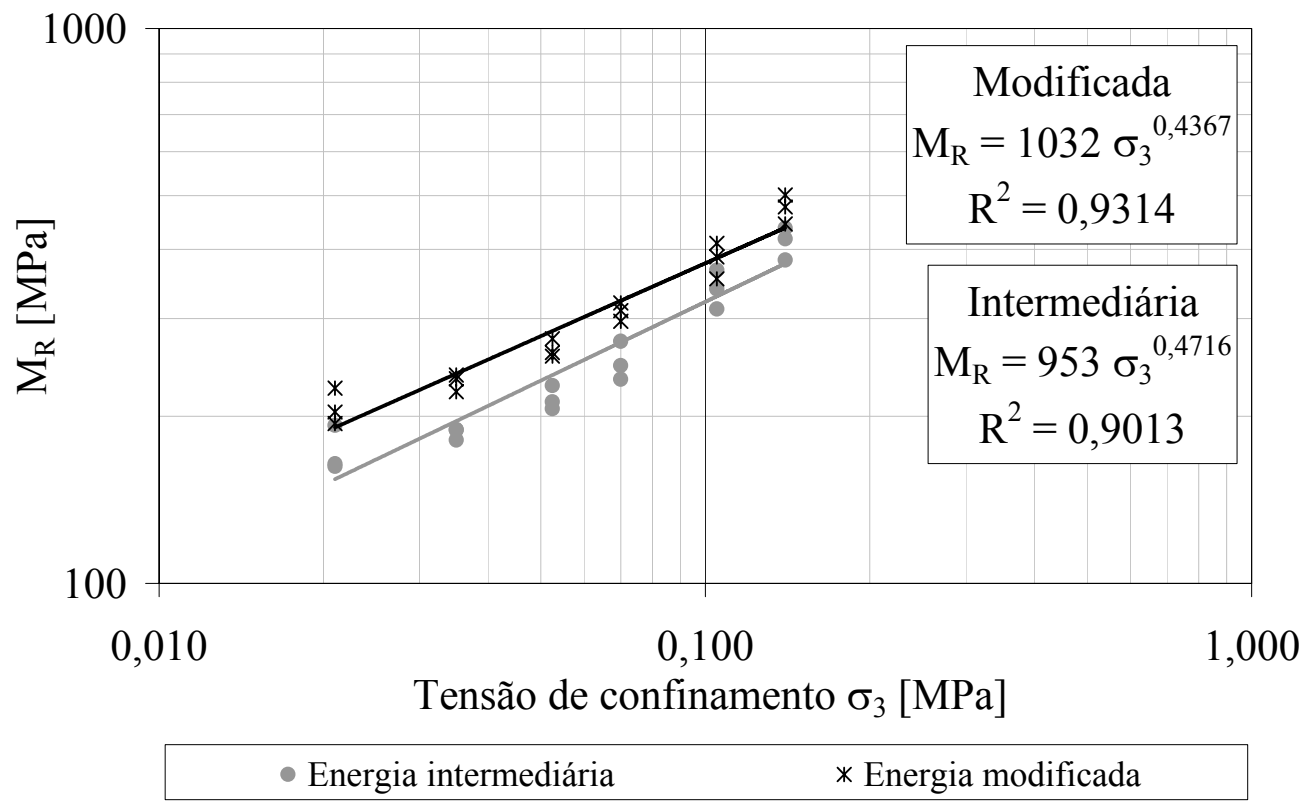

Figura 5.9: Módulo de resiliência do agregado reciclado de Santo André para corpos-de-prova compactados nas energias intermediária e modificada segundo modelo em função de $\sigma_{3}$ 
De acordo com os resultados obtidos, é possível verificar que houve um aumento no valor do módulo de resiliência em função do acréscimo de energia aplicada. $\mathrm{O}$ módulo de resiliência para a energia intermediária variou de $160 \mathrm{MPa}$ a $440 \mathrm{MPa}$, de acordo com o nível de tensões aplicado. Para a energia modificada, o módulo de resiliência ficou entre $200 \mathrm{MPa}$ a $500 \mathrm{MPa}$, de acordo com o nível de tensões aplicado, mostrando uma redução na deformabilidade com o aumento de energia em torno de $10 \%$ a $20 \%$.

Analisando a Figura 5.9 verifica-se ainda que o comportamento mecânico do agregado reciclado é dependente da tensão de confinamento $\left(\sigma_{3}\right)$, em função das inclinações das retas obtidas.

Para visualizar a influência da energia de compactação, é apresentado na Tabela 5.16 valores de módulo de resiliência para o agregado reciclado de Santo André utilizando-se diferentes níveis de tensões. Pelos dados apresentados conclui-se que nesta pesquisa, a compactação na energia modificada implicou em um aumento médio de 16\% no módulo de resiliência, em relação à compactação na energia intermediária.

Tabela 5.16: Comparação de valores de módulo de resiliência para o agregado reciclado de Santo André compactado na energia intermediária e modificada utilizando diferentes níveis de tensões

\begin{tabular}{|c|c|c|c|c|}
\hline $\begin{array}{c}\text { Energia } \\
\text { empregada }\end{array}$ & $\begin{array}{c}\theta \\
{[\mathrm{MPa}]}\end{array}$ & \multirow{2}{*}{$\mathrm{k}_{1}$} & \multirow{2}{*}{$\mathrm{k}_{2}$} & $\begin{array}{c}\mathrm{M}_{\mathrm{R}} \\
{[\mathrm{MPa}]}\end{array}$ \\
\hline \multirow{3}{*}{ Intermediária } & 0,150 & \multirow{3}{*}{440} & \multirow{2}{*}{0,467} & 182 \\
\cline { 2 - 2 } & 0,350 & & 270 \\
\cline { 2 - 2 } & 0,750 & & & 385 \\
\hline \multirow{3}{*}{ Modificada } & 0,150 & \multirow{2}{*}{500} & \multirow{2}{*}{0,426} & 223 \\
\cline { 2 - 3 } & 0,350 & & 320 \\
\cline { 2 - 2 } & 0,750 & & & 442 \\
\hline
\end{tabular}

A Tabela 5.17 apresenta diferentes modelos de módulo de resiliência encontrados na bibliografia consultada, para diferentes tipos de agregados reciclados. 
Tabela 5.17: Modelos de módulo de resiliência obtidos para diferentes tipos de agregados reciclados

\begin{tabular}{|c|c|c|c|c|}
\hline $\begin{array}{c}\text { Composição } \\
\text { do agregado } \\
\text { reciclado }\end{array}$ & Procedência & $\begin{array}{c}\text { Energia de } \\
\text { compactação }\end{array}$ & Modelo obtido & Autor \\
\hline \multirow{2}{*}{ Misto } & \multirow{2}{*}{$\begin{array}{l}\text { Santo } \\
\text { André } \\
\text { Brasil }\end{array}$} & Intermediária & $\mathrm{M}_{\mathrm{R}}=440 \theta^{0,467}$ & \multirow{2}{*}{$\begin{array}{c}\text { Esta } \\
\text { pesquisa }\end{array}$} \\
\hline & & Modificada & $\mathrm{M}_{\mathrm{R}}=500 \theta^{0,426}$ & \\
\hline \multirow{2}{*}{ Misto } & \multirow{2}{*}{$\begin{array}{c}\text { Rio de } \\
\text { Janeiro } \\
\text { Brasil }\end{array}$} & Intermediária & $\mathrm{M}_{\mathrm{R}}=528 \underset{(\mathrm{o})}{\sigma_{3}}{ }^{0,47} \sigma_{\mathrm{d}}^{-0,24}$ & \multirow{2}{*}{$\begin{array}{l}\text { Fernandes } \\
\text { (2004) }\end{array}$} \\
\hline & & Modificada & $\mathrm{M}_{\mathrm{R}}=563 \underset{(\mathrm{o})}{\sigma_{3}}{ }^{0,46} \sigma_{\mathrm{d}}{ }^{-0,26}$ & \\
\hline Concreto & $\begin{array}{l}\text { Estados } \\
\text { Unidos }\end{array}$ & Normal & $\mathrm{M}_{\mathrm{R}}=25,35 \theta^{0,4615(\mathrm{p})}$ & $\begin{array}{l}\text { Bennert et } \\
\text { al. }(2000)\end{array}$ \\
\hline Concreto & Austrália & Modificada & $\mathrm{M}_{\mathrm{R}}=10.387 \theta^{0,5939}$ & $\begin{array}{c}\text { Nataatmadja } \\
\text { e Tan } \\
(2001)\end{array}$ \\
\hline
\end{tabular}

(o) $\mathrm{M}_{\mathrm{R}}, \sigma_{3}, \sigma_{\mathrm{d}}$ em [MPa] / Corpos-de-prova cilíndricos 100mm x 200mm

${ }^{(p)} \mathrm{M}_{\mathrm{R}}$ em $[\mathrm{MPa}]$ e $\theta$ em [kPa] / Corpos-de-prova cilíndricos $150 \mathrm{~mm}$ x $300 \mathrm{~mm}$

(q) $\mathrm{M}_{\mathrm{R}}$ e $\theta \mathrm{em}[\mathrm{kPa}] /$ Corpos-de-prova cilíndricos $100 \mathrm{~mm} \times 200 \mathrm{~mm}$

Analisando a tabela apresentada verifica-se que podem ser utilizados diferentes modelos para avaliar o módulo de resiliência de agregados reciclados. Fernandes (2004) optou pelo modelo composto proposto por Macêdo em $1996^{4}$ onde são utilizados $\sigma_{3}$ e $\sigma_{\mathrm{d}}$. Este modelo apresentou boa correlação tanto para solos argilosos quanto para solos granulares. Contudo, na bibliografia internacional encontra-se geralmente o modelo composto em função de $\theta$, pois este permite a ilustração gráfica considerando tanto $\sigma_{3}$ como $\sigma_{\mathrm{d}}$. A Tabela 5.18 apresenta valores de módulo de resiliência calculados por meio dos modelos apresentados na Tabela 5.17.

\footnotetext{
${ }^{4}$ MACÊDO, J. A. G. Interpretação de ensaios deflectométricos para avaliação estrutural de pavimentos flexíveis - a experiência com FWD no Brasil. Tese (Doutorado) - Coordenação dos Programas de Pós-graduação de Engenharia, Universidade Federal do Rio de Janeiro (COPPE-UFRJ). Rio de Janeiro, 1996.
} 
Tabela 5.18: Módulos de resiliência obtidos para mesmo nível de tensão utilizando os modelos apresentados na Tabela 5.17

\begin{tabular}{|c|c|c|c|c|c|}
\hline Modelo obtido & $\begin{array}{c}\sigma_{\mathrm{d}} \\
{[\mathrm{MPa}]}\end{array}$ & $\begin{array}{c}\sigma_{3} \\
{[\mathrm{MPa}]}\end{array}$ & $\begin{array}{c}\theta \\
{[\mathrm{MPa}]}\end{array}$ & $\begin{array}{c}\mathrm{M}_{\mathrm{R}} \\
{[\mathrm{MPa}]}\end{array}$ & Autor \\
\hline $\mathrm{M}_{\mathrm{R}}=440,39 \theta^{0,467}$ & \multirow{2}{*}{0,140} & \multirow{2}{*}{0,070} & \multirow{2}{*}{0,350} & 270 & \multirow{2}{*}{ Esta pesquisa } \\
\hline $\mathrm{M}_{\mathrm{R}}=500,00 \theta^{0,426}$ & & & & 320 & \\
\hline $\mathrm{M}_{\mathrm{R}}=528 \sigma_{3}^{0,47} \sigma_{\mathrm{d}}^{-0,24}$ & \multirow{2}{*}{0,140} & \multirow{2}{*}{0,070} & \multirow{2}{*}{0,350} & 242 & \multirow{2}{*}{$\begin{array}{c}\text { Fernandes } \\
(2004)\end{array}$} \\
\hline$M_{R}=563 \sigma_{3}^{0,46} \sigma_{d}^{-0,26}$ & & & & 276 & \\
\hline $\mathrm{M}_{\mathrm{R}}=25,35 \theta^{0,4615}$ & 0,140 & 0,070 & 0,350 & 378 & $\begin{array}{c}\text { Bennert et al. } \\
(2000)\end{array}$ \\
\hline $\mathrm{M}_{\mathrm{R}}=10.387 \theta^{0,5939}$ & 0,140 & 0,070 & 0,350 & 337 & $\begin{array}{c}\text { Nataatmadja e } \\
\text { Tan (2001) }\end{array}$ \\
\hline
\end{tabular}

Analisando a Tabela 5.18 é possível verificar que os valores de módulo de resiliência são mais elevados para agregados reciclados de concreto, como no caso de Bennert et al. (2000) e Nataatmadja e Tan (2001). Em relação aos agregados reciclados do tipo misto, observa-se um pequeno aumento nos resultados de $\mathrm{M}_{\mathrm{R}}$ desta pesquisa, em torno de $12 \%$, comparando com os obtidos por Fernandes (2004) para agregados reciclados provenientes do Rio de Janeiro.

A Instrução de Projeto da PMSP-IP-08 (PMSP, 2002) apresenta estimativas de valores de módulo de resiliência para materiais granulares, para que seus projetistas possam avaliar deformações, tensões e deflexões na estrutura do pavimento. De acordo com o documento citado, a estimativa do módulo de para uma camada de base granular apresenta-se entre $100 \mathrm{MPa}$ e $500 \mathrm{MPa}$. Assim, conforme os resultados obtidos nos ensaios aqui realizados, o material poderia ser empregado como uma camada de sub-base e base. No entanto, para este último caso, é importante verificar o comportamento no material em relação a sua deformação permanente. 


\subsubsection{Deformação permanente}

\subsubsection{Deformação permanente}

Os ensaios de deformação permanente foram realizados com cinco corpos-de-prova de agregado reciclado de Santo André estudado em laboratório e um de brita graduada, com $150 \mathrm{~mm}$ de diâmetro e $300 \mathrm{~mm}$ de altura. A análise da deformação permanente foi conduzida até os 100.000 ciclos e foi desenvolvida de três formas:

- Comparação do desempenho do agregado reciclado compactado na energia modificada e intermediária submetido a um mesmo nível de tensões $\left(\sigma_{\mathrm{d}} / \sigma_{3}=\right.$ $6,0)$

- Comparação do desempenho do agregado reciclado compactado na energia modificada submetido a diferentes níveis de tensões $\left(\sigma_{d} / \sigma_{3}=2,0 ; 4,0 ; 6,0\right.$; $6,7)$;

- Comparação do desempenho do agregado reciclado com o de uma brita graduada na mesma graduação do agregado reciclado (após a compactação na energia modificada), compactados na energia modificada e submetidos a um mesmo nível de tensões $\left(\sigma_{d} / \sigma_{3}=2,0\right)$;

A Figura 5.10 ilustra a deformação permanente do agregado reciclado para um nível de tensões $\sigma_{\mathrm{d}} / \sigma_{3}=6,0$ compactado nas energias intermediária e modificada. Este nível de tensões foi o obtido por retroanálise da seção-tipo 3, apresentada no capítulo 3, no topo da camada de base de agregado reciclado. 


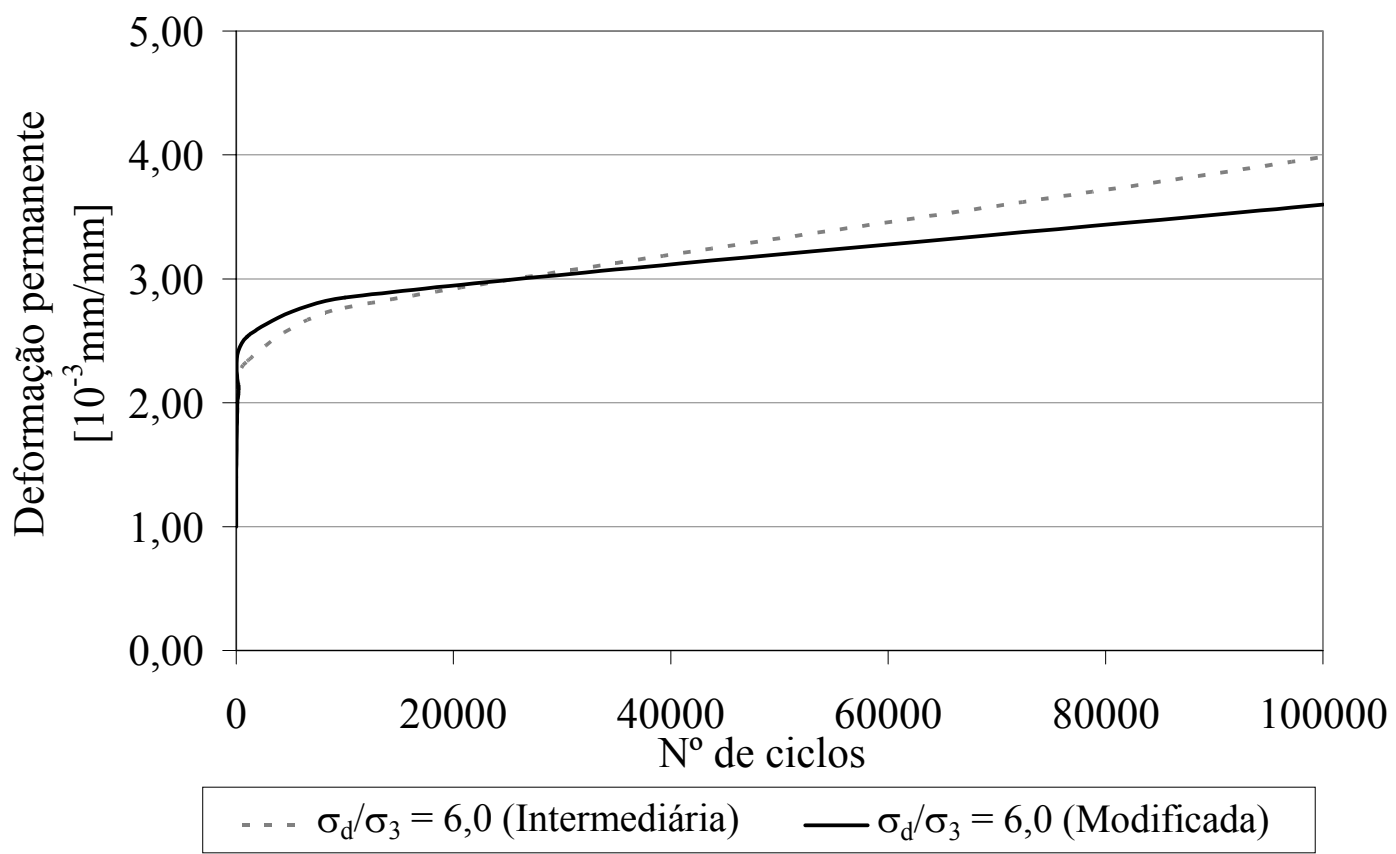

Figura 5.10: Deformação permanente obtida para o agregado reciclado de Santo André compactado na energia intermediária e modificada

Pelo gráfico apresentado, é possível verificar que a energia de compactação empregada influencia na resistência do material à deformação permanente. $O$ agregado reciclado compactado na energia intermediária teve aos 100.000 ciclos uma deformação permanente de $3,98 \times 10^{-3} \mathrm{~mm} / \mathrm{mm}$, enquanto na energia modificada teve uma deformação permanente de $3,60 \times 10^{-3} \mathrm{~mm} / \mathrm{mm}$. Quando bem compactado, o agregado reciclado apresenta uma resistência maior à deformação permanente. Este fato reforça a importância da execução de uma compactação adequada, pois o desempenho do material ao longo de sua vida útil depende do entrosamento entre os grãos e da resistência ao cisalhamento, que por sua vez é tanto maior quanto melhor compactado. Observa-se ainda que não houve uma tendência de estabilização da deformação permanente no agregado reciclado. No entanto, pode-se verificar que para a energia modificada há uma menor tendência de aumento da deformação permanente com o número de repetições de carga.

Na Figura 5.11 é apresentada a deformação permanente do agregado reciclado de Santo André compactado na energia modificada, submetido a quatro níveis de tensão distintos. 


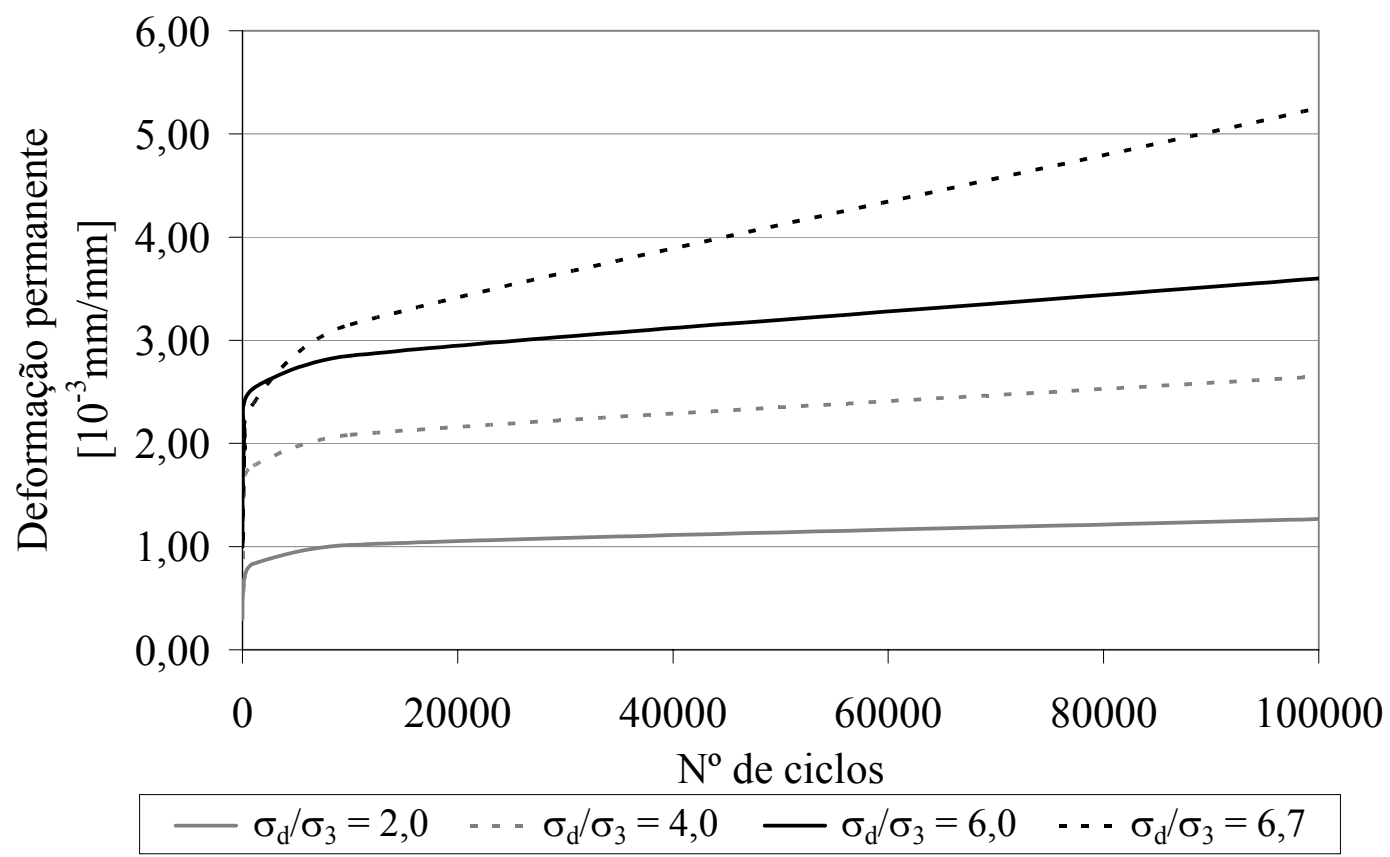

Figura 5.11: Deformação permanente obtida para o agregado reciclado de Santo André compactado na energia modificada submetido a diferentes níveis de tensão

Pelo gráfico apresentado, é possível observar que o nível de tensões influencia no comportamento mecânico do agregado reciclado. A menor deformação permanente verificada aos 100.000 ciclos foi para $\sigma_{d} / \sigma_{3}=2,0\left(1,27 \times 10^{-3} \mathrm{~mm} / \mathrm{mm}\right)$ quando se observou uma tendência a estabilizar a deformação. Já para o nível de tensões $\sigma_{\mathrm{d}} / \sigma_{3}=6,7$, a deformação permanente aumentou consideravelmente $\left(5,25 \times 10^{-3} \mathrm{~mm} / \mathrm{mm}\right)$, lembrando que esta relação procura simular a redução da camada de revestimento asfáltico. Para os níveis de tensões $\sigma_{\mathrm{d}} / \sigma_{3}=4,0$ e $\sigma_{\mathrm{d}} / \sigma_{3}=6,0$, foram observadas deformações permanentes aos 100.000 ciclos de $2,65 \times 10^{-3} \mathrm{~mm} / \mathrm{mm}$ e $3,60 \times 10^{-3} \mathrm{~mm} / \mathrm{mm}$, respectivamente. Estes resultados indicam que para emprego de agregado reciclado em camadas de base é importante que se conheça o nível de tensões que a estrutura estará submetida, para que não ocorram grandes deformações permanentes ao longo da vida útil ou até mesmo a ruptura da estrutura.

Com relação ao comportamento dos diferentes materiais, a Figura 5.12 apresenta a deformação permanente do agregado reciclado de Santo André e da brita graduada na mesma granulometria, compactados na energia modificada. 


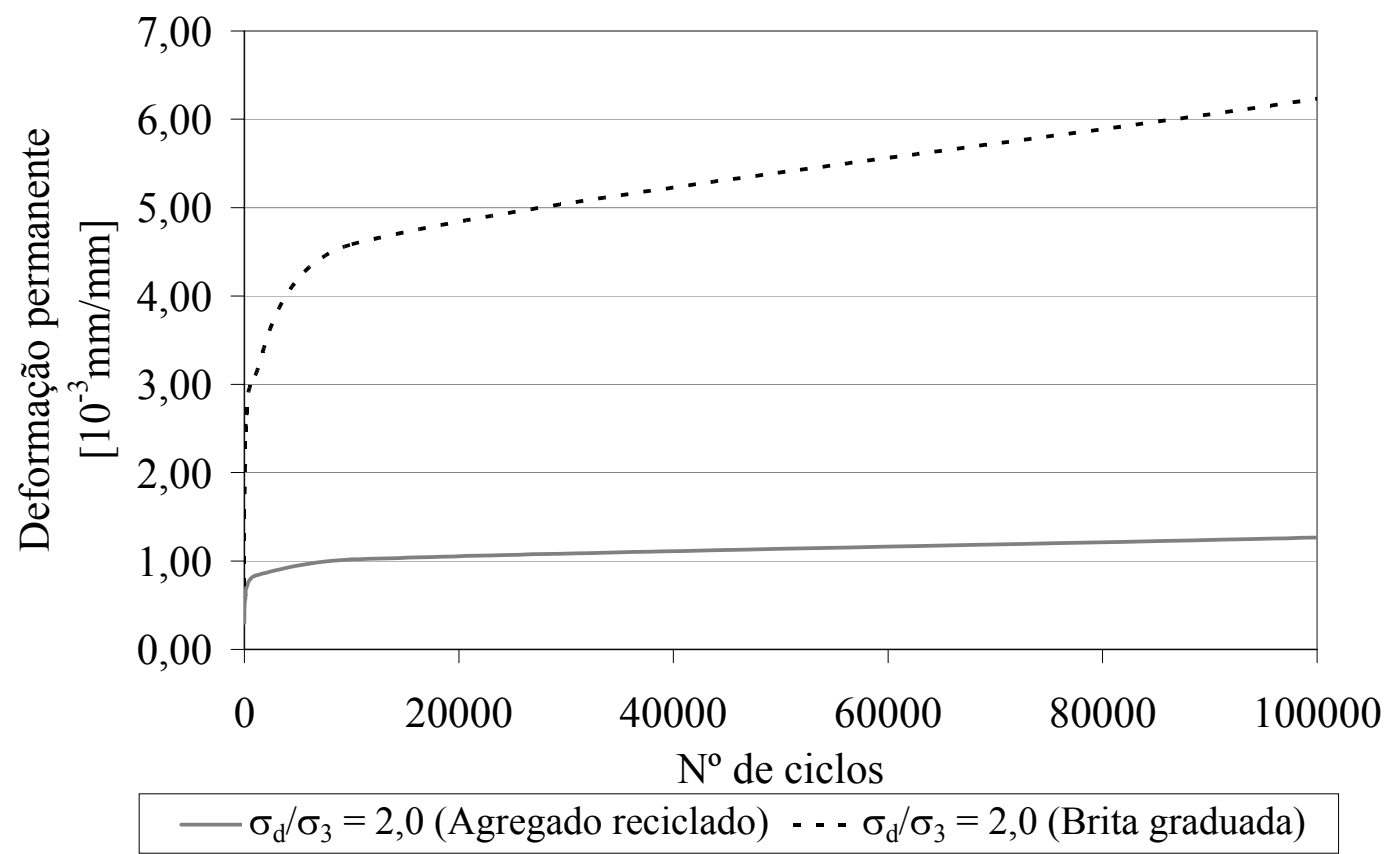

Figura 5.12: Deformação permanente obtida para o agregado reciclado de Santo André e para a brita com mesma granulometria compactados na energia modificada

Analisando o gráfico, pode-se concluir que para um mesmo nível de tensões, o agregado reciclado apresentou uma deformação permanente aos 100.000 ciclos muito inferior à brita graduada, de $1,27 \times 10^{-3} \mathrm{~mm} / \mathrm{mm}$ frente à $6,23 \times 10^{-3} \mathrm{~mm} / \mathrm{mm}$ deste último material. Apesar dos materiais terem a mesma granulometria, o agregado reciclado demonstra uma coesão maior, que influencia no comportamento do material quando submetido a uma tensão de confinamento pequena. Além disso, a superfície irregular dos grãos aumenta a abrasão no contato e propicia maior resistência ao cisalhamento nestas condições de tensão. Por estes resultados pode-se concluir que a brita graduada é um material que trabalha melhor quando bem confinado, devendo ter também uma graduação muito bem ajustada para garantir um maior entrosamento.

A Tabela 5.19 apresenta valores de deformações permanentes encontrados na bibliografia consultada, para diferentes tipos de materiais e níveis de tensões. 
Tabela 5.19: Deformações permanentes medidas por ensaios triaxiais de cargas repetidas para diferentes materiais de acordo com a literatura revisada

\begin{tabular}{|c|c|c|c|c|c|c|}
\hline Material & $\begin{array}{c}\sigma_{\mathrm{d}} \\
{[\mathrm{kPa}]}\end{array}$ & $\begin{array}{c}\sigma_{3} \\
{[\mathrm{kPa}]}\end{array}$ & $\begin{array}{c}\text { Relação } \\
\sigma_{d} / \sigma_{3}\end{array}$ & $\begin{array}{c}\mathcal{E}_{\mathrm{p}} \\
{\left[10^{-3} \mathrm{~mm} / \mathrm{mm}\right]}\end{array}$ & $\mathrm{N}$ & Autor \\
\hline $\begin{array}{c}\text { Agregado } \\
\text { reciclado } \\
\text { (energia } \\
\text { intermediária) }\end{array}$ & 300 & 50 & 6,0 & 3,98 & \multirow{6}{*}{100.000} & \multirow{6}{*}{$\begin{array}{c}\text { Esta } \\
\text { pesquisa }\end{array}$} \\
\hline \multirow{4}{*}{$\begin{array}{c}\text { Agregado } \\
\text { reciclado } \\
\text { (energia } \\
\text { modificada) }\end{array}$} & 100 & 50 & 2,0 & 1,27 & & \\
\hline & 200 & 50 & 4,0 & 2,65 & & \\
\hline & 300 & 50 & 6,0 & 3,60 & & \\
\hline & 500 & 75 & 6,7 & 5,25 & & \\
\hline $\begin{array}{c}\text { Brita } \\
\text { graduada }\end{array}$ & 100 & 50 & 2,0 & 6,23 & & \\
\hline Granodiorito & 300 & 75 & 4,0 & 1,45 & \multirow{2}{*}{80.000} & \multirow{2}{*}{$\begin{array}{l}\text { Lekarp et } \\
\text { al. (1996) }\end{array}$} \\
\hline $\begin{array}{l}\text { Resíduo de } \\
\text { ardósia }\end{array}$ & 300 & 75 & 4,0 & 18,0 & & \\
\hline Laterita ${ }^{(r)}$ & 112,5 & 75 & 1,5 & 1,31 & 125.000 & $\begin{array}{c}\text { Guimarães } \\
\text { (2001) }\end{array}$ \\
\hline \multirow{2}{*}{$\begin{array}{c}\text { Brita } \\
\text { graduada } \\
\text { simples } \\
\text { (Faixa A } \\
\text { DNER) }{ }^{(r)}\end{array}$} & 66 & 21 & 3,1 & 4,76 & \multirow{2}{*}{84.000} & \multirow{2}{*}{$\begin{array}{l}\text { Malysz } \\
(2004)\end{array}$} \\
\hline & 132 & 21 & 6,3 & 11,64 & & \\
\hline
\end{tabular}

Observando a Tabela 5.19 é possível verificar que na bibliografia são encontrados valores de deformação permanente bem variáveis. Aparentemente, os corpos-deprova de agregado reciclado aqui analisados não sofreram deformações permanente elevadas, quando comparados com o resíduo de ardósia de Lekarp et al. (1996) e com a brita graduada simples de Malysz (2004).

De acordo com a bibliografia consultada, é difícil determinar um valor de deformação máxima admissível para materiais granulares por meio de ensaios triaxiais com cargas repetidas. Malysz (2004) estabeleceu como critério de ruptura em seu estudo uma deformação permanente axial máxima de $20 \mathrm{~mm}$, correspondente 
a $10 \%$ da altura do seu corpo-de-prova. Neste trabalho, não se teve como objetivo estipular um limite de deformação permanente para agregados reciclados, mas sim analisar a resposta destes materiais, quando submetidos a carregamentos sucessivos durante um longo período.

Por meio dos resultados de deformação permanente obtidos nesta pesquisa, foram determinados modelos para prever a deformação permanente do agregado reciclado e da brita graduada. Foram utilizados os modelos propostos por Monismith et al. (1975) e Barksdale (1972), apresentados nas equações (12) e (13), respectivamente. Os resultados são apresentados nas Tabela 5.20 e na Tabela 5.21.

Tabela 5.20: Modelos obtidos com os ensaios de deformação permanente utilizando o modelo de Monismith et al.(1975)

\begin{tabular}{|c|c|c|c|}
\hline Material & $\begin{array}{c}\text { Energia de } \\
\text { compactação }\end{array}$ & $\begin{array}{c}\text { Relação } \\
\sigma_{\mathrm{d}} / \sigma_{3}\end{array}$ & $\begin{array}{c}\text { Modelo de Monismith et al. } \\
(1975) \\
\varepsilon_{\mathrm{p}}\left[10^{-3} \mathrm{~mm} / \mathrm{mm}\right]\end{array}$ \\
\hline \multirow{2}{*}{$\begin{array}{c}\text { Agregado } \\
\text { reciclado }\end{array}$} & Intermediária & 6,0 & $\begin{array}{c}\varepsilon_{\mathrm{p}}=1,1754 \mathrm{~N}^{0,1027} \\
\mathrm{R}^{2}=0,9736\end{array}$ \\
\cline { 3 - 4 } & Modificada & 2,0 & $\begin{array}{c}\varepsilon_{\mathrm{p}}=0,3451 \mathrm{~N}^{0,1147} \\
\mathrm{R}^{2}=0,9854\end{array}$ \\
\cline { 3 - 4 } & & 6,0 & $\begin{array}{c}\varepsilon_{\mathrm{p}}=0,8127 \mathrm{~N}^{0,1039} \\
\mathrm{R}^{2}=0,9500\end{array}$ \\
\cline { 3 - 4 } & & 6,7 & $\begin{array}{c}\varepsilon_{\mathrm{p}}=1,1215 \mathrm{~N}^{0,1024} \\
\mathrm{R}^{2}=0,9828\end{array}$ \\
\hline $\begin{array}{c}\text { Brita } \\
\text { graduada }\end{array}$ & Modificada & 2,0 & $\begin{array}{c}\varepsilon_{\mathrm{p}}=0,9271 \mathrm{~N}^{0,1468} \\
\mathrm{R}^{2}=0,9824\end{array}$ \\
\hline $\begin{array}{c}\varepsilon_{\mathrm{p}}=0,9602 \mathrm{~N}^{0,1625} \\
\mathrm{R}^{2}=0,9746\end{array}$ \\
\hline
\end{tabular}


Tabela 5.21: Modelos obtidos com os ensaios de deformação permanente utilizando o modelo de Barksdale (1972)

\begin{tabular}{|c|c|c|c|}
\hline Material & $\begin{array}{c}\text { Energia de } \\
\text { compactação }\end{array}$ & $\begin{array}{c}\text { Relação } \\
\sigma_{\mathrm{d}} / \sigma_{3}\end{array}$ & $\begin{array}{c}\text { Modelo de Barksdale } \\
\qquad(1972) \\
\varepsilon_{\mathrm{p}}\left[10^{-3} \mathrm{~mm} / \mathrm{mm}\right]\end{array}$ \\
\hline \multirow{5}{*}{$\begin{array}{l}\text { Agregado } \\
\text { reciclado }\end{array}$} & Intermediária & 6,0 & $\begin{array}{c}\varepsilon_{\mathrm{p}}=0,8003+0,6017 \log \mathrm{N} \\
\mathrm{R}^{2}=0,9199\end{array}$ \\
\hline & \multirow{4}{*}{ Modificada } & 2,0 & $\begin{array}{c}\varepsilon_{\mathrm{p}}=0,2340+0,2069 \log \mathrm{N} \\
\mathrm{R}^{2}=0,9878\end{array}$ \\
\hline & & 4,0 & $\begin{array}{c}\varepsilon_{\mathrm{p}}=0,6095+0,4023 \log \mathrm{N} \\
\mathrm{R}^{2}=0,9410\end{array}$ \\
\hline & & 6,0 & $\begin{array}{c}\varepsilon_{\mathrm{p}}=0,8773+0,5412 \log N \\
\mathrm{R}^{2}=0,9879\end{array}$ \\
\hline & & 6,7 & $\begin{array}{c}\varepsilon_{\mathrm{p}}=0,0291+0,9926 \log \mathrm{N} \\
\mathrm{R}^{2}=0,8987\end{array}$ \\
\hline $\begin{array}{l}\text { Brita } \\
\text { graduada }\end{array}$ & Modificada & 2,0 & $\begin{array}{c}\varepsilon_{\mathrm{p}}=0,0744+1,1809 \log \mathrm{N} \\
\mathrm{R}^{2}=0,9619\end{array}$ \\
\hline
\end{tabular}

De acordo com a bibliografia consultada, o modelo logarítmico de Barksdale (1972) apresenta normalmente resultados inferiores aos do modelo exponencial de Monismith et al. (1975). Para efeito comparativo, a Tabela 5.22 apresenta aos 100.000 ciclos os valores de deformação permanente obtidos pelos ensaios e pelos modelos.

Tabela 5.22: Deformações permanentes obtidas nos ensaios e pelos modelos de previsão de Monismith et al.(1975) e Barksdale (1972) para 100.000 ciclos

\begin{tabular}{|c|c|c|c|c|c|}
\hline \multirow[b]{2}{*}{ Material } & \multirow[b]{2}{*}{ Energia } & \multirow{2}{*}{$\begin{array}{c}\text { Relação } \\
\sigma_{\mathrm{d}} / \sigma_{3}\end{array}$} & \multicolumn{3}{|c|}{$\begin{array}{c}\text { Deformação permanente } \\
{\left[10^{-3} \mathrm{~mm} / \mathrm{mm}\right]}\end{array}$} \\
\hline & & & $\begin{array}{c}\varepsilon_{\mathrm{p}} \\
\text { do ensaio }\end{array}$ & $\begin{array}{c}\varepsilon_{\mathrm{p}} \\
\text { Monismith } \\
\text { et al.(1975) }\end{array}$ & $\begin{array}{c}\varepsilon_{\mathrm{p}} \\
\text { Barksdale } \\
(1972)\end{array}$ \\
\hline \multirow{5}{*}{$\begin{array}{l}\text { Agregado } \\
\text { reciclado }\end{array}$} & Intermediária & 6,0 & 3,98 & 3,83 & 3,81 \\
\hline & \multirow{4}{*}{ Modificada } & 2,0 & 1,27 & 1,29 & 1,27 \\
\hline & & 4,0 & 2,65 & 2,69 & 2,62 \\
\hline & & 6,0 & 3,60 & 3,64 & 3,58 \\
\hline & & 6,7 & 5,25 & 5,02 & 4,99 \\
\hline $\begin{array}{c}\text { Brita } \\
\text { graduada }\end{array}$ & Modificada & 2,0 & 6,23 & 6,23 & 5,98 \\
\hline
\end{tabular}


Analisando a Tabela 5.22 verifica-se que realmente o modelo de Barksdale (1972) apresentou resultados inferiores às deformações permanentes obtidas com o modelo de Monismith et al. (1975). Comparando com os resultados dos ensaios, observa-se que as deformações permanentes calculadas pelos modelos são próximas às deformações permanentes ocorridas.

Para concluir a análise da deformação permanente, é apresentado na Tabela 5.23 valores de deformação permanente verificadas na literatura consultada para agregados reciclados aos 100.000 ciclos, comparando com os resultados obtidos pelos modelos de Monismith et al. (1975) e de Barksdale (1972).

Tabela 5.23: Deformações permanentes verificadas na literatura para agregados reciclados utilizando os modelos de previsão de Monismith et al.(1975) e Barksdale (1972) para 100.000 ciclos

\begin{tabular}{|c|c|c|c|c|c|}
\hline \multirow{2}{*}{$\begin{array}{c}\text { Composição } \\
\text { do agregado } \\
\text { reciclado }\end{array}$} & \multirow{2}{*}{$\begin{array}{c}\text { Relação } \\
\sigma_{\mathrm{d}} / \sigma_{3}\end{array}$} & \multicolumn{3}{|c|}{$\begin{array}{l}\text { Deformação permanente } \\
\qquad\left[10^{-3} \mathrm{~mm} / \mathrm{mm}\right]\end{array}$} & \multirow{2}{*}{ Autor } \\
\hline & & $\begin{array}{c}\varepsilon_{\mathrm{p}} \\
\text { do ensaio }\end{array}$ & $\begin{array}{l}\varepsilon_{\mathrm{p}} \\
\text { Monismith } \\
\text { et al.(1975) }\end{array}$ & $\begin{array}{c}\varepsilon_{\mathrm{p}} \\
\text { Barksdale } \\
(1972)\end{array}$ & \\
\hline \multirow{2}{*}{ Misto } & 2,0 & 1,27 & 1,29 & 1,27 & \multirow{2}{*}{$\begin{array}{c}\text { Esta } \\
\text { pesquisa }\end{array}$} \\
\hline & 4,0 & 2,65 & 2,69 & 2,62 & \\
\hline Misto $^{(\mathrm{s})}$ & 3,0 & 5,10 & 5,28 & - & $\begin{array}{c}\text { Fernandes } \\
\quad(2004)\end{array}$ \\
\hline Concreto $^{(t)}$ & 3,0 & 3,86 & 5,37 & 4,33 & $\begin{array}{l}\text { Bennert et } \\
\text { al. (2000) }\end{array}$ \\
\hline
\end{tabular}

Pela Tabela 5.23 verifica-se que os modelos obtidos neste trabalho apresentaram para níveis de tensões baixos valores mais próximos do observado nos ensaios em comparação ao estudo de Bennert et al. (2000). Fernandes (2004) verificou para seu agregado reciclado uma boa previsão do comportamento de laboratório pelo modelo de Monismith et al. (1975). Além disso, para uma relação $\sigma_{d} / \sigma_{3}$ mais elevada, o agregado reciclado de Santo André apresentou deformações permanentes inferiores 
ao observado por Bennert et al. (2000) e Fernandes (2004). Este fato pode ser explicado em função da graduação do material, já que o agregado reciclado estudado neste trabalho apresenta $28 \%$ de material passante na peneira $0,42 \mathrm{~mm}$ após a compactação na energia modificada. Esta quantidade de partículas finas implica em uma maior da coesão no corpo-de-prova e, para tensões de confinamento baixas, em um aumento da resistência à deformação permanente.

\subsubsection{Teoria do shakedown}

Os mesmos corpos-de-prova analisados na deformação permanente são analisados sob o ponto de vista da teoria do shakedown. Teve-se o objetivo de verificar se a deformação permanente sofrida pelo corpo-de-prova de agregado reciclado com a repetição de cargas poderia conduzi-lo à ruptura ou mostraria tendência à estabilização (GUIMARÃES, 2001).

A análise utilizando a teoria do shakedown foi desenvolvida de forma similar ao estudo da deformação permanente, entretanto são verificados os resultados dos corpos-de-prova levados até os 180.000 ciclos.

A Figura 5.13 apresenta a análise da influência da energia de compactação no índice de deformação permanente vertical (razão entre a deformação permanente e o número de repetições acumuladas do carregamento, em $\left[10^{-3} / \mathrm{n}^{\mathrm{o}}\right.$ de repetições]) do agregado reciclado de Santo André. Esta representação permite que o comportamento do material seja analisado à luz da teoria do shakedown, segundo Werkmeister et al. (2001) classificando-o em um dos três limites apresentados no item 4.4.3.2 (limite A, B ou C). 


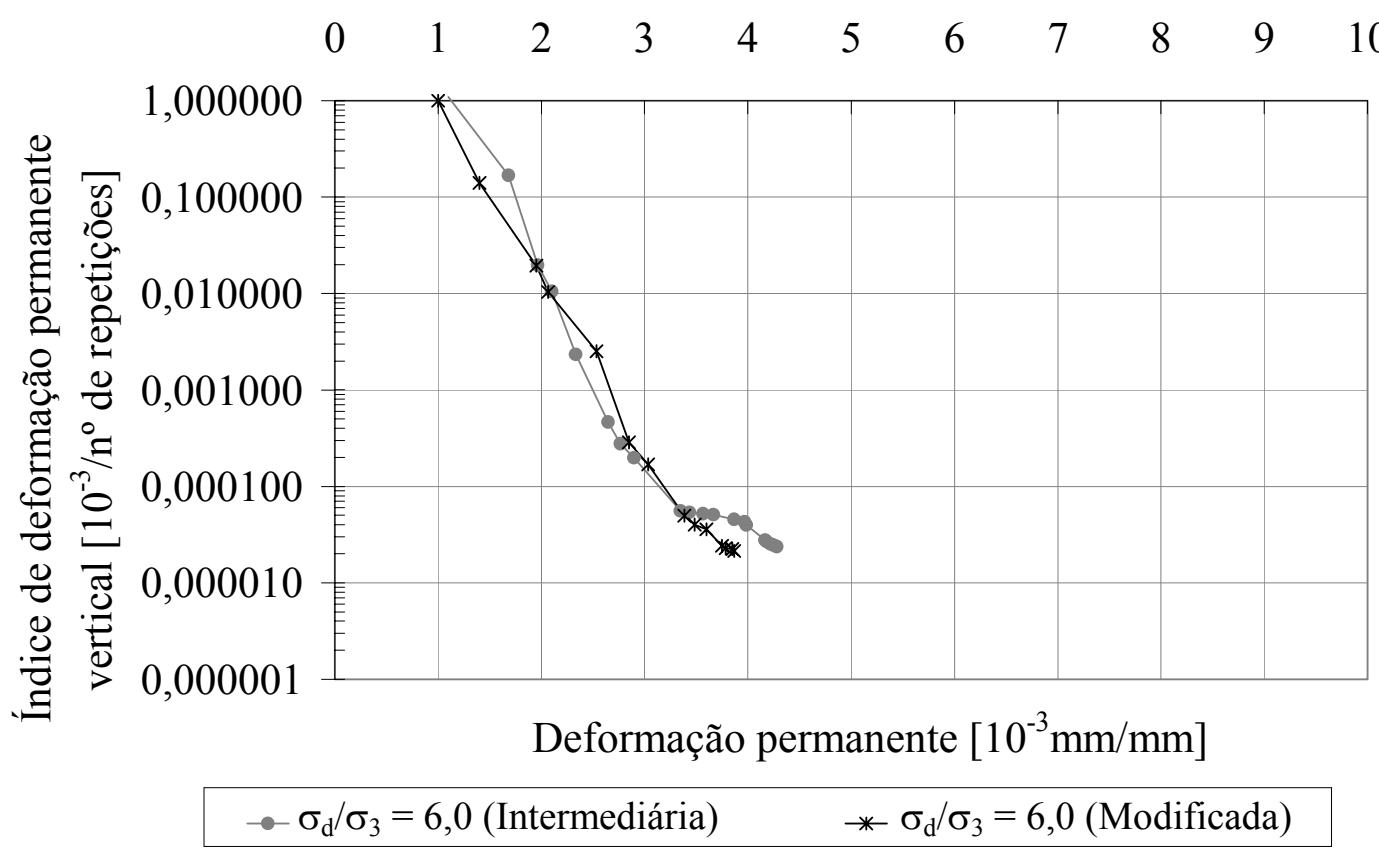

Figura 5.13: Análise do índice de deformação permanente para o agregado reciclado de Santo André compactado na energia intermediária e modificada

De acordo com o gráfico apresentado, pode-se verificar que a energia de compactação afeta o desempenho do agregado reciclado. $\mathrm{O}$ material compactado na energia intermediária apresentou uma deformação permanente superior ao do material compactado na energia modificada. Analisando o comportamento do agregado reciclado, conclui-se que sob este nível de tensões, o material tem uma resposta intermediária do shakedown, estando no limite B. Durante os primeiros ciclos de carregamento, a deformação permanente é elevada, mas decresceu com as sucessivas aplicações de carga, até apresentar um aumento constante. Observa-se que para baixos índices de deformação permanente vertical, o material compactado na energia modificada mostra melhor tendência à estabilização que aquele compactado na energia intermediária.

A Figura 5.14 ilustra o índice de deformação permanente do agregado reciclado de Santo André compactado na energia modificada, submetido a quatro níveis de tensões. 


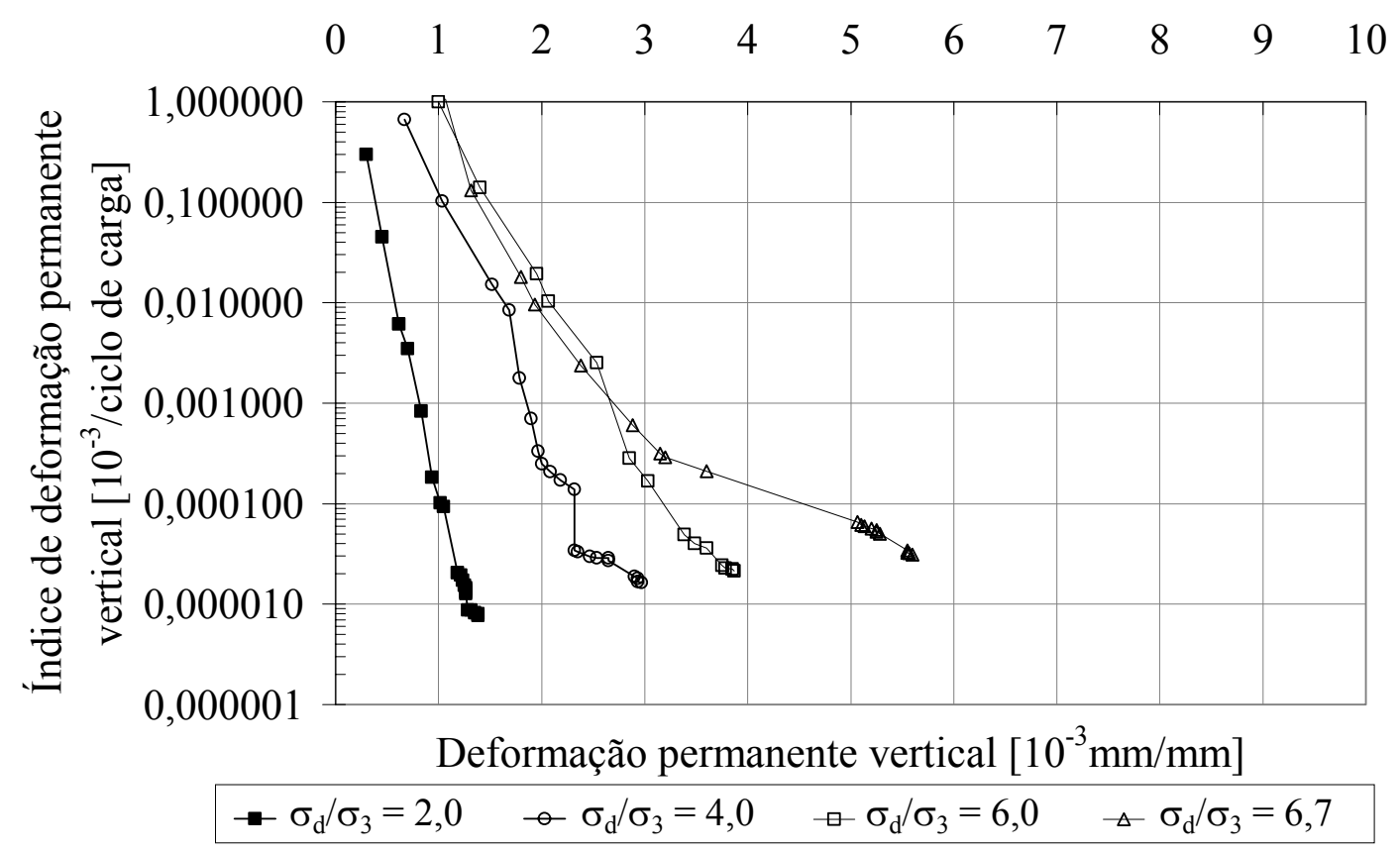

Figura 5.14: Análise do índice de deformação permanente para o agregado reciclado de Santo André compactado na energia modificada submetido a diferentes níveis de tensões

Analisando a Figura 5.14, verifica-se que o nível de tensões influencia na resistência do agregado reciclado à deformação permanente. O material submetido ao nível de tensões menor $\left(\sigma_{\mathrm{d}} / \sigma_{3}=2,0\right)$ sofreu deformações plásticas no início do carregamento. Contudo, após o período de pós-compactação do material, ocorreram praticamente apenas deformações resilientes. O comportamento do material passou a ser elástico, classificando-o como limite A do shakedown.

$\mathrm{O}$ agregado reciclado submetido a $\sigma_{\mathrm{d}} / \sigma_{3}=4,0$ e 6,0 , tiveram uma resposta intermediária à luz da teoria do shakedown, estando no limite B. Durante os primeiros ciclos de carregamento a deformação permanente é elevada, mas diminuiu com as sucessivas aplicações de carga, até apresentar um aumento praticamente constante.

Para o nível de tensões $\sigma_{\mathrm{d}} / \sigma_{3}=6,7$, o material sofreu uma grande deformação inicial e com o tempo continuou apresentando um constante e elevado aumento das deformações permanentes. É difícil classificar o material em um limite do shakedown, pois seria necessário conduzir o ensaio a um número maior de ciclos, 
verificando a tendência à estabilização ou se ocorreria a ruptura. Relações altas de $\sigma_{\mathrm{d}} / \sigma_{3}$ podem levar o material à ruptura por diferença de tensões, excedendo à resistência ao cisalhamento. A Figura 5.15 ilustra mais claramente quando o material tende a estabilizar, como no caso $\sigma_{\mathrm{d}} / \sigma_{3}=2,0$, e quando a deformação cresce de forma constantes, como no caso $\sigma_{\mathrm{d}} / \sigma_{3}=6,7$.

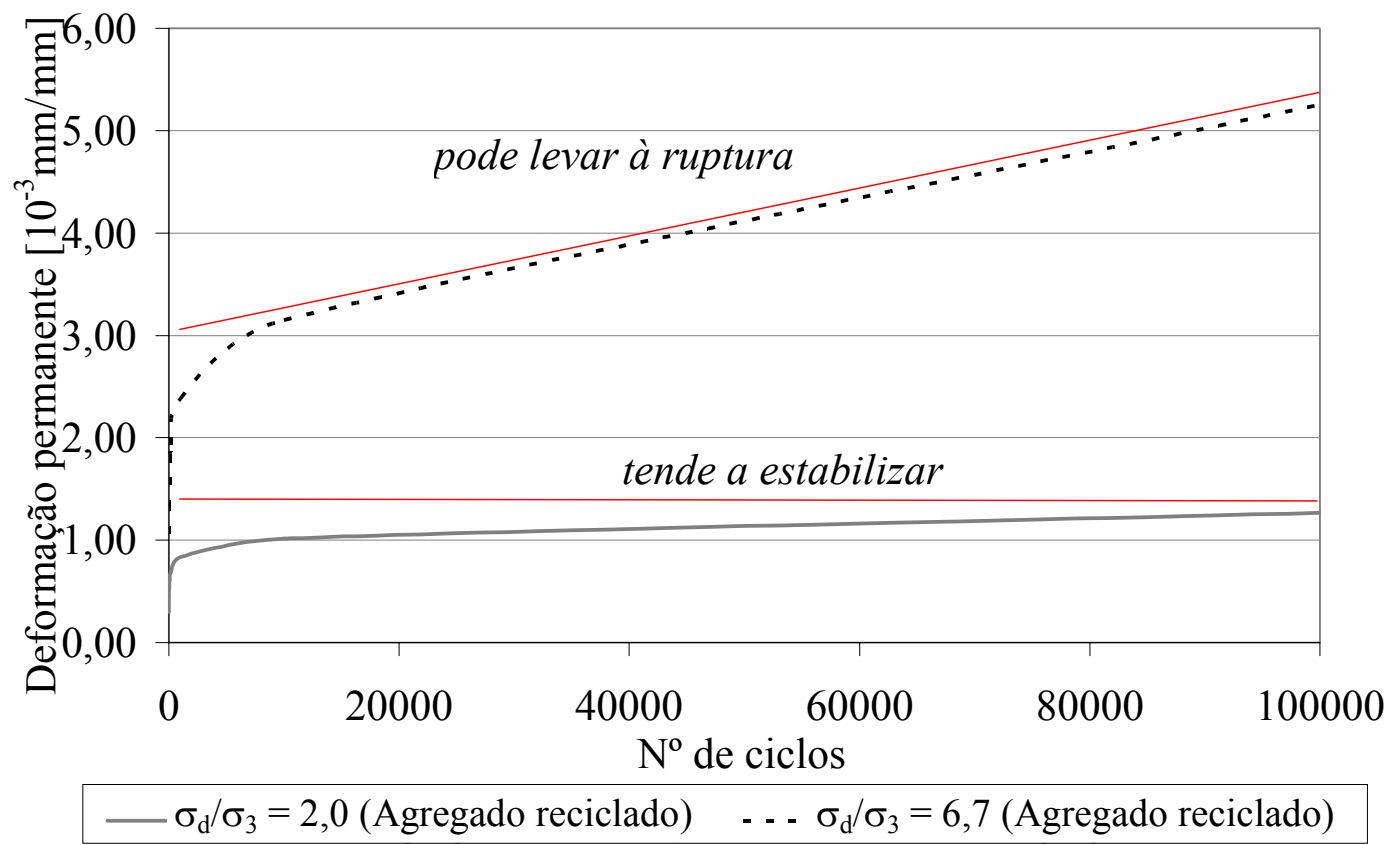

Figura 5.15: Deformação permanente obtida para o agregado reciclado de Santo André em nível de tensão baixo e alto

\subsection{Controle tecnológico}

Os resultados do controle tecnológico são apresentados e analisados de acordo com os relatórios de acompanhamento da obra do sistema viário da USP Leste e com os levantamentos em campo utilizando o Dynamic Cone Penetrometer e o Falling Weight Deflectometer.

Neste trabalho são discutidos os resultados do controle tecnológico referentes aos 1.020 metros de pista do sistema viário da USP Leste aqui analisados. 


\subsubsection{Controle tecnológico dos materiais}

Em função do recomendado pela NBR 15115 (ABNT, 2004), neste trabalho dividiuse a análise do controle tecnológico dos materiais em quatro partes: granulometria, forma dos grãos, compactação e índice de suporte Califórnia.

$\mathrm{Na}$ extensão de 1.020 metros aqui analisada, foram coletadas amostras de agregados reciclados de duas proveniências: Santo André e São Bernardo do Campo.

\subsubsection{Granulometria}

Os ensaios de granulometria foram realizados de acordo com a metodologia prescrita na NBR 7181 (ABNT, 1984), utilizada para solos. O material não foi lavado na peneira $0,075 \mathrm{~mm}$ e foram utilizadas apenas seis peneiras: $50 ; 9,5 ; 4,8 ; 2,0 ; 0,42 \mathrm{e}$ $0,075 \mathrm{~mm}$.

A NBR 15115 (ABNT, 2004) prescreve que devem ser realizadas no mínimo três determinações de granulometria a cada lote equivalente a $700 \mathrm{~m}^{2}$ de camada acabada. Como o pavimento da USP Leste possui uma largura de aproximadamente sete metros, para a extensão de 1.020 metros de pavimento aqui analisada deveriam ser realizadas, aproximadamente, 10 ensaios de granulometria. De acordo com os relatórios de acompanhamento, para este trecho em estudo foram feitos oito ensaios de granulometria.

Foram analisadas seis amostras provenientes da usina recicladora localizada em Santo André e duas amostras da usina recicladora situada em São Bernardo do Campo. A Figura 5.16 apresenta as curvas granulométricas dos diferentes lotes de agregados reciclados analisados durante o controle tecnológico dos materiais e a curva granulométrica do agregado reciclado de Santo André estudado em laboratório. 


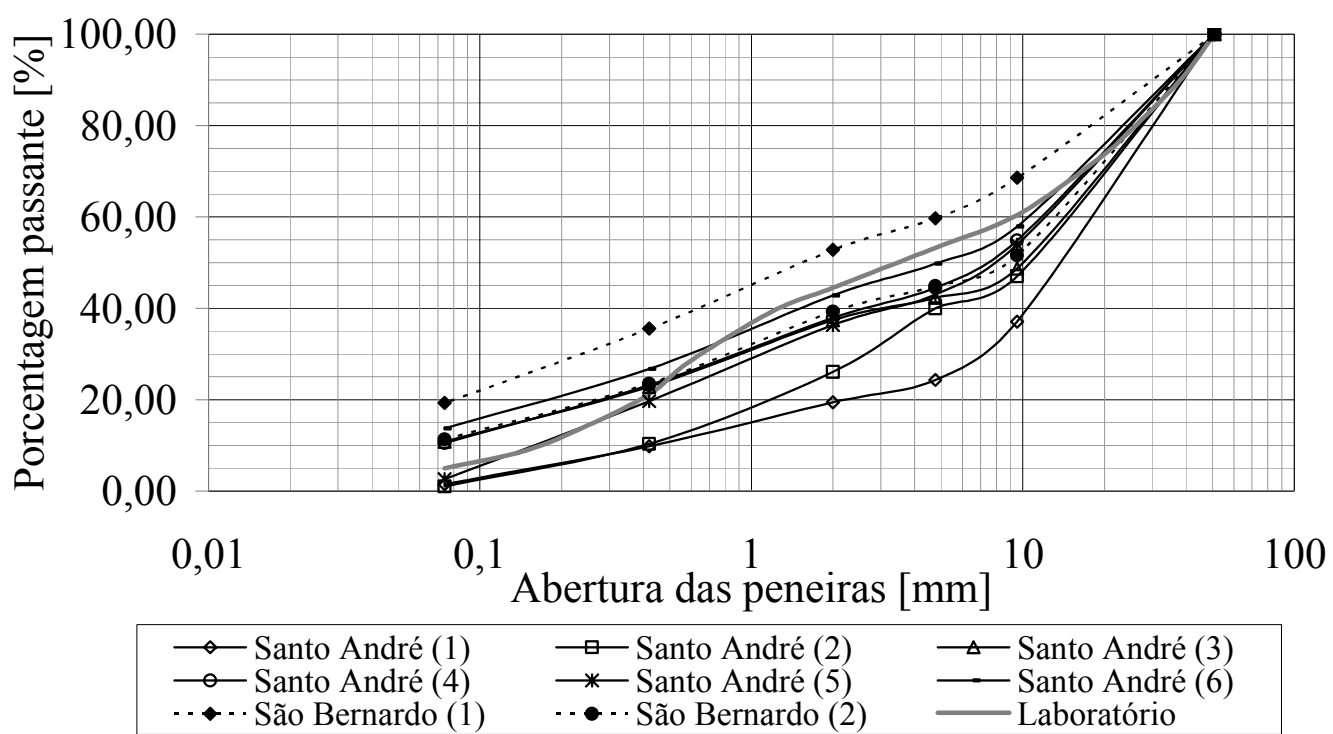

Figura 5.16: Granulometrias dos agregados reciclados empregados no sistema viário da USP Leste

Pelas curvas granulométricas apresentadas é possível verificar a grande variabilidade granulométrica dos agregados reciclados. Em função desta variabilidade, é importante ressaltar que o número de ensaios previsto na NBR 15115 (ABNT, 2004) deve ser respeitado. Caso contrário torna-se difícil o controle da homogeneidade do material.

A Tabela 5.24 apresenta a dimensão característica máxima dos grãos, porcentagem passante na peneira $0,42 \mathrm{~mm}$, coeficiente de uniformidade $\left(\mathrm{C}_{\mathrm{u}}\right)$ e coeficiente de curvatura $\left(\mathrm{C}_{\mathrm{c}}\right)$ determinados para as curvas granulométricas apresentadas. 
Tabela 5.24: Dimensão característica máxima dos grãos, porcentagem que passa na peneira $0,42 \mathrm{~mm}$, coeficiente de uniformidade e coeficiente de curvatura dos agregados reciclados empregados no sistema viário da USP Leste

\begin{tabular}{|c|c|c|c|c|}
\hline Autor & $\begin{array}{c}\text { Dimensão } \\
\text { característica } \\
\text { máxima dos grãos } \\
{[\mathrm{mm}]}\end{array}$ & $\begin{array}{c}\text { Porcentagem que } \\
\text { passa na peneira } \\
0,42 \mathrm{~mm}[\%]\end{array}$ & $\mathrm{C}_{\mathrm{u}}$ & $\mathrm{C}_{\mathrm{c}}$ \\
\hline $\begin{array}{c}\text { NBR } 15115 \\
(\text { ABNT, 2004) }\end{array}$ & 63,5 & $10 \leq a \leq 40$ & $\geq 10$ & $\begin{array}{c}\text { não } \\
\text { consta }\end{array}$ \\
\hline $\begin{array}{c}\text { PMSP/SP } \\
\text { ETS-001 } \\
(\text { PMSP, 2003) }\end{array}$ & 50,0 & $10 \leq a \leq 30$ & $\geq 10$ & $1 \leq \mathrm{a} \leq 3$ \\
\hline $\begin{array}{l}\text { Esta pesquisa } \\
\text { (material de } \\
\text { laboratório) }\end{array}$ & 50,0 & 21,2 & 53 & 0,30 \\
\hline Santo André (1) & 50,0 & 9,8 & 26 & 11,23 \\
\hline Santo André (2) & 50,0 & 10,3 & 25 & 1,50 \\
\hline Santo André (3) & 50,0 & 22,8 & 148 & 1,14 \\
\hline Santo André (4) & 50,0 & 23,2 & 144 & 1,41 \\
\hline Santo André (5) & 50,0 & 19,7 & 60 & 0,98 \\
\hline Santo André (6) & 50,0 & 26,7 & 250 & 0,72 \\
\hline São Bernardo (1) & 50,0 & 35,6 & 167 & 1,00 \\
\hline São Bernardo (2) & 50,0 & 23,5 & 145 & 0,35 \\
\hline
\end{tabular}

De acordo com a Tabela 5.24, todas as amostras ensaiadas atenderam ao projeto de pavimentação do sistema viário da USP Leste quanto à dimensão característica máxima dos grãos, igual a $50 \mathrm{~mm}$. Em relação à porcentagem passante na peneira 0,42mm, apenas a amostras Santo André (1) não atendeu, apresentando menos de $10 \%$. Todas as amostras também apresentaram $\mathrm{C}_{\mathrm{u}}$ maior que 10 , caracterizando um material não uniforme conforme a NBR 15115 (ABNT, 2004). Os $\mathrm{C}_{\mathrm{c}}$ obtidos indicaram que quatro amostras não são consideradas bem graduadas, pois se encontram fora dos limites prescritos pela PMSP/SP ETS-001 (PMSP, 2003).

Além da análise granulométrica prevista no controle tecnológico, a empresa fiscalizadora da obra coletou em dois pontos amostras de agregado reciclado após a compactação da camada. Teve-se o objetivo de avaliar possíveis modificações na granulometria do material depois do processo de compactação. 
O ensaio de granulometria foi feito sem lavagem e utilizando apenas as seis peneiras previstas na NBR 7181 (ABNT, 1984) mencionadas. As duas amostras ensaiadas são provenientes da usina recicladora localizada em Santo André, correspondente às amostras Santo André (1) e Santo André (2). O material foi retirado da camada de sub-base, nos pontos correspondentes às distâncias de $0,190 \mathrm{~km}$ e $0,230 \mathrm{~km}$, respectivamente. Destaca-se que a energia de compactação prevista em projeto é de no mínimo $95 \%$ da modificada. As curvas granulométricas obtidas são apresentadas na Figura 5.17.

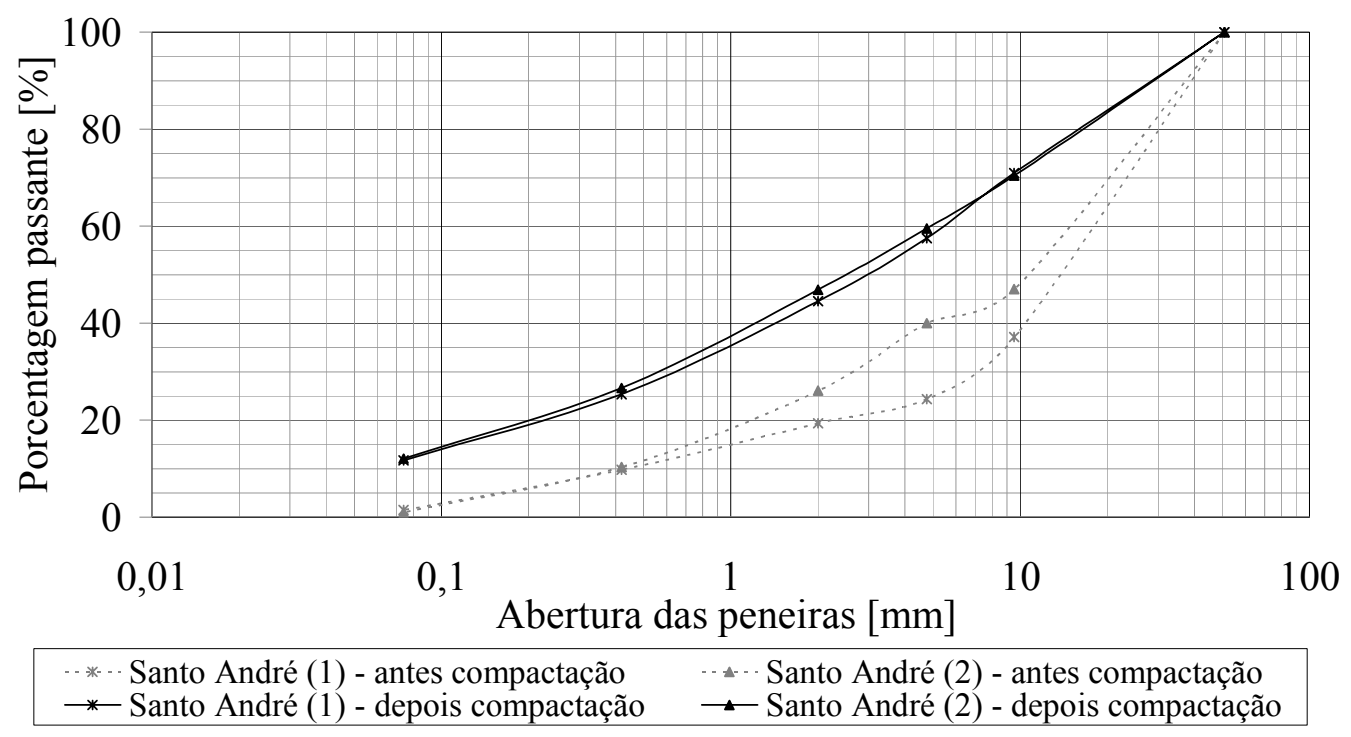

Figura 5.17: Granulometria dos agregados reciclados empregados no sistema viário da USP Leste depois da compactação da camada de sub-base

Pela Figura 5.16 apresentada anteriormente, amostras de agregado reciclado de mesma origem apresentavam granulometrias iniciais distintas. Contudo, analisando a Figura 5.17, é possível verificar que depois da compactação, as amostras tornam-se mais similares granulometricamente. Este efeito proporcionado pela compactação é altamente benéfico, pois homogeneíza materiais. Isto reforça a importância da energia de compactação elevada, obtendo-se a maior quebra dos grãos possível durante a execução, para que durante a vida útil do pavimento este problema seja minimizado, evitando possíveis afundamentos ou mesmo rupturas indesejadas. 
As amostras de agregado reciclado analisadas depois da compactação em campo atendem a norma NBR 15115 (ABNT, 2004) referente à porcentagem passante na peneira $0,42 \mathrm{~mm}$ e ao $\mathrm{C}_{\mathrm{u}}$. Quanto ao $\mathrm{C}_{\mathrm{c}}$, o material não pode ser considerado bem graduado, pois os valores continuam para ambas as amostras abaixo de 1. A Tabela 5.25 apresenta os resultados obtidos.

Tabela 5.25: Resultados de porcentagem passante na peneira $0,42 \mathrm{~mm} \mathrm{e} \mathrm{C}_{\mathrm{u}}$ dos agregados reciclados empregados no sistema viário da USP Leste

\begin{tabular}{|c|c|c|c|c|}
\hline Amostra & $\begin{array}{c}\text { Dimensão } \\
\text { característica } \\
\text { máxima dos } \\
\text { grãos [mm] }\end{array}$ & $\begin{array}{c}\text { Porcentagem que } \\
\text { passa na peneira } \\
0,42 \mathrm{~mm}[\%]\end{array}$ & $\mathrm{C}_{\mathrm{u}}$ & $\mathrm{C}_{\mathrm{c}}$ \\
\hline $\begin{array}{c}\text { NBR 15115 } \\
\text { (ABNT, 2004) }\end{array}$ & 63,5 & $10 \leq \mathrm{a} \leq 40$ & $\geq 10$ & $\begin{array}{c}\text { não } \\
\text { consta }\end{array}$ \\
\hline $\begin{array}{c}\text { PMSP/SP } \\
\text { ETS-001 } \\
\text { (PMSP, 2003) }\end{array}$ & 50,0 & $10 \leq \mathrm{a} \leq 30$ & $\geq 10$ & $1 \leq \mathrm{a} \leq 3$ \\
\hline $\begin{array}{c}\text { Santo André (1) - } \\
\text { depois compactação } \\
\text { 0,190km }\end{array}$ & 50,0 & 25,3 & 79 & 0,93 \\
\hline $\begin{array}{c}\text { Santo André (2) - } \\
\text { depois compactação } \\
\text { 0,230km }\end{array}$ & 50,0 & 26,6 & 71 & 0,86 \\
\hline
\end{tabular}

\subsubsection{Forma dos grãos}

De acordo com a NBR 15115 (ABNT, 2004), devem ser realizadas no mínimo três determinações da forma dos grãos a cada lote equivalente a $700 \mathrm{~m}^{2}$ de camada acabada. Como o pavimento da USP Leste possui uma largura de aproximadamente sete metros, para a extensão de 1.020 metros de pavimento aqui analisada, deveriam ser realizadas aproximadamente 10 ensaios para análise da forma. De acordo com os relatórios de acompanhamento, para este trecho em estudo foi feito apenas um ensaio de determinação da forma.

A amostra coletada para determinação da forma é proveniente da usina recicladora de São Bernardo do Campo. Não foi especificado pela empresa fiscalizadora qual método de ensaio foi adotado. 
De acordo com o relatório de acompanhamento, para o agregado reciclado analisado observou-se a presença de $24,2 \%$ de grãos lamelares. Este resultado atende a NBR 15115 (ABNT, 2004) que recomenda no máximo 30\% de grãos lamelares.

Contudo, em conseqüência da falta de repetições de ensaios, não se pode afirmar que a forma do agregado reciclado utilizado no pavimento do sistema viário da USP Leste foi controlada.

\subsubsection{Compactação}

Com relação à compactação, a NBR 15115 (ABNT, 2004) prescreve que devem ser realizadas no mínimo três determinações, a cada lote equivalente a $2.000 \mathrm{~m}^{2}$ de camada acabada. No caso da pista de 1.020 metros aqui estudada, deveriam ser realizados quatro ensaios de compactação. Segundo os relatórios de acompanhamento da obra, foram realizados seis ensaios.

A compactação foi realizada conforme a NBR 7182 (ABNT, 1986), na energia intermediária, utilizando o cilindro metálico grande. O relatório não apresentou detalhes tanto sobre as curvas de compactação obtidas, como sobre a eventual substituição de materiais retidos na peneira 19,0mm. Também não são informados os locais de coleta e aplicação das amostras. Os agregados reciclados submetidos aos ensaios são provenientes de Santo André e de São Bernardo do Campo. A Tabela 5.26 apresenta os resultados obtidos com os ensaios de compactação no controle tecnológico dos materiais. 
Tabela 5.26: Resultados dos ensaios de compactação dos agregados reciclados empregados no sistema viário da USP Leste

\begin{tabular}{|c|c|c|c|}
\hline Amostra & Energia & Umidade ótima [\%] & $\begin{array}{c}\text { Peso específico } \\
\text { aparente seco } \\
\left.\text { máximo [kN/m }{ }^{3}\right]\end{array}$ \\
\hline $\begin{array}{c}\text { Esta pesquisa } \\
\text { (material de } \\
\text { laboratório) }\end{array}$ & intermediária & 14,6 & 17,6 \\
\cline { 2 - 4 } & modificada & 13,5 & 18,2 \\
\hline Santo André (1) & intermediária & 13,4 & 17,7 \\
\hline Santo André (2) & intermediária & 13,5 & 16,8 \\
\hline Santo André (3) & intermediária & 15,3 & 17,7 \\
\hline Santo André (4) & intermediária & 16,3 & 17,6 \\
\hline São Bernardo (1) & intermediária & 15,5 & 18,1 \\
\hline São Bernardo (2) & intermediária & 15,3 & 18,8 \\
\hline
\end{tabular}

Pelos resultados apresentados, é possível observar uma pequena variação entre os valores de umidade ótima e peso específico aparente seco máximo dos agregados reciclados. Os resultados de campo foram bastante similares aos do material estudado em laboratório.

\subsubsection{4 Índice de suporte Califórnia}

De forma análoga à compactação, a NBR 15115 (ABNT, 2004) recomenda que sejam realizados ensaios de índice de suporte Califórnia e de expansão a cada lote equivalente a $2.000 \mathrm{~m}^{2}$ de camada acabada, com no mínimo três determinações. Para os 1.020 metros deveriam ser realizados quatro ensaios. No entanto, os relatórios de acompanhamento da obra indicaram que foram executados seis.

As amostras submetidas aos ensaios de índice de suporte Califórnia e de expansão foram as mesmas do ensaio de compactação apresentadas no item 5.4.1.3. Os ensaios foram realizados conforme a NBR 9895 (ABNT, 1987) e os resultados são apresentados na Tabela 5.27. 
Tabela 5.27: Resultados de índice de suporte Califórnia e expansão dos agregados reciclados empregados no sistema viário da USP Leste

\begin{tabular}{|c|c|c|c|}
\hline Amostra & Energia & ISC [\%] & Expansão [\%] \\
\hline $\begin{array}{c}\text { Esta pesquisa } \\
\text { (material de } \\
\text { laboratório) }\end{array}$ & intermediária & $73^{(\mathrm{u})}$ & 0 \\
\cline { 2 - 4 } & modificada & $117^{(\mathrm{u})}$ & 0 \\
\hline Santo André (1) & intermediária & 84 & 0 \\
\hline Santo André (2) & intermediária & 53 & 0 \\
\hline Santo André (3) & intermediária & 59 & 0 \\
\hline Santo André (4) & intermediária & 63 & 0 \\
\hline São Bernardo (1) & intermediária & 49 & 0 \\
\hline São Bernardo (2) & intermediária & 70 & 0 \\
\hline
\end{tabular}

(u) Valores médios

Analisando a Tabela 5.27, é possível concluir que os agregados reciclados apresentam valores de ISC variáveis. As amostras Santo André (2), Santo André (3) e São Bernardo (1) não possuem índice de suporte Califórnia suficiente para serem utilizadas na camada de base, de acordo com a NBR 15115 (ABNT, 2004) que recomenda no mínimo ISC igual a $60 \%$. Contudo, estes materiais podem ser empregados em sub-bases, pois possuem ISC maior que 20\%. Além disso, destaca-se o fato de que os agregados reciclados não apresentaram expansão.

Observou-se na obra a presença expressiva de solo na mistura São Bernardo (1), com mais de $35 \%$ passante na peneira $0,42 \mathrm{~mm}$. Este fator fez com que o ISC tivesse seu valor reduzido. A prática que possa vir ser estabelecida de mistura de solo deve ser evitada nas usinas recicladoras, pois estes materiais não são selecionados e podem prejudicar sobremaneira os resultados. A mistura de agregados reciclados e solo pode ser realizada, segundo a técnica do solo-brita, empregando nestes casos solos exclusivamente lateríticos. A mistura deve ser processada em pista, com a seleção de solo feita pela projetista ou fiscalizadora, não pela usina recicladora, a não ser que esta possua laboratório de solos montado e conhecimento técnico sobre o assunto. 


\subsubsection{Controle tecnológico de execução}

A apresentação dos resultados do controle tecnológico de execução é separada em análise da umidade e análise do grau de compactação.

Os resultados apresentados são referentes a extensão de 1.020 metros aqui analisada, compreendendo amostras de agregados reciclados de duas proveniências: Santo André e São Bernardo do Campo.

\subsubsection{Umidade}

De acordo com a NBR 15115 (ABNT, 2004), devem ser realizados ensaios para conferir a umidade do agregado reciclado a cada $700 \mathrm{~m}^{2}$ de pista, imediatamente antes da compactação. Para a extensão de 1.020 metros de pavimento aqui analisada, deveriam ser realizadas no mínimo 10 verificações de umidade para a camada de sub-base e 10 para a base. De acordo com os relatórios de acompanhamento, para este trecho em estudo foram conduzidas nove determinações da umidade: três na camada de sub-base e seis na camada de base.

As amostras empregadas nas camadas, cujas umidades antes da compactação foram controladas, são as amostras Santo André (1), Santo André (4) e São Bernardo (2). Estas amostras são as mesmas submetidas aos ensaios de controle dos subitens 5.4.1. A Tabela 5.28 apresenta os resultados de umidade de compactação observados em campo, com as respectivas variações em relação à umidade ótima. 
Tabela 5.28: Resultados do controle da umidade de compactação dos agregados reciclados empregados nas camadas de base e sub-base do sistema viário da USP

Leste

\begin{tabular}{|c|c|c|c|c|c|}
\hline Amostra & $\begin{array}{c}\text { Local } \\
{[\mathrm{km}]}\end{array}$ & Camada & $\begin{array}{c}\text { Umidade } \\
\text { ótima } \\
{[\%]}\end{array}$ & $\begin{array}{c}\text { Umidade de } \\
\text { compactação } \\
{[\%]}\end{array}$ & $\begin{array}{c}\text { Variação de } \\
\text { umidade } \\
{[\%]}\end{array}$ \\
\hline $\begin{array}{c}\text { Santo André } \\
(1)\end{array}$ & 0,190 & base & 13,4 & 15,2 & $+1,8$ \\
\hline $\begin{array}{c}\text { Santo André } \\
(1)\end{array}$ & 0,210 & base & 13,4 & 14,9 & $+1,5$ \\
\hline $\begin{array}{c}\text { Santo André } \\
(1)\end{array}$ & 0,230 & base & 13,4 & 15,9 & $+2,5$ \\
\hline $\begin{array}{c}\text { São Bernardo } \\
(2)\end{array}$ & 0,570 & sub-base & 15,3 & 14,7 & $-0,6$ \\
\hline $\begin{array}{c}\text { São Bernardo } \\
(2)\end{array}$ & 0,760 & base & 15,3 & 14,9 & $-0,4$ \\
\hline $\begin{array}{c}\text { Santo André } \\
(4)\end{array}$ & 0,940 & sub-base & 16,3 & 15,5 & $-0,8$ \\
\hline $\begin{array}{c}\text { Santo André } \\
(4)\end{array}$ & 0,940 & base & 16,3 & 15,0 & $-1,3$ \\
\hline $\begin{array}{c}\text { Santo André } \\
(4)\end{array}$ & 0,970 & sub-base & 16,3 & 14,9 & $-1,4$ \\
\hline $\begin{array}{c}\text { Santo André } \\
(4)\end{array}$ & 0,970 & base & 16,3 & 14,7 & $-1,6$ \\
\hline
\end{tabular}

Analisando os valores de umidade das camadas de base e sub-base compactadas em campo, verifica-se que a variação de umidade ficou entre 2,5 acima e 1,6 abaixo da ótima. De acordo com a NBR 15115 (ABNT, 2004), o teor de umidade da mistura em campo deve ficar no intervalo entre $\pm 1,5 \%$ em relação à umidade obtida com o ensaio de laboratório. Assim, a variação da umidade de compactação de campo não se encontrou em todos os pontos dentro dos limites da norma.

Com a variabilidade dos agregados reciclados, a quebra dos grãos proporcionada pela compactação pode fazer com que o material demande mais água para atingir seu peso específico aparente seco máximo. O aumento da quantidade de partículas finas implica na alteração da umidade de compactação em campo. Desse modo, não é desejável que o material tenha umidade menor que a obtida previamente em ensaio laboratorial de compactação. Portanto, a determinação da umidade em campo deve ser considerada apenas um indicativo, sendo importante a avaliação estrutural da camada do pavimento. 
Os locais em que a umidade ficou abaixo da ótima correspondem a um segmento que teve sua compactação prejudicada. Este fato ficou claro com os ensaios de avaliação estrutural apresentados ainda neste capítulo.

\subsubsection{Grau de compactação}

A NBR 15115 (ABNT, 2004) prescreve que o controle de compactação seja conduzido a cada 50m de pista, imediatamente após a compactação, alternando borda direita, eixo e borda esquerda. O controle dos 1.020 metros deveria apresentar cerca de 20 determinações do grau de compactação. No entanto, os relatórios de acompanhamento apresentam para este segmento apenas nove ensaios realizados: três na camada de sub-base e seis na base. Agregados reciclados provenientes de Santo André e São Bernardo do Campo constituem as camadas dos locais controlados. A Tabela 5.29 apresenta os resultados obtidos.

Tabela 5.29: Resultados do controle de compactação dos agregados reciclados empregados nas camadas de base e sub-base do sistema viário da USP Leste

\begin{tabular}{|c|c|c|c|c|c|}
\hline Amostra & $\begin{array}{c}\text { Local } \\
{[\mathrm{km}]}\end{array}$ & Camada & $\begin{array}{c}\text { Peso } \\
\text { específico } \\
\text { aparente seco } \\
\text { máximo } \\
{\left[\mathrm{kN} / \mathrm{m}^{3}\right]}\end{array}$ & $\begin{array}{c}\text { Peso } \\
\text { específico } \\
\text { aparente } \\
\text { seco campo } \\
{[\%]}\end{array}$ & $\begin{array}{c}\text { G. C. } \\
{[\%]}\end{array}$ \\
\hline Santo André (1) & 0,190 & base & 17,7 & 18,0 & 101,5 \\
\hline Santo André (1) & 0,210 & base & 17,7 & 18,1 & 101,9 \\
\hline Santo André (1) & 0,230 & base & 17,7 & 17,9 & 100,8 \\
\hline São Bernardo (2) & 0,570 & sub-base & 18,8 & 19,2 & 102,2 \\
\hline São Bernardo (2) & 0,760 & base & 18,8 & 19,2 & 102,3 \\
\hline Santo André (4) & 0,940 & sub-base & 17,6 & 17,5 & 99,7 \\
\hline Santo André (4) & 0,940 & base & 17,6 & 17,7 & 101,0 \\
\hline Santo André (4) & 0,970 & sub-base & 17,6 & 17,3 & 98,6 \\
\hline Santo André (4) & 0,970 & base & 17,6 & 17,9 & 102,2 \\
\hline \\
(v) Grau de compactação com relação à energia intermediária empregada no laboratório e prescrita na \\
norma. No entanto, no caso do projeto, foi solicitado no mínimo 95\% da energia modificada.
\end{tabular}


Observando os resultados da Tabela 5.29, verifica-se que em dois locais da sub-base o grau de compactação obtido ficou abaixo dos $100 \%$. Entretanto, para o conjunto das nove amostras, a relação apresentada na equação (15) é atendida.

Nos segmentos correspondentes aos locais $0,570 \mathrm{~km}, 0,760 \mathrm{~km}, 0,940 \mathrm{~km}$ e $0,970 \mathrm{~km}$, apesar da umidade estar abaixo da ótima, os resultados com o frasco de areia acusaram um grau de compactação acima de 100\%. Contudo, pela avaliação estrutural apresentada ainda neste capítulo, observou-se que em alguns destes locais, as camadas com agregado reciclado tiveram uma compactação ineficiente, pois não atenderam a recomendação de projeto de aumentar a energia de compactação com relação ao solicitado na NBR 15115 (ABNT, 2004).

Geralmente, o controle de compactação de materiais convencionais permite que sejam inferidas algumas propriedades geotécnicas determinadas previamente em laboratório. No caso do agregado reciclado, estas propriedades não podem ser deduzidas por ensaios simples de campo, em função das particularidades intrínsecas deste material.

Os estudos laboratoriais são executados com mais cuidado e seleção. Por exemplo, no caso do agregado aqui estudado, a parcela retida na peneira $19,0 \mathrm{~mm}$ é separada para a determinação da umidade ótima. Em campo, o material apresenta-se de forma integral, ocasionando uma quebra dos grãos com a compactação diferente do acompanhado em laboratório. Esta alteração na granulometria pode implicar no aumento de partículas finas, influenciando na umidade ótima. Além disso, muitas pesquisas têm mostrado uma grande dificuldade na determinação de um teor de umidade ótima para agregados reciclados, pois a natureza do material é muito variável e depende da amostragem.

Estes fatos reforçam que métodos de controle normalmente utilizados para materiais convencionais não são satisfatórios e/ou suficientes para o agregado reciclado de resíduo sólido da construção civil. Assim, tratando-se de material de grande potencial de variabilidade de absorção de água, peso específico e de graduação, é 
recomendável que se controle a deformabilidade ou a resistência, e não parâmetros indiretos como o peso específico aparente seco e a umidade de compactação. Estes são apenas indicativos.

\subsubsection{Dynamic Cone Penetrometer}

Os ensaios com o DCP não foram realizados ao longo de toda a extensão de 1.020 metros. Os locais e a camada da superfície sobre a qual foram realizados os ensaios são apresentados na Tabela 5.30.

Tabela 5.30: Locais e superfície do pavimento do sistema viário da USP Leste onde foram realizados os ensaios com o DCP

\begin{tabular}{|c|c|c|c|c|}
\hline \multicolumn{2}{|c|}{ Local $[\mathrm{km}]$} & Faixa & $\begin{array}{c}\text { Camada da } \\
\text { superfície }\end{array}$ & $\begin{array}{c}\text { Material da camada } \\
\text { da superfície }\end{array}$ \\
\hline \multirow{5}{*}{$\begin{array}{c}\text { Seção-tipo } \\
3\end{array}$} & 0,440 & esquerda & sub-base & agregado reciclado \\
\cline { 2 - 5 } & 0,450 & eixo & sub-base & agregado reciclado \\
\cline { 2 - 6 } & 0,460 & direita & sub-base & agregado reciclado \\
\cline { 2 - 6 } & 0,470 & eixo & sub-base & agregado reciclado \\
\cline { 2 - 6 } & 0,480 & eixo & sub-base & agregado reciclado \\
\cline { 2 - 6 } & 0,490 & esquerda & sub-base & agregado reciclado \\
\cline { 2 - 6 } & 0,610 & eixo & reforço de subleito & solo laterítico \\
\cline { 2 - 6 } & 0,680 & eixo & base & agregado reciclado \\
\cline { 2 - 6 } & 0,700 & direita & base & agregado reciclado \\
\cline { 2 - 6 } & 0,710 & esquerda & reforço de subleito & solo laterítico \\
\hline \multirow{5}{*}{4} & 0,830 & esquerda & subleito & solo natural \\
\cline { 2 - 6 } & 0,850 & eixo & subleito & solo natural \\
\cline { 2 - 6 } & 0,870 & esquerda & subleito & solo natural \\
\cline { 2 - 6 } & 0,890 & eixo & subleito & solo natural \\
\cline { 2 - 6 } & 0,900 & direita & subleito & solo natural \\
\hline
\end{tabular}

Os locais onde foram realizados os ensaios entre $0,440 \mathrm{~km}$ até $0,710 \mathrm{~km}$ correspondem à seção-tipo 3 (item 3.2 deste trabalho - Figura 3.2). Os levantamentos entre os locais $0,830 \mathrm{~km}$ e $0,900 \mathrm{~km}$ correspondem à seção-tipo 4 (item 3.2 deste 
trabalho - Figura 3.2) e foram feitos diretamente sobre o subleito, antes do recebimento do "rachão de entulho".

As penetrações realizadas sobre as camadas superiores permitiram que fossem também avaliadas as camadas subjacentes. Por exemplo, o ensaio realizado sobre a camada de base possibilitou a identificação da camada de sub-base e de reforço de subleito, por ter levado a profundidades de penetração do cone que atingiram as camadas subjacentes.

A análise do subleito só foi possível entre os locais $0,830 \mathrm{~km} \mathrm{e} 0,900 \mathrm{~km}$, correspondentes à seção-tipo 4 (item 3.2 deste trabalho - Figura 3.2). Nos locais entre $0,440 \mathrm{~km}$ e $0,710 \mathrm{~km}$, apesar do subleito ter sido alcançado com o ensaio DCP, este se apresentava muito contaminado pelo solo laterítico utilizado no reforço. Dessa forma, ficou difícil avaliar os resultados obtidos no subleito neste segmento, que não condiziam com o solo de fundação previamente caracterizado pelas sondagens realizadas.

Por meio do ensaio DCP é possível determinar as espessuras das camadas da estrutura. A Figura 5.18 ilustra uma das curvas do DCP e a forma de identificação das diferentes camadas para o local $0,690 \mathrm{~km}$. O ensaio neste ponto foi executado sobre a camada de base. As alterações na inclinação da curva DCP permitem que sejam identificadas as mudanças de camada. 


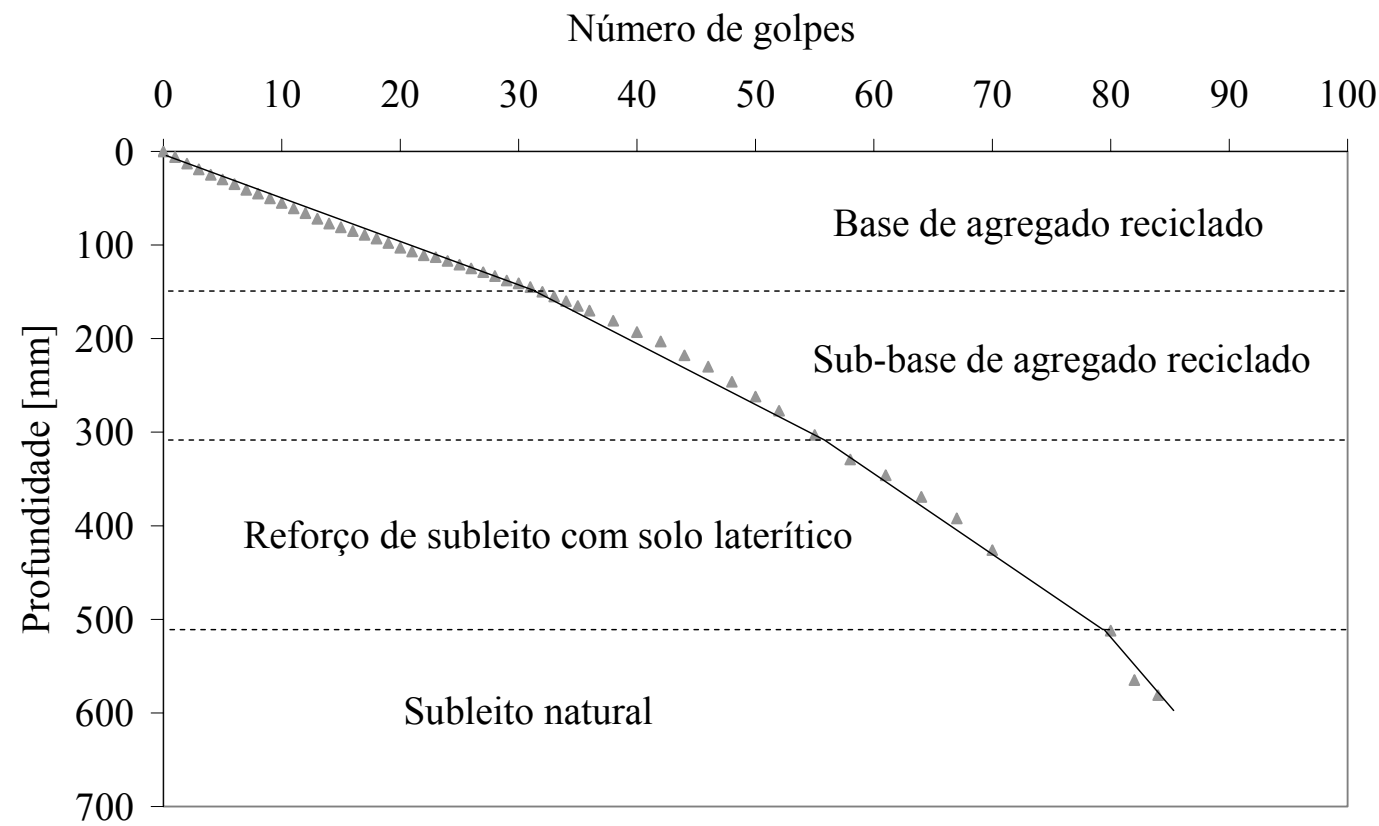

Figura 5.18: Curva DCP e determinação das espessuras das camadas do local $0,690 \mathrm{~km}$

Analisando a Figura 5.18 verifica-se que foram identificadas neste ponto $0,690 \mathrm{~km}$ quatro camadas: base, sub-base, reforço de subleito e subleito. As espessuras médias obtidas por meio do DCP para o segmento entre $0,440 \mathrm{~km}$ e $0,710 \mathrm{~km}$, correspondente à seção-tipo 3 (Figura 3.2), são apresentadas na Tabela 5.31.

Tabela 5.31: Espessuras das camadas do pavimento do sistema viário da USP Leste obtidas por meio do DCP entre os locais $0,440 \mathrm{~km}$ e $0,710 \mathrm{~km}$

\begin{tabular}{|c|c|c|c|c|c|}
\hline $\begin{array}{c}\text { Seção- } \\
\text { tipo }\end{array}$ & Camada & $\begin{array}{c}\text { Espessura de } \\
\text { projeto } \\
{[\mathrm{mm}]}\end{array}$ & $\begin{array}{c}\text { Espessura } \\
\text { média obtida } \\
\text { pelo DCP } \\
{[\mathrm{mm}]}\end{array}$ & $\begin{array}{c}\text { Desvio } \\
\text { padrão [mm] }\end{array}$ & $\begin{array}{c}\text { Coeficiente } \\
\text { de variação } \\
{[\%]}\end{array}$ \\
\hline 3 & Base & 150 & 149 & 5 & 3,4 \\
\hline 3 & Sub-base & 150 & 155 & 9 & 5,8 \\
\hline 3 & $\begin{array}{c}\text { Reforço de } \\
\text { subleito }\end{array}$ & 200 & 221 & 13 & 5,9 \\
\hline
\end{tabular}

De acordo com a Tabela 5.31, os coeficientes de variação indicam que as espessuras das camadas do pavimento foram praticamente constantes ao longo deste segmento do sistema viário da USP Leste. As espessuras médias verificadas com o DCP foram próximas às espessuras projetadas. Em outros locais não controlados pelo DCP 
ocorreram variações nas espessuras, em função de dificuldades que surgiram ao longo da obra e que exigiram algumas alterações.

Além da espessura, a curva DCP permite determinar a quantidade de golpes necessária para a penetração, verificando-se a resistência das camadas. Esta resistência é avaliada pelo índice de penetração DPI. Os valores médios de DPI, bem como os desvios padrão e coeficientes de variação para o trecho monitorado são apresentados na Tabela 5.32.

Tabela 5.32: Valores de DPI obtidos para as camadas do pavimento do sistema viário da USP Leste entre os locais $0,440 \mathrm{~km}$ e $0,900 \mathrm{~km}$

\begin{tabular}{|c|c|c|c|c|}
\hline $\begin{array}{c}\text { Seção- } \\
\text { tipo }\end{array}$ & Camada & $\begin{array}{c}\text { DPI médio } \\
{[\mathrm{mm} / \text { golpe }]}\end{array}$ & $\begin{array}{c}\text { Desvio padrão } \\
{[\mathrm{mm} / \text { golpe }]}\end{array}$ & $\begin{array}{c}\text { Coeficiente de } \\
\text { variação } \\
{[\%]}\end{array}$ \\
\hline 3 & Base & 4,62 & 0,08 & 1,7 \\
\hline 3 & Sub-base & 5,53 & 1,32 & 23,9 \\
\hline 3 & $\begin{array}{c}\text { Reforço de } \\
\text { Subleito }\end{array}$ & 9,07 & 2,60 & 28,7 \\
\hline 4 & $\begin{array}{c}\text { Subleito antes de } \\
\text { receber "rachão } \\
\text { de entulho" }\end{array}$ & 115,22 & 15,47 & 13,4 \\
\hline
\end{tabular}

Quanto menor o valor de DPI, maior é a resistência da camada à penetração. Analisando os resultados apresentados, é possível verificar que o DPI médio da camada de base é menor do que o DPI médio da camada de sub-base. Como as duas camadas são constituídas pelo mesmo material (agregado reciclado) e espessura $(150 \mathrm{~mm})$, este fato indica uma compactação mais eficiente na camada de base, por apresentar-se mais resistente que a sub-base e ter uma melhor camada de suporte para promover o serviço de compactação. Além disso, analisando o desvio padrão e o coeficiente de variação, percebe-se uma homogeneidade maior na camada de base. Contudo, a escassez de amostras na camada de base, não permite que seja garantida a sua uniformidade ao longo de toda a extensão.

Quanto ao DPI médio da camada de reforço de subleito, o material empregado foi um solo laterítico, que se apresentou menos resistente que a camada de sub-base. $\mathrm{O}$ 
alto coeficiente de variação do DPI na camada de reforço de subleito indica que a eficiência da compactação não foi contínua ao longo da obra. O subleito da seçãotipo 4 (Figura 3.2), que foi analisado antes de receber o "rachão de entulho", apresentou um DPI médio muito elevado $(115,22 \mathrm{~mm} / \mathrm{golpe})$, indicando a baixa capacidade de suporte do solo de fundação, influenciando na dificuldade de compactação do reforço do subleito.

Resultados de DPI normalmente são analisados por meio de correlações. Algumas correlações com índice de suporte Califórnia encontradas na bibliografia consultada são apresentadas na Tabela 5.33. Os valores de ISC são em \% e os de DPI em $\mathrm{mm} /$ golpe.

Tabela 5.33: Correlações entre DPI e índice de suporte Califórnia in situ para diferentes materiais verificadas na bibliografia consultada

\begin{tabular}{|c|c|c|c|}
\hline Material & Local & Modelo obtido & Autor \\
\hline $\begin{array}{l}\text { Solo residual de } \\
\text { granito das classes } \\
\text { A-2-4, A-4, A-7-6 }\end{array}$ & $\begin{array}{c}\text { Santo Amaro da } \\
\text { Imperatriz/ SC } \\
\text { Brasil }\end{array}$ & $\mathrm{ISC}=512,64 / \mathrm{DPI}^{1,25}$ & $\begin{array}{l}\text { Trichês e } \\
\text { Cardoso } \\
\text { (1999) }\end{array}$ \\
\hline $\begin{array}{c}\text { Resíduos de } \\
\text { construção civil do } \\
\text { tipo misto }\end{array}$ & $\begin{array}{c}\text { Floranópolis/SC } \\
\text { Brasil }\end{array}$ & $\mathrm{ISC}=126,35 / \mathrm{DPI}^{0,6354(\mathrm{x})}$ & $\begin{array}{l}\text { Kryckyj e } \\
\text { Trichês } \\
\text { (2000) }\end{array}$ \\
\hline $\begin{array}{l}\text { Solo laterítico } \\
\text { argiloso LG' }\end{array}$ & $\begin{array}{c}\text { Maringá/PR } \\
\text { Brasil }\end{array}$ & $\mathrm{ISC}=257,04 / \mathrm{DPI}^{1,091}$ & $\begin{array}{c}\text { Lima } \\
(2000)\end{array}$ \\
\hline $\begin{array}{c}\text { Não foi especificado } \\
\text { o tipo de material }\end{array}$ & África do Sul & $\mathrm{ISC}=427,56 / \mathrm{DPI}^{1,280}$ & $\begin{array}{l}\text { Kleyn } \\
(1975)\end{array}$ \\
\hline \multirow{2}{*}{$\begin{array}{l}\text { Materiais granulares } \\
\text { e coesivos }\end{array}$} & \multirow[b]{2}{*}{ Estados Unidos } & $\mathrm{ISC}=292 / \mathrm{DPI}^{1,12}$ & \multirow{2}{*}{$\begin{array}{c}\text { U.S. Army } \\
\text { Corps of } \\
\text { Engineers } \\
(1994)^{5}\end{array}$} \\
\hline & & $\mathrm{ISC}=1 /\left(\underset{(\mathrm{z})}{(0,017019 \mathrm{DPI})^{2}}\right.$ & \\
\hline
\end{tabular}

${ }^{5}$ Retirado de Siekmeier et al. (1999) apud Webster et al. (1994). WEBSTER, S.L.; BROWN, R. W.; PORTER, J. R. Force projection site evaluation using the Electric Cone Penetrometer and the Dynamic Cone Penetrometer. Technical Report GL-94-17, U. S. Waterways Experimental Station, 1994. 
Os valores médios de ISC obtidos pelas equações apresentadas são apresentados na Tabela 5.34 de acordo com cada camada.

Tabela 5.34: Cálculo do índice de suporte Califórnia in situ para diferentes materiais conforme correlações com o DPI verificadas na bibliografia consultada

\begin{tabular}{|c|c|c|c|c|c|c|}
\hline \multirow{2}{*}{$\begin{array}{c}\text { Seção- } \\
\text { tipo }\end{array}$} & Camada & $\begin{array}{c}\text { Trichês e } \\
\text { Cardoso } \\
(1999)\end{array}$ & $\begin{array}{c}\text { Kryckyj } \\
\text { e Trichês } \\
(2000)\end{array}$ & $\begin{array}{c}\text { Lima } \\
(2000)\end{array}$ & $\begin{array}{c}\text { Kleyn } \\
(1975)\end{array}$ & $\begin{array}{c}\text { U.S. Army } \\
\text { Corps of } \\
\text { Engineers } \\
(1994)\end{array}$ \\
\hline 3 & Base & - & 48 & - & 60 & $53^{(\mathrm{y})}$ \\
\hline 3 & Sub-base & - & 43 & - & 52 & $46^{(\mathrm{y})}$ \\
\hline 3 & $\begin{array}{c}\text { Reforço } \\
\text { de subleito }\end{array}$ & 37 & - & 26 & 29 & $27^{(\mathrm{y})}$ \\
\hline 4 & Subleito & 1,4 & - & 1,5 & 1,0 & $0,3^{(\mathrm{z})}$ \\
\hline
\end{tabular}

${ }^{(y)}$ Calculados com o modelo para materiais com ISC $>10 \%$

(z) Calculados com o modelo para materiais com ISC $<10 \%$

Analisando os resultados apresentados na Tabela 5.34, observa-se que a correlação desenvolvida por Kryckyj e Trichês (2000) para resíduos da construção civil indicaram um ISC menor que o modelo do U.S. Army Corps of Engineers (USACE). Ao empregar o DCP é muito importante estabelecer correlações para o material estudado, pois adotar correlações criadas para materiais diferentes torna os valores de ISC distantes da realidade do campo. De acordo com a bibliografia internacional consultada, geralmente emprega-se as correlações do (USACE), por ter sido estabelecida para uma grande variedade de materiais granulares e coesivos. Além disso, as correlações USACE consideram o ISC do material obtido em laboratório, pois as equações diferem para materiais com ISC maior ou menor que $10 \%$.

Neste trabalho, para todos os DPI obtidos, entre os locais $0,440 \mathrm{~km}$ e $0,710 \mathrm{~km}$ (correspondente à seção-tipo 3 - Figura 3.2), foram calculados os ISC pelo método do USACE para cada camada avaliada. Os resultados são apresentados em forma gráfica na Figura 5.19. 


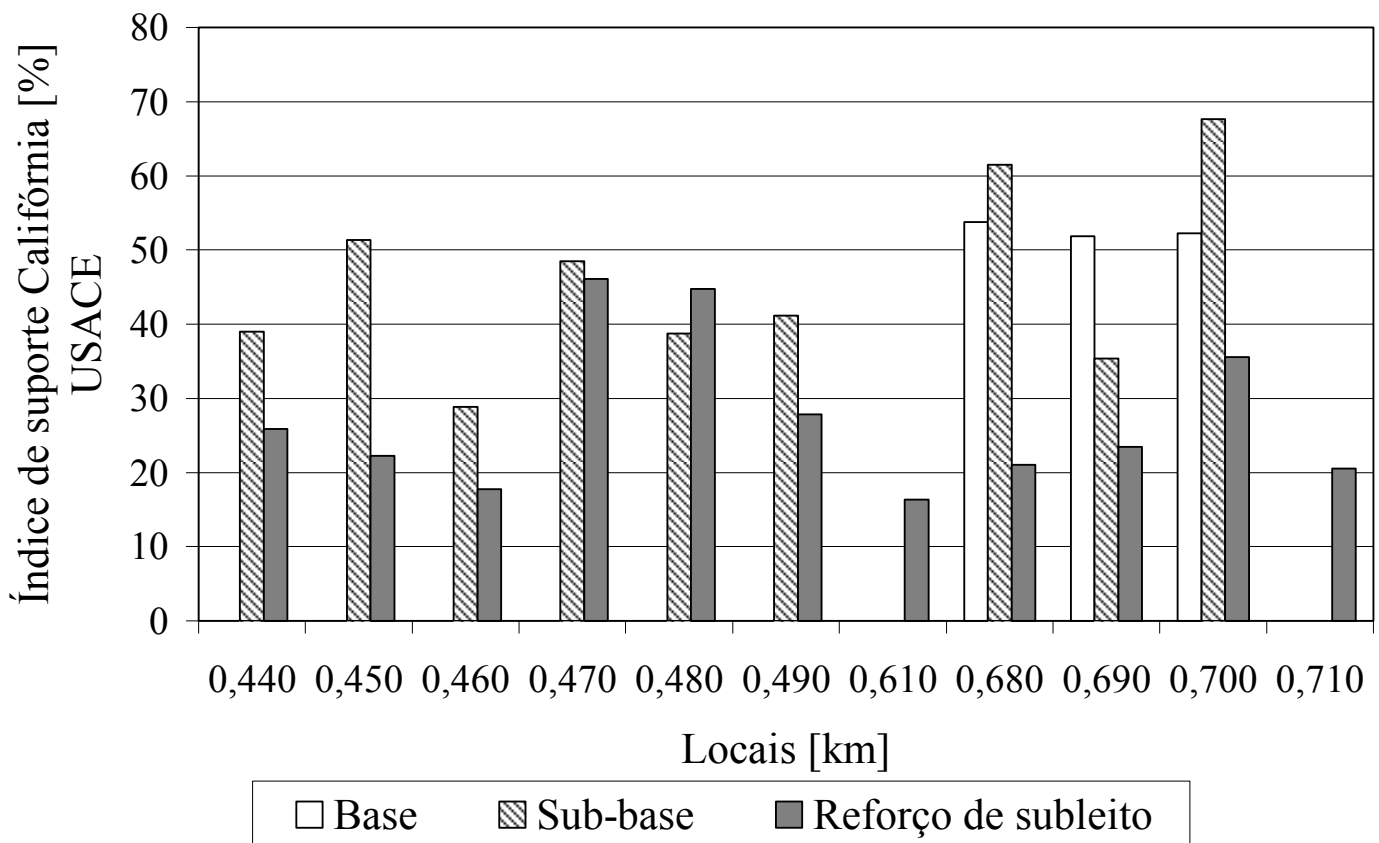

Figura 5.19: Resultados de ISC pelo modelo do USACE (1994) para as camadas do pavimento analisadas entre os locais $0,440 \mathrm{~km}$ e $0,710 \mathrm{~km}$

Para cada camada aplicou-se o modelo do USACE e fez-se uma análise estatística determinando o ISC médio, desvio padrão, coeficiente de variação e ISC mínimo estatístico. O ISC mínimo estatístico é calculado pela expressão (17):

$$
I S C_{\text {min }}=I S C_{\text {médio }}-\frac{1,29 \times S}{\sqrt{n}}
$$

onde:

$I S C_{\text {min }}:$ índice de suporte Califórnia mínimo estatístico;

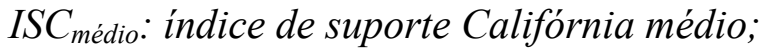

S: desvio padrão;

n: número de amostras.

Para atender as condições de projeto, o ISC mínimo estatístico deve ser maior que o ISC especificado para a camada. Os resultados obtidos são apresentados na Tabela 5.35 . 
Tabela 5.35: Valores de ISC médio, desvio padrão, coeficiente de variação e ISC mínimo estatístico obtidos para as camadas submetidas a ensaios DCP entre os locais $0,440 \mathrm{~km}$ e $0,710 \mathrm{~km}$, utilizando o modelo USACE

\begin{tabular}{|c|c|c|c|c|c|c|}
\hline $\begin{array}{c}\text { Seção- } \\
\text { tipo }\end{array}$ & Camada & $\begin{array}{c}\text { ISC de } \\
\text { projeto } \\
{[\%]}\end{array}$ & $\begin{array}{c}\text { ISC } \\
\text { médio } \\
\text { USACE } \\
{[\%]}\end{array}$ & $\begin{array}{c}\text { Desvio } \\
\text { padrão [\%] }\end{array}$ & $\begin{array}{c}\text { Coeficiente } \\
\text { de variação } \\
{[\%]}\end{array}$ & $\begin{array}{c}\text { ISC } \\
\text { mínimo } \\
{[\%]}\end{array}$ \\
\hline 3 & Base & $\geq 60$ & 53 & 1 & 1,9 & 52 \\
\hline 3 & Sub-base & $\geq 20$ & 46 & 13 & 27,6 & 40 \\
\hline 3 & $\begin{array}{c}\text { Reforço de } \\
\text { subleito }\end{array}$ & $\geq 10$ & 27 & 10 & 37,6 & 23 \\
\hline
\end{tabular}

Pelos resultados apresentados é possível verificar que aplicando o modelo de correlação do USACE, o agregado reciclado da base não atingiu o valor de ISC de no mínimo $60 \%$ para emprego em camadas de base de pavimentos com $\mathrm{N}<10^{6}$ (ABNT, 2004). As outras camadas atenderam o projeto, pois na sub-base e no reforço de subleito o ISC ficou maior que $20 \%$ e $10 \%$, respectivamente.

Assim, conclui-se que o DCP é uma importante ferramenta no controle tecnológico durante a construção de pavimentos, por permitir que seja prevista e estimada a uniformidade da compactação e a capacidade de suporte da camada.

\subsubsection{Falling Weight Deflectometer}

Os resultados obtidos com o FWD nas quatro seções-tipo de pavimento construídas no campus da USP Leste foram estudados separadamente. Cada trecho correspondente a uma seção-tipo foi considerado um segmento homogêneo. Os segmentos homogêneos (Seg. Hom.) são apresentados na Tabela 5.36. É importante ressaltar que dentro do segmento homôgeneo 3 foram desconsideradas as bacias de deflexão medidas entre $0,260 \mathrm{~km}$ e $0,330 \mathrm{~km}$, trecho onde foi empregado o material asfáltico fresado sobre a camada de base, como relatado no item 3.4 deste trabalho. 
Tabela 5.36: Segmentos homogêneos analisados neste trabalho (cotas em $\mathrm{cm}$ )

\begin{tabular}{|c|c|c|c|c|c|}
\hline $\begin{array}{l}\text { Seg. } \\
\text { Hom. }\end{array}$ & $\begin{array}{c}\text { Extensão } \\
{[\mathrm{km}]}\end{array}$ & Seção-tipo & $\begin{array}{l}\text { Seg. } \\
\text { Hom. }\end{array}$ & $\begin{array}{c}\text { Extensão } \\
{[\mathrm{km}]}\end{array}$ & Seção-tipo \\
\hline 1 & $\begin{array}{c}0,000 \\
a \\
0,160\end{array}$ & 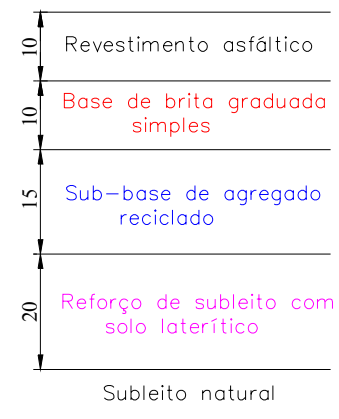 & 2 & $\begin{array}{c}0,160 \\
a \\
0,240\end{array}$ & 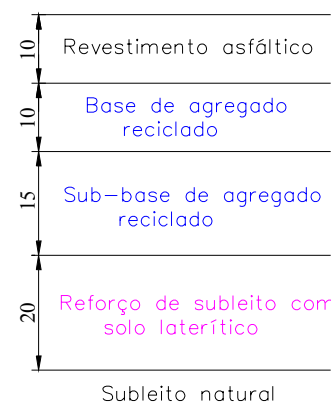 \\
\hline 3 & $\begin{array}{c}0,240 \\
\mathrm{a} \\
0,720\end{array}$ & 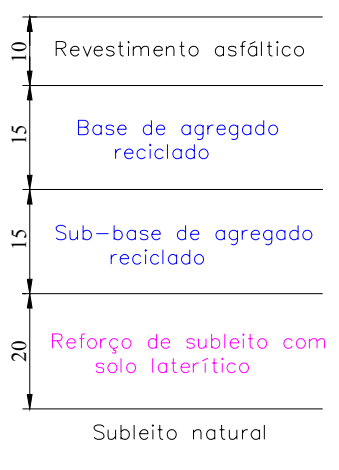 & 4 & $\begin{array}{c}0,720 \\
\mathrm{a} \\
1,020\end{array}$ & 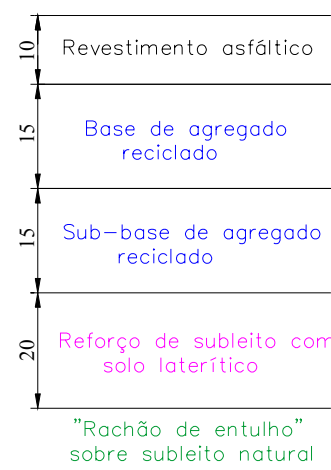 \\
\hline
\end{tabular}

A Figura 5.20 apresenta as bacias de deflexão média medidas na faixa esquerda, eixo e faixa direita do pavimento do primeiro segmento homogêneo. Este segmento correspondente à seção-tipo 1, que possui brita graduada simples na camada de base e agregado reciclado na camada de sub-base. 


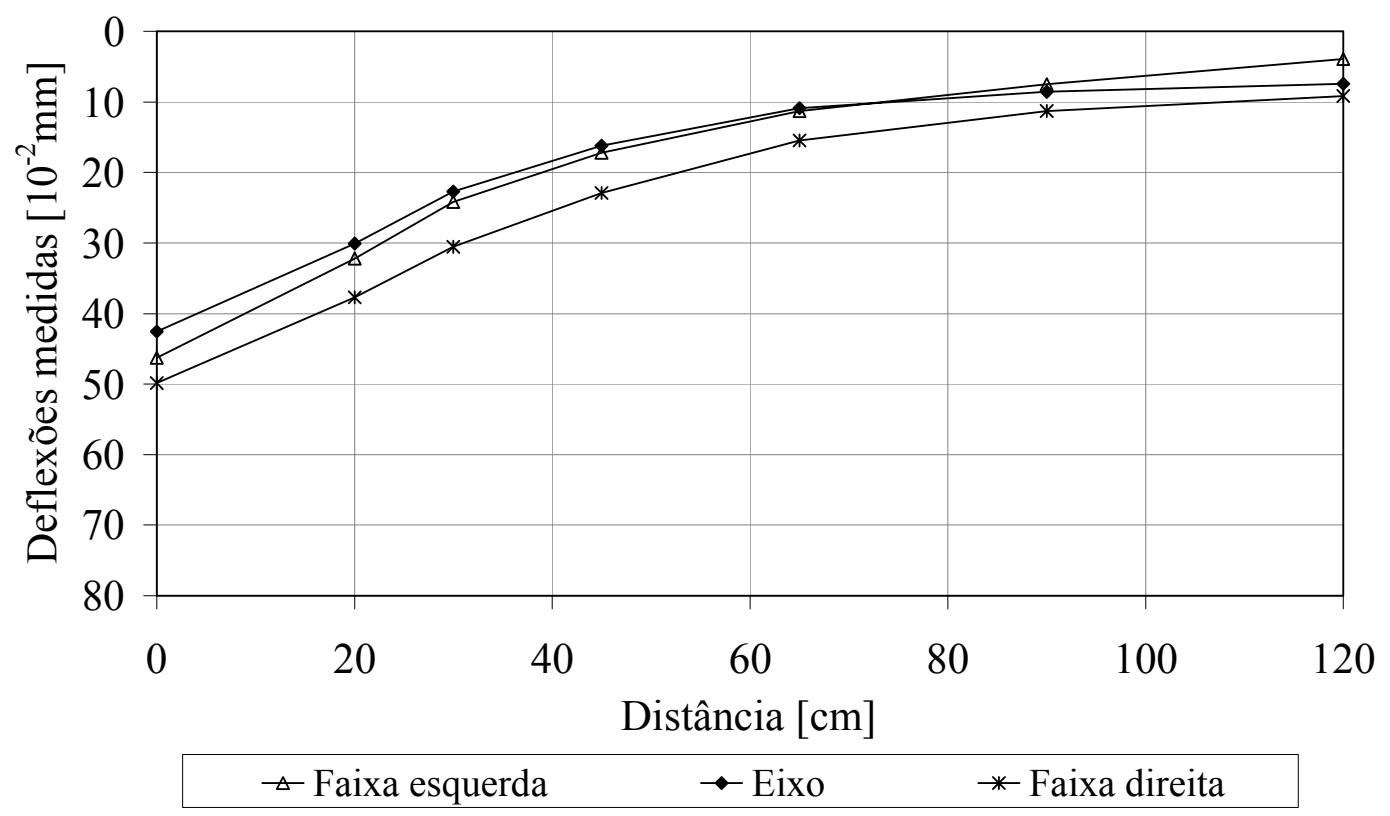

Figura 5.20: Bacias de deflexão médias medidas em campo para o segmento homogêneo 1 - seção-tipo 1

Pelo gráfico apresentado é possível observar que há uma diferença entre as faixas direita e esquerda e o eixo. O eixo apresenta o menor valor de deflexão logo abaixo da aplicação da carga. Esta variação das bacias de deflexão mostra que a compactação não foi homogênea ao longo da seção transversal do pavimento, ou ainda que a drenagem precária do pavimento influencia no aumento das deflexões junto às bordas.

As bacias de deflexão médias do segundo segmento homogêneo, correspondente à seção-tipo 2 com base e sub-base de agregado reciclado, são apresentadas na Figura 5.21. O gráfico contém a média dos levantamentos das faixas esquerda, direita e eixo. 


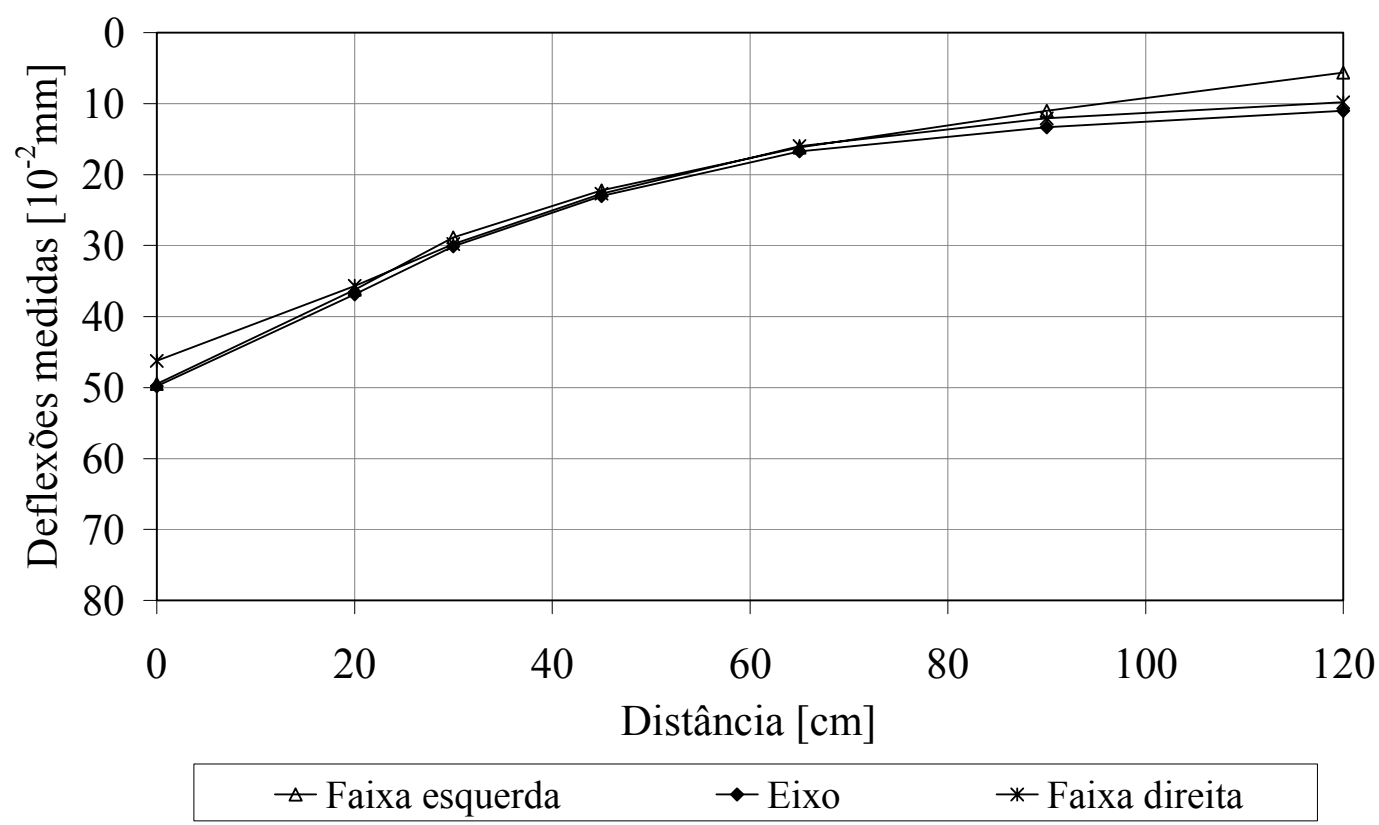

Figura 5.21: Bacias de deflexão médias medidas em campo para o segmento homogêneo 2 - seção-tipo 2

Observando a Figura 5.21 verifica-se que a média das deflexões medidas logo abaixo do ponto de aplicação da carga nas faixas direita e esquerda e no eixo encontram-se em torno de $50 \times 10^{-2} \mathrm{~mm}$. As bacias de deflexão média apresentam-se muito semelhantes. Este fato indica uma boa homogeneidade na compactação.

A Figura 5.22 apresenta as bacias de deflexão médias obtidas no segmento 3, seçãotipo 3, que também possui base e sub-base de agregado reciclado. 


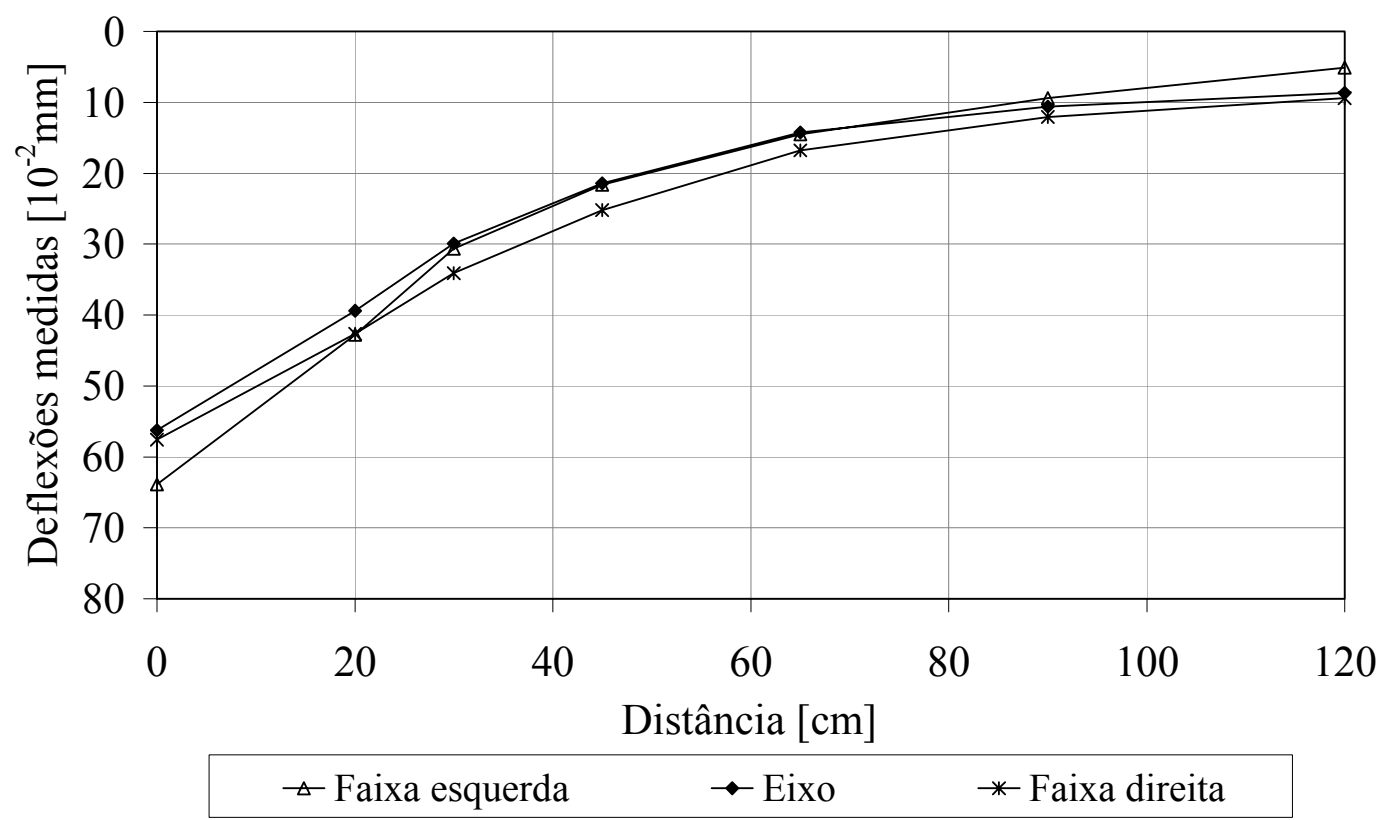

Figura 5.22: Bacias de deflexão médias medidas em campo para o segmento homogêneo 3 - seção-tipo 3

Pela Figura 5.22 observa-se que as médias das deflexões máximas medidas nas faixas direita e esquerda e no eixo apresentam-se mais elevadas que nos segmentos 1 e 2, indicando uma compactação deficiente no segmento 3.

A Figura 5.23 apresenta as bacias de deflexão médias medidas no quarto segmento homogêneo, que possui a seção-tipo 4 com "rachão de entulho". 


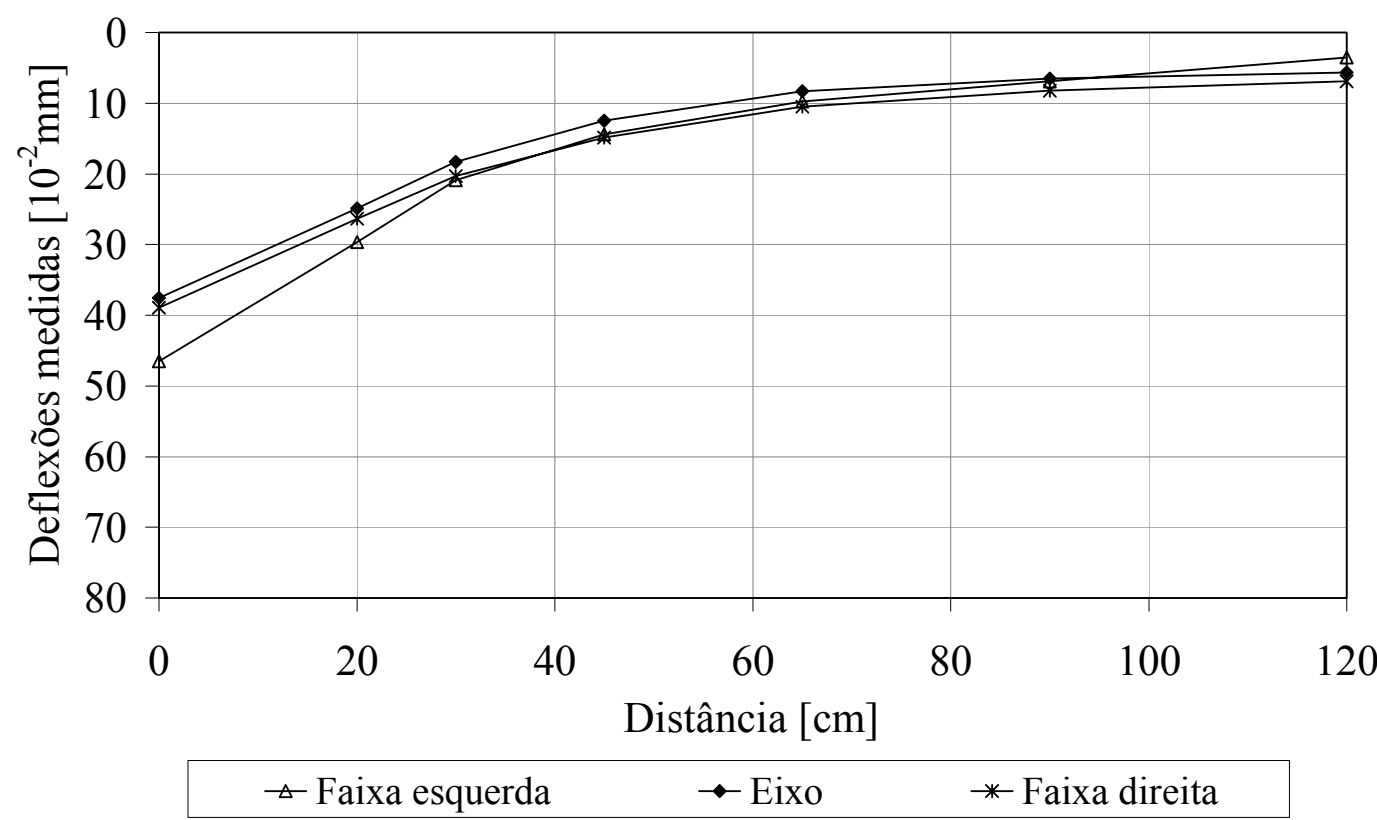

Figura 5.23: Bacias de deflexão médias medidas em campo para o segmento homogêneo 4 - seção-tipo 4

O quarto segmento apresentou as bacias de deflexão médias com os menores valores de deflexão. Apesar do pavimento da seção-tipo 4 ter a mesma estrutura da seçãotipo 3, a presença do "rachão de entulho" melhorou a resposta do pavimento quanto à deformabilidade. Houve uma queda nos valores de deflexões, em função do emprego do "rachão de entulho", que possibilitou uma compactação mais eficiente das camadas superiores.

A Tabela 5.37 apresenta um resumo dos valores médios de deflexão máxima $\left(\mathrm{d}_{0}\right)$, de deflexão afastada a $25 \mathrm{~cm}$ da carga $\left(\mathrm{d}_{25}\right)$ e do raio de curvatura $\left(\mathrm{R}_{\mathrm{c}}\right)$, para as faixas esquerda e direita, e eixo dos quatro segmentos homogêneos. 
Tabela 5.37: Valores de $d_{0}, d_{25}$ e $R_{c}$ médios da faixa esquerda, do eixo e da faixa direita para os segmentos homogêneos das quatro seções-tipo aqui analisadas

\begin{tabular}{|c|c|c|c|c|}
\hline $\begin{array}{c}\text { Segmento } \\
\text { Homogêneo }\end{array}$ & Faixa & $\begin{array}{c}\mathrm{d}_{0} \\
{\left[\mathrm{x} 10^{-2} \mathrm{~mm}\right]}\end{array}$ & $\begin{array}{c}\mathrm{d}_{25} \\
{\left[\times 10^{-2} \mathrm{~mm}\right]}\end{array}$ & $\begin{array}{c}\mathrm{R}_{\mathrm{c}} \\
{[\mathrm{m}]}\end{array}$ \\
\hline \multirow{3}{*}{1} & esquerda & 46 & 28 & 178 \\
\cline { 2 - 5 } & eixo & 43 & 26 & 206 \\
\cline { 2 - 5 } & direita & 50 & 34 & 211 \\
\hline \multirow{3}{*}{2} & esquerda & 49 & 33 & 190 \\
\cline { 2 - 5 } & eixo & 50 & 34 & 195 \\
\cline { 2 - 5 } & direita & 50 & 35 & 234 \\
\hline \multirow{3}{*}{3} & esquerda & 64 & 37 & 117 \\
\cline { 2 - 5 } & eixo & 56 & 35 & 151 \\
\cline { 2 - 5 } & direita & 58 & 38 & 173 \\
\hline \multirow{3}{*}{4} & esquerda & 46 & 25 & 184 \\
\cline { 2 - 5 } & eixo & 38 & 22 & 224 \\
\cline { 2 - 5 } & direita & 39 & 23 & 227 \\
\hline
\end{tabular}

Analisando os resultados apresentados, é possível verificar que as deflexões e os raios de curvatura nas seções-tipo 1 e 2 são muito similares, demonstrando que o comportamento da brita graduada simples (seção-tipo 1) e do agregado reciclado (seção-tipo 2) são próximos.

No terceiro segmento, a compactação do agregado reciclado foi um pouco deficiente, observando-se deflexões mais elevadas e raios de curvatura menores. Este fato aponta o aumento da deformabilidade em função da compactação deficiente.

O quarto segmento, pertinente a seção-tipo 4, apresenta os melhores resultados. As deflexões são baixas e os raios de curvatura elevados. Assim, o emprego do "rachão de entulho" no subleito melhorou as condições de compactação.

Para cada segmento homogêneo, foram calculadas as deflexões características do eixo, faixa esquerda e faixa direita. A deflexão característica é calculada pela expressão (18):

$d_{\text {caracteristica }}=d_{0 \text { médio }}+S$ 
onde:

$d_{\text {caracteristica: }}$ deflexão característica do segmento homogêneo, em $\left[10^{-2} \mathrm{~mm}\right]$;

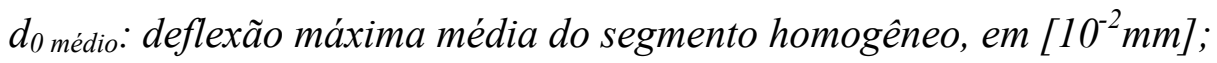

S: desvio padrão.

No caso do pavimento da USP Leste, a deflexão característica de cada segmento homogêneo deveria ser menor que a calculada por método teórico utilizando-se o programa computacional ELSYM5, durante o dimensionamento. Foi analisada a estrutura de pavimento da seção-tipo 3, utilizando-se os módulos apresentados na Tabela 4.6, e verificou-se uma deflexão máxima $\mathrm{d}_{0}$ de $65 \times 10^{-2} \mathrm{~mm}\left(\mathrm{~d}_{\text {projeto }}\right)$ e um raio de curvatura de 189 metros.

Para conferir se os valores de deflexão característica atendiam ao recomendado pelos órgãos rodoviários, foram calculadas as deflexões máximas admissíveis pelo modelo do método DNER PRO 011/79 (DNER, 1979) apresentada na expressão (19).

$\log d_{a d m}=3,01-0,176 \log N$

onde:

$d_{a d m}$ : deflexão máxima admissivel medida sobre a camada de revestimento, em $\left[10^{-2} \mathrm{~mm}\right]$;

N: número de solicitações do eixo padrão de 8,2 toneladas durante o período de projeto.

Para o cálculo das deflexões admissíveis foi utilizado um $\mathrm{N}$ igual a $10^{6}$. Os resultados obtidos são apresentados na Tabela 5.38. 
Tabela 5.38: Valores de $\mathrm{d}_{0 \text { médio }}, \mathrm{d}_{\text {característica }}, \mathrm{d}_{\text {projeto }}$ e $\mathrm{d}_{\text {adm }}$ calculadas pelo método DNER PRO 011/79 (DNER, 1979)

\begin{tabular}{|c|c|c|c|c|c|}
\hline \multirow{2}{*}{$\begin{array}{l}\text { Segmento } \\
\text { homogêneo }\end{array}$} & \multirow{2}{*}{ Faixa } & \multicolumn{4}{|c|}{ Deflexões $\left[\mathrm{x} 10^{-2} \mathrm{~mm}\right]$} \\
\hline & & $\mathrm{d}_{0 \text { médio }}$ & $\mathrm{d}_{\text {característica }}$ & $\mathrm{d}_{\text {projeto }}$ & $\begin{array}{c}\text { PRO } 011 \\
\mathrm{~d}_{\mathrm{adm}}\end{array}$ \\
\hline \multirow{3}{*}{1} & esquerda & 46 & 54 & \multirow{3}{*}{65} & \multirow{3}{*}{90} \\
\hline & eixo & 43 & 52 & & \\
\hline & direita & 50 & 65 & & \\
\hline \multirow{3}{*}{2} & esquerda & 49 & 56 & \multirow{3}{*}{65} & \multirow{3}{*}{90} \\
\hline & eixo & 50 & 54 & & \\
\hline & direita & 50 & 60 & & \\
\hline \multirow{3}{*}{3} & esquerda & 64 & 74 & \multirow{3}{*}{65} & \multirow{3}{*}{90} \\
\hline & eixo & 56 & 68 & & \\
\hline & direita & 58 & 70 & & \\
\hline \multirow{3}{*}{4} & esquerda & 46 & 58 & \multirow{3}{*}{65} & \multirow{3}{*}{90} \\
\hline & eixo & 38 & 47 & & \\
\hline & direita & 39 & 48 & & \\
\hline
\end{tabular}

Pelos resultados apresentados é possível verificar que todos os segmentos homogêneos tiveram deflexões características menores que as deflexões admissíveis calculadas pelo método DNER PRO 011/79 (DNER, 1979). Entretanto, o segmento homogêneo 3 não teve deflexões características abaixo das deflexões esperadas pelo projeto. Este fato reforça que as camadas de base e sub-base com agregado reciclado no segmento homogêneo 3 não tiveram uma compactação eficiente.

A Figura 5.24 apresenta uma comparação das bacias de deflexão médias medidas no eixo durante o $2^{\circ}$ levantamento deflectométrico, para os segmentos homogêneos $1 \mathrm{e}$ 2. 


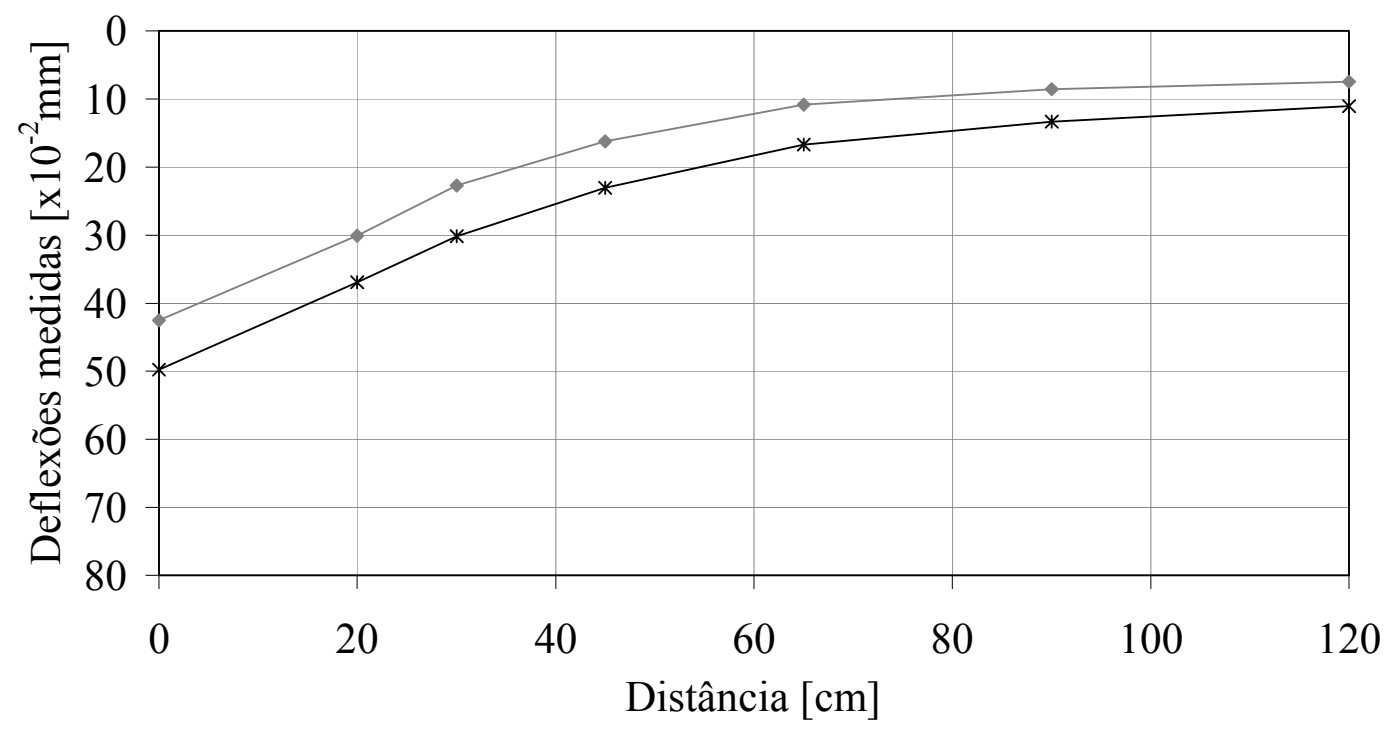

Eixo - segmento homogêneo 1

Eixo - segmento homogêneo 2

Figura 5.24: Análise das bacias de deflexão médias medidas no eixo para os segmentos homogêneos 1 e 2

Pela Figura 5.24 observa-se que as bacias de deflexão médias medidas no eixo, indicaram uma diferença entre os segmentos 1 e 2. O subleito apresenta-se mais resistente no eixo, o que influenciou na queda da deflexão máxima $\left(\mathrm{d}_{0}\right)$. Não foi encontrada uma explicação para este fato nos relatórios de controle tecnológico da obra. Não se sabe se houve troca de solo no segmento homogêneo 1 para viabilizar o acesso à obra dos caminhões, uma vez que este trecho tem início nas proximidades da portaria (Portão 2), um local baixo perto de um canal de água.

Na Figura 5.25 são apresentadas as bacias de deflexão médias medidas no eixo para os segmentos homogêneos 2 e 3 . 


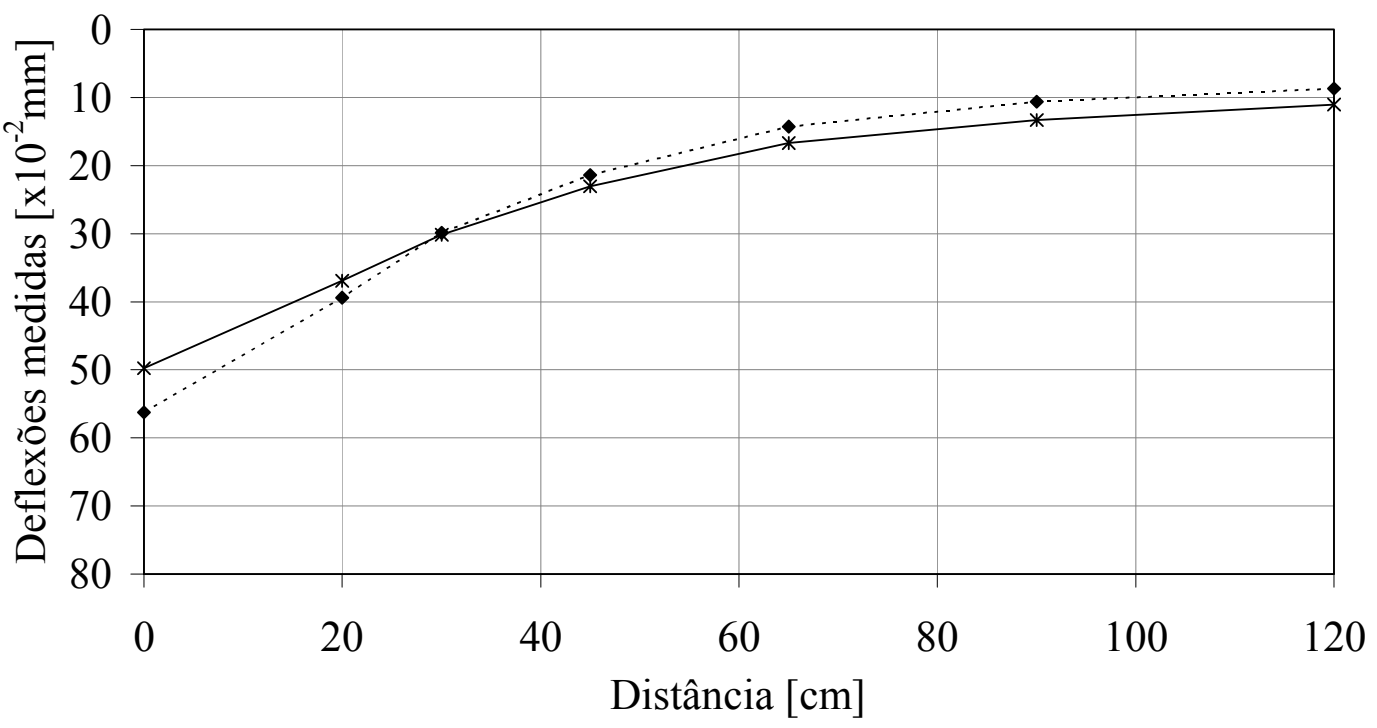

* Eixo - segmento homogêneo 2

-... Eixo - segmento homogêneo 3

Figura 5.25: Análise das bacias de deflexão médias medidas no eixo para os segmentos homogêneos 2 e 3

Comparando as bacias das seções-tipo 2 e 3, as deflexões e os raios de curvatura são diferentes, sendo a deflexão máxima maior e o raio de curvatura menor na seção 3. Este fato reforça que o desempenho do agregado reciclado depende de uma compactação eficiente.

A Figura 5.26 ilustra as bacias de deflexão médias medidas no eixo para os segmentos 3 e 4 (seção-tipo 3 e seção-tipo 4). 


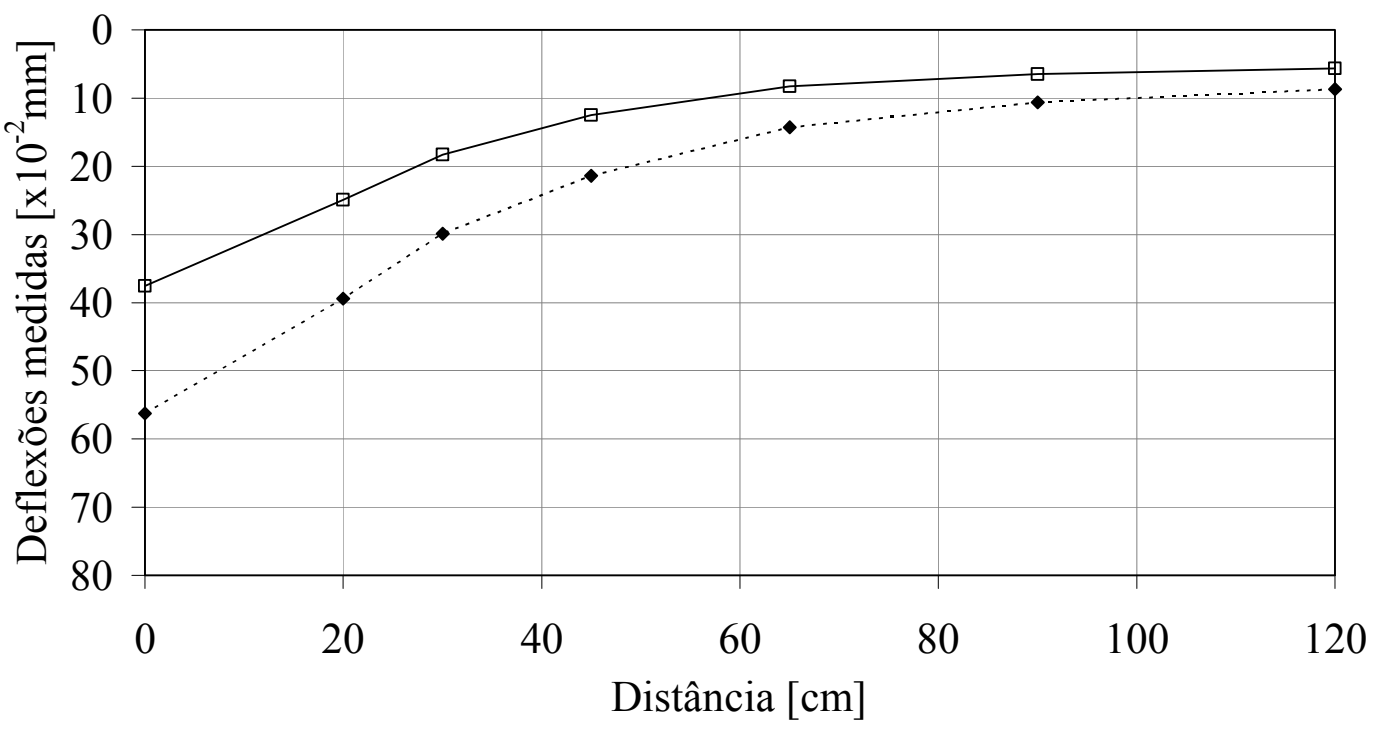

- Eixo - segmento homogêneo $3 \rightarrow$ Eixo - segmento homogêneo 4

Figura 5.26: Análise das bacias de deflexão médias medidas no eixo para os segmentos homogêneos 3 e 4

É possível verificar uma grande diferença entre as bacias de deflexão média do segmento homogêneo 3 e do segmento homogêneo 4. Apesar de terem a mesmas camadas de reforço de subleito, sub-base, base e reforço de subleito, a presença do "rachão de entulho" sobre o subleito melhorou muito a resposta da estrutura quanto à deformabilidade, reduzindo a deflexão e aumentando o raio de curvatura.

A Figura 5.27 faz uma comparação entre as bacias de deflexão médias dos segmentos homogêneos 1,2 e 4 . 


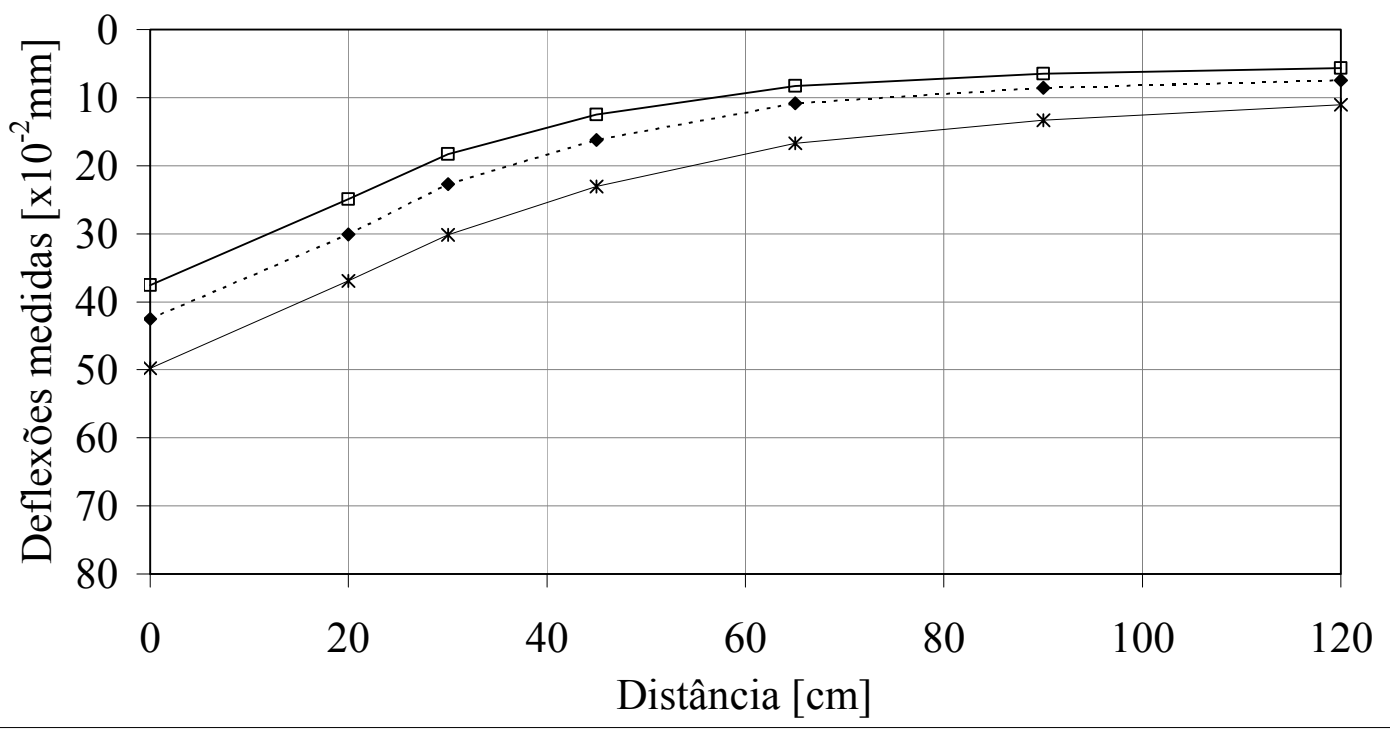

- Eixo - segmento homogêneo $1 \rightarrow$ Eixo - segmento homogêneo $2 \rightarrow$ Eixo - segmento homogêneo 4

Figura 5.27: Análise das bacias de deflexão médias medidas no eixo para os segmentos homogêneos 1,2 e 4

Observando a Figura 5.27 é possível verificar que as bacias dos segmentos homogêneos 1, 2 e 4 apresentam a mesma forma, tanto que os raios de curvatura são altos e próximos: $206 \mathrm{~m}, 195 \mathrm{~m}$ e $224 \mathrm{~m}$, respectivamente. Este fato indica o comportamento similar da camada de base nestes três segmentos. A menor deflexão máxima é a do segmento homogêneo 4, correspondente a seção-tipo com "rachão de entulho" sobre o subleito. Por meios destes resultados é possível concluir que o emprego do "rachão de entulho" melhorou a resposta da estrutura quando submetida ao carregamento.

Da mesma forma, como citado anteriormente, as pequenas diferenças entre as deflexões nos segmentos homogêneos 1 e 2 são em conseqüência da alteração na capacidade de suporte do subleito.

\subsection{Discussão sobre o comportamento em campo}

São apresentados os resultados obtidos com as retroanálises das bacias de deflexão medidas por meio do programa computacional ELSYM5. Cada bacia de deflexão medida no eixo do pavimento do sistema viário da USP Leste foi retroanalisada. 
Da Figura 5.28 a Figura 5.31 são apresentadas a média das bacias de deflexão medidas no eixo do pavimento e a média das bacias de deflexão calculadas por retroanálise.

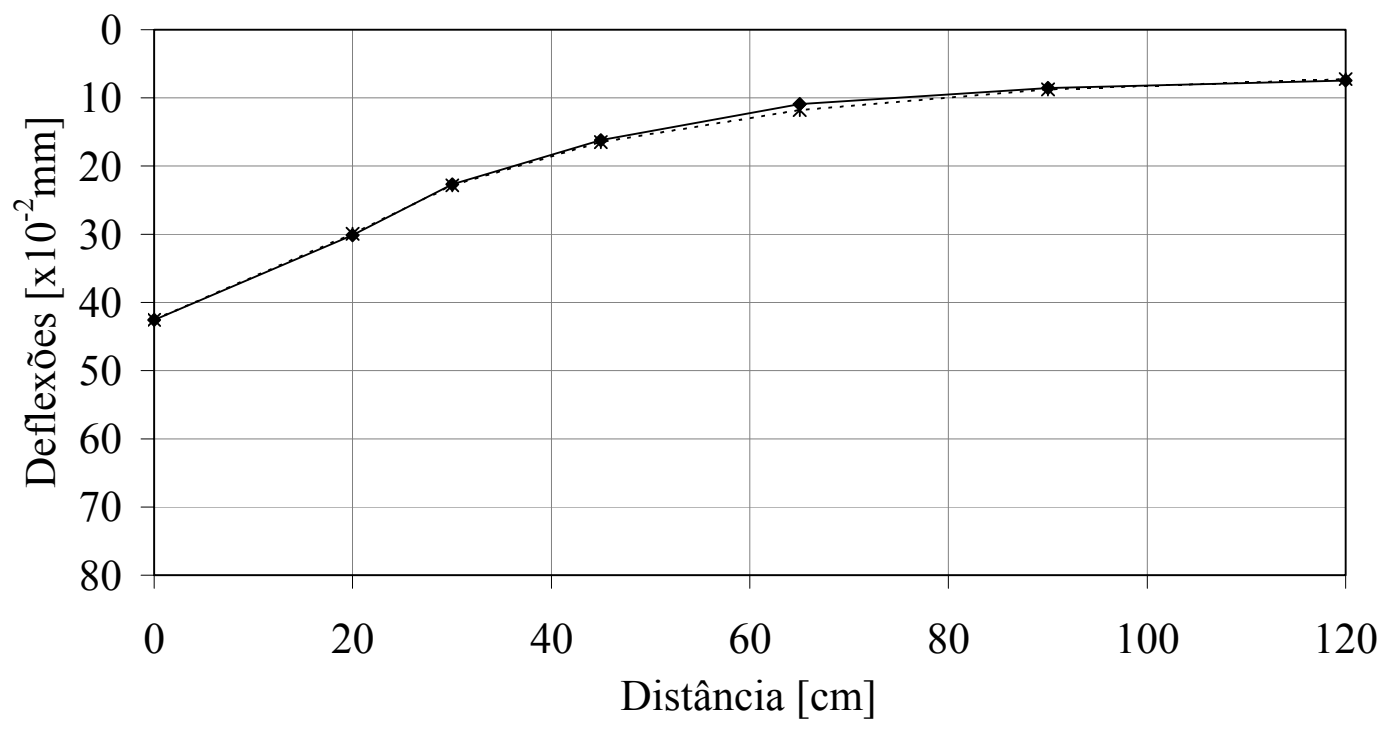

- Eixo - segmento homogêneo 1 -**•-Eixo - segmento homogêneo 1 - retroanálise

Figura 5.28: Análise da média das bacias de deflexão medidas no eixo e da média das bacias de deflexão calculadas por retroanálise para o segmento homogêneo 1

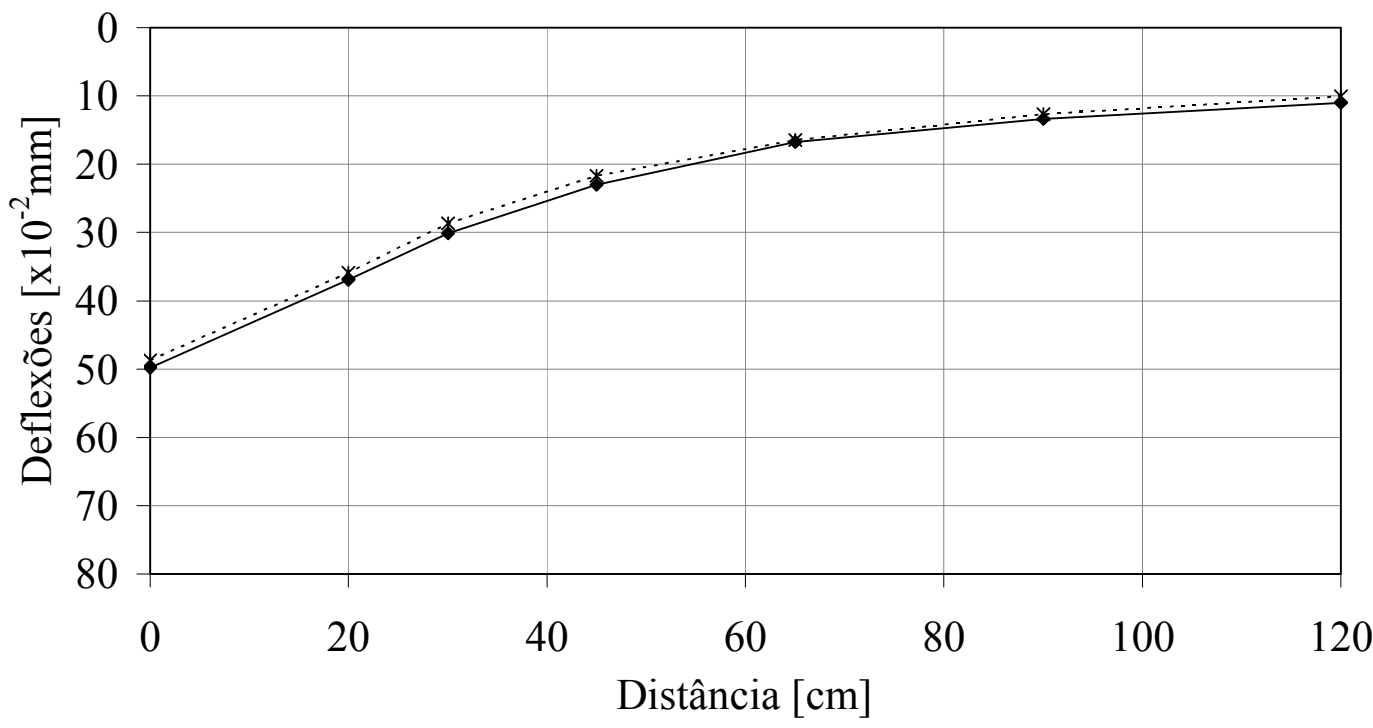

- - Eixo - segmento homogêneo 2 -**-・ Eixo - segmento homogêneo 2 - retroanálise

Figura 5.29: Análise da média das bacias de deflexão medidas no eixo e da média das bacias de deflexão calculadas por retroanálise para o segmento homogêneo 2 


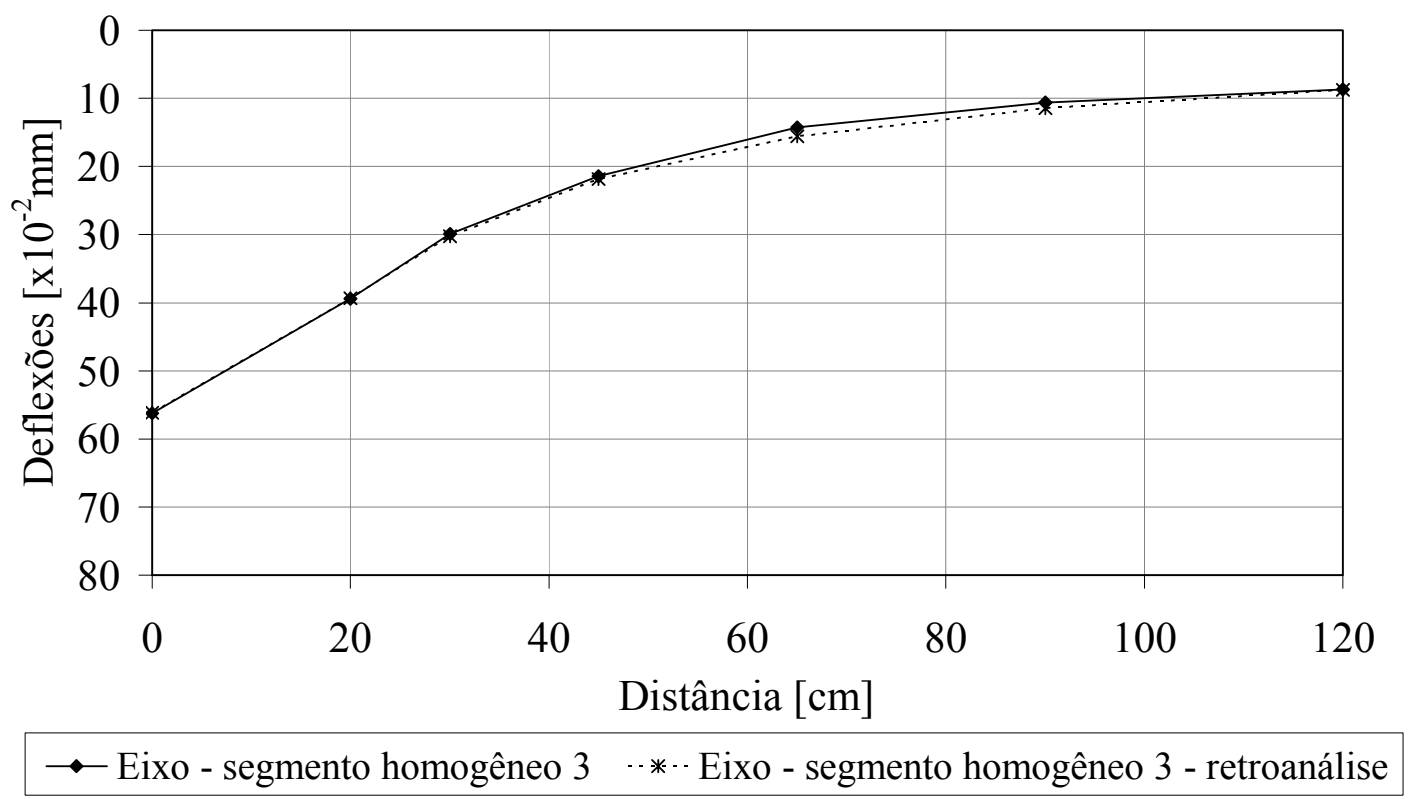

Figura 5.30: Análise da média das bacias de deflexão medidas no eixo e da média das bacias de deflexão calculadas por retroanálise para o segmento homogêneo 3

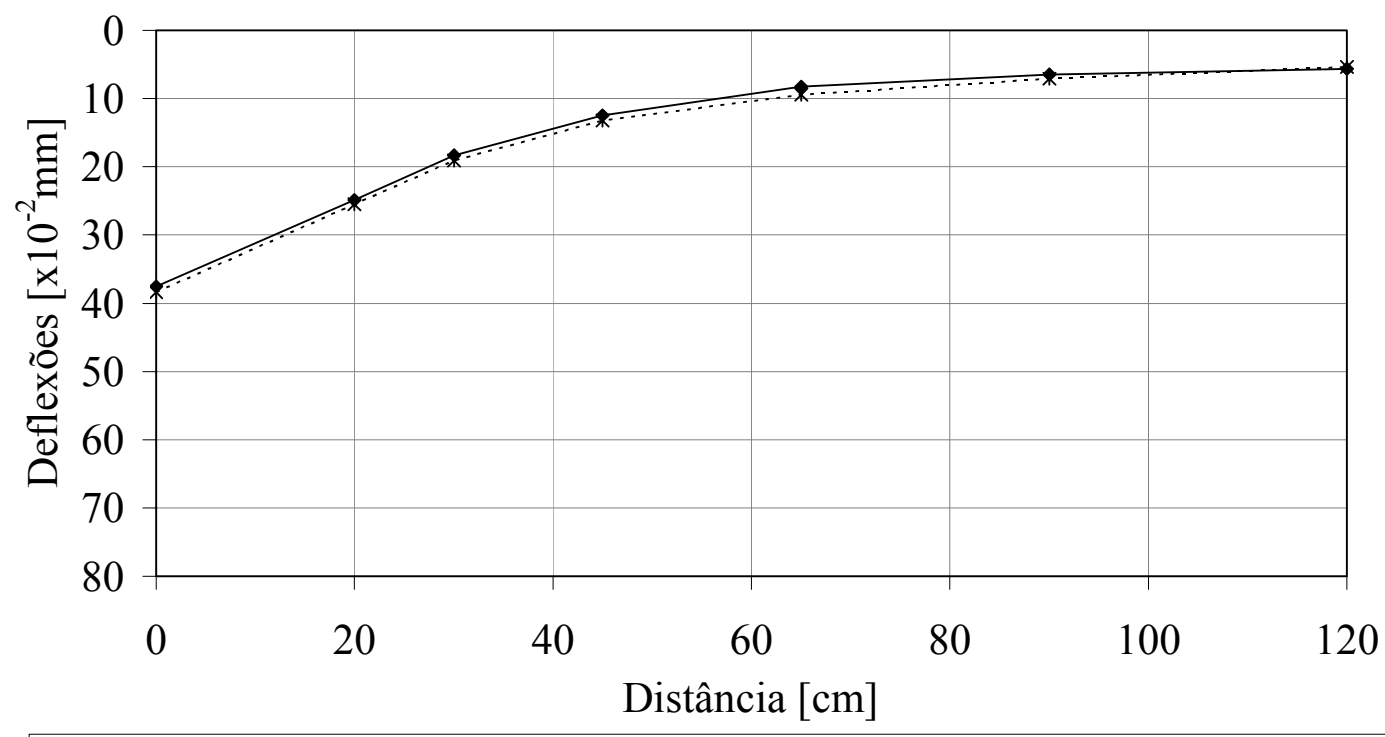

- - Eixo - segmento homogêneo $4 \quad \cdots * \cdots$ Eixo - segmento homogêneo 4 - retroanálise

Figura 5.31: Análise da média das bacias de deflexão medidas no eixo e da média das bacias de deflexão calculadas por retroanálise para o segmento homogêneo 4

Pelas figuras apresentadas é possível verificar que na média as bacias de deflexão calculadas por retroanálise ficaram semelhantes às bacias medidas em campo. Com relação aos módulos de resiliência, a Tabela 5.39 apresenta os valores obtidos para cada camada dos quatro segmentos homogêneos analisados (quatro seções-tipo). 
Tabela 5.39: Módulos de resiliência das camadas dos quatro segmentos analisados determinados por retroanálise das bacias de deflexão medidas no eixo do pavimento

\begin{tabular}{|c|c|c|c|c|c|}
\hline $\begin{array}{l}\text { Detalhe da } \\
\text { seção-tipo }\end{array}$ & $\begin{array}{l}\text { Segmento } \\
\text { homogêneo }\end{array}$ & Camada & $\begin{array}{c}\mathrm{M}_{\mathrm{R}} \\
{[\mathrm{MPa}]}\end{array}$ & $\begin{array}{l}\text { Desvio } \\
\text { padrão } \\
{[\mathrm{MPa}]}\end{array}$ & $\begin{array}{c}\text { Coef. } \\
\text { de } \\
\text { variação } \\
{[\%]}\end{array}$ \\
\hline @ Revestimento asfáltico & \multirow{5}{*}{1} & revestimento & 3000 & 306 & 10 \\
\hline$=\frac{\text { Base de brita groduoda }}{\text { simoles }}$ & & base & 336 & 39 & 12 \\
\hline$\simeq \begin{array}{c}\text { Sub-bose de agregodo } \\
\text { reciclado }\end{array}$ & & sub-base & 316 & 50 & 16 \\
\hline \multirow[t]{2}{*}{ 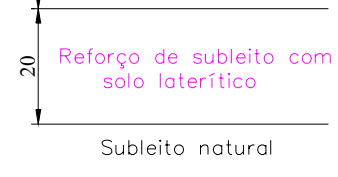 } & & $\begin{array}{l}\text { reforço de } \\
\text { subleito }\end{array}$ & 201 & 34 & 17 \\
\hline & & subleito & 156 & 27 & 17 \\
\hline I Revestimento asfáltico & \multirow{5}{*}{2} & revestimento & 3056 & 167 & 5 \\
\hline$=0$ & & base & 333 & 35 & 11 \\
\hline$\simeq \begin{array}{l}\text { Sub-bose de agregado } \\
\text { reciclado }\end{array}$ & & sub-base & 294 & 46 & 16 \\
\hline \multirow{2}{*}{$\begin{array}{c}\frac{1}{4} \\
\text { Subleito natural }\end{array}$} & & $\begin{array}{l}\text { reforço de } \\
\text { subleito }\end{array}$ & 177 & 33 & 19 \\
\hline & & subleito & 114 & 24 & 21 \\
\hline 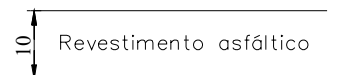 & \multirow{5}{*}{3} & revestimento & 2579 & 473 & 18 \\
\hline$=\begin{array}{c}\text { Bose de agregaco } \\
\text { recic ado }\end{array}$ & & base & 255 & 71 & 28 \\
\hline$=\begin{array}{l}\text { Sub-base de agregado } \\
\text { reciclado }\end{array}$ & & sub-base & 238 & 78 & 33 \\
\hline \multirow{2}{*}{$\therefore \mid \begin{array}{l}\text { Reforgo de subleito com } \\
\end{array}$} & & $\begin{array}{c}\text { reforço de } \\
\text { subleito }\end{array}$ & 176 & 54 & 31 \\
\hline & & subleito & 127 & 38 & 30 \\
\hline Revestimento asfático & \multirow{5}{*}{4} & revestimento & 2629 & 499 & 19 \\
\hline$=\quad \begin{array}{l}\text { Base de agregado } \\
\text { reciclado }\end{array}$ & & base & 336 & 73 & 22 \\
\hline$=\begin{array}{l}=\text { Sub bose de ogregado } \\
\text { recicicodo }\end{array}$ & & sub-base & 314 & 61 & 19 \\
\hline \multirow{2}{*}{ 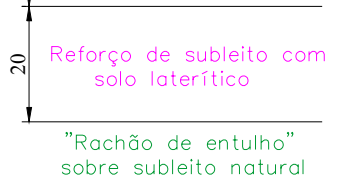 } & & $\begin{array}{c}\text { reforço de } \\
\text { subleito }\end{array}$ & 212 & 26 & 12 \\
\hline & & subleito & 193 & 24 & 12 \\
\hline
\end{tabular}


O módulo de resiliência do concreto asfáltico apresentou diferenças ao longo dos segmentos, em função do asfalto-borracha utilizado ser fornecido por diferentes companhias: os segmentos homogêneos 1 e 2 receberam asfalto-borracha da Greca Distribuidora de Asfalto Ltda. e as seções-tipo 3 e 4 da Petrobras Distribuidora S.A.

Pela retroanálise, verificou-se que para os segmentos homogêneos 1 e 2 os valores encontrados de módulo de resiliência para a brita graduada simples e para o agregado reciclado na camada de base são de $336 \mathrm{MPa}$ e $333 \mathrm{MPa}$, respectivamente. Este fato indica que o comportamento da brita graduada simples (segmento homogêneo 1) e do agregado reciclado (segmento homogêneo 2) são similares em campo. As camadas de sub-base de agregado reciclado para estes dois segmentos apresentaram valores também similares: 316MPa (segmento homogêneo 1) e 294MPa (segmento homogêneo 2). Os coeficientes de variação dos módulos das camadas de base e subbase destes dois segmentos são muitos semelhantes (cerca de 12\% para a base e $16 \%$ para a sub-base). O reforço de subleito composto por solo laterítico e o subleito dos segmentos homogêneos 1 e 2 tiveram módulos de resiliência altos, em relação ao esperado. Acredita-se que isto ocorreu em função ou do período de estiagem quando feito o levantamento deflectométrico ou que foi executada uma espessura maior de solo selecionado para o reforço de subleito que aquela de projeto. Pode ser ainda que tenha ocorrido durante a obra contaminação do subleito com o solo do subleito, o que implicou em uma melhora na resposta da estrutura.

Quanto ao segmento homogêneo 3, em conseqüência da compactação deficiente, o módulo de resiliência encontrado foi mais baixo. A camada de base ficou com $255 \mathrm{MPa}$ e a sub-base com $177 \mathrm{MPa}$. Acredita-se que se a compactação tivesse sido intensificada, acarretaria em uma redução nos valores de deformabilidade da estrutura. O reforço do subleito e o subleito apresentaram módulos elevados, em função do período de seca em que foi feito o ensaio com o FWD ou que a espessura de reforço de subleito esteja maior que a especificada no projeto.

No segmento homogêneo 4, o módulo de resiliência do agregado reciclado na camada de base ficou igual ao da brita graduada simples na base da seção-tipo 1, ou 
seja, 336MPa. A camada de sub-base também apresentou um módulo de resiliência elevado, 314MPa. Novamente é demonstrado o excelente comportamento do agregado reciclado, quando submetido a uma compactação eficiente. Para a camada de reforço de subleito foi obtido um módulo alto de 212MPa. Já a analise do subleito, fica comprometida, pois ela engloba o "rachão de entulho", por isso um módulo de $193 \mathrm{MPa}$.

Utilizando os valores apresentados na Tabela 5.39, calculou-se para cada camada do pavimento os módulos de resiliência máximos $\mathrm{M}_{\mathrm{R}}+\left(\mathrm{M}_{\mathrm{R}}\right.$ médio mais desvio padrão) e mínimos $\mathrm{M}_{\mathrm{R}^{-}}\left(\mathrm{M}_{\mathrm{R}}\right.$ médio menos desvio padrão). A Tabela 5.40 apresenta os valores obtidos.

Tabela 5.40: Variações dos módulos de resiliência de cada camada dos quatro segmentos homogêneos analisados determinados por retroanálise das bacias de deflexão medidas no eixo do pavimento

\begin{tabular}{|c|c|c|c|c|c|}
\hline \multirow{2}{*}{ Camada } & \multirow{2}{*}{$\begin{array}{c}\mathrm{M}_{\mathrm{R}} \\
{[\mathrm{MPa}]}\end{array}$} & \multicolumn{4}{|c|}{ Segmento homogêneo } \\
\cline { 3 - 6 } & $\mathrm{M}_{\mathrm{R}}^{+}$ & 3306 & 3222 & 3052 & 3128 \\
\hline \multirow{3}{*}{ Revestimento } & $\mathrm{M}_{\mathrm{R}^{-}}$ & 2694 & 2889 & 2106 & 2130 \\
\cline { 2 - 6 } Base & $\mathrm{M}_{\mathrm{R}^{+}}$ & 374 & 369 & 327 & 410 \\
\cline { 2 - 6 } & $\mathrm{M}_{\mathrm{R}^{-}}$ & 297 & 298 & 184 & 263 \\
\hline \multirow{3}{*}{ Sub-base } & $\mathrm{M}_{\mathrm{R}}+$ & 366 & 341 & 316 & 375 \\
\cline { 2 - 6 } & $\mathrm{M}_{\mathrm{R}^{-}}$ & 266 & 248 & 159 & 254 \\
\hline \multirow{2}{*}{$\begin{array}{c}\text { Reforço de } \\
\text { subleito }\end{array}$} & $\mathrm{M}_{\mathrm{R}^{+}}$ & 235 & 210 & 230 & 239 \\
\cline { 2 - 6 } & $\mathrm{M}_{\mathrm{R}^{-}}$ & 167 & 144 & 122 & 186 \\
\hline \multirow{2}{*}{ Subleito } & $\mathrm{M}^{+}$ & 183 & 138 & 165 & 217 \\
\cline { 2 - 6 } & $\mathrm{M}_{\mathrm{R}^{-}}$ & 129 & 90 & 89 & 169 \\
\hline
\end{tabular}

Observando os resultados apresentados na Tabela 5.40, é possível verificar que as variações nos módulos de resiliência na camada de base dos segmentos 1 e 2 são praticamente iguais. Assim, o agregado reciclado e a brita graduada simples apresentam comportamento mecânico similares. Os módulos de resiliência maiores do agregado reciclado na camada de base foram observados no segmento homogêneo 
4 e os menores no segmento homogêneo 3 , em função da melhora da resposta da estrutura com aplicação do "rachão de entulho" e da compactação deficiente no segmento homogêneo 3. 


\section{CONCLUSÕES, RECOMENDAÇÕES E SUGESTÕES}

São realizadas discussões e tecidas conclusões a partir dos resultados laboratoriais, observações e dados de campo, bem como da retroanálise das bacias de deflexão, procurando avaliar a aplicabilidade dos agregados reciclados de RCD como material de pavimentação e a possibilidade de inferência de comportamento de campo por meio dos ensaios de laboratório. É analisada a aplicabilidade da especificação brasileira de uso do agregado reciclado em pavimentação, enfocado os pontos essenciais para a avaliação do material e controle de obra, bem como sugerindo alterações ou complementações.

Por meio do estudo laboratorial com o agregado reciclado de Santo André, verificouse que este é um material do tipo misto. A análise da natureza dos materiais constituintes da fração graúda da amostra indicou como materiais predominantes os cimentícios, com 55,3\% (concretos e argamassas), e cerâmicos (telhas, tijolos, pisos e azulejos) com 29,4\%. Foi identificada ainda a presença de 1,6\% em massa de materiais indesejáveis de diferentes origens, estando de acordo com a NBR 15115 (ABNT, 2004). Muitos ensaios mostraram que a composição do agregado reciclado é um aspecto muito importante no seu emprego, pois influencia diretamente suas propriedades físicas. A predominância de materiais cimentícios, participando com mais de $50 \%$ do total, tem sido verificada por vários autores que trabalharam com os materiais reciclados da cidade de São Paulo.

A análise da massa específica dos grãos retidos na peneira $4,8 \mathrm{~mm}$ apresentou resultados muito variáveis de acordo com a natureza dos materiais. Os materiais de natureza cimentícia apresentam massa específica dos grãos de $2,75 \mathrm{~g} / \mathrm{cm}^{3}$ e aqueles de natureza cerâmica resultaram em $2,55 \mathrm{~g} / \mathrm{cm}^{3}$ (telhas e tijolos) e $2,50 \mathrm{~g} / \mathrm{cm}^{3}$ (pisos e azulejos). A massa específica dos agregados retidos na peneira de $4,8 \mathrm{~mm}$ foi de $2,69 \mathrm{~g} / \mathrm{cm}^{3}$, obtida por média ponderada. Os grãos passantes na peneira $4,8 \mathrm{~mm}$ apresentaram uma massa específica maior, $2,74 \mathrm{~g} / \mathrm{cm}^{3}$, em conseqüência da redução da porosidade pela britagem ou quebra nesta fração mais fina. 
A absorção de água dos grãos retidos na peneira 4,8mm também depende muito da natureza dos materiais, de forma similar à massa específica dos grãos desta mesma fração. Verificou-se que os materiais cerâmicos, como telhas e tijolos, apresentam uma absorção elevada, de aproximadamente 20,7\%. Os materiais cerâmicos com revestimentos impermeabilizantes, como pisos e azulejos, já apresentam absorção de 11,1\%. Os cimentícios apresentam-se com absorção de 11,5\%, mostrando ainda porosidade, porém inferior aos cerâmicos de telhas e tijolos. Para as britas, foram observadas absorções médias de 3,8\%, mostrando valores próximos aos obtidos normalmente com gnaisse ou granito britado, acrescido de pequena quantidade de argamassa cimentícia, que eleva um pouco a porosidade do conjunto. Assim, fica claro que quanto maior a concentração de materiais cerâmicos muito porosos, como telhas e tijolos, maior será a absorção do conjunto agregado reciclado, e menor a massa específica dos grãos. Estes resultados interferem diretamente na compactação.

A natureza dos materiais afeta ainda a forma dos agregados. De acordo com o estudo em laboratório, o agregado reciclado de Santo André apresentava antes da compactação $38,8 \%$ de grãos lamelares. A análise, considerando a natureza dos materiais, indicou que 79,5\% dos grãos lamelares são materiais cerâmicos (telhas, tijolos, pisos e azulejos). Já 55,7\% dos grãos com forma cúbica são compostos em sua grande maioria por materiais cimentícios (63,4\% do total desta natureza). Assim, quanto maior a concentração de materiais cerâmicos, maior é a tendência do agregado reciclado em apresentar grãos com forma lamelar; quanto maior a concentração de materiais cimentícios, maior é a tendência do agregado reciclado em apresentar grãos com forma cúbica. Esta característica é essencial para entendimento do arranjo dos grãos e do volume de vazios que este material apresentará em campo, após a compactação. O comportamento do material compactado é muito afetado pelas características deste arranjo, decorrente da forma e natureza dos constituintes.

Outro aspecto considerado neste trabalho foi o efeito da energia de compactação nas propriedades físicas e mecânicas do agregado reciclado. Em laboratório foi verificado que a graduação do material é alterada com a compactação, e depende ainda da energia aplicada. Após a compactação na energia intermediária, o material 
sofre quebras expressivas; com a energia modificada estas quebras continuam ocorrendo. As frações que sofreram maiores modificações foram aquelas entre as peneiras 25,0mm e 19,0mm, após o emprego da energia modificada. Com o aumento de energia intensificou-se a quebra mais significativa em peso dos agregados graúdos, com produção de agregados de menor dimensão e finos. A maior porcentagem de finos passantes da peneira $0,075 \mathrm{~mm}$ pode ser proveniente de todas as frações, que por atrito durante a compactação, mostram desprendimento desses finos. Em campo foi também verificada a modificação na graduação após a compactação. Os agregados reciclados fornecidos pela usina de Santo André apresentavam diferentes distribuições granulométricas iniciais. Contudo, observou-se que após a compactação em campo, os materiais tiveram uma tendência a tornaremse com distribuições granulométricas mais similares. Ou seja, o emprego de materiais que não são originalmente bem graduados leva a quebras significativas provocadas pelo menor entrosamento inicial, até chegarem a uma tendência à estabilização das rupturas dos agregados, por aumento da resistência ao cisalhamento do material obtido pela compactação. Assim, a compactação leva a uma produção maior de agregados de menor dimensão e de finos, tornando o material com tendência a ser mais bem graduado. Desta forma, a seleção ou recusa do material baseado essencialmente na granulometria original pode ser um critério equivocado. Evidentemente há de se limitar certas frações e distribuições que levariam a dificuldades de compactação e comportamento não adequado como material de pavimentação, porém deve-se estar atento às alterações granulométricas após a compactação.

O estudo em laboratório da influência da energia de compactação na forma do agregado mostrou que as principais alterações devem ocorrer já nos primeiros golpes. Após o emprego da energia intermediária, a porcentagem de grãos com forma cúbica aumentou (de 55,7\% para 68,0\%) e de grãos lamelares diminui (de $38,8 \%$ para 29,0\%). Com o emprego da energia modificada não foram observadas diferenças consideráveis em relação ao uso da energia intermediária. 
Estes fatos apresentados nos dois últimos parágrafos ilustram e esclarecem a importância de se controlar as propriedades físicas do material após a sua compactação. Inicialmente o agregado reciclado pode não estar de acordo com a especificação ou norma. Contudo após a sua compactação e a ocorrência das quebras, o material se transforma e pode passar a atendê-la, e vice-versa.

Os resultados obtidos com o programa experimental em laboratório e no campo indicaram a grande influência e importância da energia de compactação nas propriedades mecânicas do agregado reciclado. Por meio dos ensaios de compactação realizados em laboratório com o agregado reciclado de Santo André, foram obtidas curvas com o formato típico de sino. De acordo com a bibliografia consultada, é difícil obter uma curva de compactação típica para agregados reciclados. As umidades ótimas encontradas e pesos específicos aparentes secos máximos foram de $14,6 \%$ e $17,6 \mathrm{kN} / \mathrm{m}^{3}$, e $13,5 \%$ e $18,2 \mathrm{kN} / \mathrm{m}^{3}$ para as energias intermediária e modificada, respectivamente. Estes valores estão próximos ao verificado na literatura revisada para agregados mistos e ao obtido pela empresa fiscalizadora da obra para as diferentes amostras de agregados reciclados empregados em campo.

Por meio do controle de compactação em campo verificou-se que para as camadas executadas com agregado reciclado a variação de umidade de campo não ficou dentro dos limites da NBR 15115 (ABNT, 2004). Entretanto, este controle da umidade é questionável, já que a energia de compactação proporciona uma quebra no material, aumentando a quantidade de partículas mais finas e a superfície específica, fazendo com que o material demande mais água para continuar o processo de compactação. Além disso, apesar de ter sido atingido o grau de compactação de $100 \%$ para a camada de base com agregado reciclado, ficou claro pelo levantamento deflectométrico que a compactação foi deficiente em alguns locais. Este fato reforça que métodos de controle normalmente utilizados para materiais convencionais não são satisfatórios e/ou suficientes para o agregado reciclado de resíduo sólido da construção civil. Assim, para um material com grande variabilidade de natureza e de graduação original, a umidade e o peso específico aparente seco controlados em 
campo devem ser considerados meramente parâmetros indicativos, não limitantes, sendo importante e essencial a avaliação estrutural da camada do pavimento compactada. O grau de compactação e a umidade de campo não são propriedades índices e suficientes para inferência do comportamento do material em campo.

Foi possível observar a influência da energia de compactação nos ensaios de índice de suporte Califórnia. Houve um aumento considerável deste indicador de resistência com o aumento da energia empregada: o agregado reciclado de Santo André apresentou $73 \%$ para a energia intermediária e $117 \%$ para a energia modificada. Apesar dos resultados terem sido dispersivos (coeficiente de variação de 19\% e 22\%), Pinto (1964) observou coeficientes de variação entre 6,0\% e 33,9\% para materiais convencionais (solos e misturas granulares). Assim, o agregado reciclado está dentro desta faixa de variação. Novamente neste quesito, o ISC é apenas um indicativo de resistência e deve ser utilizado para estabelecer mínimos requeridos. Valores abaixo do especificado não podem indicar a presença excessiva de finos ou de finos expansivos. Porém, não se pode hierarquizar diretamente e simplesmente pelo ISC os materiais reciclados que apresentem ISC acima do mínimo requerido. A presença de agregados de grandes dimensões, com 50mm de diâmetro equivalente, por exemplo, pode induzir a valores de ISC elevados pela forma como é conduzido o ensaio, não refletindo propriamente que materiais com maiores ISC apresentarão menor deformabilidade ou maior rigidez, comparativamente a materiais com menores ISC, mas acima do mínimo.

Os ensaios de índice de suporte Califórnia realizados no controle tecnológico dos materiais de campo mostraram que algumas amostras de agregado reciclado não tiveram índice de suporte Califórnia de 60\%, valor indicado para serem empregados em camada de base, de acordo com a NBR 15115 (ABNT, 2004). Este fato pode ser explicado em função da presença de solo nos agregados reciclados provenientes de São Bernardo do Campo, com mais de $35 \%$ de materiais passantes na peneira $0,42 \mathrm{~mm}$. 
A realização do ensaio com o DCP iniciando a partir de diferentes camadas do pavimento permitiu controlar as espessuras das mesmas. Verificou-se que as espessuras das camadas do pavimento foram praticamente constantes ao longo do segmento do sistema viário da USP Leste analisado. As espessuras médias verificadas com o DCP foram próximas às espessuras projetadas. Com relação ao índice de penetração, foi possível verificar que o DPI médio (DCP Penetration Index) da camada de base é menor $(4,62 \mathrm{~mm} /$ golpe $)$ do que o DPI médio da camada de sub-base (5,53mm/golpe), embora ambas sejam constituídas de agregado reciclado. Este fato pode ser explicado em função da compactação ter sido mais eficiente na camada de base do que na sub-base, devido ao suporte oferecido pela camada subjacente. A camada de reforço de subleito, composta por solo laterítico, apresentou-se menos resistente que a camada de sub-base, pois seu DPI médio $(9,07 \mathrm{~mm} /$ golpe $)$ foi menor que o da camada de sub-base $(5,53 \mathrm{~mm} / \mathrm{golpe})$. O alto coeficiente de variação do DPI na camada de reforço de subleito indica que a eficiência da compactação não foi contínua ao longo da obra, pois a camada apresentava-se mais resistente em alguns locais, e menos resistente em outros, devido principalmente à capacidade de suporte do subleito, muito variável. O subleito do trecho com a seção-tipo 4 (Figura 3.2) foi analisado no estado natural, antes de receber o "rachão de entulho", e apresentou um DPI médio muito elevado $(115,22 \mathrm{~mm} /$ golpe), denotando a baixíssima capacidade de suporte do solo de fundação. No entanto, a escassez de locais ensaiados não permite garantir uma boa avaliação da heterogeneidade do solo ao longo de toda a extensão. O DCP é um ensaio que deveria ser empregado para a avaliação de subleitos e mesmo de camadas de solo, tanto para projeto como para controle.

Com relação ao índice de suporte Califórnia mínimo obtido pela correlação com o DPI do método USACE (1992), o agregado reciclado não atingiu valor maior que $60 \%$ na camada de base (52\%). Este trecho, onde foram realizados os levantamentos sobre a camada de base, corresponde ao segmento homogêneo 3, que teve uma compactação deficiente, como constatado pelo levantamento deflectométrico. Embora não se tenha feito uma programação de ensaios para relacionar o ISC com o DPI, os resultados observados mostram que o desenvolvimento de correlações do 
ISC com DPI pode levar a bons resultados para o controle de compactação em campo. A introdução de controle de deflectométrico ou de rigidez não destrutivo seria o mais indicado pela facilidade de realização de uma bateria de ensaios e da correlação direta com o comportamento. Acredita-se que a introdução no Brasil de ensaios do tipo LWD (Light Weight Deflectometer) seja indicada para este material.

O levantamento deflectométrico feito com o equipamento FWD sobre a camada de rolamento com concreto asfáltico, permitiu verificar que a bacia de deflexão obtida para o trecho com brita graduada simples na camada de base (segmento homogêneo 1) ficou semelhante à bacia obtida para o segmento com agregado reciclado (segmento homogêneo 2) como material de base. Os raios de curvatura encontrados para os dois trechos reforçam que o desempenho do agregado reciclado é similar ao material convencional, no caso a brita graduada simples. Com a retroanálise foi possível verificar que os valores de módulo de resiliência obtidos para a brita graduada simples (segmento homogêneo 1) e para o agregado reciclado (segmento homogêneo 2) na camada de base foram praticamente idênticos, de $336 \mathrm{MPa}$ e $333 \mathrm{MPa}$, respectivamente.

No terceiro segmento (segmento homogêneo 3), onde a compactação do agregado reciclado foi menos eficiente, foi observada uma deflexão mais elevada e uma redução no raio de curvatura. O módulo de resiliência obtido por retroanálise para o agregado reciclado na camada de base nestas condições de estado foi de $255 \mathrm{MPa}$. Acrescente-se que neste trecho há locais onde o material de base continha mais finos que os demais. Este fato pode ter levado à redução da eficiência da compactação e de módulo de resiliência.

O quarto segmento (segmento homogêneo 4) apresentou a bacia média com os menores valores de deflexão. Apesar do pavimento da seção-tipo 4 ter a mesma estrutura da seção-tipo 3, a presença do "rachão de entulho" sobre o subleito de solo mole reduziu a deformabilidade das camadas. O "rachão de entulho" possibilitou uma melhor compactação das camadas de reforço de subleito, e por conseqüência as de sub-base e de base. O módulo de resiliência do agregado reciclado na camada de 
base foi igual ao da brita graduada simples no segmento homogêneo 1, de 336MPa. A intensificação da compactação resultou em uma redução nos valores de deformabilidade da estrutura como um todo.

Em laboratório, os ensaios de módulo de resiliência apresentaram uma melhora no comportamento do agregado reciclado de Santo André com a compactação na energia modificada. $\mathrm{O}$ módulo de resiliência para a energia intermediária variou de 160 a 440MPa, e para a energia modificada, ficou entre 200 a 500MPa, de acordo com o estado de tensões durante o ensaio. Observou-se ainda que apesar do agregado reciclado estudado em laboratório nesta pesquisa apresentar coesão, devido à presença de finos e de uma possível cimentação entre as partículas pela presença de atividade pozolânica, o módulo de resiliência é ainda bastante dependente da tensão de confinamento. Este fato demonstra que a coesão é um fator que colabora na resistência deste material, mas não prepondera na resistência ao cisalhamento. Os resultados de módulo de resiliência obtidos em laboratório foram muito similares aos valores obtidos em campo pela retroanálise das bacias de deflexão, nas condições de estado de compactação e de tensões aplicadas. No caso de agregados reciclados de $\mathrm{RCD}$, os ensaios laboratoriais predizem com bastante fidelidade o comportamento em campo.

Os ensaios triaxiais com cargas repetidas conduzidos em laboratório indicaram uma influência da energia de compactação na resistência à deformação permanente do agregado reciclado. Para um mesmo estado de tensões $\left(\sigma_{d} / \sigma_{3}=6,0\right)$, observou-se uma maior resistência à deformação permanente para o agregado reciclado compactado na energia modificada. Quando submetido a diferentes estados de tensões, o agregado reciclado compactado na energia modificada apresentou menores deformações permanentes para relações $\sigma_{d} / \sigma_{3}$ menores, como era de se esperar. Com relação à brita graduada na mesma granulometria obtida após a compactação do agregado reciclado, verificou-se uma deformação maior na brita, para o nível de tensões $\sigma_{\mathrm{d}} / \sigma_{3}=2,0$. Quando comparado com outros materiais disponíveis na literatura, como laterita e brita na faixa A do DNER, o agregado reciclado apresentou deformação permanente inferior, mesmo quando submetido a um nível de tensões 
mais elevado. Este fato pode ser explicado em função da coesão e pelo elevado ângulo de atrito, devido à elevada abrasão superficial destes grãos combinada ao entrosamento entre os agregados de diferentes dimensões após quebra, contribuindo para o aumento da resistência à deformação permanente. Observe-se que passa a ser essencial nos resultados de deformação permanente a natureza, a forma dos agregados, o arranjo dos grãos e a própria distribuição granulométrica após quebra pela compactação, neste caso importantíssimo aspecto para as propriedades mecânicas dos agregados reciclados. Todos os estudos indicam a necessidade de compactação na energia modificada dos agregados reciclados, o que deveria ser considerado em uma futura revisão da NBR 15115 (ABNT, 2004).

Ao aplicar a teoria do shakedown foi possível verificar que a maioria dos corpos-deprova apresentou uma resposta intermediária, estando no limite B. Durante os primeiros ciclos de carregamento a deformação permanente é elevada, mas decresce com as sucessivas aplicações de carga, até ter um aumento constante. Apenas um corpo-de-prova apresentou uma resposta elástica, estando no limite A do shakedown $\left(\sigma_{\mathrm{d}} / \sigma_{3}=2,0\right)$, enquanto um corpo-de-prova teve um comportamento intermediário entre nível B e C $\left(\sigma_{d} / \sigma_{3}=6,7\right)$ onde poderia ter ocorrido a ruptura, caso o ensaio fosse levado a um número maior de ciclos. A estabilização de comportamento à deformação permanente, caracterizada pelo estado A, pode ser alcançada limitandose o estado de tensões - ou seja, empregando este material em camadas de sub-base ou ainda subjacentes - ou aumentando-se a energia de compactação.

\section{Recomendações:}

Com relação ao dimensionamento de estruturas com agregados reciclados, o índice de suporte Califórnia não é o melhor parâmetro para ser utilizado. Seus valores são muito variáveis, principalmente quando o material contém grande quantidade da fração pedregulho. Contudo, o ISC é um ensaio muito difundido no meio rodoviário, o que colabora para o emprego do agregado reciclado em pavimentos. Assim, paralelo à determinação do ISC, é interessante sempre determinar o módulo de resiliência do material e fazer uma análise mecanicista por método teórico. 
A variabilidade dos agregados reciclados é uma questão que muitas vezes dificulta o seu emprego em camadas de pavimentos. No entanto, esta pesquisa mostrou que mesmo este material tendo grande potencial de variação nas suas propriedades físicas, controlando a execução é possível ter um pavimento com bom desempenho. É indispensável o uso de energia modificada.

As normas e as especificações para uso de agregado reciclado em camada de pavimentos devem compreender a determinação da composição do agregado reciclado. Este fator é importante, pois permite estimar propriedades físicas do material, como por exemplo, se apresentará maior índice de vazios ou se terá tendência a apresentar partículas lamelares. Além disso, as propriedades físicas do agregado reciclado devem ser controladas após a compactação. Os responsáveis pela fiscalização devem estar sempre atentos à suscetibilidade de alterações dos agregados reciclados com a compactação. A repetibilidade de ensaios do controle tecnológico deve ser respeitada, caso contrário não é possível controlar um material neste nível de potencial de variabilidade.

Como constatado também por Molenaar e van Niekerk (2002), o comportamento mecânico da estrutura depende diretamente da compactação eficiente do agregado reciclado. Ainda que a graduação e a composição muitas vezes sejam parâmetros de difícil controle, a compactação eficiente é possível de ser realizada e fiscalizada a um custo baixo. A compactação eficiente deve ser um aspecto de fundamental importância no controle tecnológico, pois as quebras devem ocorrer durante o processo construtivo e não ao longo da vida útil do pavimento.

Como o controle de compactação em campo por métodos tradicionais como o frasco de areia, pode não se apresentar satisfatório para agregados reciclados, é importante controlar a deformabilidade da estrutura. Pode ser empregado o LWD, ou a viga Benkelman ou ainda o FWD. Outro método de controle indicado é o DCP para estimar o índice de suporte Califórnia em campo, já que este parâmetro é utilizado no projeto de camadas de pavimentos com agregados reciclados. De acordo com a literatura revisada, o modelo de correlação do USACE (1992) é empregado para 
diferentes materiais, no entanto, é importante desenvolver pesquisas para determinar modelos mais apropriados para agregados reciclados.

Pelos resultados de módulo de resiliência observados em laboratório neste trabalho, na literatura revisada e pelo obtido por retroanálise, o módulo de resiliência de agregados reciclados do tipo misto está em torno de $200 \mathrm{MPa}$ a $300 \mathrm{MPa}$. Este valor de módulo é comumente encontrado para britas graduadas simples. No entanto, um fato preocupante é a deformação permanente deste material. Neste trabalho verificou-se que não houve uma estabilização da deformação permanente com o tempo, apesar de apresentar uma tendência a um aumento pequeno e constante. Assim, para emprego em camada de base, o tráfego deve ser conhecido e é aconselhável a verificação da deformação permanente para as condições em campo. Para uso em camadas de sub-base, o agregado reciclado é uma boa alternativa, garantindo uma redução da deformabilidade da estrutura quando bem compactado.

Sugestões para trabalhos futuros:

- Continuar o monitoramento e a avaliação estrutural do pavimento da USP Leste ao longo do tempo;

- Verificar a influência do aumento da concentração de materiais cerâmicos (telhas, tijolos, pisos e azulejos) nas propriedades mecânicas do agregado reciclado;

- Verificar a influência da redução da dimensão característica máxima do agregado reciclado;

- Continuar o estudo da deformação permanente de agregados reciclados, verificando se ocorre quebra de partículas (alterações na granulometria) com o aumento do nível de tensões e do número de repetições do carregamento;

- Analisar a deformação permanente utilizando a teoria do shakedown submetendo os corpos-de-prova a repetições de carregamento maiores;

- Definição de controles tecnológicos de materiais e de execução mais adequados para a construção de vias com agregados reciclados. 


\section{REFERÊNCIAS BIBLIOGRÁFICAS}

ABU-FARSAKH, M. Y.; NAZZAL, M. D.; ALSHIBLI, K; SEYMAN, E. Application of dynamic cone penetrometer in pavement construction control. Transportation Research Record, Washington, n.1913, p.53-61, 2005.

AMERICAN SOCIETY FOR TESTING AND MATERIALS. D 6951 - 03: Standard test method for use of the Dynamic Cone Penetrometer in shallow pavement applications. West Conshohocken, Pennsylvania, 2003.

ASSOCIAÇÃO BRASILEIRA DE NORMAS TÉCNICAS. NBR 7181: Solo análise granulométrica - Método de ensaio. Rio de Janeiro, 1984.

. NBR 6508: Grãos de solo que passam na peneira de $4,8 \mathrm{~mm}$ - determinação da massa específica. Rio de Janeiro, 1984.

_. NBR 6458: Grãos de pedregulho retidos na peneira de 4,8 mm - determinação da massa específica, da massa específica aparente e da absorção de água. Rio de Janeiro, 1984.

- NBR 6457: Amostras de solo - preparação para ensaios de compactação e ensaios de caracterização. Rio de Janeiro, 1986.

_. NBR 7182: Solo - ensaio de compactação. Rio de Janeiro, 1986. $\overline{19} 89$.

. NBR 6954: Lastro Padrão: determinação da forma do material. Rio de Janeiro,

_. NBR 10004: Resíduos Sólidos - Classificação. Rio de Janeiro, 2004.

. NBR 10005: Lixiviação de resíduos - Procedimento para obtenção de extrato lixiviado de resíduos sólidos. Rio de Janeiro, 2004.

. NBR 10006: Solubilização de resíduos - Procedimento para obtenção de extrato solubilizado de resíduos sólidos. Rio de Janeiro, 2004.

_. NBR 10007: Amostragem de resíduos. Rio de Janeiro, 2004.

. NBR 15113: Resíduos sólidos da construção civil e resíduos inertes - Aterros Diretrizes para projeto, implantação e operação. Rio de Janeiro, 2004.

_. NBR 15114: Resíduos sólidos da construção civil e resíduos inertes - Áreas de reciclagem - Diretrizes para projeto, implantação e operação. Rio de Janeiro, 2004.

. NBR 15115: Agregados reciclados de resíduos sólidos da construção civil Execução de camadas de pavimentação - Procedimentos. Rio de Janeiro, 2004. 
. NBR 15116: Agregados reciclados de resíduos sólidos da construção civil Utilização em pavimentação e preparo de concreto sem função estrutural Requisitos. Rio de Janeiro, 2004.

ÂNGULO, S. C.; KAHN, H.; JOHN, V. M.; ULSEN, C. Metodologia de caracterização de resíduos de construção e demolição. In: SEMINÁRIO DESENVOLVIMENTO SUSTENTÁVEL E A RECICLAGEM NA CONSTRUÇÃO CIVIL, 6., São Paulo, 2003. Anais. São Paulo: IBRACON, 2003.

ÂNGULO, S. C. Caracterização de agregados de resíduos de construção e demolição reciclados e a influência de suas características no comportamento de concretos. Tese (Doutorado). Escola Politécnica, Universidade de São Paulo. São Paulo, 2005.

ARM, M. Self-cementing properties of crushed demolished concrete in unbound layers: results from triaxial tests and field tests. Waste Management and Research, v.21, p.235-239, 2001.

BENNERT, T.; PAPP JR., W. J.; MAHER, A.; GUCUNSKI, N. Utilization of construction and demolition debris under traffic-type loading in base and subbase applications. Transportation Research Record, Washington, n.1714, p.33-39, 2000 .

BERNUCCI, L. L. B. Considerações sobre o dimensionamento de pavimentos utilizando solos lateríticos para rodovias de baixo volume de tráfego. 1995. 237p. Tese (Doutorado) - Escola Politécnica, Universidade de São Paulo. São Paulo, 1995.

BLANKENAGEL, B. J.; GUTHRIE, W. S. Laboratory characterization of recycled concrete for use as pavement base material. Transportation Research Record, Washington, n.1952, p.21-27, 2006.

BODI, J.; BRITO FILHO, J. A; ALMEIDA, S Utilização de Entulho de Construção Civil Reciclado na Pavimentação Urbana. In: REUNIÃO ANUAL DE PAVIMENTAÇÃO, 29., Cuiabá, 1995. Anais. Rio de Janeiro: ABPv, 1995. p.409436.

CARNEIRO, A. P.; BURGOS, P. C; ALBERTE, E. P. V. Uso do agregado reciclado em camadas de base e sub-base de pavimentos. Projeto Entulho Bom. Salvador: EDUFBA / Caixa Econômica Federal, 2001.pg 190-227.

CHEN, D.; WANG, J.; BILYEU, J. Application of dynamic cone penetrometer in evaluation of base and subgrade layers. Transportation Research Record, Washington, n.1764, p.1-10, 2001.

CHINI, A. R.; KUO, S.; ARMAGHANI, J. M.; DUXBURY, J. P. Test of recycled concrete aggregate in accelerated test track. Journal of Transportation Engineering. Reston, Virginia, v.127, n.6, p.486-492, 2001. Disponível em: $<$ http://ascelibrary.aip.org/getpdf/servlet/GetPDFServlet?filetype=pdf\&id=JTPEDI0 


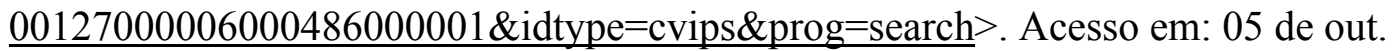
2006

CONCREMAT ENGENHARIA. Relatórios técnicos de acompanhamento. Obra: Universidade de São Paulo - USP Leste, 2005/2006.

CONSELHO NACIONAL DO MEIO AMBIENTE. Resolução CONAMA n $\mathbf{3 0 7}$, de 5 de julho de 2002. Disponível em:

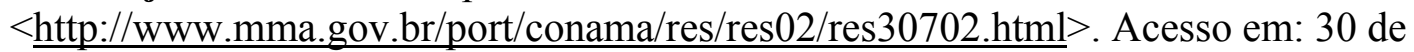
jun. 2006

COPPEAD. Índices de transporte rodoviário. Instituto de Pós-graduação e Pesquisa em Administração, Universidade Federal do Rio de Janeiro. Rio de Janeiro, 2007. Disponível em:

$<$ http://www.centrodelogistica.com.br/new/_IndicesRodoviariosV7.pdf $>$. Acesso em: 05 de mai. 2007

DEPARTAMENTO DE ESTRADAS DE RODAGEM. DER M 28-61:

Determinação do teor de umidade de solos pelo fogareiro. São Paulo, 1961.

DEPARTAMENTO NACIONAL DE ESTRADAS DE RODAGEM. Manual de reabilitação de pavimentos asfálticos. Ministério dos Transportes. Rio de Janeiro, 1998.

. DNER ME 049/94: Solo - determinação do índice de suporte Califórnia utilizando amostras não trabalhadas. Rio de Janeiro, 1994.

. DNER ME 092/94: Determinação da massa específica aparente "in situ" com emprego do frasco de areia. Rio de Janeiro, 1994.

. DNER ME 131/94: Solos - Determinação do módulo de resiliência. Rio de Janeiro, 1994.

. DNER PRO 011/79: Avaliação estrutural de pavimentos flexíveis: procedimento B. Rio de Janeiro, 1979.

. DNER PRO 269/94: Projeto de restauração de pavimentos flexíveis TECNAPAV. Rio de Janeiro, 1994.

. DNER PRO 273/96: Determinação de deflexões utilizando deflectômetro de impacto tipo "Falling Weight Deflectometer (FWD)". Rio de Janeiro, 1996.

DEPARTAMENTO NACIONAL DE INFRA-ESTRUTURA DE TRANSPORTES. Manual de Pavimentação. 3ed. Rio de Janeiro, 2006.

DEPARTAMENTO NACIONAL DE PRODUÇÃO MINERAL. Sumário Mineral 2005. Brasília. 2005. 
ENVIRONMENTAL PROTECTION AGENCY (EPA). Characterization of building-related construction and demolition debris in the United States. United States, 1998. 100p. Disponível em:

$<$ http://www.epa.gov/epaoswer/hazwaste/sqg/c\&d-rpt.pdf $>$

EUROPEAN COMISSION (EC). Management of construction and demolition waste. 2000. Disponível em:

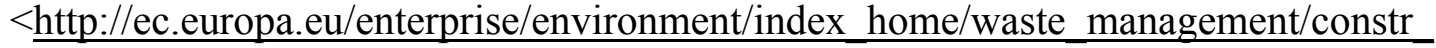
dem waste 000404.pdf $>$

FEDERAL HIGHWAY ADMINISTRATION. FHWA-RD-97-148: User guidelines for waste and byproduct materials in pavement construction. Department of Transportation. Washington, 1997. Disponível em:

$<$ http://www.tfhrc.gov/hnr20/recycle/waste/begin.htm>. Acesso em: 02 de fev. 2007

FERNANDES, C. G. Caracterização mecanística de agregados reciclados de resíduos de construção e demolição dos municípios do Rio de Janeiro e de Belo Horizonte para uso em pavimentação. 2004. 109p. Dissertação (Mestrado) Coordenação dos Programas de Pós-graduação de Engenharia, Universidade Federal do Rio de Janeiro (COPPE-UFRJ). Rio de Janeiro, 2004.

FRAZÃO, E. B. Tecnologia de rochas na construção civil. Associação Brasileira de Geologia de Engenharia e Ambiental. São Paulo, 2002.

FROTA, C. A. da; MENTA, C. de O.; NUNES, F. R. G. Utilização de entulho reciclado em misturas asfálticas para a região de Manaus-AM. In: REUNIÃO DE PAVIMENTAÇÃO URBANA, 12., Aracaju, 2003. Anais. Rio de Janeiro: ABPv, 2003. 1 CD-ROM.

GUIMARÃES, A. C. R. Estudo de deformação permanente em solos e a teoria do shakedown aplicada a pavimentos flexíveis. 2001. 173p. Dissertação (Mestrado) Coordenação dos Programas de Pós-graduação de Engenharia, Universidade Federal do Rio de Janeiro (COPPE-UFRJ). Rio de Janeiro, 2001.

HUANG, Y. H. Pavement analysis and design. $2^{\text {nd }}$ Edition, Prentice Hall, Upper Saddle River, 2004.

HILL, A. R.; DAWSON, A.R.; MUNDY, M. Utilization of aggregate materials in road construction and bulk fill. Journal of Resources, Conservation \& Recycling, v.32, p.305-320, 2001.

INTERGOVERNMENTAL PANEL ON CLIMATE CHANGE (IPCC). Summary for Policymakers. Fourth Assessment Report, Working Group III.Genebra, Suíça, 2007. Disponível em:

$<$ http://arch.rivm.nl/env/int/ipcc/docs/FAR/Approved\%20SPM\%20WGIII_0705rev5 .pdf >. Acesso em: 18 de mai. 2007 
JOHN, V. M.; ROCHA, J. C. Utilização de resíduos na construção habitacional. Coleção Habitare, v.4. ANTAC, Porto Alegre, 2003.

KLEYN, E. G. The use of the dynamic cone penetrometer (DCP). Transvaal Roads Department. Report n.2/74, 1975.

KUO, S.; MAHGOUB, H. S.; ORTEGA, J. E. Use of recycled concrete made with Florida limestone aggregate for a base course in flexible pavement. Final Report, Florida Department of Transportation. Orlando, Florida, 2001.

KUO, S.; MAHGOUB, H. S.; NAZEF, A. Investigation of recycled concrete made with limestone aggregate for a base course in flexible pavement. Transportation Research Record, Washington, n.1787, p.99-108, 2002.

KRYCKYJ, P. R.; TRICHÊS, G. Use of civil construction waste in urban pavements: a feasibility study. In: INTERNATIONAL SYMPOSIUM ON ENVIRONMENTAL GEOTECHNOLOGY AND GLOBAL SUSTAINABLE DEVELOPMENT, 5. Belo Horizonte, 2000. Anais.1 CD-ROM.

LEKARP, F.; RICHARDSON, I. R.; DAWSON, A. Influences on permanent deformation behavior of unbound granular materials. Transportation Research Record, Washington, n.1547, p.68-75, 1996.

LEVY, S. M. Contribuição ao estudo da durabilidade de concretos, produzidos com resíduos de concreto e alvenaria. 2001. 194p. Tese (Doutorado) - Escola Politécnica, Universidade de São Paulo. São Paulo, 2001.

LIMA, L. C. O ensaio DCP aplicado no controle de qualidade de compactação de obra viárias executadas com solos lateríticos de textura fina. 2000. 146p. Dissertação (Mestrado) - Pós-graduação em Engenharia de Infra-estrutura Aeronáutica, Instituto Tecnológico de Aeronáutica. São José dos Campos, 2000.

LIMA, J. A. R. Proposição de diretrizes para produção e normalização de resíduo de construção reciclado e de suas aplicações em argamassas e concretos. 1999. 240p. Dissertação (Mestrado) - Escola de Engenharia de São Carlos, Universidade de São Paulo. São Carlos, 1999.

LIVNEH, M. In-situ CBR testing by indirect methods. In: INTERNATIONAL CONFERENCE ON SOIL MECHANICS AND FOUNDATION ENGINEERING, 12., Rio de Janeiro, 1989. Anais. A.A.Balkema/Rotterdam/Brooffield, volume 1, 1989, p.267-270.

MALYSZ, R. Comportamento mecânico de britas empregadas em pavimentação. 2004. 166p. Dissertação (Mestrado) - Programa de Pós-graduação em Engenharia Civil, Universidade Federal do Rio Grande do Sul. Porto Alegre, 2004.

MEDINA, J. Mecânica dos pavimentos. Rio de Janeiro: UFRJ, 1997. 380p. 
MENDES, T. A.; REZENDE, L. R.; OLIVEIRA, J. C.; GUIMARÃES, R. C., CARVALHO, J. C.; VEIGA, R. Parâmetros de uma pista experimental executada com entulho reciclado. In: REUNIÃO ANUAL DE PAVIMENTAÇÃO, 35., Rio de Janeiro, 2004. Anais. Rio de Janeiro: ABPv, 2004. 1 CD-ROM.

MINNESOTA DEPARTMENT OF TRANSPORTATION. User Guide of the Dynamic Cone Penetrometer. Office of Minnesota Road Research, Mn/ROAD. Saint Paul, Minnesota, 1996. Disponível em:

$<$ http://mnroad.dot.state.mn.us/research/dcp/user_guide.pdf $>$. Acesso em: 10 de nov. 2006

MOLENAAR, A. A. A.; VAN NIEKERK, A. A. Effects of gradation, composition, and degree of compaction on the mechanical characteristics of recycled unbound materials. Transportation Research Record, Washington, n.1787, p.73-82, 2002.

MONISMITH, C. L.; OGAWA, N.; FREEME, C. R. Permanent deformation characteristics of subgrade soils due to repeated load. Transportation Research Record, Washington, n.537, p.1-17, 1975.

MOREIRA, J. F.; DIAS, J. F.; REZENDE, M. E. B. Utilização de resíduos de construção e demolição em base de pavimentos na cidade de Uberlândia-MG. In: REUNIÃO DE PAVIMENTAÇÃO URBANA, 13., Maceió, 2006. Anais. Rio de Janeiro: ABPv, 2006. 1 CD-ROM.

MOTTA, R. S. Estudo laboratorial de agregado reciclado de resíduo sólido da construção civil para aplicação em pavimentação de baixo volume de tráfego. Dissertação (Mestrado). Escola Politécnica, Universidade de São Paulo. São Paulo, 2005.

MOTTA, L. M. G.; FERNADES, C. Utilização de resíduo sólido da construção civil em pavimentação urbana. In: REUNIÃO DE PAVIMENTAÇÃO URBANA, 12., Aracaju, 2003. Anais. Rio de Janeiro: ABPv, 2003.

NATAATMADJA, A.; TAN, Y. L. Resilient response of recycled concrete road aggregates. Journal of Transportation Engineering. Reston, Virginia, v.127, n.5, p.450-453, 2001. Disponível em:

$<$ http://ascelibrary.aip.org/getpdf/servlet/GetPDFServlet?filetype=pdf\&id=JTPEDI0

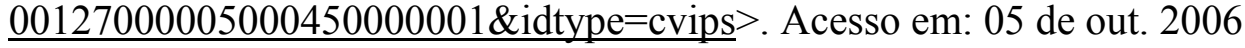

O'MAHONY, M. M.; MILLIGAN, G. W. E. Use of recycled materials in subbase layers. Transportation Research Record, Washington, n.1310, p.73-80, 1991.

PINTO, C. S. Estudo da dispersão do ensaio C.B.R. Boletim Técnico da Associação Brasileira de Pavimentação: n.6. Rio de Janeiro, 1964.

PINTO, C. S. Curso básico de mecânica dos solos em 16 aulas. Oficina de Textos. São Paulo, 2000. 
PINTO, S.; PREUSSLER, E.S. Pavimentação rodoviária: Conceitos

fundamentais sobre pavimentos flexíveis. $2^{\mathrm{a}}$ Edição, Editora Copiarte, Rio de Janeiro, 2002.

PINTO, T. P. Metodologia para a gestão diferenciada de resíduos sólidos da construção urbana. 1999. 189p. Tese (Doutorado) - Escola Politécnica, Universidade de São Paulo. São Paulo, 1999.189p.

PINTO, T. P. Projeto e implantação da usina de reciclagem de entulho. In:

SEMINÁRIO DE RESÍDUOS SÓLIDOS URBANOS. Lixo e Entulho - Recursos Recicláveis. Anais. Publicado por Japan Internation Cooperation Agency. Atibaia, 2003.

POON, C. S.; CHAN, D. Feasible use of recycled concrete aggregates and crushed clay brick as unbound road sub-base. Construction and Building Materials, v.20, p.578-585, 2006. Disponível em: $<$ http://www.elsevier.com $>$. Acesso em: 02 de ago. 2006

PREFEITURA DO MUNICÍPIO DE SÃO PAULO. São Paulo em números. São Paulo. 1998. Disponível em:

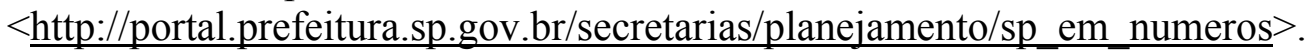

Acesso em: 20 de nov. 2006.

. PMSP/SP IP-08: Análise mecanicista à fadiga de estruturas de pavimento. São Paulo. 2002. Disponível em:

$<$ http://ww2.prefeitura.sp.gov.br//arquivos/secretarias/infraestruturaurbana/normas t ecnicas de pavimentacao/ip08.pdf> . Acesso em 04 de dez. 2006.

. PMSP/SP ETS-001: Camadas de reforço do subleito, sub-base e base mista de pavimento com agregado reciclado de resíduos sólidos da construção civil. Secretaria de Infra-estrutura Urbana, Especificação Técnica de Serviço, São Paulo, 2003.

. Notícias da PMSP: Prefeito assina decreto para reutilização de agregados reciclados (28/12/2006). São Paulo, 2006. Disponível em:

$<$ http://www.prefeitura.sp.gov.br/portal/a cidade/noticias/index.php?p=14052>. Acesso em: 02 de fev. 2007

RIBEIRO, F.; SERRA, N. G. S.; REZENDE, L. R.; GUIMARÃES, R. C. Utilização de entulho da construção civil em pavimentos flexíveis. In: REUNIÃO DE PAVIMENTAÇÃO URBANA, 11., Porto Alegre, 2002. Anais. Rio de Janeiro: ABPv, 2002. 1 CD-ROM.

SACHET, T.; RODRIGUES, R. M.; PRIETTO, P. D. M.; GONÇALVES, F. P. Controle tecnológico da reciclagem de bases granulares de pavimentos rodoviários através do ensaio DCP (Dynamic Cone Penetrometer). In: CONGRESSO BRASILEIRO DE MECÂNICA DOS SOLOS E ENGENHARIA DE FUNDAÇÕES, 13., Curitiba, 2006. Anais. São Paulo: ABMS, 2006. 1 CD-ROM. 
SCHNEIDER, D. M. Deposições irregulares de resíduos da construção civil na cidade de São Paulo. Dissertação (Mestrado) - Faculdade de Saúde Pública, Universidade de São Paulo. São Paulo, 2003.

SCHULZ, R.; HENDRICKS, F. Recycling of masonry rubble. Recycling of Demolished Concrete and Masonry. Report of Technical Committee - Demolition and Reuse of Concrete, 37. London: RILEM, 1992.

SHARP, R. W.; BOOKER, J. R. Shakedown of pavements under moving surface loads. Journal of Transportation Engineering, Reston, Virginia, n.110, p.1-14, 1984.

SIEKMEIER, J. A.; YOUNG, D.; BEBERG, D. Comparison of the Dynamic Cone Penetrometer with other tests during subgrade and granular base characterization in Minnesota. Nondestructive Testing of Pavements and Backcalculation of Moduli: Third Volume. ASTM STP 1375, S. D. Tayabji and E. O. Lukanen, American Society for Testing and Materials, West Conshohocken, Pennsylvania,

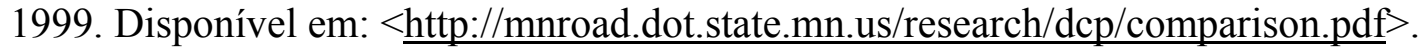
Acesso em: 19 de mai. 2006

SOBHAN, K.; MASHNAD, M. Fatigue damage in roller-compacted pavement foundation with recycled aggregate and waste plastic strips. Transportation Research Record, Washington, n.1798, p.8-16, 2002.

TRICHÊS, G.; CARDOSO, A. B. Avaliação da capacidade de aterros e subleito de rodovias utilizando o penetrômetro dinâmico e a viga Benkelman. Transporte em Transformação. Confederação Nacional do Transporte, Associação Nacional de Pesquisa e Ensino em Transporte. Número 6, 1999, p.35-49.

TRICHÊS, G.; KRYCKYJ, P. R. Aproveitamento de entulho da construção civil na pavimentação urbana. In: CONGRESSO BRASILEIRO DE GEOTECNIA AMBIENTAL, 4., São José dos Campos, 1999. Anais. São Paulo: ABMS, 1999, p.259-265.

VALLE, N. Utilização de solos residuais saprolíticos na pavimentação rodoviária em Santa Catarina. Dissertação (Mestrado). Programa de Pósgraduação em Engenharia Civil, Universidade Federal de Santa Catarina. Florianópolis, 1994.

VIEIRA, G. L.; DAL MOLIN, D. C. C.; LIMA, F. B. Resistência e durabilidade de concretos produzidos com agregados reciclados provenientes de resíduos de construção e demolição. Revista Engenharia Civil. Universidade do Minho. Número 19, 2004, p.5-18. Disponível em:

$<$ http://www.civil.uminho.pt/cec/revista/revista.htm>. Acesso em: 01 de ago. 2006 
VON STEIN, E. L. Chapter 20: Construction and demolition debris. The McGrawHill Recycling Handbook. Herbert F. Lund, McGraw-Hill Professional, 2nd edition, New York, 2000, 976p.

WERKMEISTER, S.; DAWSON, A. R.; WELLNER, F. Permanent deformation of granular materials and the shakedown concept. Transportation Research Record, Washington, n.1757, p.75-81, 2001.

YODER, E. J.; WITCZAK, M. W. Principles of pavement design. 2nd edition, New York, 1975, 711p.

ZORDAN, S. E. Metodologia de avaliação do potencial de reciclagem de resíduos. Tese (Doutorado). Escola Politécnica, Universidade de São Paulo. São Paulo, 2003. 
ANEXOS 


\section{Croqui USP Leste}

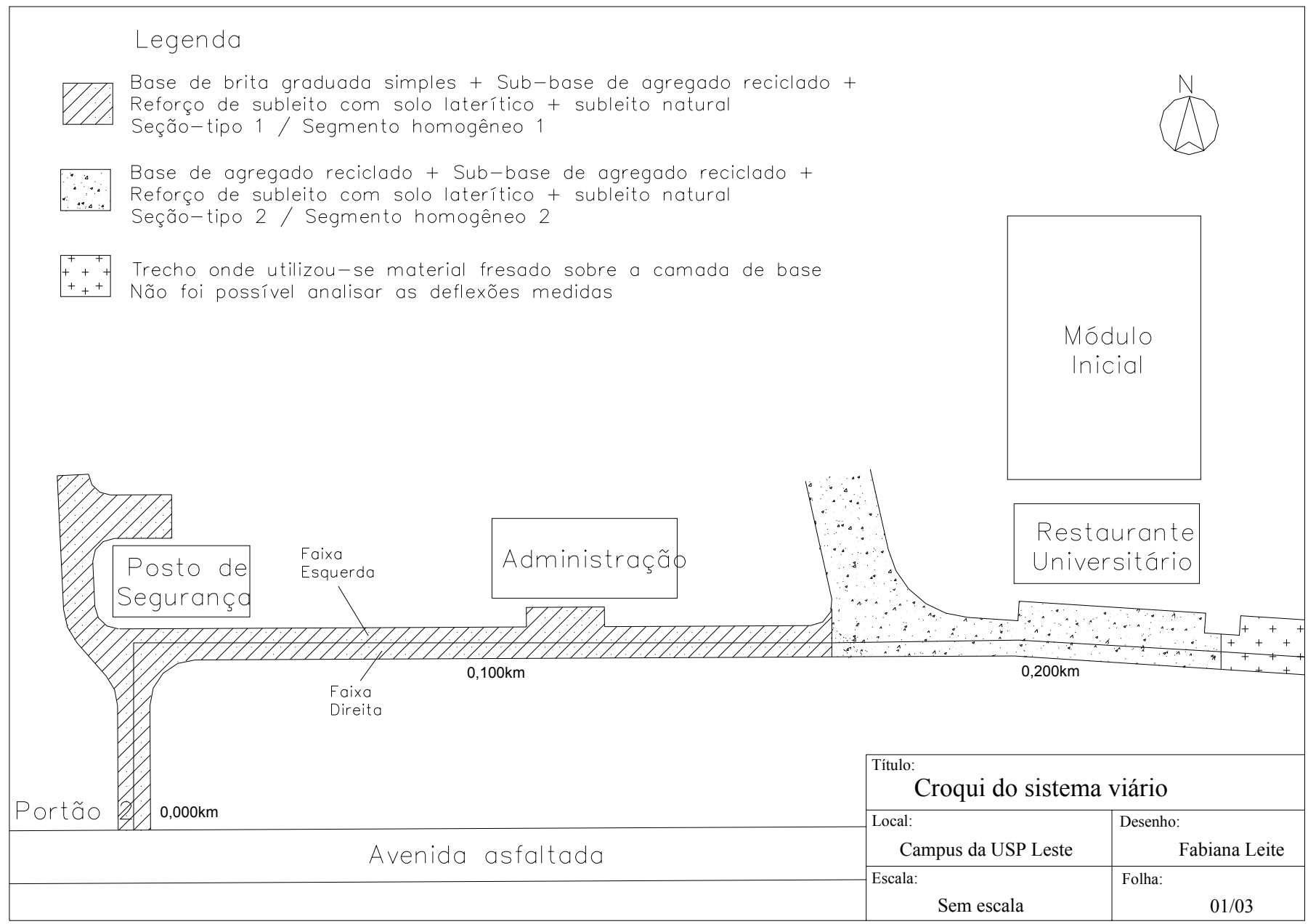




\section{Croqui USP Leste}

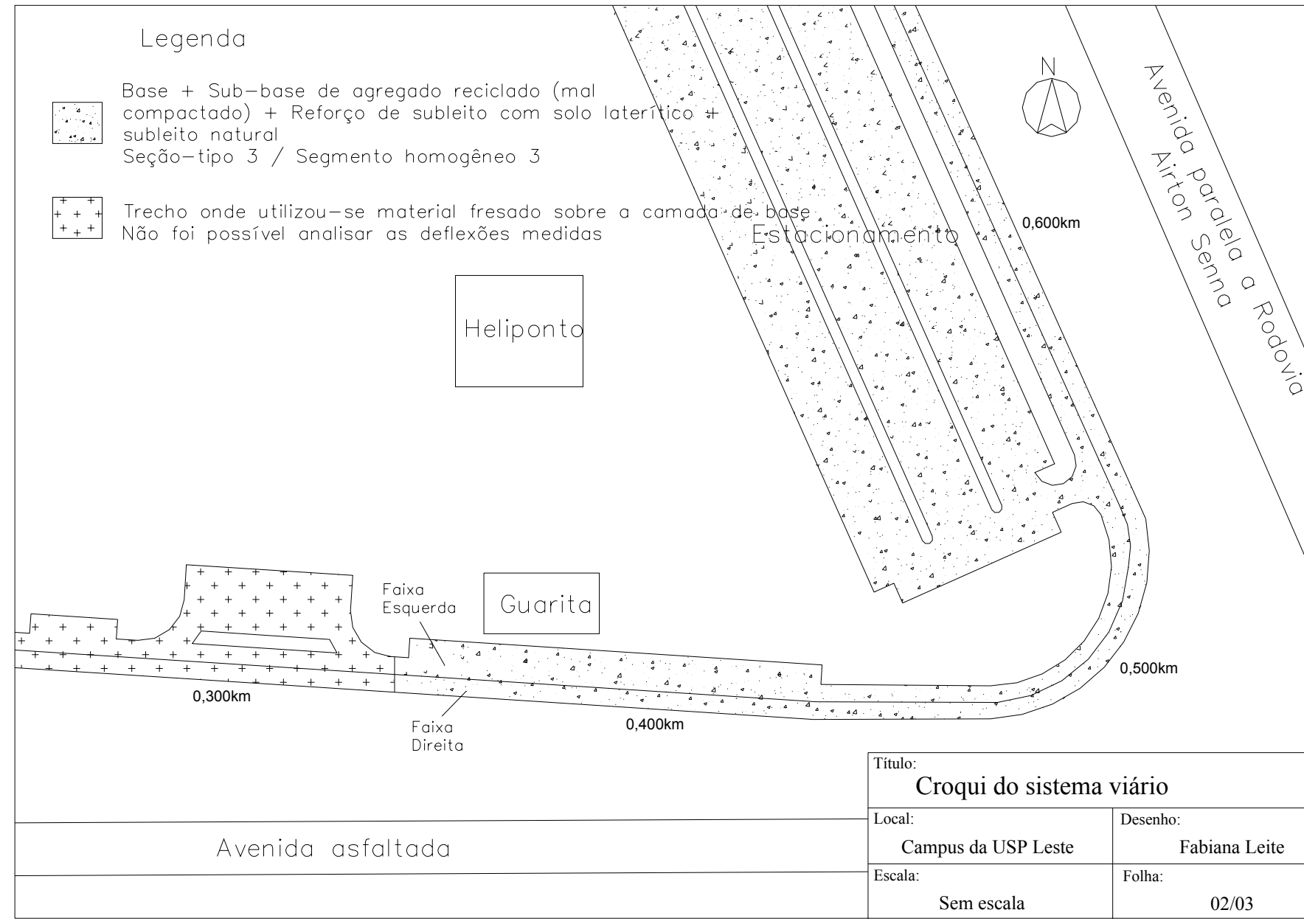




\section{Croqui USP Leste}

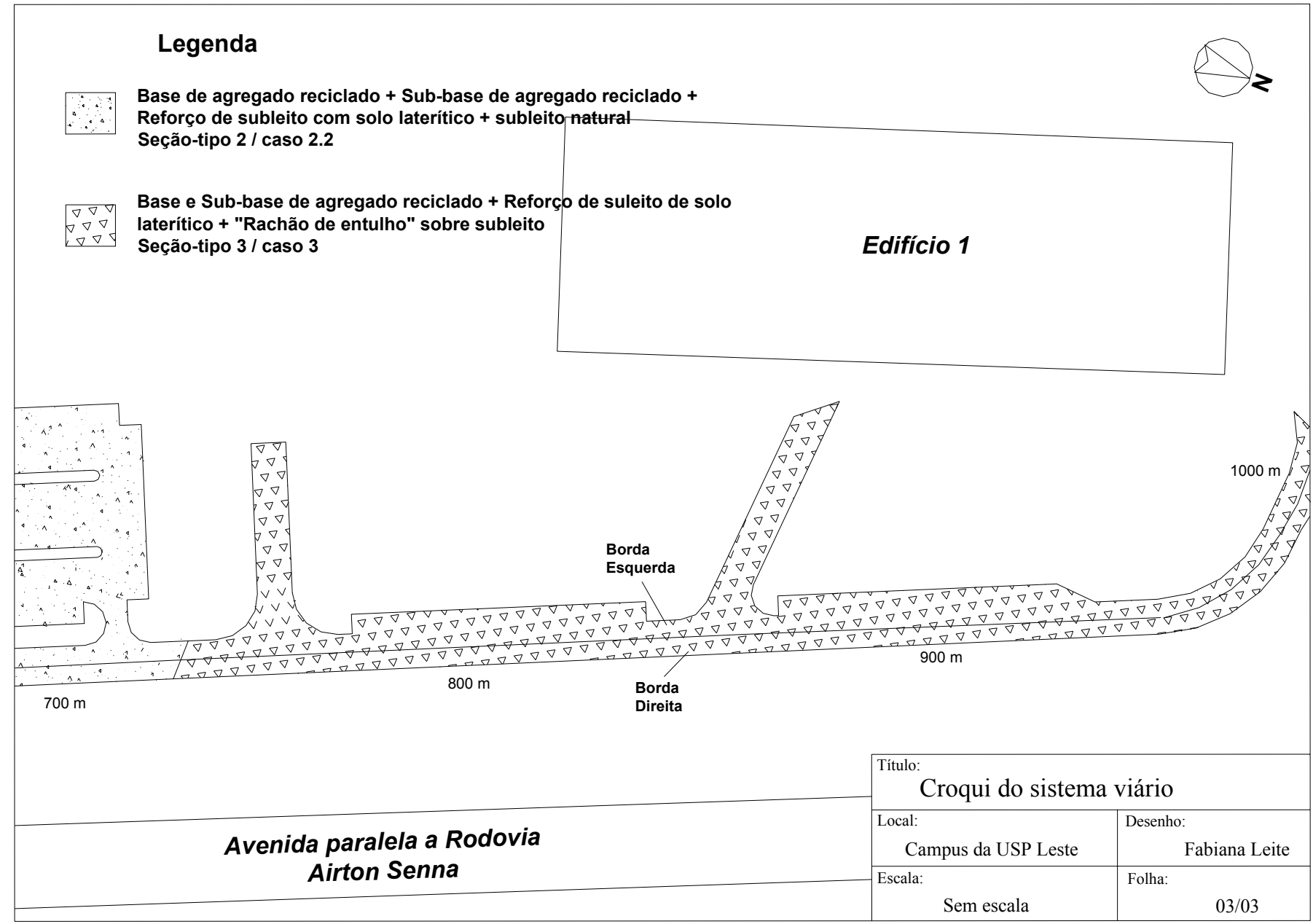




\section{Levantamento deflectométrico}

Data do levantamento: 27/11/2006

Rodovia: USP Leste

\begin{tabular}{|c|c|c|c|c|c|c|c|c|c|c|c|c|c|c|c|c|c|c|c|c|c|}
\hline \multirow{3}{*}{$\begin{array}{l}\text { Posição } \\
\text { [km] }\end{array}$} & \multicolumn{7}{|c|}{ Faixa Esquerda } & \multicolumn{7}{|c|}{ Eixo } & \multicolumn{7}{|c|}{ Faixa Direita } \\
\hline & \multicolumn{7}{|c|}{ Deflexões existentes $[0,01 \mathrm{~mm}]$} & \multicolumn{7}{|c|}{ Deflexões existentes $[0,01 \mathrm{~mm}]$} & \multicolumn{7}{|c|}{ Deflexões existentes $[0,01 \mathrm{~mm}]$} \\
\hline & $\mathrm{d}_{0}$ & $d_{20}$ & $d_{30}$ & $d_{45}$ & $d_{65}$ & $\mathrm{~d}_{90}$ & $d_{120}$ & $\mathrm{~d}_{0}$ & $\mathrm{~d}_{20}$ & $d_{30}$ & $d_{45}$ & $d_{65}$ & $\mathrm{~d}_{90}$ & $d_{120}$ & $\mathrm{~d}_{0}$ & $\mathrm{~d}_{20}$ & $\mathrm{~d}_{30}$ & $d_{45}$ & $d_{65}$ & $\mathrm{~d}_{90}$ & $d_{120}$ \\
\hline 0,000 & 64 & 48 & 37 & 26 & 14 & 9 & 5 & 71 & 48 & 35 & 23 & 14 & 9 & 7 & 59 & 45 & 36 & 28 & 18 & 13 & 9 \\
\hline 0,010 & - & - & - & - & - & - & - & 43 & 30 & 21 & 15 & 10 & 8 & 8 & - & - & - & - & - & - & - \\
\hline 0,020 & 44 & 30 & 23 & 17 & 13 & 9 & 5 & 45 & 31 & 22 & 15 & 10 & 8 & 8 & 37 & 28 & 23 & 18 & 12 & 8 & 8 \\
\hline 0,030 & 43 & 28 & 19 & 13 & 9 & 6 & 3 & 31 & 22 & 17 & 13 & 8 & 6 & 6 & 34 & 23 & 18 & 13 & 8 & 7 & 6 \\
\hline 0,040 & 56 & 36 & 25 & 17 & 11 & 7 & 3 & 37 & 27 & 20 & 14 & 9 & 7 & 6 & 41 & 29 & 22 & 15 & 9 & 7 & 5 \\
\hline 0,050 & 45 & 31 & 23 & 16 & 9 & 6 & 3 & 40 & 29 & 21 & 13 & 8 & 6 & 5 & 40 & 31 & 24 & 17 & 11 & 8 & 6 \\
\hline 0,060 & 47 & 34 & 25 & 18 & 11 & 7 & 4 & 35 & 25 & 19 & 14 & 9 & 6 & 6 & 51 & 40 & 32 & 24 & 16 & 12 & 10 \\
\hline 0,070 & 48 & 32 & 24 & 15 & 10 & 6 & 3 & 49 & 35 & 26 & 19 & 14 & 11 & 10 & 50 & 36 & 29 & 21 & 14 & 11 & 9 \\
\hline 0,080 & 45 & 32 & 25 & 18 & 13 & 9 & 5 & 46 & 34 & 26 & 19 & 14 & 10 & 9 & 45 & 34 & 28 & 20 & 13 & 9 & 7 \\
\hline 0,090 & 53 & 37 & 27 & 18 & 11 & 8 & 4 & 43 & 31 & 23 & 16 & 10 & 7 & 7 & 46 & 35 & 27 & 20 & 13 & 9 & 7 \\
\hline 0,100 & 49 & 37 & 29 & 22 & 14 & 7 & 5 & 50 & 36 & 25 & 17 & 10 & 8 & 6 & 44 & 32 & 26 & 19 & 12 & 9 & 7 \\
\hline 0,110 & 40 & 29 & 22 & 15 & 10 & 7 & 3 & 52 & 36 & 26 & 18 & 11 & 8 & 7 & 44 & 33 & 26 & 19 & 13 & 10 & 8 \\
\hline 0,120 & 45 & 30 & 22 & 15 & 11 & 7 & 4 & 38 & 26 & 20 & 15 & 10 & 9 & 8 & 41 & 32 & 26 & 20 & 15 & 11 & 10 \\
\hline 0,130 & 34 & 24 & 18 & 14 & 10 & 8 & 4 & 36 & 25 & 20 & 15 & 10 & 9 & 8 & 46 & 36 & 30 & 23 & 17 & 13 & 11 \\
\hline 0,140 & 36 & 24 & 18 & 14 & 11 & 8 & 4 & 34 & 26 & 21 & 17 & 12 & 10 & 9 & 56 & 44 & 37 & 28 & 20 & 16 & 13 \\
\hline 0,150 & 43 & 31 & 24 & 18 & 13 & 9 & 4 & 40 & 28 & 23 & 17 & 13 & 11 & 10 & 49 & 39 & 34 & 27 & 21 & 16 & 14 \\
\hline 0,160 & 49 & 34 & 25 & 19 & 14 & 10 & 5 & 34 & 26 & 22 & 18 & 14 & 12 & 10 & 64 & 51 & 42 & 33 & 24 & 18 & 15 \\
\hline 0,170 & 56 & 39 & 30 & 23 & 17 & 12 & 6 & 51 & 38 & 33 & 26 & 18 & 15 & 13 & 42 & 33 & 28 & 23 & 17 & 13 & 11 \\
\hline 0,180 & 39 & 29 & 25 & 19 & 15 & 11 & 5 & 53 & 38 & 32 & 25 & 20 & 16 & 13 & 32 & 24 & 22 & 18 & 13 & 11 & 9 \\
\hline 0,190 & 43 & 30 & 24 & 17 & 12 & 8 & 4 & 46 & 35 & 29 & 22 & 16 & 14 & 11 & 37 & 29 & 24 & 18 & 13 & 10 & 9 \\
\hline 0,200 & 46 & 34 & 26 & 18 & 11 & 8 & 4 & 46 & 29 & 22 & 15 & 11 & 9 & 7 & 50 & 38 & 31 & 23 & 15 & 11 & 9 \\
\hline 0,210 & 49 & 36 & 29 & 23 & 16 & 12 & 6 & 46 & 36 & 30 & 24 & 17 & 14 & 12 & 41 & 31 & 25 & 18 & 12 & 10 & 8 \\
\hline 0,220 & 58 & 42 & 33 & 25 & 18 & 12 & 6 & 49 & 35 & 28 & 21 & 15 & 11 & 9 & 46 & 36 & 30 & 22 & 16 & 12 & 10 \\
\hline 0,230 & 49 & 36 & 28 & 23 & 17 & 12 & 6 & 53 & 40 & 32 & 25 & 18 & 14 & 11 & 75 & 59 & 49 & 37 & 26 & 18 & 13 \\
\hline 0,240 & 56 & 44 & 37 & 30 & 23 & 15 & 8 & 58 & 45 & 37 & 28 & 20 & 15 & 13 & 77 & 60 & 48 & 35 & 24 & 17 & 13 \\
\hline 0,340 & 76 & 55 & 43 & 32 & 22 & 12 & 7 & 65 & 51 & 42 & 32 & 22 & 16 & 11 & 50 & 38 & 32 & 26 & 19 & 14 & 11 \\
\hline 0,350 & - & - & - & & - & - & & 38 & 30 & 24 & 19 & 14 & 10 & 9 & - & - & - & - & - & - & - \\
\hline 0,360 & 64 & 46 & 36 & 27 & 18 & 10 & 6 & 52 & 38 & 30 & 23 & 17 & 13 & 10 & 59 & 46 & 39 & 30 & 21 & 15 & 11 \\
\hline
\end{tabular}




\section{Levantamento deflectométrico}

Data do levantamento: 27/11/2006

Rodovia: USP Leste

\begin{tabular}{|c|c|c|c|c|c|c|c|c|c|c|c|c|c|c|c|c|c|c|c|c|c|}
\hline \multirow{3}{*}{$\begin{array}{l}\text { Posição } \\
\text { [km] }\end{array}$} & \multicolumn{7}{|c|}{ Faixa Esquerda } & \multicolumn{7}{|c|}{ Eixo } & \multicolumn{7}{|c|}{ Faixa Direita } \\
\hline & \multicolumn{7}{|c|}{ Deflexões existentes $[0,01 \mathrm{~mm}]$} & \multicolumn{7}{|c|}{ Deflexões existentes $[0,01 \mathrm{~mm}]$} & \multicolumn{7}{|c|}{ Deflexões existentes $[0,01 \mathrm{~mm}]$} \\
\hline & $\mathrm{d}_{0}$ & $\mathrm{~d}_{20}$ & $\mathrm{~d}_{30}$ & $\mathrm{~d}_{45}$ & $\mathrm{~d}_{65}$ & $\mathrm{~d}_{90}$ & $\mathrm{~d}_{120}$ & $\mathrm{~d}_{0}$ & $\mathrm{~d}_{20}$ & $d_{30}$ & $\mathrm{~d}_{45}$ & $d_{65}$ & $\mathrm{~d}_{90}$ & $d_{120}$ & $\mathrm{~d}_{0}$ & $\mathrm{~d}_{20}$ & $d_{30}$ & $\mathrm{~d}_{45}$ & $d_{65}$ & $\mathrm{~d}_{90}$ & $d_{120}$ \\
\hline 0,370 & - & - & - & - & - & - & - & 48 & 35 & 28 & 21 & 16 & 12 & 10 & - & - & - & - & - & - & - \\
\hline 0,380 & 58 & 38 & 27 & 20 & 14 & 10 & 5 & 55 & 36 & 29 & 23 & 15 & 13 & 10 & 64 & 51 & 43 & 34 & 23 & 17 & 13 \\
\hline 0,390 & - & - & - & - & - & - & - & 53 & 40 & 31 & 23 & 17 & 12 & 10 & - & - & - & - & - & - & - \\
\hline 0,400 & 56 & 37 & 27 & 20 & 15 & 10 & 5 & 47 & 35 & 28 & 22 & 16 & 13 & 11 & 63 & 48 & 38 & 28 & 18 & 12 & 9 \\
\hline 0,410 & - & - & - & - & - & - & - & 51 & 39 & 31 & 23 & 16 & 12 & 9 & - & - & - & - & - & - & - \\
\hline 0,420 & 46 & 29 & 20 & 14 & 10 & 7 & 4 & 46 & 31 & 24 & 17 & 11 & 9 & 7 & 56 & 45 & 38 & 30 & 21 & 15 & 12 \\
\hline 0,430 & - & - & - & - & - & - & - & 50 & 34 & 26 & 18 & 12 & 9 & 8 & - & - & - & - & - & - & - \\
\hline 0,440 & 57 & 40 & 29 & 20 & 13 & 8 & 4 & 63 & 46 & 36 & 25 & 16 & 11 & 9 & 72 & 52 & 40 & 30 & 20 & 14 & 11 \\
\hline 0,450 & - & - & - & - & - & - & - & 70 & 47 & 35 & 24 & 16 & 12 & 9 & - & - & - & - & - & - & - \\
\hline 0,460 & 78 & 52 & 36 & 25 & 17 & 11 & 7 & 62 & 44 & 33 & 23 & 16 & 12 & 10 & 76 & 59 & 49 & 38 & 25 & 17 & 12 \\
\hline 0,470 & - & - & - & - & - & - & - & 62 & 44 & 34 & 25 & 16 & 11 & 9 & - & - & - & - & - & - & - \\
\hline 0,480 & 83 & 58 & 41 & 28 & 18 & 11 & 6 & 83 & 58 & 44 & 30 & 18 & 13 & 10 & 92 & 66 & 53 & 40 & 26 & 18 & 13 \\
\hline 0,490 & - & - & - & - & - & - & - & 80 & 58 & 45 & 33 & 21 & 14 & 11 & - & - & - & - & - & - & - \\
\hline 0,500 & 62 & 41 & 29 & 20 & 13 & 8 & 5 & 65 & 45 & 33 & 22 & 14 & 10 & 8 & 61 & 43 & 34 & 24 & 14 & 9 & 7 \\
\hline 0,510 & - & - & - & - & - & - & & 66 & 49 & 37 & 26 & 16 & 11 & 9 & - & - & - & - & - & - & - \\
\hline 0,520 & 78 & 54 & 39 & 27 & 18 & 11 & 6 & 66 & 47 & 36 & 25 & 15 & 11 & 9 & 60 & 45 & 36 & 27 & 17 & 11 & 8 \\
\hline 0,530 & - & - & - & - & - & - & - & 62 & 48 & 38 & 27 & 17 & 12 & 9 & - & - & - & - & - & - & - \\
\hline 0,540 & 53 & 30 & 20 & 13 & 10 & 7 & 4 & 71 & 53 & 42 & 31 & 20 & 14 & 11 & 48 & 37 & 29 & 22 & 14 & 9 & 8 \\
\hline 0,550 & - & - & - & - & - & - & - & 63 & 46 & 35 & 26 & 18 & 13 & 10 & - & - & - & - & - & - & - \\
\hline 0,560 & 62 & 45 & 32 & 21 & 13 & 9 & 4 & 49 & 32 & 24 & 17 & 13 & 10 & 9 & 52 & 38 & 30 & 22 & 14 & 12 & 9 \\
\hline 0,570 & - & - & - & - & - & - & - & 55 & 37 & 26 & 16 & 10 & 8 & 7 & - & - & - & - & - & - & - \\
\hline 0,580 & 60 & 40 & 29 & 20 & 14 & 9 & 5 & 47 & 32 & 23 & 16 & 10 & 8 & 7 & 42 & 32 & 26 & 19 & 13 & 10 & 9 \\
\hline 0,590 & - & - & - & - & - & - & - & 48 & 33 & 24 & 17 & 11 & 9 & 8 & - & - & - & - & - & - & - \\
\hline 0,600 & 53 & 34 & 24 & 16 & 10 & 7 & 3 & 57 & 41 & 32 & 24 & 16 & 11 & 9 & 47 & 33 & 25 & 18 & 12 & 9 & 7 \\
\hline 0,610 & - & - & - & - & - & - & - & 47 & 33 & 24 & 16 & 10 & 8 & 7 & - & - & - & - & - & - & - \\
\hline 0,620 & 68 & 49 & 39 & 31 & 23 & 14 & 8 & 53 & 35 & 25 & 17 & 10 & 8 & 7 & 54 & 40 & 34 & 26 & 18 & 14 & 11 \\
\hline 0,630 & - & 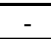 & - & - & - & - & & 75 & 51 & 38 & 27 & 18 & 13 & 11 & - & - & - & - & - & - & - \\
\hline 0,640 & 68 & 49 & 36 & 27 & 19 & 12 & 6 & 54 & 38 & 30 & 23 & 17 & 13 & 11 & 59 & 43 & 35 & 26 & 18 & 14 & 11 \\
\hline
\end{tabular}




\section{Levantamento deflectométrico}

Data do levantamento: 27/11/2006

Rodovia: USP Leste

\begin{tabular}{|c|c|c|c|c|c|c|c|c|c|c|c|c|c|c|c|c|c|c|c|c|c|}
\hline \multirow{3}{*}{$\begin{array}{l}\text { Posição } \\
\text { [km] }\end{array}$} & \multicolumn{7}{|c|}{ Faixa Esquerda } & \multicolumn{7}{|c|}{ Eixo } & \multicolumn{7}{|c|}{ Faixa Direita } \\
\hline & \multicolumn{7}{|c|}{ Deflexões existentes $[0,01 \mathrm{~mm}]$} & \multicolumn{7}{|c|}{ Deflexões existentes $[0,01 \mathrm{~mm}]$} & \multicolumn{7}{|c|}{ Deflexões existentes $[0,01 \mathrm{~mm}]$} \\
\hline & $\mathrm{d}_{0}$ & $\mathrm{~d}_{20}$ & $\mathrm{~d}_{30}$ & $\mathrm{~d}_{45}$ & $\mathrm{~d}_{65}$ & $\mathrm{~d}_{90}$ & $\mathrm{~d}_{120}$ & $\mathrm{~d}_{0}$ & $\mathrm{~d}_{20}$ & $\mathrm{~d}_{30}$ & $\mathrm{~d}_{45}$ & $d_{65}$ & $\mathrm{~d}_{90}$ & $d_{120}$ & $\mathrm{~d}_{0}$ & $d_{20}$ & $\mathrm{~d}_{30}$ & $\mathrm{~d}_{45}$ & $d_{65}$ & $\mathrm{~d}_{90}$ & $d_{120}$ \\
\hline 0,650 & - & - & - & - & - & - & - & 52 & 36 & 28 & 22 & 16 & 12 & 11 & - & - & - & - & - & - & - \\
\hline 0,660 & 60 & 39 & 28 & 22 & 17 & 11 & 6 & 45 & 30 & 23 & 17 & 12 & 10 & 8 & 33 & 24 & 19 & 14 & 9 & 7 & 6 \\
\hline 0,670 & - & - & - & - & - & - & - & 44 & 27 & 18 & 11 & 8 & 7 & 6 & - & - & - & - & - & - & - \\
\hline 0,680 & 53 & 30 & 19 & 12 & 8 & 6 & 3 & 47 & 27 & 17 & 10 & 7 & 6 & 6 & 60 & 39 & 27 & 17 & 10 & 8 & 7 \\
\hline 0,690 & - & - & - & - & - & - & - & 49 & 32 & 21 & 13 & 8 & 7 & 6 & - & - & - & - & - & - & - \\
\hline 0,700 & 68 & 42 & 28 & 18 & 11 & 8 & 4 & 47 & 32 & 23 & 15 & 9 & 7 & 6 & 49 & 37 & 29 & 21 & 14 & 10 & 8 \\
\hline 0,710 & - & - & - & - & - & - & - & 71 & 47 & 36 & 26 & 17 & 12 & 9 & - & - & - & - & - & - & - \\
\hline 0,720 & 77 & 50 & 33 & 21 & 11 & 7 & 4 & 34 & 23 & 18 & 12 & 8 & 6 & 5 & 56 & 36 & 26 & 16 & 10 & 8 & 7 \\
\hline 0,730 & - & - & - & - & - & - & - & 54 & 38 & 25 & 15 & 9 & 7 & 5 & - & - & - & - & - & - & - \\
\hline 0,740 & 48 & 30 & 20 & 13 & 8 & 6 & 3 & 47 & 30 & 22 & 14 & 8 & 6 & 6 & 49 & 33 & 22 & 14 & 9 & 7 & 6 \\
\hline 0,750 & - & - & - & - & - & - & - & 47 & 30 & 21 & 13 & 8 & 6 & 5 & - & - & - & - & - & - & - \\
\hline 0,760 & 64 & 37 & 25 & 15 & 9 & 6 & 3 & 46 & 27 & 18 & 11 & 6 & 4 & 4 & 55 & 31 & 22 & 14 & 8 & 5 & 5 \\
\hline 0,770 & - & - & - & - & - & - & - & 54 & 32 & 21 & 12 & 6 & 5 & 4 & - & - & - & - & - & - & - \\
\hline 0,780 & 66 & 38 & 23 & 13 & 8 & 5 & 3 & 45 & 28 & 19 & 11 & 6 & 4 & 4 & 41 & 28 & 21 & 14 & 9 & 6 & 5 \\
\hline 0,790 & - & - & - & - & - & - & - & 40 & 26 & 18 & 11 & 6 & 5 & 4 & - & - & - & - & - & - & - \\
\hline 0,800 & 54 & 33 & 23 & 15 & 9 & 6 & 3 & 43 & 26 & 19 & 13 & 9 & 7 & 6 & 47 & 32 & 24 & 16 & 10 & 8 & 6 \\
\hline 0,810 & - & - & - & - & - & - & - & 43 & 26 & 18 & 11 & 7 & 6 & 5 & - & - & - & - & - & - & - \\
\hline 0,820 & 54 & 32 & 20 & 13 & 8 & 5 & 3 & 44 & 29 & 21 & 14 & 9 & 7 & 6 & 43 & 31 & 24 & 18 & 13 & 9 & 8 \\
\hline 0,830 & - & - & - & - & - & - & - & 34 & 22 & 15 & 10 & 7 & 6 & 5 & - & - & - & - & - & - & - \\
\hline 0,840 & 49 & 29 & 20 & 14 & 10 & 7 & 4 & 36 & 23 & 17 & 10 & 7 & 6 & 5 & 39 & 27 & 21 & 15 & 10 & 8 & 6 \\
\hline 0,850 & - & - & - & - & - & - & - & 42 & 26 & 18 & 12 & 9 & 7 & 6 & - & - & - & - & - & - & - \\
\hline 0,860 & 48 & 30 & 20 & 13 & 9 & 6 & 3 & 34 & 24 & 19 & 13 & 8 & 6 & 5 & 38 & 25 & 20 & 15 & 11 & 8 & 7 \\
\hline 0,870 & - & - & - & - & - & - & - & 38 & 26 & 19 & 13 & 8 & 6 & 5 & - & - & - & - & - & - & - \\
\hline 0,880 & 46 & 29 & 21 & 14 & 9 & 6 & 3 & 31 & 22 & 16 & 12 & 8 & 6 & 5 & 37 & 26 & 21 & 16 & 13 & 11 & 9 \\
\hline 0,890 & - & - & - & - & - & - & - & 34 & 23 & 17 & 12 & 8 & 6 & 5 & - & - & - & - & - & - & - \\
\hline 0,900 & 58 & 36 & 24 & 15 & 8 & 5 & 3 & 25 & 19 & 15 & 11 & 8 & 6 & 5 & 41 & 31 & 25 & 19 & 14 & 11 & 9 \\
\hline 0,910 & - & - & - & - & - & - & - & 41 & 27 & 21 & 14 & 9 & 7 & 6 & - & - & - & - & - & - & - \\
\hline 0,920 & 25 & 17 & 14 & 10 & 7 & 5 & 3 & 38 & 26 & 19 & 13 & 8 & 6 & 6 & 31 & 22 & 18 & 14 & 10 & 9 & 7 \\
\hline
\end{tabular}


Levantamento deflectométrico

Data do levantamento: 27/11/2006

Rodovia: USP Leste

\begin{tabular}{|c|c|c|c|c|c|c|c|c|c|c|c|c|c|c|c|c|c|c|c|c|c|}
\hline \multirow{3}{*}{$\begin{array}{l}\text { Posição } \\
{[\mathrm{km}]}\end{array}$} & \multicolumn{7}{|c|}{ Faixa Esquerda } & \multicolumn{7}{|c|}{ Eixo } & \multicolumn{7}{|c|}{ Faixa Direita } \\
\hline & \multicolumn{7}{|c|}{ Deflexões existentes $[0,01 \mathrm{~mm}]$} & \multicolumn{7}{|c|}{ Deflexões existentes $[0,01 \mathrm{~mm}]$} & \multicolumn{7}{|c|}{ Deflexões existentes $[0,01 \mathrm{~mm}]$} \\
\hline & $\mathrm{d}_{0}$ & $d_{20}$ & $d_{30}$ & $\mathrm{~d}_{45}$ & $d_{65}$ & $\mathrm{~d}_{90}$ & $d_{120}$ & $\mathrm{~d}_{0}$ & $\mathrm{~d}_{20}$ & $\mathrm{~d}_{30}$ & $\mathrm{~d}_{45}$ & $d_{65}$ & $\mathrm{~d}_{90}$ & $d_{120}$ & $\mathrm{~d}_{0}$ & $\mathrm{~d}_{20}$ & $\mathrm{~d}_{30}$ & $d_{45}$ & $d_{65}$ & $\mathrm{~d}_{90}$ & $d_{120}$ \\
\hline 0,930 & - & - & - & - & - & - & - & 26 & 18 & 14 & 10 & 8 & 7 & 6 & - & - & - & - & - & - & - \\
\hline 0,940 & 28 & 23 & 20 & 16 & 12 & 8 & 4 & 22 & 17 & 13 & 10 & 8 & 6 & 6 & 30 & 22 & 19 & 15 & 11 & 9 & 8 \\
\hline 0,950 & - & - & - & - & - & - & - & 24 & 18 & 15 & 11 & 8 & 6 & 6 & - & - & - & - & - & - & - \\
\hline 0,960 & 37 & 28 & 22 & 17 & 12 & 8 & 4 & 32 & 24 & 20 & 14 & 10 & 8 & 6 & 23 & 17 & 14 & 12 & 9 & 7 & 5 \\
\hline 0,970 & - & - & - & - & - & - & - & 25 & 19 & 16 & 12 & 9 & 7 & 6 & - & - & - & - & - & - & - \\
\hline 0,980 & 43 & 25 & 16 & 11 & 8 & 6 & 3 & 41 & 25 & 19 & 12 & 8 & 6 & 6 & 47 & 26 & 17 & 12 & 7 & 6 & 5 \\
\hline 0,990 & - & - & - & - & - & - & - & 42 & 27 & 19 & 14 & 10 & 8 & 7 & - & - & - & - & - & - & - \\
\hline 1,000 & 34 & 25 & 19 & 14 & 11 & 7 & 4 & 21 & 13 & 10 & 7 & 5 & 5 & 5 & 26 & 15 & 12 & 9 & 7 & 6 & 6 \\
\hline 1,010 & - & - & - & - & - & - & - & 48 & 35 & 28 & 23 & 17 & 14 & 11 & - & - & - & - & - & - & - \\
\hline 1,020 & 45 & 34 & 28 & 23 & 18 & 18 & 7 & 32 & 23 & 20 & 18 & 15 & 13 & 11 & 39 & 29 & 25 & 21 & 17 & 14 & 13 \\
\hline
\end{tabular}




\section{Retroanálise: Eixo}

Data do levantamento: 27/11/2006

Rodovia: USP Leste

\begin{tabular}{|c|c|c|c|c|c|c|c|c|c|c|c|c|c|c|c|c|c|c|c|c|c|c|c|}
\hline \multirow{3}{*}{$\begin{array}{c}\text { Posição } \\
{[\mathrm{km}]}\end{array}$} & \multicolumn{9}{|c|}{ Módulos de Resiliência [MPa] } & \multirow{2}{*}{\multicolumn{7}{|c|}{ Deflexões existentes $[0,01 \mathrm{~mm}]$}} & \multirow{2}{*}{\multicolumn{7}{|c|}{ Deflexões calculadas $[0,01 \mathrm{~mm}]$}} \\
\hline & \multicolumn{2}{|c|}{ Revestimento } & \multicolumn{2}{|c|}{ Base } & \multicolumn{2}{|c|}{\begin{tabular}{|l|} 
Sub-base \\
\end{tabular}} & \multicolumn{2}{|c|}{ Reforço de Sub } & \multirow{2}{*}{\begin{tabular}{|c|} 
Subleito \\
$\mathrm{M}_{\mathrm{R}}[\mathrm{MPa}]$ \\
\end{tabular}} & & & & & & & & & & & & & & \\
\hline & $\mathrm{M}_{\mathrm{R}}[\mathrm{MPa}]$ & \begin{tabular}{c|} 
Esp. \\
{$[\mathrm{mm}]$}
\end{tabular} & $\mathrm{M}_{\mathrm{R}}[\mathrm{MPa}]$ & $\begin{array}{c}\text { Esp. } \\
{[\mathrm{mm}]}\end{array}$ & $\mathrm{M}_{\mathrm{R}}[\mathrm{MPa}]$ & $\begin{array}{c}\text { Esp. } \\
{[\mathrm{mm}]}\end{array}$ & $\mathrm{M}_{\mathrm{R}}[\mathrm{MPa}]$ & $\begin{array}{c}\text { Esp. } \\
{[\mathrm{mm}]}\end{array}$ & & $\mathrm{d}_{0}$ & $\mathrm{~d}_{20}$ & $\mathrm{~d}_{30}$ & $\mathrm{~d}_{45}$ & $d_{65}$ & $\mathrm{~d}_{90}$ & $d_{120}$ & $d_{0}$ & $\mathrm{~d}_{20}$ & $\mathrm{~d}_{30}$ & $\mathrm{~d}_{45}$ & $d_{65}$ & $\mathrm{~d}_{90}$ & $d_{120}$ \\
\hline 0,000 & 2000 & 80 & 200 & 100 & 180 & 150 & 120 & 200 & 120 & 71 & 48 & 35 & 23 & 14 & 9 & 7 & 70 & 46 & 34 & 23 & 15 & 11 & 8 \\
\hline 0,010 & 3000 & 100 & 350 & 100 & 350 & 150 & 200 & 200 & 150 & 43 & 30 & 21 & 15 & 10 & 8 & 8 & 41 & 29 & 22 & 17 & 12 & 9 & 7 \\
\hline 0,020 & 3000 & 80 & 350 & 100 & 350 & 150 & 180 & 200 & 150 & 45 & 31 & 22 & 15 & 10 & 8 & 8 & 45 & 31 & 23 & 17 & 12 & 9 & 7 \\
\hline 0,030 & 3500 & 100 & 350 & 150 & 350 & 150 & 250 & 200 & 200 & 31 & 22 & 17 & 13 & 8 & 6 & 6 & 34 & 24 & 18 & 13 & 9 & 7 & 6 \\
\hline 0,040 & 3000 & 100 & 350 & 150 & 350 & 150 & 220 & 200 & 180 & 37 & 27 & 20 & 14 & 9 & 7 & 6 & 37 & 26 & 20 & 14 & 10 & 7 & 6 \\
\hline 0,050 & 3000 & 100 & 350 & 100 & 300 & 150 & 200 & 200 & 180 & 40 & 29 & 21 & 13 & 8 & 6 & 5 & 39 & 28 & 21 & 15 & 10 & 7 & 6 \\
\hline 0,060 & 3000 & 100 & 350 & 100 & 300 & 150 & 250 & 200 & 200 & 35 & 25 & 19 & 14 & 9 & 6 & 6 & 36 & 25 & 19 & 13 & 9 & 7 & 6 \\
\hline 0,070 & 3000 & 100 & 350 & 100 & 300 & 150 & 180 & 200 & 120 & 49 & 35 & 26 & 19 & 14 & 11 & 10 & 46 & 34 & 27 & 20 & 16 & 12 & 11 \\
\hline 0,080 & 3000 & 100 & 350 & 100 & 350 & 150 & 180 & 200 & 120 & 46 & 34 & 26 & 19 & 14 & 10 & 9 & 46 & 34 & 27 & 20 & 16 & 12 & 11 \\
\hline 0,090 & 3000 & 100 & 350 & 100 & 300 & 150 & 150 & 200 & 150 & 43 & 31 & 23 & 16 & 10 & 7 & 7 & 43 & 31 & 24 & 18 & 13 & 9 & 7 \\
\hline 0,100 & 3000 & 80 & 300 & 100 & 250 & 150 & 200 & 200 & 150 & 50 & 36 & 25 & 17 & 10 & 8 & 6 & 49 & 34 & 25 & 17 & 12 & 9 & 7 \\
\hline 0,110 & 3000 & 80 & 300 & 100 & 250 & 150 & 200 & 200 & 150 & 52 & 36 & 26 & 18 & 11 & 8 & 7 & 49 & 34 & 25 & 17 & 12 & 9 & 7 \\
\hline 0,120 & 3000 & 100 & 350 & 150 & 350 & 150 & 220 & 200 & 180 & 38 & 26 & 20 & 15 & 10 & 9 & 8 & 37 & 26 & 20 & 14 & 10 & 7 & 6 \\
\hline 0,130 & 3000 & 100 & 350 & 150 & 350 & 150 & 220 & 200 & 180 & 36 & 25 & 20 & 15 & 10 & 9 & 8 & 37 & 26 & 20 & 14 & 10 & 7 & 6 \\
\hline 0,140 & 3000 & 100 & 350 & 150 & 350 & 150 & 200 & 200 & 150 & 34 & 26 & 21 & 17 & 12 & 10 & 9 & 34 & 24 & 18 & 13 & 9 & 7 & 6 \\
\hline 0,150 & 3000 & 100 & 350 & 100 & 350 & 150 & 200 & 200 & 150 & 40 & 28 & 23 & 17 & 13 & 11 & 10 & 41 & 29 & 22 & 17 & 12 & 9 & 7 \\
\hline 0,160 & 3500 & 100 & 350 & 200 & 350 & 250 & 250 & 200 & 120 & 34 & 26 & 22 & 18 & 14 & 12 & 10 & 39 & 28 & 23 & 18 & 14 & 11 & 9 \\
\hline 0,170 & 3000 & 100 & 350 & 100 & 300 & 150 & 150 & 200 & 100 & 51 & 38 & 33 & 26 & 18 & 15 & 13 & 50 & 38 & 31 & 24 & 18 & 14 & 10 \\
\hline 0,180 & 3000 & 100 & 350 & 100 & 300 & 150 & 150 & 200 & 90 & 53 & 38 & 32 & 25 & 20 & 16 & 13 & 53 & 40 & 33 & 26 & 20 & 16 & 12 \\
\hline 0,190 & 3000 & 100 & 350 & 100 & 300 & 150 & 180 & 200 & 120 & 46 & 35 & 29 & 22 & 16 & 14 & 11 & 46 & 34 & 27 & 20 & 16 & 12 & 11 \\
\hline 0,200 & 3000 & 80 & 350 & 100 & 350 & 150 & 180 & 200 & 150 & 46 & 29 & 22 & 15 & 11 & 9 & 7 & 45 & 31 & 23 & 17 & 12 & 9 & 7 \\
\hline 0,210 & 3000 & 100 & 350 & 100 & 300 & 150 & 180 & 200 & 120 & 46 & 36 & 30 & 24 & 17 & 14 & 12 & 46 & 34 & 27 & 20 & 16 & 12 & 11 \\
\hline 0,220 & 3000 & 80 & 300 & 100 & 250 & 150 & 200 & 200 & 150 & 49 & 35 & 28 & 21 & 15 & 11 & 9 & 49 & 34 & 25 & 17 & 12 & 9 & 7 \\
\hline 0,230 & 3000 & 100 & 350 & 100 & 300 & 150 & 150 & 200 & 90 & 53 & 40 & 32 & 25 & 18 & 14 & 11 & 53 & 40 & 33 & 26 & 20 & 16 & 12 \\
\hline 0,240 & 3000 & 100 & 250 & 100 & 200 & 150 & 150 & 200 & 90 & 58 & 45 & 37 & 28 & 20 & 15 & 13 & 58 & 44 & 36 & 27 & 20 & 15 & 11 \\
\hline 0,340 & 3000 & 100 & 220 & 150 & 200 & 150 & 120 & 200 & 80 & 65 & 51 & 42 & 32 & 22 & 16 & 11 & 64 & 50 & 41 & 31 & 24 & 17 & 13 \\
\hline 0,350 & 3500 & 100 & 350 & 200 & 350 & 250 & 250 & 200 & 120 & 38 & 30 & 24 & 19 & 14 & 10 & 9 & 39 & 28 & 23 & 18 & 14 & 11 & 9 \\
\hline 0,360 & 3000 & 100 & 300 & 150 & 300 & 150 & 150 & 200 & 100 & 52 & 38 & 30 & 23 & 17 & 13 & 10 & 51 & 38 & 31 & 24 & 18 & 14 & 10 \\
\hline 0,370 & 3000 & 100 & 350 & 150 & 300 & 150 & 180 & 200 & 120 & 48 & 35 & 28 & 21 & 16 & 12 & 10 & 46 & 34 & 27 & 20 & 16 & 12 & 11 \\
\hline
\end{tabular}




\section{Retroanálise: Eixo}

Data do levantamento: 27/11/2006

Rodovia: USP Leste

\begin{tabular}{|c|c|c|c|c|c|c|c|c|c|c|c|c|c|c|c|c|c|c|c|c|c|c|c|}
\hline \multirow{3}{*}{$\begin{array}{c}\text { Posição } \\
{[\mathrm{km}]}\end{array}$} & \multicolumn{9}{|c|}{ Módulos de Resiliência [MPa] } & \multirow{2}{*}{\multicolumn{7}{|c|}{ Deflexões existentes $[0,01 \mathrm{~mm}]$}} & \multirow{2}{*}{\multicolumn{7}{|c|}{ Deflexões calculadas $[0,01 \mathrm{~mm}]$}} \\
\hline & \multicolumn{2}{|c|}{ Revestimento } & \multicolumn{2}{|c|}{ Base } & \multicolumn{2}{|c|}{$\begin{array}{l}\text { Sub-base } \\
\end{array}$} & \multicolumn{2}{|c|}{ Reforço de Sub } & \multirow{2}{*}{$\begin{array}{c}\text { Subleito } \\
\mathrm{M}_{\mathrm{R}}[\mathrm{MPa}]\end{array}$} & & & & & & & & & & & & & & \\
\hline & $\mathrm{M}_{\mathrm{R}}[\mathrm{MPa}]$ & $\begin{array}{c}\text { Esp. } \\
{[\mathrm{mm}]}\end{array}$ & $\mathrm{M}_{\mathrm{R}}[\mathrm{MPa}]$ & $\begin{array}{c}\text { Esp. } \\
{[\mathrm{mm}]}\end{array}$ & $\mathrm{M}_{\mathrm{R}}[\mathrm{MPa}]$ & $\begin{array}{c}\text { Esp. } \\
{[\mathrm{mm}]}\end{array}$ & $\mathrm{M}_{\mathrm{R}}[\mathrm{MPa}]$ & \begin{tabular}{|c} 
Esp. \\
{$[\mathrm{mm}]$}
\end{tabular} & & $\mathrm{d}_{0}$ & $\mathrm{~d}_{20}$ & $d_{30}$ & $d_{45}$ & $d_{65}$ & $\mathrm{~d}_{90}$ & $d_{120}$ & $\mathrm{~d}_{0}$ & $\mathrm{~d}_{20}$ & $d_{30}$ & $\mathrm{~d}_{45}$ & $d_{65}$ & $\mathrm{~d}_{90}$ & $d_{120}$ \\
\hline 0,380 & 3000 & 80 & 350 & 150 & 350 & 150 & 150 & 200 & 100 & 55 & 36 & 29 & 23 & 15 & 13 & 10 & 53 & 38 & 31 & 24 & 18 & 14 & 10 \\
\hline 0,390 & 3000 & 80 & 350 & 150 & 350 & 150 & 150 & 200 & 100 & 53 & 40 & 31 & 23 & 17 & 12 & 10 & 53 & 38 & 31 & 24 & 18 & 14 & 10 \\
\hline 0,400 & 3000 & 100 & 300 & 150 & 250 & 150 & 180 & 200 & 120 & 47 & 35 & 28 & 22 & 16 & 13 & 11 & 48 & 35 & 28 & 21 & 16 & 12 & 9 \\
\hline 0,410 & 3000 & 100 & 300 & 150 & 250 & 150 & 150 & 200 & 110 & 51 & 39 & 31 & 23 & 16 & 12 & 9 & 51 & 38 & 30 & 23 & 17 & 12 & 9 \\
\hline 0,420 & 3000 & 80 & 350 & 100 & 350 & 150 & 180 & 200 & 150 & 46 & 31 & 24 & 17 & 11 & 9 & 7 & 45 & 31 & 23 & 17 & 12 & 9 & 7 \\
\hline 0,430 & 3000 & 100 & 250 & 150 & 250 & 150 & 180 & 200 & 140 & 50 & 34 & 26 & 18 & 12 & 9 & 8 & 48 & 34 & 26 & 19 & 13 & 10 & 8 \\
\hline 0,440 & 3000 & 100 & 150 & 150 & 150 & 150 & 120 & 200 & 120 & 63 & 46 & 36 & 25 & 16 & 11 & 9 & 63 & 46 & 36 & 26 & 16 & 11 & 9 \\
\hline 0,450 & 2500 & 80 & 200 & 150 & 160 & 150 & 140 & 200 & 110 & 70 & 47 & 35 & 24 & 16 & 12 & 9 & 70 & 47 & 35 & 25 & 17 & 12 & 9 \\
\hline 0,460 & 2500 & 80 & 250 & 150 & 250 & 150 & 180 & 200 & 100 & 62 & 44 & 33 & 23 & 16 & 12 & 10 & 61 & 42 & 32 & 24 & 18 & 14 & 10 \\
\hline 0,470 & 3000 & 100 & 200 & 150 & 150 & 150 & 140 & 200 & 110 & 62 & 44 & 34 & 25 & 16 & 11 & 9 & 60 & 44 & 35 & 25 & 17 & 12 & 9 \\
\hline 0,480 & 2500 & 80 & 120 & 150 & 120 & 150 & 130 & 200 & 100 & 83 & 58 & 44 & 30 & 18 & 13 & 10 & 85 & 58 & 43 & 29 & 19 & 13 & 10 \\
\hline 0,490 & 2000 & 100 & 120 & 150 & 100 & 150 & 110 & 200 & 100 & 80 & 58 & 45 & 33 & 21 & 14 & 11 & 81 & 58 & 45 & 30 & 20 & 14 & 10 \\
\hline 0,500 & 2500 & 80 & 200 & 150 & 200 & 150 & 140 & 200 & 120 & 65 & 45 & 33 & 22 & 14 & 10 & 8 & 65 & 44 & 33 & 22 & 16 & 11 & 8 \\
\hline 0,510 & 2000 & 100 & 200 & 150 & 150 & 150 & 140 & 200 & 110 & 66 & 49 & 37 & 26 & 16 & 11 & 9 & 67 & 47 & 36 & 25 & 17 & 12 & 9 \\
\hline 0,520 & 2000 & 100 & 200 & 150 & 150 & 150 & 140 & 200 & 110 & 66 & 47 & 36 & 25 & 15 & 11 & 9 & 67 & 47 & 36 & 25 & 17 & 12 & 9 \\
\hline 0,530 & 3000 & 100 & 150 & 150 & 150 & 150 & 140 & 200 & 110 & 62 & 48 & 38 & 27 & 17 & 12 & 9 & 63 & 47 & 36 & 26 & 18 & 12 & 9 \\
\hline 0,540 & 2500 & 100 & 150 & 150 & 150 & 150 & 120 & 200 & 90 & 71 & 53 & 42 & 31 & 20 & 14 & 11 & 71 & 53 & 41 & 30 & 21 & 15 & 11 \\
\hline 0,550 & 2500 & 100 & 200 & 150 & 150 & 150 & 140 & 200 & 100 & 63 & 46 & 35 & 26 & 18 & 13 & 10 & 61 & 46 & 36 & 27 & 19 & 14 & 10 \\
\hline 0,560 & 2500 & 80 & 350 & 200 & 350 & 200 & 200 & 200 & 110 & 49 & 32 & 24 & 17 & 13 & 10 & 9 & 47 & 32 & 25 & 19 & 15 & 12 & 9 \\
\hline 0,570 & 2500 & 80 & 250 & 150 & 250 & 150 & 200 & 200 & 150 & 55 & 37 & 26 & 16 & 10 & 8 & 7 & 53 & 35 & 25 & 17 & 12 & 9 & 7 \\
\hline 0,580 & 3000 & 100 & 250 & 150 & 250 & 150 & 180 & 200 & 150 & 47 & 32 & 23 & 16 & 10 & 8 & 7 & 47 & 33 & 26 & 18 & 13 & 9 & 7 \\
\hline 0,590 & 3000 & 100 & 250 & 150 & 250 & 150 & 180 & 200 & 150 & 48 & 33 & 24 & 17 & 11 & 9 & 8 & 47 & 33 & 26 & 18 & 13 & 9 & 7 \\
\hline 0,600 & 2000 & 100 & 250 & 150 & 200 & 150 & 180 & 200 & 110 & 57 & 41 & 32 & 24 & 16 & 11 & 9 & 57 & 40 & 31 & 23 & 16 & 12 & 9 \\
\hline 0,610 & 3000 & 100 & 250 & 150 & 250 & 150 & 180 & 200 & 150 & 47 & 33 & 24 & 16 & 10 & 8 & 7 & 47 & 33 & 26 & 18 & 13 & 9 & 7 \\
\hline 0,620 & 2000 & 80 & 250 & 150 & 250 & 200 & 180 & 200 & 150 & 53 & 35 & 25 & 17 & 10 & 8 & 7 & 54 & 35 & 25 & 17 & 12 & 9 & 7 \\
\hline 0,630 & 2000 & 80 & 200 & 150 & 150 & 200 & 140 & 250 & 100 & 75 & 51 & 38 & 27 & 18 & 13 & 11 & 73 & 49 & 37 & 26 & 18 & 13 & 10 \\
\hline 0,640 & 2000 & 100 & 300 & 150 & 250 & 200 & 200 & 250 & 100 & 54 & 38 & 30 & 23 & 17 & 13 & 11 & 52 & 37 & 29 & 22 & 17 & 13 & 10 \\
\hline 0,650 & 2500 & 100 & 300 & 150 & 250 & 200 & 200 & 250 & 100 & 52 & 36 & 28 & 22 & 16 & 12 & 11 & 50 & 36 & 29 & 22 & 17 & 13 & 10 \\
\hline 0,660 & 3000 & 80 & 350 & 150 & 350 & 150 & 180 & 200 & 150 & 45 & 30 & 23 & 17 & 12 & 10 & 8 & 45 & 31 & 23 & 17 & 12 & 9 & 7 \\
\hline
\end{tabular}




\section{Retroanálise: Eixo}

Data do levantamento: 27/11/2006

Rodovia: USP Leste

\begin{tabular}{|c|c|c|c|c|c|c|c|c|c|c|c|c|c|c|c|c|c|c|c|c|c|c|c|}
\hline \multirow{3}{*}{$\begin{array}{c}\text { Posição } \\
{[\mathrm{km}]}\end{array}$} & \multicolumn{9}{|c|}{ Módulos de Resiliência [MPa] } & \multirow{2}{*}{\multicolumn{7}{|c|}{ Deflexões existentes $[0,01 \mathrm{~mm}]$}} & \multirow{2}{*}{\multicolumn{7}{|c|}{ Deflexões calculadas $[0,01 \mathrm{~mm}]$}} \\
\hline & \multicolumn{2}{|c|}{ Revestimento } & \multicolumn{2}{|c|}{ Base } & \multicolumn{2}{|c|}{ Sub-base } & \multicolumn{2}{|c|}{ Reforço de Sub } & \multirow{2}{*}{$\begin{array}{c}\text { Subleito } \\
M_{R}[\mathrm{MPa}]\end{array}$} & & & & & & & & & & & & & & \\
\hline & $\mathrm{M}_{\mathrm{R}}[\mathrm{MPa}]$ & $\begin{array}{c}\text { Esp. } \\
{[\mathrm{mm}]}\end{array}$ & $\mathrm{M}_{\mathrm{R}}[\mathrm{MPa}]$ & $\begin{array}{c}\text { Esp. } \\
{[\mathrm{mm}]}\end{array}$ & $\mathrm{M}_{\mathrm{R}}[\mathrm{MPa}]$ & $\begin{array}{c}\text { Esp. } \\
{[\mathrm{mm}]}\end{array}$ & $\mathrm{M}_{\mathrm{R}}[\mathrm{MPa}]$ & \begin{tabular}{|c|} 
Esp. \\
{$[\mathrm{mm}]$}
\end{tabular} & & $\mathrm{d}_{0}$ & $\mathrm{~d}_{20}$ & $d_{30}$ & $d_{45}$ & $d_{65}$ & $\mathrm{~d}_{90}$ & $d_{120}$ & $\mathrm{~d}_{0}$ & $d_{20}$ & $\mathrm{~d}_{30}$ & $\mathrm{~d}_{45}$ & $d_{65}$ & $\mathrm{~d}_{90}$ & $d_{120}$ \\
\hline 0,670 & 2000 & 80 & 350 & 100 & 350 & 150 & 350 & 250 & 250 & 44 & 27 & 18 & 11 & 8 & 7 & 6 & 42 & 26 & 18 & 13 & 9 & 7 & 6 \\
\hline 0,680 & 2000 & 80 & 350 & 100 & 350 & 150 & 350 & 250 & 250 & 47 & 27 & 17 & 10 & 7 & 6 & 6 & 42 & 26 & 18 & 13 & 9 & 7 & 6 \\
\hline 0,690 & 1500 & 80 & 300 & 100 & 300 & 200 & 250 & 250 & 180 & 49 & 32 & 21 & 13 & 8 & 7 & 6 & 48 & 28 & 19 & 13 & 9 & 7 & 6 \\
\hline 0,700 & 2500 & 80 & 250 & 100 & 250 & 200 & 250 & 250 & 180 & 47 & 32 & 23 & 15 & 9 & 7 & 6 & 47 & 30 & 21 & 14 & 9 & 7 & 6 \\
\hline 0,710 & 2000 & 80 & 200 & 150 & 150 & 150 & 140 & 200 & 110 & 71 & 47 & 36 & 26 & 17 & 12 & 9 & 72 & 47 & 36 & 25 & 17 & 12 & 9 \\
\hline 0,720 & 3000 & 100 & 350 & 150 & 350 & 200 & 200 & 250 & 200 & 34 & 23 & 18 & 12 & 8 & 6 & 5 & 35 & 24 & 18 & 13 & 9 & 7 & 5 \\
\hline 0,730 & 2000 & 80 & 180 & 150 & 150 & 200 & 200 & 250 & 200 & 54 & 38 & 25 & 15 & 9 & 7 & 5 & 54 & 36 & 25 & 16 & 9 & 7 & 5 \\
\hline 0,740 & 2000 & 100 & 250 & 150 & 250 & 200 & 200 & 250 & 180 & 47 & 30 & 22 & 14 & 8 & 6 & 6 & 46 & 30 & 22 & 15 & 10 & 7 & 6 \\
\hline 0,750 & 2500 & 100 & 200 & 150 & 200 & 200 & 200 & 250 & 200 & 47 & 30 & 21 & 13 & 8 & 6 & 5 & 47 & 31 & 23 & 15 & 9 & 6 & 5 \\
\hline 0,760 & 2500 & 100 & 250 & 150 & 250 & 200 & 200 & 250 & 220 & 46 & 27 & 18 & 11 & 6 & 4 & 4 & 42 & 27 & 20 & 13 & 9 & 6 & 4 \\
\hline 0,770 & 2000 & 80 & 200 & 150 & 200 & 200 & 200 & 250 & 220 & 54 & 32 & 21 & 12 & 6 & 5 & 4 & 55 & 33 & 22 & 13 & 8 & 6 & 4 \\
\hline 0,780 & 2500 & 100 & 200 & 150 & 200 & 200 & 200 & 250 & 210 & 45 & 28 & 19 & 11 & 6 & 4 & 4 & 46 & 30 & 22 & 14 & 9 & 6 & 4 \\
\hline 0,790 & 2500 & 100 & 250 & 150 & 250 & 200 & 200 & 250 & 220 & 40 & 26 & 18 & 11 & 6 & 5 & 4 & 42 & 27 & 20 & 13 & 9 & 6 & 4 \\
\hline 0,800 & 2500 & 100 & 250 & 150 & 250 & 200 & 200 & 250 & 220 & 43 & 26 & 19 & 13 & 9 & 7 & 6 & 42 & 27 & 20 & 13 & 9 & 6 & 4 \\
\hline 0,810 & 2000 & 80 & 350 & 150 & 350 & 150 & 250 & 250 & 180 & 43 & 26 & 18 & 11 & 7 & 6 & 5 & 42 & 26 & 18 & 13 & 9 & 7 & 6 \\
\hline 0,820 & 2000 & 80 & 350 & 150 & 350 & 150 & 250 & 250 & 180 & 44 & 29 & 21 & 14 & 9 & 7 & 6 & 42 & 26 & 18 & 13 & 9 & 7 & 6 \\
\hline 0,830 & 3000 & 100 & 400 & 200 & 350 & 250 & 200 & 200 & 200 & 34 & 22 & 15 & 10 & 7 & 6 & 5 & 33 & 22 & 17 & 12 & 9 & 7 & 5 \\
\hline 0,840 & 3000 & 100 & 400 & 200 & 350 & 250 & 200 & 200 & 200 & 36 & 23 & 17 & 10 & 7 & 6 & 5 & 33 & 22 & 17 & 12 & 9 & 7 & 5 \\
\hline 0,850 & 2000 & 80 & 350 & 100 & 350 & 200 & 250 & 200 & 180 & 42 & 26 & 18 & 12 & 9 & 7 & 6 & 42 & 26 & 18 & 13 & 9 & 7 & 6 \\
\hline 0,860 & 3000 & 100 & 400 & 200 & 350 & 250 & 200 & 200 & 200 & 34 & 24 & 19 & 13 & 8 & 6 & 5 & 33 & 22 & 17 & 12 & 9 & 7 & 5 \\
\hline 0,870 & 2500 & 100 & 350 & 150 & 350 & 150 & 200 & 200 & 200 & 38 & 26 & 19 & 13 & 8 & 6 & 5 & 37 & 25 & 19 & 13 & 9 & 7 & 5 \\
\hline 0,880 & 3000 & 100 & 400 & 200 & 350 & 250 & 200 & 200 & 200 & 31 & 22 & 16 & 12 & 8 & 6 & 5 & 33 & 22 & 17 & 12 & 9 & 7 & 5 \\
\hline 0,890 & 3000 & 100 & 400 & 200 & 350 & 250 & 200 & 200 & 200 & 34 & 23 & 17 & 12 & 8 & 6 & 5 & 33 & 22 & 17 & 12 & 9 & 7 & 5 \\
\hline 0,900 & 3000 & 100 & 400 & 250 & 350 & 250 & 200 & 250 & 200 & 25 & 19 & 15 & 11 & 8 & 6 & 5 & 32 & 22 & 17 & 12 & 9 & 7 & 5 \\
\hline 0,910 & 2000 & 80 & 350 & 100 & 350 & 200 & 250 & 200 & 180 & 41 & 27 & 21 & 14 & 9 & 7 & 6 & 42 & 26 & 18 & 13 & 9 & 7 & 6 \\
\hline 0,920 & 2500 & 100 & 350 & 150 & 350 & 150 & 200 & 200 & 200 & 38 & 26 & 19 & 13 & 8 & 6 & 6 & 37 & 25 & 19 & 13 & 9 & 7 & 5 \\
\hline 0,930 & 3000 & 100 & 400 & 250 & 350 & 250 & 200 & 250 & 200 & 26 & 18 & 14 & 10 & 8 & 7 & 6 & 32 & 22 & 17 & 12 & 9 & 7 & 5 \\
\hline 0,940 & 3000 & 100 & 400 & 250 & 350 & 250 & 200 & 250 & 200 & 22 & 17 & 13 & 10 & 8 & 6 & 6 & 32 & 22 & 17 & 12 & 9 & 7 & 5 \\
\hline 0,950 & 3000 & 100 & 400 & 250 & 350 & 250 & 200 & 250 & 200 & 24 & 18 & 15 & 11 & 8 & 6 & 6 & 32 & 22 & 17 & 12 & 9 & 7 & 5 \\
\hline
\end{tabular}




\section{Retroanálise: Eixo}

Data do levantamento: 27/11/2006

Rodovia: USP Leste

\begin{tabular}{|c|c|c|c|c|c|c|c|c|c|c|c|c|c|c|c|c|c|c|c|c|c|c|c|}
\hline \multirow{3}{*}{$\begin{array}{c}\text { Posição } \\
{[\mathrm{km}]}\end{array}$} & \multicolumn{9}{|c|}{ Módulos de Resiliência [MPa] } & \multirow{2}{*}{\multicolumn{7}{|c|}{ Deflexões existentes $[0,01 \mathrm{~mm}]$}} & \multirow{2}{*}{\multicolumn{7}{|c|}{ Deflexões calculadas $[0,01 \mathrm{~mm}]$}} \\
\hline & \multicolumn{2}{|c|}{ Revestimento } & \multicolumn{2}{|c|}{ Base } & \multicolumn{2}{|c|}{\begin{tabular}{|l|} 
Sub-base \\
\end{tabular}} & \multicolumn{2}{|c|}{ Reforço de Sub } & \multirow{2}{*}{$\begin{array}{c}\text { Subleito } \\
M_{R}[\mathrm{MPa}]\end{array}$} & & & & & & & & & & & & & & \\
\hline & $\overline{\mathrm{M}_{\mathrm{R}}[\mathrm{MPa}]}$ & $\begin{array}{c}\text { Esp. } \\
{[\mathrm{mm}]}\end{array}$ & $\overline{\mathrm{M}_{\mathrm{R}}[\mathrm{MPa}]}$ & $\begin{array}{l}\text { Esp. } \\
{[\mathrm{mm}]}\end{array}$ & $\overline{\mathrm{M}_{\mathrm{R}}[\mathrm{MPa}]}$ & $\begin{array}{c}\text { Esp. } \\
{[\mathrm{mm}]}\end{array}$ & $\mathrm{M}_{\mathrm{R}}[\mathrm{MPa}]$ & \begin{tabular}{|c} 
Esp. \\
{$[\mathrm{mm}]$}
\end{tabular} & & $\mathrm{d}_{0}$ & $\mathrm{~d}_{20}$ & $\mathrm{~d}_{30}$ & $d_{45}$ & $d_{65}$ & $\mathrm{~d}_{90}$ & $d_{120}$ & $\mathrm{~d}_{0}$ & $d_{20}$ & $d_{30}$ & $\mathrm{~d}_{45}$ & $d_{65}$ & $\mathrm{~d}_{90}$ & $d_{120}$ \\
\hline 0,960 & 3000 & 100 & 350 & 150 & 350 & 200 & 200 & 200 & 200 & 32 & 24 & 20 & 14 & 10 & 8 & 6 & 34 & 24 & 19 & 14 & 10 & 7 & 5 \\
\hline 0,970 & 3000 & 100 & 400 & 250 & 350 & 250 & 200 & 250 & 200 & 25 & 19 & 16 & 12 & 9 & 7 & 6 & 32 & 22 & 17 & 12 & 9 & 7 & 5 \\
\hline 0,980 & 2000 & 80 & 350 & 100 & 350 & 200 & 250 & 200 & 180 & 41 & 25 & 19 & 12 & 8 & 6 & 6 & 32 & 22 & 17 & 12 & 9 & 7 & 5 \\
\hline 0,990 & 2000 & 80 & 350 & 100 & 350 & 200 & 250 & 200 & 180 & 42 & 27 & 19 & 14 & 10 & 8 & 7 & 32 & 22 & 17 & 12 & 9 & 7 & 5 \\
\hline 1,000 & 3000 & 100 & 400 & 250 & 350 & 250 & 200 & 250 & 200 & 21 & 13 & 10 & 7 & 5 & 5 & 5 & 32 & 22 & 17 & 12 & 9 & 7 & 5 \\
\hline 1,010 & 3000 & 100 & 350 & 100 & 300 & 150 & 180 & 200 & 120 & 48 & 35 & 28 & 23 & 17 & 14 & 11 & 46 & 34 & 27 & 20 & 16 & 12 & 11 \\
\hline 1,020 & 4000 & 100 & 400 & 200 & 350 & 250 & 300 & 250 & 110 & 32 & 23 & 20 & 18 & 15 & 13 & 11 & 37 & 28 & 22 & 18 & 15 & 12 & 10 \\
\hline
\end{tabular}




\section{Retroanálise: Faixa Direita}

Data do levantamento: 27/11/2006

Rodovia: USP Leste

\begin{tabular}{|c|c|c|c|c|c|c|c|c|c|c|c|c|c|c|c|c|c|c|c|c|c|c|c|}
\hline \multirow{3}{*}{$\begin{array}{c}\text { Segmento } \\
\text { homogêneo }\end{array}$} & \multicolumn{9}{|c|}{ Módulos de Resiliência [MPa] } & \multirow{2}{*}{\multicolumn{7}{|c|}{ Deflexões existentes $[0,01 \mathrm{~mm}]$}} & \multirow{2}{*}{\multicolumn{7}{|c|}{ Deflexões calculadas $[0,01 \mathrm{~mm}]$}} \\
\hline & \multicolumn{2}{|c|}{ Revestimento } & \multicolumn{2}{|c|}{ Base } & \multicolumn{2}{|c|}{ Sub-base } & \multicolumn{2}{|c|}{ Reforço de Sub } & \multirow{2}{*}{$\begin{array}{c}\text { Subleito } \\
\mathrm{M}_{\mathrm{R}}[\mathrm{MPa}]\end{array}$} & & & & & & & & & & & & & & \\
\hline & $\mathrm{M}_{\mathrm{R}}[\mathrm{MPa}]$ & $\begin{array}{c}\text { Esp. } \\
{[\mathrm{mm}]}\end{array}$ & $\mathrm{M}_{\mathrm{R}}[\mathrm{MPa}]$ & $\begin{array}{c}\text { Esp. } \\
{[\mathrm{mm}]}\end{array}$ & $\mathrm{M}_{\mathrm{R}}[\mathrm{MPa}]$ & $\begin{array}{c}\text { Esp. } \\
{[\mathrm{mm}]}\end{array}$ & $\overline{\mathrm{M}_{\mathrm{R}}[\mathrm{MPa}]}$ & $\begin{array}{c}\text { Esp. } \\
{[\mathrm{mm}]}\end{array}$ & & $\mathrm{d}_{0}$ & $d_{20}$ & $d_{30}$ & $d_{45}$ & $d_{65}$ & $\mathrm{~d}_{90}$ & $d_{120}$ & $\mathrm{~d}_{0}$ & $\mathrm{~d}_{20}$ & $d_{30}$ & $d_{45}$ & $d_{65}$ & $\mathrm{~d}_{90}$ & $d_{120}$ \\
\hline 1,000 & 3000 & 100 & 00 & 100 & 50 & 150 & 200 & 200 & 12( & 50 & 38 & 31 & 23 & 15 & 11 & 9 & 50 & 37 & 30 & 22 & 16 & 11 & 9 \\
\hline 2,000 & 3000 & 100 & 300 & 100 & 250 & 150 & 200 & 200 & 110 & 50 & 39 & 32 & 24 & 17 & 13 & 10 & 51 & 38 & 30 & 23 & 17 & 13 & 10 \\
\hline 3,000 & 2500 & 100 & 200 & 150 & 200 & 150 & 170 & 200 & 110 & 58 & 43 & 34 & 25 & 17 & 12 & 9 & 59 & 43 & 33 & 24 & 17 & 12 & 9 \\
\hline 4,000 & 3000 & 100 & 350 & 150 & 300 & 200 & 200 & 200 & 190 & 39 & 26 & 20 & 15 & 10 & 8 & 7 & 39 & 27 & 21 & 15 & 10 & 8 & 6 \\
\hline
\end{tabular}

\section{Retroanálise: Faixa Esquerda}

Data do levantamento: 27/11/2006

Rodovia: USP Leste

\begin{tabular}{|c|c|c|c|c|c|c|c|c|c|c|c|c|c|c|c|c|c|c|c|c|c|c|c|}
\hline \multirow{3}{*}{$\begin{array}{l}\text { Segmento } \\
\text { homogêneo }\end{array}$} & \multicolumn{9}{|c|}{ Módulos de Resiliência [MPa] } & \multirow{2}{*}{\multicolumn{7}{|c|}{ Deflexões existentes $[0,01 \mathrm{~mm}]$}} & \multirow{2}{*}{\multicolumn{7}{|c|}{ Deflexões calculadas $[0,01 \mathrm{~mm}]$}} \\
\hline & \multicolumn{2}{|c|}{ Revestimento } & \multicolumn{2}{|c|}{ Base } & \multicolumn{2}{|c|}{ Sub-base } & \multicolumn{2}{|c|}{ Reforço de Sub } & \multirow{2}{*}{$\begin{array}{c}\text { Subleito } \\
\mathrm{M}_{\mathrm{R}}[\mathrm{MPa}]\end{array}$} & & & & & & & & & & & & & & \\
\hline & $\mathrm{M}_{\mathrm{R}}[\mathrm{MPa}]$ & $\begin{array}{c}\text { Esp. } \\
{[\mathrm{mm}]}\end{array}$ & $\mathrm{M}_{\mathrm{R}}[\mathrm{MPa}]$ & $\begin{array}{c}\text { Esp. } \\
{[\mathrm{mm}]}\end{array}$ & $\mathrm{M}_{\mathrm{R}}[\mathrm{MPa}]$ & $\begin{array}{c}\text { Esp. } \\
{[\mathrm{mm}]}\end{array}$ & $\mathrm{M}_{\mathrm{R}}[\mathrm{MPa}]$ & $\begin{array}{c}\text { Esp. } \\
{[\mathrm{mm}]}\end{array}$ & & $\mathrm{d}_{0}$ & $d_{20}$ & $d_{30}$ & $d_{45}$ & $d_{65}$ & $\mathrm{~d}_{90}$ & $d_{120}$ & $\mathrm{~d}_{0}$ & $d_{20}$ & $d_{30}$ & $d_{45}$ & $d_{65}$ & $\mathrm{~d}_{90}$ & $d_{120}$ \\
\hline 1,000 & 3000 & 100 & 200 & 100 & 180 & 150 & 150 & 200 & 180 & 52 & 36 & 27 & 19 & 12 & 8 & 4 & 51 & 36 & 27 & 18 & 12 & 8 & 5 \\
\hline 2,000 & 3000 & 100 & 350 & 100 & 250 & 150 & 100 & 200 & 150 & 49 & 36 & 29 & 22 & 16 & 11 & 6 & 49 & 36 & 28 & 20 & 14 & 10 & 7 \\
\hline 3,000 & 2500 & 100 & 180 & 150 & 150 & 200 & 100 & 250 & 150 & 64 & 43 & 31 & 22 & 15 & 9 & 5 & 62 & 43 & 32 & 22 & 15 & 9 & 6 \\
\hline 4,000 & 2500 & 100 & 200 & 150 & 200 & 200 & 200 & 250 & 210 & 46 & 30 & 21 & 14 & 10 & 7 & 4 & 46 & 30 & 22 & 14 & 9 & 6 & 4 \\
\hline
\end{tabular}

